九州大学学術情報リポジトリ

Kyushu University Institutional Repository

\title{
Upper Cretaceous Ammonites of California Part III
}

Matsumoto, Tatsuro

Department of Geology, Kyushu University

Popenoe, W, P

Department of Geology, University of California

https://doi.org/10.5109/1546813

出版情報: 九州大學理學部紀要：Series D, Geology. Special vol. 2, pp.1-204，1960-01-25. Faculty of Science, Kyushu University

バージョン :

権利関係 : 
Mem. Fac. Sci., Kyushu Univ., Ser. D, Geology, Special Volume II, pp. 1-204, text-figs. 1-20, pls. 1-2, January 1960

\title{
Upper Cretaceous Ammonites of California
}

\section{Part III*}

\author{
By \\ Tatsuro Matsumoto \\ With Notes on Stratigraphy of the Redding area and the Santa Ana Mountains
}

$\mathrm{By}$

Tatsuro MATsumoto and W. P. Popenoe**

\section{Notes on Stratigraphy}

Reliable records of localities are indispensable for paleontologic as well as stratigraphic studies of ammonites. A considerable number of papers have hitherto been published in which local stratigraphy is described. Although specific names of ammonites may not have been thoroughly listed in these previous papers, the stratigraphic subdivisions established in them can be referred to. Yet I think that probably more than ten years persistent field work will be needed for satisfactory study of the Upper Cretaceous ammonites of California. Since the period of my stay in California was limited, I could not, of course, fulfill this requirement. But, owing to kind help of the professors and many other friends, I visited several places to examine stratigraphic sections and have got some new acquisition. The descriptive notes of local stratigraphy in this chapter depend principally on already published records, but may include some new information as well as my own views. I will record the names of the kind friends who have allowed me to describe in this paper new information which they supplied me. Regarding the stratigraphy of the Redding area, Shasta County and the Santa Ana Mountains I depend very much on Dr. W. P. PopenoE's published and also unpublished work. Therefore joint authorship is taken for Notes on Stratigraphy of these two areas: articles (2) and (9) in the following description.

\section{Hornbrook-Yreka area, Siskiyou County, northern California and Jackson County, southwest Oregon}

Patches of the Upper Cretaceous outcrops are distributed in a belt roughly running northwest from the Hornbrook-Yreka area in northern California, along the valley of Bear Creek in southwest Oregon. This general area covers several

* Received, October 20, 1959. Continued from Part II (Mem. Fac. Sci., Kyushu Univ., Ser. D, Geol., Special Vol. I, pp. 1-172, text-figs. 1-80; pls. 1-41, November 1959).

** Department of Geology, University of California, Los Angeles. 
ammonite localities which have been well known since the date of GABB (1864, 1869) and ANDERson (1902). They are, for instance, "Forty-nine Mine, near Phoenix, Oregon" (CAS. 445, UC. A-169), "SMITH ranch [=FiTCH ranch], 2.5 miles southwest of Phoenix, Oregon (CAS. 445A, UC. A-170), "Dark Hollow, on old Pioneer road, 4 miles southwest of Phoenix, Oregon" (CAS. 444, CAS. 455), "Rocky Gulch, southwest of Hornbrook, Siskiyou County, California" (CAS. 444A), and "0.5 mile south of Hornbrook, Siskiyou County, California" (CAS. 444B). These place names do not necessarily indicate a precise locality for a restricted thickness of the stratigraphic sequence, but may include, as in the first and the second examples, rocks of a wide stratigraphic range.

The only reliable stratigraphic description founded on careful field work is that of PECK, ImLAY, and PoPEnOE (1956). They have proposed the name of Hornbrook formation for the Upper Cretaceous beds near Henley and Hornbrook, subdividing them into Members I-VI. Fossils do not occur uniformly throughout, but are restricted to certain particular parts. In the total thickness of $815( \pm 15)$ meters [2673 $( \pm 50)$ feet] along the measured section, Units 4 and 5 of Member I, Unit 8 of Member II, Unit 14 of Member V, and Unit 15 of Member VI are fossiliferous. According to the authors, the first three among these five units contain Subprionocyclus sp., Collignoniceras (?) sp., and other Turonian species, while the last two contain Metaplacenticeras pacificum (Sмiтн), Desmophyllites sp., Eupachydiscus cf. perplicatus (WhITEAVES) [=E. haradai (JIMBO)], and other species of Campanian aspect. The specimens at my disposal from older collections from this area can be sorted into two groups which approximately correspond to those given above. The species from CAS. 444, for instance, show the Campanian assemblage, while those from CAS. 444A show the Upper Turonian one (see the specific names of my identification in the list of localities). The same statement can be applied to specimens of relatively recent collections. The localities SOC. K-234, CIT. 1042, and CIT. 1044 are best referable to Member I, as judged from M. V. KIRK's and W. P. PopenoE's information. From them came Subprionocyclus neptuni (GEINITZ) or S. cf. neptuni, that indicates the Upper Turonian. In connection with this fact, the record of "Collignoniceras (?) sp." in Member II above Subprionocyclus sp. of Member I in the list of PECK et al. (1956). is rather unusual, but I have not inspected the actual specimens of their "Collignoniceras (?) sp." I would suggest that this might be Subprionocyclus branneri (ANDERSON). From the locality SOC. K-235, which is probably referred to the upper part of Member V, KIRK obtained the ammonites of Upper Campanian aspect, Anapachydiscus deccannensis (STOLICZKA), Pachydiscus sp., and Metaplacenticeras pacificum (SмITH). IMLAY showed me the specimens from USGS. Mes. loc. 25218, which belongs to Unit 14 of Member $\mathrm{V}$ of the Hornbrook formation (see PECK et al., 1956, p. 1980). I have identified them to Desmophyllites diphylloides (ForBes), Pachydiscus cf. subcompressus MATsumoto, Metaplacenticeras pacificum (SмiтH), Gaudryceras sp. and Tetragonites (Saghalinites) sp. The assemblage suggests the higher part of the Campanian. 
PECK et al. (1956, p. 1978-1980) gave interesting remarks on the ammonite localities in Jackson County, southwest Oregon. They have pointed out that there is a Cenomanian part in addition to the Turonian. In fact, Mantelliceras sp. of IMLAY's identification suggests Lower Cenomanian, Acanthoceras sp. cf. "Ammonites turneri WHITE (non SoWERBY)" [=Acanthoceras whitei MATSUмото] and Calycoceras stoliczkai Collignon Upper Cenomanian, Plesiovascoceras californicum (ANDERSON) Lower Turonian, Collignoniceras woollgari (MANTELL) [=C. bakeri (ANDERsoN)] Middle Turonian, and Subprionocyclus neptuni (GEINITZ) [=Oregoniceras siskiyouense (ANDERSON), O. knighteni (ANDERSON)] and $S$. normalis (ANDERSON) Upper Turonian. But the relative stratigraphic position in Oregon of these and other species, including Tragodesmoceras ashlandicum (ANDERSON) and Subprionocyclus branneri (ANDERSON), have not yet been well established in the field.

The Lower Senonian seems to be represented by barren beds in the Hornbrook formation. PECK et al. (1956) consider that a disconformity may exist between Members II and III. But I should like to note that an ammonite from loc. UC. A-173, RICHARDSON ranch, 4 miles north of Montague is referable to Kossmaticeras sp. aff. $K$. japonicum MATSUмото, which strongly suggests a horizon near the junction of Coniacian and Santonian. From the same or a nearby locality are known Kossmaticeras (?) klamathone (ANDERSON) [resembling $K$. pachystoma (Kossmat)] and Prionocycloceras crenulatum (ANDERSON), which most probably indicate Coniacian.

From all the available evidence it can be concluded that the HornbrookYreka area of California and its extension in Jackson County, Oregon are one of the important Cretaceous areas for the succession of ammonites from Lower Cenomanian to Upper Campanian. The succession can only be established, however, by compilation of records from several areas, because the Cretaceous outcrops are scattered and because no single section shows the complete sequence. More or less sandy facies of relatively shallow sea environments prevailed in the Upper Cretaceous sediments of this area, as is shown by the lithology and the faunal assemblage (Trigonia-Calva-Cucullaea). The succession of species belonging to the families Acanthoceratidae and Collignoniceratidae should be examined. The results, if satisfactorily obtained, would be important for international correlation.

I know that Dr. IMLAY, Dr. JoNEs, and their associates are now active in the geological and paleontological work of this region. Therefore, I have not gone deeply into the relationship of the ammonites and the stratigraphy of this area.

\section{Redding area, northeast side of the Sacramento Valley}

(By Tatsuro MATsumoto and W. P. Popenoe)

Upper Cretaceous beds are known in the stream valleys north, northeast and east of Redding, Shasta County, forming several discontinuous outcrops. Their geologic structure is gentle and the fossils are well preserved. The whole 
area is conventionally called the Redding area, which represents the northeastern side of the Sacramento Valley.

The area has been precisely investigated by W. P. POPENOE since 1936, who published concisely the stratigraphy in 1943. In this article POPENOE is responsible for the localities and stratigraphic positions of ammonites and inocerami, while Matsumoto is responsible for the specific identification of them. In addition to the collections of POPENOE and his associates, there is a fine set of collections recently made by M. V. KIRK and his colleagues of the Shell Oil Company. For the locality data of their ammonites, we depend exclusively on Mr. KIRK's information, although he refers his localities to PoPENOE's stratigraphic subdivisions. Two maps (Text-figs. 1 and 2) show the fossil localities, including KIRK's. Almost all the localities are indicated by pin points on air photographs, which POPENOE and KIRK keep as the original records. Some of the CAS. and LSJU. localities can be approximately compared with the localities of POPENOE and KIRK (and their coworkers), which, in turn, have respectively CIT. or UCLA. and SOC. numbers. POPENOE showed MATsumoto his sections in the field and we have obtained some more specimens on that occasion. Their localities may have TM. or LSJU. numbers, in addition to CIT. or UCLA.

The subdivisions of POPENOE (1943) are called Members I to VI. There is no comprehensive name for the whole unit for which KIRK (a letter to T. M., May 1958) suggests the name Redding formation. KIRK's suggestion seems to us reasonable, because the Cretaceous beds now exposed separately in several valleys of this general area were originally continuous before the covering by the Pliocene Tehama formation, and because they are as a whole different in facies from the Cretaceous of other areas. Although PopenoE's subdivisions, Members I-VI, are useful for the description of the stratigraphic position of the ammonites, it is probably true that the boundary of rock units goes oblique to the boundary of time-stratigraphic units. There are a few doubtful points about which we are not necessarily of the same opinion. As the doubts come from the situation of the isolated outcrops, we will describe the facts by areas. (a) The outcropping Cretaceous area along the stream valleys of Little Cow Creek and its northern tributaries.-This area (Text-fig. 1) covers the type outcrops of Members I, II, and III of PoPENOE.

Member $I$, primarily consisting of sandstones; discontinuous conglomerate at the base, resting with angular unconformity on Triassic and Paleozoic metasediments and igneous rocks; thickness about 230 meters. The localities CIT. 1208, CIT. 1195, CIT. 1444, and CIT. 1436 are included in this member, from which are identified the following species of ammonites and inocerami:

Tragodesmoceras ashlandicum (ANDERSON)

Inoceramus hobetsensis NAGAO and MATSUMOTO

Locality CIT. 1010 is referred by POPENOE to the top of Member I or base of Member II, where came:

Otoscaphites puerculus (JIMBO) [=Scaphites inermis ANDERSON]

Member II, 240 meters of silty or sandy shales with interbedded sandstones 


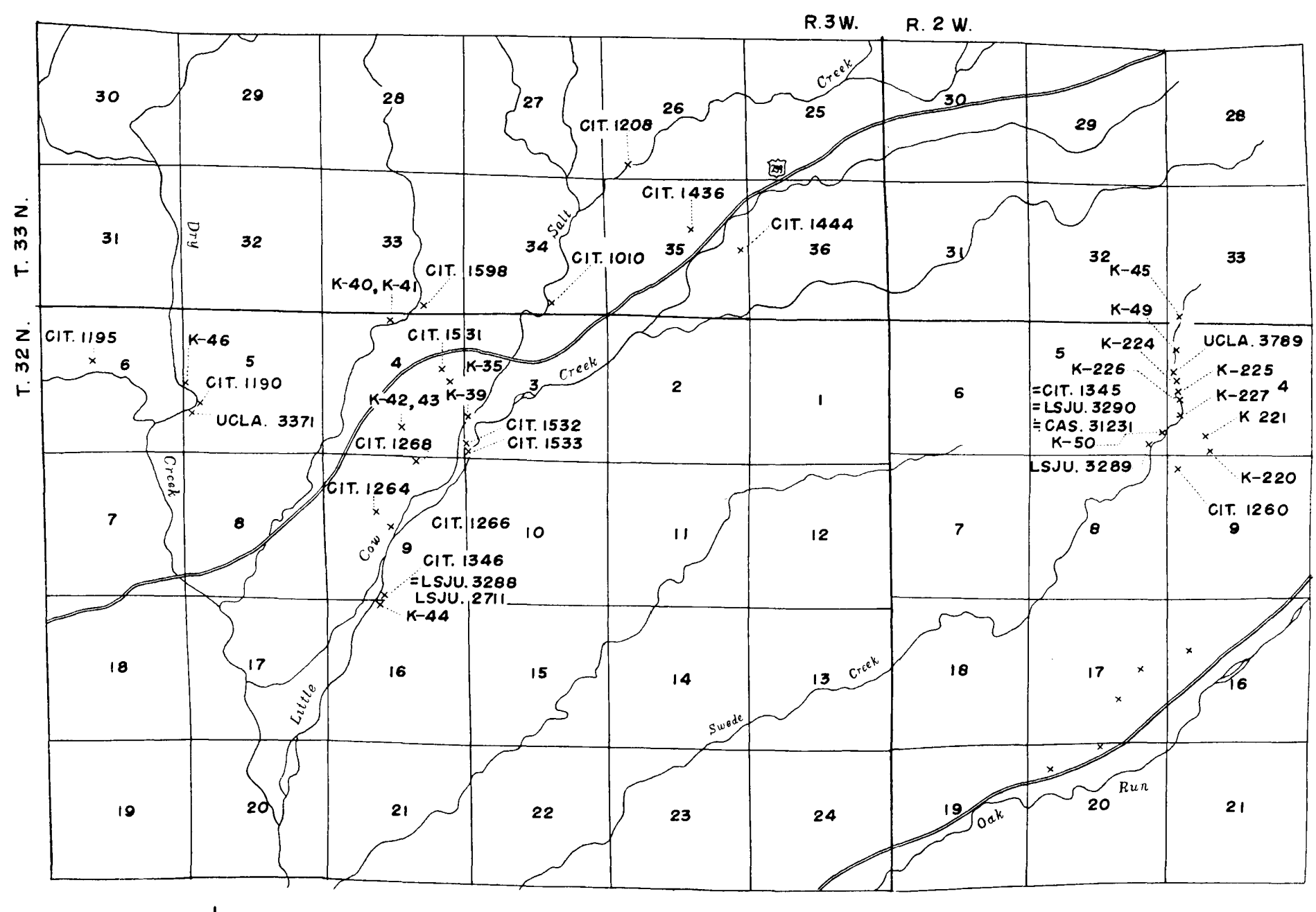

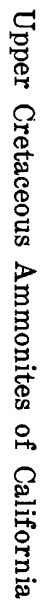

Fig. 1. Map of the Cretaceous area northeast of Redding, Shasta County, northeast side of the Sacramento Valley, showing ammonite localities-(1) (to be continued to Fig. 2). K-numbers are registered at SOC. Compiled by T. MATsumoto and W. P. Popenoe from the data of M. V. Kirk, W. P. Popenoe, and T. MATSumoto. 
and concretionary layers. To this member are referred localities CIT. 1190, SOC. K-46, CIT. 1032, UCLA. 3377 (along Dry Creek) ; CIT. 1598, SOC. K-41, SOC. K-40, CIT. 1531, LSJU. 3291 [=TM. 2005], SOC. K-42, SOC. K-35, CAS. 1293A, CAS. 31230, SOC. K-43, and SOC. K-39. From these localities the following species of ammonites have been identified:

Neophylloceras cf. ramosum (MEEK)

Mesopuzosia pacifica MATsumoto

Romaniceras deverioide (DE GROSSOUVRE) [="Mantelliceras conquistador" ANDERSON, whose type locality is CAS. 31230]

Romaniceras sp. aff. $R$. uchauxiense COLLIGNON

Eucalycoceras (?) shastense (REAGAN)

Subprionocyclus sp.

Tetragonites glabrus (JIмBo)

Bostrychoceras occidentale ANDERSON

Hyphantoceras sp.

Scaphites pittensis ANDERSON

Otoscaphites sp.

Among the above, the third species is fairly common and can be regarded as characteristic of this member.

As isolated outcrop, 1 mile north of Redding on U. S. highway 99, is the type locality (CAS.) of

Tragodesmoceras averilli (ANDERSON)

but its stratigraphic position cannot be precisely assigned. Presumably it is Member II.

Localities CIT. 1532 and CIT. 1533 belong near the top of Member II, where the following species are identified:

Jimboiceras [Kossmaticeras ?] sp.

Tetragonites glabrus (JIMBo)

Scalarites cf. mihoensis WRIGHT and MATSUmoto

Scaphites condoni ANDERSON

Otoscaphites puerculus (JIMBO)

Inoceramus cf. tenuistriatus NAGAO and MATSUMoTo

Member III, sandstones predominant over shales; about $60 \mathrm{~m}$. thick on Little Cow Creek, where the upper limit is hidden by a covering of Cenozoic sediments. All the beds from Member I to III are conformable. PopenoE gives the stratigraphic position of the locality CIT. 1268 as nearly at the base of this Member, where Otoscaphites sp. is identified.

The localities CIT. 1264 and CIT. 1266 represent the relatively lower part of Member III, whence came

Subprionocyclus neptuni (GEINITZ)

associated with

Inoceramus cf. teshioensis NAGAo and MATSUMoto

which is close to or possibly identical with $I$. costellatus Woons.

The prolific layers in the upper part of Member III in this area are repre- 
sented by the localities CIT. 1346, SOC. K-44, SOC. K-232, LSJU. 2711 and LSJU. 3288 [=TM. 2001]. I have identified the following species of ammonites from this part:

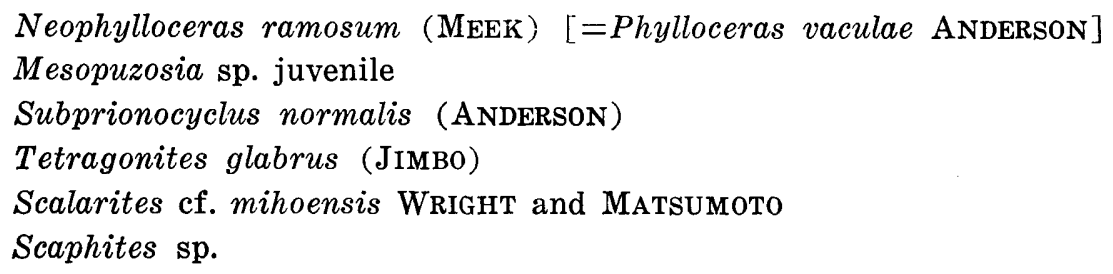

Among them the third species is very abundant and diagnostic. Other molluscan shells are also common, and a few specimens of Inoceramus ef. teshioensis NAGAo and MATsumoto have been found.

Judging from the above listed species Member I-III in this area are evidently to be referred as a whole to the Turonian. The sequence described above may represent the succession of species within the Turonian in California. There is, however, no definite evidence for the Lower Turonian in this area, while the beds characterized by Subprionocyclus normalis (ANDERSON) seem to indicate nearly the uppermost Turonian, because they are situated at the highest part of the visible succession, being higher than the beds containing Subprionocyclus neptuni (GEINITZ), a world-wide index of Upper Turonian, and because $S$. normalis is transitional to Reesidites minimus (HAYASAKA and FUKADA), an index of the top level of the Upper Gyliakian [ $\div$ Turonian] of Japan. Romaniceras deverioide (DE GROSSOUVRE) probably indicates Middle Turonian of Member II as in the type area of France.

(b) The narrow exposure of the Cretaceous along the stream valley of Swede Creek.-In the Millville Quadrangle (15 minute-series) this area is indicated as Swede Basin in the upper stream valley of French Creek, but in the Redding Quadrangle of the scale of 1:125000 the name of Swede Creek is indicated. Geologists commonly use the latter term. The Cretaceous beds of this area are considerably fossiliferous, but are unfortunately isolated from the broader outcrops of the areas described under the heading of (a) and (c). They are very gently inclined southwards (downstream), with slight undulation, and their exposure is not completely continuous. Therefore the measured section, if established, may be approximate.

The succession of the ammonoid species in the Swede Creek beds is classified into three units:

(i) The lower unit, consisting predominantly of sandstones, is exposed on the uppermost stream valley of the Swede Creek. It includes the localities, CAS. 33695 , SOC. K-45, SOC. K-49, SOC. K-223, and UCLA. 3789, from which I have identified the following ammonites:

Sciponoceras sp.

Hyphantoceras sp.

Scaphites sp.

Otoscaphites cf. puerculus (JIмво) 
(ii) The middle unit, consisting of fine sandy siltstones with interbedded sandstones, occupies the main part of the exposure in the Swede Creek. To this unit are referred the localities SOC. K-224, SOC. K-225, SOC. K-226, CIT. 1345, LSJU. 3290 [=TM. 2003], CAS. 31231, SOC. K-227, SOC. K-50, LSJU. 3289 [=TM. 2002], and SOC. K-221. The following species of ammonites have been identified :

Mesopuzosia pacifica MATsumoto

Romaniceras deverioide (DE GROSSOUVRE) [=R. hesperium ANDERSON, whose type locality is CAS. 31231]

Romaniceras sp. aff. $R$. pseudodeverianum (JIMBO)

Eućalycoceras (?) shastense (REAGAN)

Subprionocyclus neptuni (GEINITZ)

Coilopoceras (?) sp.

Hyphantoceras sp.

Among the above Romaniceras deverioide (DE GROSSOUVRE) and Subprionocyclus neptuni (GEINITZ) are diagnostic of this unit.

(iii) The upper unit, consisting primarily of concretionary shale; a sandstone may be assigned at the base of this unit. It includes the megafossil localities of SOC. K-220, CIT. 1260 [=UCLA. 3294], and CAS. 33700. The following two species of Baculites, occurring at different localities, are represented by a large number of specimens.

Baculites schencki MATSUMOTO

Baculites capensis WooDs

From the molluscan fauna other than ammonoids, as well as from lithology, POPENOE (1943) once referred the first unit to the uppermost part of Member III and the rest of the Swede Creek beds to the lower part of Member IV. MATSUMото has strong doubts about this conclusion. So far as the assemblage of ammonoid species is concerned, the upper unit only is undoubtedly comparable with Member IV of the type Oak Run area, while the middle and lower units of $60 \mathrm{~m}$. with Members III to II of the type Little Cow Creek area. Here, in Swede Creek, the assemblage of the species which characterizes the upper part of Member III in the type Little Cow Creek area is missing. Since the ammonites of the upper unit are entirely different from those of the subjacent part, a hiatus can be presumed at the base of that unit. This can explain the absence of prolific beds of Subprionocyclus normalis (ANDERSON) in this creek.

The actual exposure at the local outcrop shows that the beds are apparently parallel and conformable. But MATSUMoTo does not think this fact to be a great objection against the proposed interpretation of a hiatus. As in many other examples, this kind of relatively small stratigraphic gap is not necessarily represented by a significant structural disconformity. Although the vertical change of lithology looks gradual, it cannot be overlooked that the siltstones of the second unit show a somewhat greenish tint, as in those of Member II and III, while the shale of Member IV proper frequently shows brownish weathering surface. This may be merely due to environmental factors, but suggests a general 


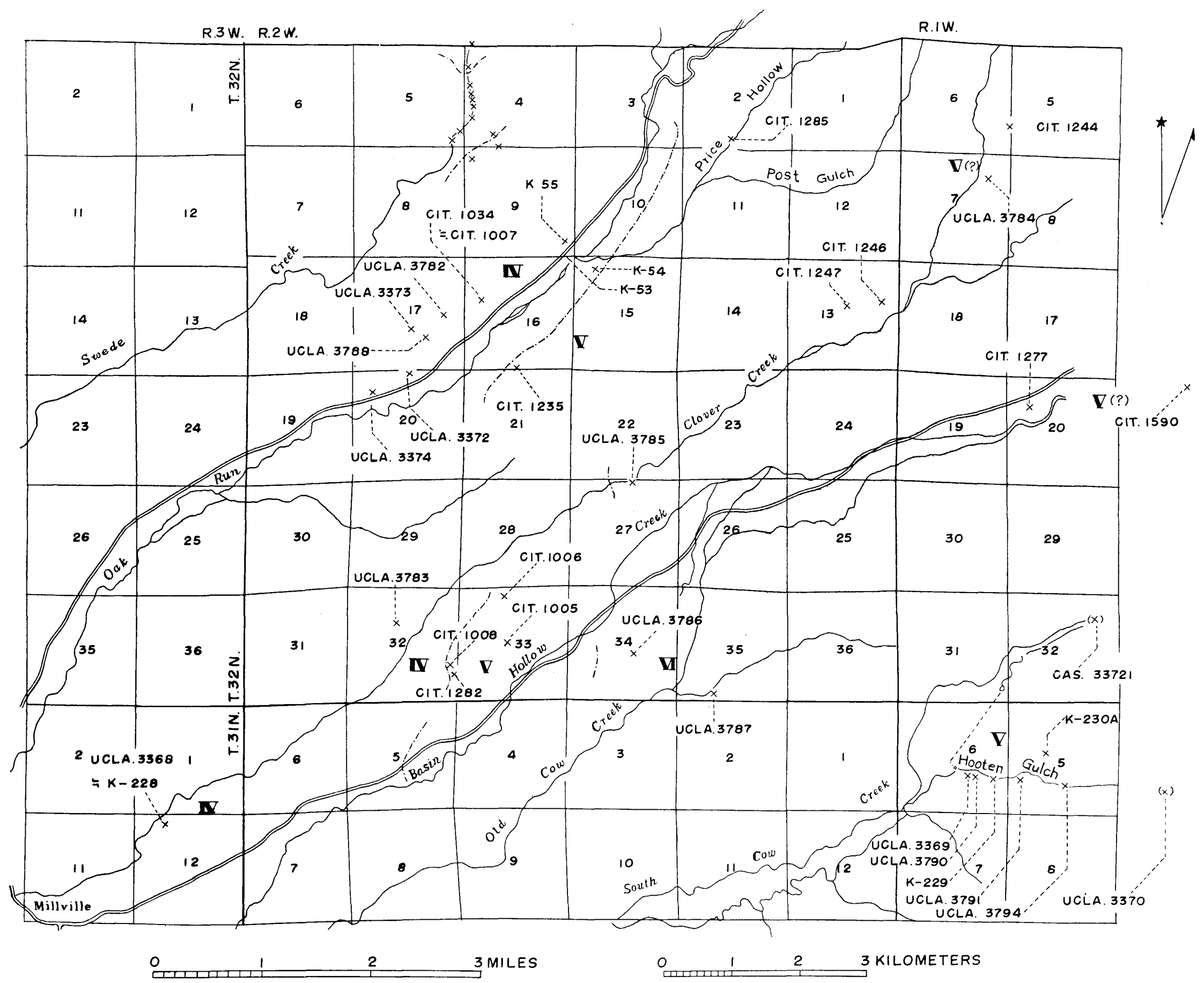

Fig. 2. Map of the Cretaceous area northeast of Redding, Shasta County, northeast side of the Sacramento Valley, showing ammonite localities -(2) (continued from Fig. 1). Compiled by W. P. Popenoe and T. Matsumoto from the data of M. V. Kirk and W. P. Popenoe. 
difference between apparently conformable series of strata. Although the covering of Pliocene volcanic ejecta prevents us from a clean cut solution of the doubtful points, the general situation in faunal features suggests us a possibility that a disconformity may exist between the subgroups of Members I-III and Member IV.

(c) The outcropping Cretaceous area along the valley of Oak Run.-This area (see Text-fig. 2) includes the type outcrop of Popenow's Member IV. The principal part of this member is a series of dark shale, interbedded with some sandstones. The calcareous concretions are contained, showing frequently brownish color when weathered. As POPENOE (1943, p. 309) has explained at length, the lower limit of Member IV is not exposed in this area, and we do not know how many meters of what kind of rocks exist between the principal part of Member IV and the upper unit of Swede Creek Cretaceous beds, the latter of which we have just mentioned. The upper limit of Member IV is probably a disconformity, overlain by the conglomerate at the base of Member $\mathrm{V}$, which, in turn, consists predominantly of sandstones. The exposed, main part of Member IV in Oak Run Valley is estimated at about 210 meters thick (see POPENOE, 1943, columnar section of fig. 2). The following mega-fossil localities are scattered throughout the whole thickness: CIT. 1007, UCLA. 3374, UCLA. 3373, UCLA. 3372, CAS. 33696, CAS. 33699, CIT. 1034, SOC. K-55, SOC. K-53, UCLA. 3782, UCLA. 3788, and K-54 at the top. A list of identified species of ammonites and inocerami follows:

Damesites damesi intermedius Matsumoto

Hauericeras sp. indet.

Eupachydiscus sp. aff. E. teshioensis (Јімво) [close to Lewesiceras beantalyense CoLLignoN]

Prionocycloceras (?) sp.

Peroniceras shastense ANDERsoN

Texanites cf. kawasakii (KAWADA)

Hyphantoceras sp.

Baculites cf. yokoyamai ToKUNAGA and SHIMIZU

Baculites schencki MATsumoto

Baculites boulei COLLIGNON

Baculites capensis WooDs

Inoceramus cf. cordiformis SOWERBY

Inoceramus n. sp. (?) aff. I. naumanni YокоҮАмА

The mega-fossil localities of Member $V$ (lower part) in this area are only CIT. 1235 and CIT. 1285, where were obtained:

Baculites cf. boulei CoLligNoN

Inoceramus cordiformis SOWERBY

(d) The Cretaceous outcrops along the valleys of Clover, Basin Hollow, and Old Cow Creeks.--Member V, which is exposed on the ridge of the southeast side of Oak Run valley, extends southwards to this area (see Text-fig. 2). The conglomerate and thick sandstone at the base can be traced. There is a slight 
structural disconformity between Members IV and $V$, but the time-gap is not great, because the faunal change is not great.

A fraction of Member IV in Clover Creek area includes localities UCLA. 3368, SOC. K-228, and UCLA. 3783, where occur:

Damesites damesi intermedius MAтsuмото

Damesites cf. sugata (ForBEs)

Eupachydiscus sp. aff. E. teshioensis (JIMBO)

Member $V$ itself primarily consists of sandstones, with some conglomerates in the lower part, at least 270 meters thick, but it changes in thickness from place to place. Molluscan shells are common in this member, but ammonite localities are few. The locs. CIT. 1006, CIT. 1008, CIT. 1282, and CIT. 1005 represent relatively lower part, containing abundant Baculites and some inocerami. The identified species are:

Baculites boulei ColligNoN

Baculites kirki Matsumoto

Baculites cf. schencki Matsumoto

Inoceramus sp. aff. I. ezoensis YoKоYAMA or I. expansus BAILY

Inoceramus naumanni YoKOYAMA

Inoceramus cf. cordiformis SOWERBY

Among them the first species occurs most abundantly.

According to the recent investigation of POPENOE, beds of Member $\mathrm{V}$ reappear on the eastern flank of a gentle syncline. The megafossil localities of this part are represented by CIT. 1590, CIT. 1277, and probably UCLA. 3784. The identified species are:

Baculites cf. boulei ColuignoN

Baculites capensis Woods

Inoceramus cf. cordiformis SOWERBY

Also CIT. 1246 and CIT. 1247 may be referable to Member V, whence came:

- Baculites cf. schencki Matsumoto

Allocrioceras (?) sp. indet.

Member VI consists of dark shales with interbedded sandstones, about 150 meters thick. There are conglomerates near the junction of Members $V$ and VI. The two members are apparently conformable. The localities UCLA. 3785, UCLA. 3786, and UCLA. 3787 are included in Member VI, from all of which came characteristically:

Inoceramus orientalis ambiguus NAGAO and MATSUMoTo

(e) The outcropping Cretaceous area along the stream valley of South Cow Creek.-Another good display of Member VI and upper part of Member V is in this area (see Text-fig. 2). The ammonite localities are rather concentrated in the highest part of Member V. They are UCLA. 3370, UCLA. 3794, UCLA. 3791, SOC. K-229, SOC. K-230A, UCLA. 3790, and UCLA. 3369. The following species of ammonites and inocerami have been identified from these localities:

Pseudoschloenbachia sp. aff. P. boulei (BASSE)

Texasia (?) [new genus ?] sp. 
Bostrychoceras sp. aff. B. otsukai (YABE)

Hyphantoceras venustum (YABE)

Baculites cf. bailyi Woons

Baculites kirki MATSUMOTO

Inoceramus naumanni YoKoYAMA

Inoceramus cf. cordiformis SOWERBY

The first species, associated with the sixth, is characteristic of this part.

The localities CAS. 33721 and CAS. 33727 are probably referable to Member $\mathrm{V}$, containing:

Baculites sp. indet.

Pseudoschloenbachia sp.

Inoceramus cf. ezoensis YoKоYAMA

Inoceramus cf. cordiformis SOWERBY

POPENOE has recently clarified that at one place sandstone with a good Member V faunule includes Pseudoschloenbachia, Damesites, and Inoceramus cf. cordiformis SOWERBY; a very short distance above are silts with Inoceramus orientalis ambiguus NAGAO and MATSUMOTO in the basal beds of a thick section of Member VI.

Generally speaking, the species of Baculites are common throughout the sequence in Members IV and V. Although any one member contains more than one species, different species of Baculites are rarely intermixed at one locality. The stratigraphical ranges of Baculites species may be fairly long, showing overlapping among different species, but the diagnostic species, which are more common in one unit than in others, are:

Baculites schencki MATsUmoto

Baculites boulei CoLLIGNON

in Member IV

Baculites kirki MATSUMOTO

in the lower part of Member $\mathrm{V}$

in Member $\mathrm{V}$ (both the lower and upper parts)

The diagnostic species of Baculites in Member VI has not yet been recognized.

In other groups there are a few world-wide species and also some which are identical with or closely allied to the Japanese species. But in many species of the Indo-Pacific region the geological range is long, and may show different local range among different provinces.

Peroniceras and Prionocycloceras are usually regarded as Coniacian indices, but the former can range up to Lower Santonian.

The occurrence of Eupachydiscus sp. aff. E. teshioensis (JIMBo) with other species of Member IV is rather unusual from the standpoint of the Japanese succession, but it is not quite identical with the typical example from the Japanese Santonian, resembling as it does Eupachydiscus isculensis (REDTENBACHER) of the Alpine Upper Coniacian and also "Lewesiceras" beantalyense CoLLIGNoN of the Malgash Coniacian. A find of Texanites cf. kawasakii (KAWADA) in Member IV is another apparently unfavorable fact, but Texanites appears already in late Coniacian in certain places of the world. 
Pseudoschloenbachia sp. aff. P. boulei (BASSE) indicates that the highest part of Member $\mathrm{V}$ is not older than Upper Santonian. P. boulei (BASsE) itself is regarded as an index of the Lower Campanian in Madagascar (BEsAIRIE and Collignon, 1956), but the Californian example is not quite identical with typical Malgash ones. The associated species suggest rather Upper Santonian than Lower Campanian, so far as the upper part of Member $\mathrm{V}$ is concerned.

Aside from ammonites, inocerami are good indicators of age. I. cordiformis SOWERBY is fairly common in the lower part of Member V and I. sp. cf. cordiformis also occurs in Members IV and upper V. In England this species is known in the zones of Micraster cortestudinarium, M. coranguinum, and Uintacrinus westfalicus, i.e. Coniacian to middle part of Santonian. What has been called Inoceramus mukawaensis NAGAo and MATSUMOTO is closely allied to, or possibly identical with, I. cordiformis SOWERBY. It occurs in the zone of I. mihoensis and superjacent part, probable Upper Coniacian and Lower Santonian, of Japan. While Inoceramus naumanni YoKoYAMA has a relatively long range, being rather abundant in the Santonian of Japan, Inoceramus orientalis ambiguus NAGAO and MATSUmoto, a transitional subspecies between typical 1 . naumanni and Lower Campanian I. orientalis SokoLOW, is common in the upper part of the Santonian (i.e. upper Neourakawan) of Japan.

From all of these and other available reasons, Member IV and the lower part of Member $\mathrm{V}$ are referred to the Lower Senonian, probably the Upper Coniacian and Lower Santonian respectively, and the highest part of Member $\mathrm{V}$ and also the lower part of Member VI to the Upper Santonian. There is, however, no positive evidence (such as Barroisiceras) for the Lower Coniacian. The possibility still remains that the upper part of Member VI is Lower Campanian.

Summarizing the above, the Cretaceous of the Redding area is important for the study of ammonites (and probably also other associated groups) of the Turonian, Coniacian, and Santonian of California. The discontinuous outcrop is indeed an obstacle, but further careful field work will furnish more and better material, clearing up ambiguous points.

\section{Chico Creek and other scattered outcrops on the east side of the Sacramento Valley}

There are several, isolated, narrow outcrops of the Upper Cretaceous on the east side of the Sacramento Valley, from which ammonites have been obtained. The best known is Chico Creek, Butte County. A few narrow exposures also occur in adjacent Little Chico and Butte Creeks, and near Pentz, about 10 miles north-northwest of Oroville, or about 15 miles east-southeast from the center of the city of Chico. Much further north of them another small outcrop exists in the upper stream valley of Mill Creek, near the southwest flank of Lassen volcano, Tehama County. Still further north there is an old established, but little known, locality in Battle Creek, near the boundary of Tehama and Shasta Counties. To the south near Sacramento another old and poorly investigated locality is recorded at Folsom, in Placer County. 
Quite recently a new locality for Upper Cretaceous ammonites has been found by the geologists of the University of California in the "Miocene area" near Milton, Calaveras County. A small outcrop at the foot of Sutter Buttes, Sutter County, has also furnished some ammonites. These two areas are treated here, for convenience' sake, although they are not on the east side of the Sacramento Valley in a true sense.

(a) Chico Creek, Butte County.-This is the type locality of the Chico formation. The locality data of older collections, such as TRASK (1856), GABB (1864, 1869), and ANDERSON (1902), are not precise enough to indicate the stratigraphic positions of the described species. TAFF, HANNA, and Cross (1940) first showed a columnar section and a geological sketch map, in which several localities (CAS.) are distributed within a 2175-foot thickness of sediments. They described only two, Trask's species of ammonites from one locality, CAS. 27838. Subsequently PoPENOE (1943, p. 312) very briefly mentioned preliminary results of his study of molluscan faunas that are differentiated, though gradationally, into three parts in the section of Chico Creek. Recently PECK, IMLAY, and PoPENOE (1956) and also POPENOE (1957) have given their preliminary conclusions on correlation of the Chico formation, without, however, showing a complete list of ammonoid species. An important proposal of PECK et al. (1956, p. 1982) is that the usage of Chico as a stratigraphical term "should be abandoned as a group or series name, but that it might usefully be retained as a formational name for the rocks at and near the type locality on Chico Creek."

The Chico formation at Chico Creek itself rests with a marked unconformity on older metamorphic rocks. The basal part, at least 90 meters thick, is conglomeratic; cobble-boulder conglomerate at the very base grading upward into pebbly, occasionally cross-laminated, coarse sandstone, still with intercalated conglomerate layers. The principal part of the formation consists of bluish, greenish, grey, more or less silty, medium to fine-grained sandstones. Calcareous concretions are common, often forming layers in the lower part, but occurring rather sporadically in the upper part. The sandstones are massive on the exposure, but occasionally thin silty beds and pebbly layers may be found. Fossils are rare in the basal conglomerate but common throughout the whole of the rest of the formation. They are in a good state of preservation in the calcareous concretions and also in the county rock of the sandstone itself. Pelecypods, gastropods, and scaphopods predominate over ammonites, but the latter can be collected from various levels by careful work.

Owing to the covering of the Tascan volcanic formation, the Cretaceous rocks are exposed only on the walls and bluffs of the creek and the gullies. The beds incline gently to the west-southwest. The Cretaceous exposures along Chico Creek are fairly continuous although sometimes interrupted by the covering of recent river gravels and vegetation. Due to the narrow outcrops, examples of certain species once obtained at a locality in a fine state of preservation may not be collected again during the next trip to the same locality. Frequent visits by many persons, however, have resulted in the accumulation of a considerable 
number of ammonoid specimens.

In addition to the collections of TAFF et al., which are preserved at the California Academy of Sciences, I have studied those of R. E. Cook in Stanford, and also others in the University of California (Berkeley) and the Shell Oil Company. Stewart CHUBer and I spent three days in Chico Creek, collecting ammonites at various levels of the section. We have plotted our localities on a columnar section through airphotographs. Still more specimens have been supplied me for study by Dr. PoPEnoe and Mrs. Lou Ella Saul of UCLA., with locality data of reliable accuracy. Mrs. SAUL has, furthermore, prepared a columnar section putting the localities of UCLA. and CIT., and tied them up with the localities of CHUBER and MATsumoto (with TM. or LSJU. numbers). By kind permission of the persons concerned, a combined columnar section and an index map of ammonite localities (Text-figs. 3 and 4) are presented here. Some of the localities of TAFF et al. and COOK can be approximately allocated on the same charts. I hope Mrs. SAUL will publish further details of the stratigraphy and paleontology in the type Chico area.

A doubtful point at this moment is the correct estimation of the thickness in the type section of the Chico formation. TAFF et al. estimated the total thickness at 2175 feet $[\doteqdot 660 \mathrm{~m}$.], which was followed by Cook (MS. PH. D. Thesis at Stanford). The estimation of CHUBER and I is not much different from that, being only slightly larger. SAUL, however, gave me much thicker measurements. This is not the place to discuss the question further, but the relative succession of ammonites is important. There is no significant controversy about the latter point among us.

From the standpoint of ammonites, the Chico formation in Chico Creek can be divided in two: a lower half and an upper half. With our present knowledge, the lower part can be subdivided further in two, although the basal unit has so far yielded insufficient ammonites.

I. Basal Unit, which approximately corresponds to the lithological basal conglomeratic member. Several mega-fossil localities are included in this unit, among which a species of Baculites have been obtained from loc. CIT. 1014, UCLA. 3617, and LSJU. 3310 [=TM. 1001]. That baculites is:

Baculites schencki MATSUMOTO (a variety with relatively smoothish surface and subtrigonally ovoid cross section)

II. Upper part of the lower half of the section, which includes in its lower part the localities UCLA. 3619, CIT. 1016, and UCLA. 3623, containing:

Hauericeras sp.

Mesopuzosia cf. densicostata Matsumoto

Hyphantoceras venustum (YABE)

Bostrychoceras sp. (multicostate form)

Scalarites [or Polyptychoceras ?] sp.

Baculites sp. juvenile (of yokoyamai group)

and in its upper part the localities LSJU. 2880, LSJU. 3307 [=TM. 1004], LSJU. 1806d [ $\doteqdot$ CAS. 28173], LSJU. 3304 [=TM. 1007], CAS. 27835, LSJU. 3303 
[=TM. 1008], LSJU. 3302 [=TM. 1009], UCLA. 3627, UCLA. 3633, SOC. K-178, and CIT. 1017. The last locality was once considered to be fairly low in the section, but SAUL carefully inspected the record, with the result that it may not

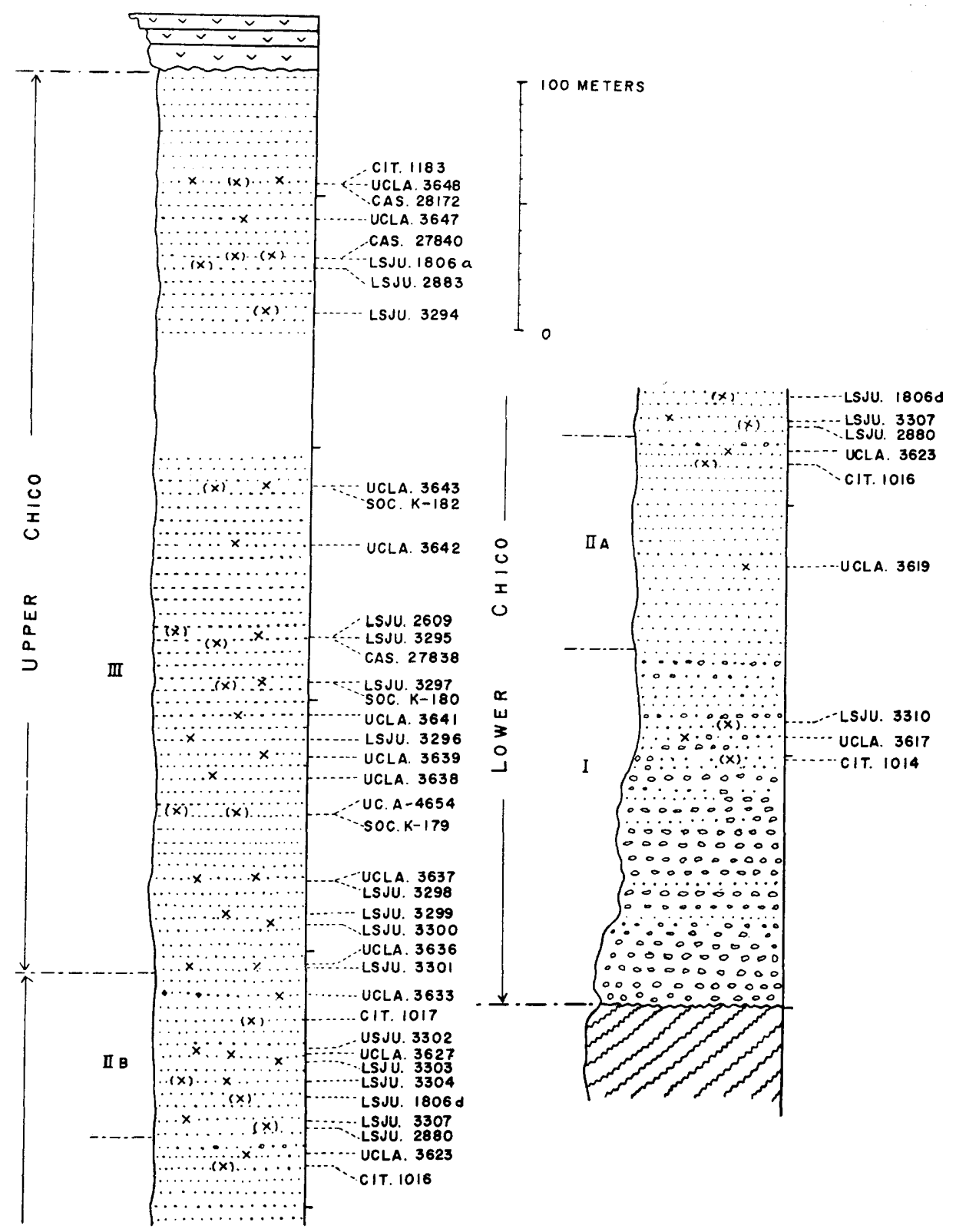

Fig. 3. Columnar section of the Chico formation along the type Chico Creek, showing the stratigraphic positions of ammonite localities. $(x)$ : approximate allocation. Compiled by T. MATsumoto from the data provided by W. P. Popenoe, L. E. Saul, Stewart Chuber, and T. Matsumoto. 


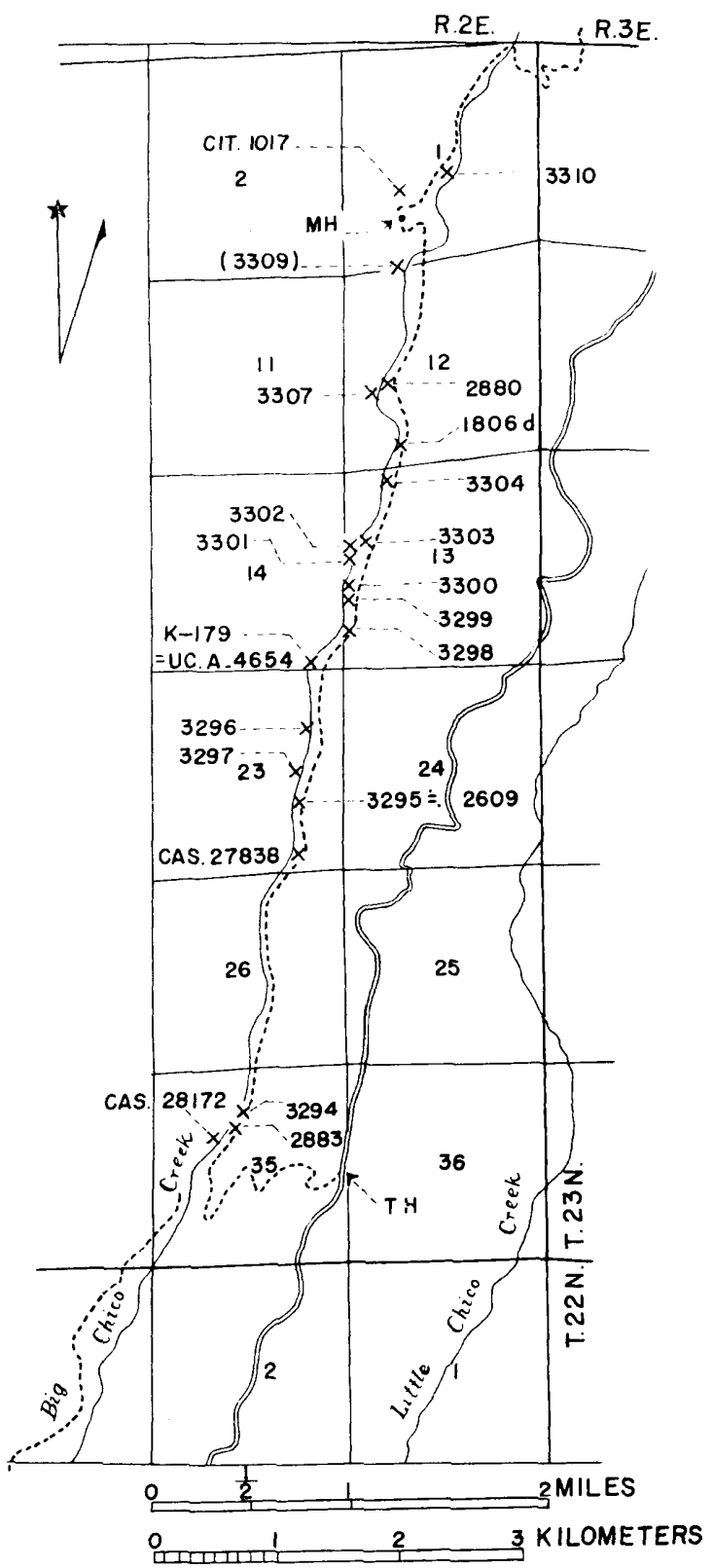

Fig. 4. Map of the Chico Creek area, Butte County, northeast side of the Sacramento Valley, showing ammonite localities. All the numbers belong to LSJU., unless otherwise stated. No ammonite has been found from loc. LSJU. 3309. MH: Mickey's house, TH: Site of Ten-mile house. Compiled by T. Matsumoto from the data of W. P. Popenoe, L. E. SAUL, Stewart Chuber, TafF, Hanna, \& Cross, R. E. Cook, and T. Matsumoto. 
be lower than loc. UCLA. 3627 (personal communication, March 20, 1958). The following species of ammonites have been identified from these localities:

Hauericeras (Gardeniceras) angustum YABE [=Hauericeras mickeyi ANDERSON, whose type locality is CAS. 27835]

Gaudryceras sp. cf. denmanense WHITEAVES

Hyphantoceras venustum (YABE) [=Bostrychoceras buttense ANDERSON]

Bostrychoceras sp. aff. B. otsukai (YABE)

Polyptychoceras (?) sp. cf. obstrictum (JIMBO)

Baculites capensis Woods [including B. buttensis ANDERSON, whose type locality is at CAS. 27835]

Among the above, the last species is most abundant and diagnostic. Also the following species of inocerami are associated with them:

Inoceramus naumanni YoKOYAMA

Inoceramus sp. cf. undulatoplicatus RöMER [or I. japonicus NAGAO and MATSUMOTo]

Inoceramus sp. cf. I. ezoensis YoKoYAMA

III. Upper half of the section, which has furnished more ammonites than the lower half. It includes, approximately in ascending order, the localities LSJU. 3301 [=TM. 1010], UCLA. 3636, LSJU. 3300 [=TM. 1013], UCLA. 3637 [ $\doteqdot$ LSJU. 3298], SOC. K-179 [=UC. A-4654], UCLA. 3638, UCLA. 3639, LSJU. 3296 [TM: 1016], SOC. K-181, UCLA. 3641, SOC. K-180, LSJU. 3297 [=TM. 1014], LSJU. 3295 [=TM. 1015], LSJU. 2609, CAS. 27838, UCLA. 3642, UCLA. 3643, SOC. K-182, LSJU. 3294 [=TM. 1017], UC. A-4655, LSJU. 1806a [=CAS. 27840], LSJU. 2883, UCLA. 3647, UCLA. 3648, and CIT. 1183 [=CAS. $28172 \div$ UCLA. 3648]. I have identified the following species of ammonites from these localities:

Neophylloceras cf. ramosum (MEEK)

Pachydiscus buckhami UsHeR

Pachydiscus cf. neevesi Whiteaves

Canadoceras yokoyamai (JIMBO)

Canadoceras newberryanum (MEEK)

Canadoceras mysticum MATsumoto

Canadoceras sp. nov. (?)

Submortoniceras chicoense (TRASK)

Submortoniceras studleyi (ANDERSON)

Gaudryceras cf. denmanense WHITEAVES

Zelandites sp. aff. Z. kaiparaensis MARSHALL

Glyptoxoceras (?) sp.

Ryugasella ryugasensis WRIGHT and MATSUMOTO

Pseudoxybeloceras (?) lineatum (GABB) [includ. Oxybeloceras taffi ANDERSON]

Baculites chicoensis TRASK

Among the above Submortoniceras chicoense (TRASK) and Baculites chicoensis TrASK are most abundant and diagnostic of this unit. Throughout the entire 
thickness (slightly over 300 meters even in the minimum estimation) of the unit there is no significant change in the elements of the assemblage. Baculites chicoensis TRASK occurs throughout, and Submortoniceras chicoense (TRASK) is known from loc. UCLA. 3637 [ $\doteqdot$ LSJU. 3298=TM. 1013] up to loc. UCLA. 3647. But, among the four listed species of Canadoceras, C. yokoyamai (JIMBo) is rather common in the lower part, and C. newberryanum (MEEK) is, as far as known, restricted to the upper one third of the unit; the other two Canadoceras species occur sparsely in the lower part. In the old collections there are a fine example of C. yokoyamai (JIMBo) at loc. UC. 2699 and two of C. newberryanum (MEEK) at loc. USGS. 398. The locality data are not precise enough to trace them back into my subdivisions. Pachydiscus buckhami UsHeR and P. neevesi WHITEAVES seem to be fairly long-ranged as are Gaudryceras denmanense Whiteaves, Ryugasella ryugasensis WRIGHT and MAtsumoto, and Pseudoxybeloceras lineatum (GABB). As regards inocerami it should be noted that Inoceramus japonicus NAGAO and MATSUMOTO (perhaps =I. undulatoplicatus RömER) does not occur in the upper half, that $I$. sp. aff. $I$. ezoensis YokoYAMA (related to $I$. expansus BAILY), represented by a large form, was found in the middle part of the upper half, and finally that I. subundatus MEEK was obtained from loc. CIT. 1183, the highest mega-fossil locality along the Chico Creek. In this connection, it may be recalled that Metaplacenticeras was recorded as having occurred in the higher part of the section in Chico Creek. This information is very doubtful, because no example of this species has been confirmed in recent collections from the Chico area. The only evidence which I have found is a specimen, MCZ. 2074, in the old collection at the Museum of Comparative Zoölogy at Harvard College, which labelled "Placenticeras californicum ANDERson, Chico Creek." This is again doubtful, because it differs in mode of preservation from the usual specimens of Chico Creek.

The assemblage of species of Unit III in Chico Creek is entirely different from that of any subdivisions of the Cretaceous rocks in the Redding area, while that of Units I and II has common elements with that of Members IV, V, and VI of the Redding area. Because many of the common species are relatively long-ranged, correlation between Chico Creek and the Redding area on a fine scale is rather difficult. But it can be safely concluded that the basal part of the Chico formation in the type Chico area is not older than Member IV of the Redding formation. If we could find somewhere in the Chico section Peroniceras shastense ANDERSON and Pseudoschloenbachia sp. aff. P. boulei (BASSE), which characterize respectively Member IV and Member V (top) of the Redding section, the correlation between the two areas would become finer. The listed species of Unit II in the Chico formation are mostly common with the species of the Japanese Santonian [=Upper Urakawan]. Therefore, Unit II is most probably to be assigned to the Santonian, and Unit I may possibly go down to the Coniacian.

Unit III, i.e. the upper half of the Chico formation, is characterized by the abundant occurrence of Baculites chicoensis TRASK and Submortoniceras 
chicoense (TRASK) and also an association of Canadoceras species. From knowledge of the world distribution of Submortoniceras and Canadoceras, Unit III is best referred to the Campanian. Baculites chicoensis TRASK has not been confirmed outside California, and even within California it does not occur as commonly as was once incorrectly thought, except in the Chico area. But the species comes above the beds of the Lower Senonian group of Baculites, i.e. B. schenki Matsumoto, B. yokoyamai TokunAGA and ShImizU, and B. capensis Woods. It does not, so far as is known, intermingle with the other group of Baculites, i.e. B. inornatus MEEK, B. occidentalis MEEK, and B. sp. aff. B. anceps LAMARCK, which is associated with other ammonites and inocerami of Upper Campanian aspect.

Unit III is, therefore, most reasonably referred to the lower half of the Campanian. If the Campanian is subdivided into three parts, the Middle as well as the Lower Campanian may be represented in the upper half of the Chico formation. This possibility is postulated from the facts that Canadoceras newberryanum (MEEK) and Inoceramus subundatus MEEK are known in the higher part and that Submortoniceras chicoense (TRASK) (showing a great variation) is generally allied to the species of the Middle Campanian in Madagascar.

Summarizing the above, the Cretaceous beds of Chico Creek are proved from the evidence of ammonites and inocerami to range from somewhere in the Lower Senonian to about the middle of the Campanian. Thus the formation represents only a fraction of the Upper Cretaceous. Aside from the historical complexity, this fact can support the proposal of PECK et al. (1956) that the term Chico is better used as a local formational name rather than a group or series name.

(b) Little Chico and Butte Creeks, Butte County.-The Cretaceous outcrops along these creeks are close to that of Chico Creek, which is often called Big Chico. Owing to the interruption of exposures by the covering of Tertiary volcanic rocks, the tracing of a bed from one creek to another is difficult. The localities of ammonites at my disposal are CIT. 1040, SOC. K-199, LSJU. 2882, UC. 2701, UCLA. 3793, SOC. K-185, and CAS. 27837. I have identified the following species from them:

\section{Pachydiscus buckhami USHER \\ Canadoceras yokoyamai (JIMBo) \\ Submortoniceras chicoense (TRASK) \\ Baculites chicoensis TRASK \\ Inoceramus cf. ezoensis YoKоYАMA}

From this assemblage, as well as from lithology and geographical position, the fossiliferous rocks on Little Chico and Butte Creeks are regarded as an extension of the upper half of the Chico formation on Chico Creek. Locality UCLA. 3793, from which Canadoceras newberryanum (MEEK) was found by SAUL, can be assigned to the relatively higher part of the section in Butte Creek. Locality from which a well preserved example of Canadoceras yokoyamai (JIMBO) was collected, is not precisely recorded. 
(c) Pentz, between Chico and Oroville, Butte County.-This area has been well known since the time of GABB (1864). It is often called Pentz or Pences ranch. In this area a limited thickness of very fossiliferous layers crop out in the beds of small gullies and on the banks of Dry Creek. The predominant rocks are silty sandstones with some interbedded siltstones. Fossils are accumulated in certain calcareous lenses. They are mostly pelecypods and gastropods. Only a few species of ammonites have been identified from localities LSJU. 3293 [=TM. 1000], SOC. K-186, UC. A-963, UC. A-6588, CAS. 1125, and CIT. 1012.

Canadoceras cf. newberryanum (MEEK)

Submortoniceras chicoense (TRAsK)

Submortoniceras studleyi (ANDERSON)

Bostrychoceras cf. declive (GABB)

Baculites chicoensis TrAsK

From this assemblage the fossiliferous layers of the Pentz area are probably to be correlated with the uppermost part of the Chico formation in Chico Creek.

(d) A locality in Mill Creek, Tehama County.-Ammonites, along with some other mollusks, have recently been collected by Professor S. W. MULLER from a locality, LSJU. 3355, on Mill Creek, 300 meters north of "Pape Place". According to him the fossiliferous mudstone crops out there beneath the Cenozoic volcanics. The area is so narrow that no stratigraphic sequence is observable. By his courtesy I have studied the ammonites and identified the following species:

Canadoceras yokoyamai (JIMBo)

Canadoceras n. sp. (?) aff. C. hoepeni CollignoN

Hauericeras (Gardeniceras) cf. angustum $\mathrm{Y}_{\mathrm{ABE}}$

Tetragonites sp.

Glyptoxoceras sp.

Among the associated mollusks diagnostic is:

Inoceramus naumanni YoKoYAMA

The assemblage suggests that the mudstone can be regarded as transitional between Units II and III of the type Chico formation, although the lithology is dissimilar. The age may be lowest Campanian, but might be highest Santonian. More specimens, especially of short-ranged species, are needed for a finer correlation.

(e) Battle Creek, Tehama County.-This is a poorly known locality with one ammonite species:

\section{Peroniceras tehamense (GABB)}

The only information about the locality is GABB's (1864, p. 61) description that the specimens were "presented to the Geological Survey of California by a gentleman at Battle Creek, Tehama County and said to have come from the vicinity."

On studying GABB's original specimens, preserved in the University of California, Berkeley (UC. 12102, 14850, and 14851), I have recognized that the species is indistinguishable from Peroniceras rousseauxi DE GRossouvRe (1894, 
p. 102, pl. 11, fig. 5) from the middle part of the Coniacian in France. Therefore the fossiliferous rock of the Battle Creek area could include the Coniacian part in terms of the international scale. Because of the importance of this locality for world correlation and because of its geographical position between the Redding and Chico areas, the stratigraphy and paleontology of the Battle Creek Cretaceous area should be investigated in more detail.

(f) Near Folsom, Placer County.-This is another area where little information is available. It is represented by localities CAS. 23553, CAS. 33709, and UC. A-6589. They are also called "Rock Corral", "Texas Flat", "Trach's ranch", and sometimes simply Folsom (Folson); but they are situated outside Sacramento County, in Placer County. There is no reliable record of the stratigraphic succession. The species which I have identified are:

Baculites inornatus MEEK

Baculites cf. occidentalis MEEK

Inoceramus cf. subundatus MEEK

From straight comparison with the faunas of the Vancouver and adjacent islands, the fossiliferous beds near Folsom are to be correlated with part of the Nanaimo group, probably within the Campanian. It should be noted, however, that there is no common species of Baculites between this faunule and Chico formation in the type area. This may be due to difference in age and not in facies. The fossiliferous beds near Folsom probably belong to the Upper Campanian. Unfortunately we have no record of Baculites chicoensis occurring in a bed directly subjacent to the beds with $B$. inornatus and $B$. occidentalis.

Incidentally Folsom is the type locality of Inoceramus whitneyi GABB, 1869, which resembles Inoceramus subundatus MEEK, 1862 and also Inoceramus balticus Böнм, 1907.

(g) Sutter Buttes, Sutter County.-Sutter Buttes, sometimes called Marysville Buttes, are isolated rugged hills which rise abruptly 600 meters above the center of the Sacramento Valley. The main course of the Sacramento River now runs just west of the hills. The buttes consist primarily of younger Cenozoic volcanic rocks, surrounded by Miocene non-marine beds. Beneath them a portion of the Upper Cretaceous series crops out in a narrow area. There are two CAS. ammonite localities (CAS. 365 and another without number) in this area. The identified species are

Pachydiscus sp. juvenile cf. P. egertoni (ForBES)

Baculites cf. inornatus MEEK

The country rocks are silty and calcareous, occurring with calcareous sandstone. According to H. R. JoHNSON (in KIRBY, 1943, p. 301) the fossiliferous rock is in the upper part of a measured 2650 2750-foot [810 840-meter] Cretaceous section, immediately below their contact with the overlying Eocene Capay beds.

The above listed ammonites are of course insufficient for precise age determination, although they may suggest a relatively higher part of the Upper Cretaceous, probably Upper Campanian.

(h) Near Milton, Calveras County.-This is a new discovery by a geologist 
in the University of California, who will, I hope, report the geology of the locality. I just want to mention here that the specimens are referable to

Metaplacenticeras cf. pacificum (SмIтH)

which suggests the Upper Campanian. I have been informed that the fossils were obtained from an area where Miocene was indicated on a published geological map. This locality, so far as is known, indicates the southern limit of the distribution of the Upper Cretaceous on the east side of the Great Valley.

\section{Ono area, northwest side of the Sacramento Valley}

The area which is mostly included in the Ono Quadrangle (15 minute topographic sheet) is very important for Californian Cretaceous stratigraphy. This area is here concisely called the Ono area, although Ono itself is a small village.

The area is famous for the Lower Cretaceous ammonites rather than for the Upper. A considerable number of GABB's (1864, 1869) type-specimens came from "Cottonwood Creek", which runs through this and adjacent areas. F. M. ANDERSON (1938) described a great number of ammonoid and other species from the Lower Cretaceous of this area, which he attempted to subdivide into zones of particular nomenclature. His geological map was, however, broad and sketchy, his geological profiles were schematic, and no index map of fossillocalities was presented. On the same outline map and profiles the Upper Cretaceous was also indicated. The ammonoid and other groups of fossils higher than the Upper Albian in this area have recently been described by ANDERsoN (1958).

MURPHY (1956) published the result of his precise stratigraphic work in the northern part of the same area, establishing ammonite zones for the Lower Cretaceous. At Professor POPENOE's suggestion, Peter U. RoDDA is now working on the Upper Cretaceous of the same area. Although he kindly showed me their collections as well as locality data, I do not intend to cite them here, awaiting the completion of his work. But a few important species may be mentioned.

The material for my study of ammonites of the Ono area came from diverse sources, including the collections of SOC. and CAS. The locality data of the former have been kindly supplied me by Mr. M. V. KIRK, by whose permission I show here an index map (Text-fig. 5) of the localities. Since the strata incline homoclinally towards southeast, we can judge the stratigraphic order of the occurrence of ammonites. The localities of CAS. are often too broadly recorded to be plotted on the same map but some of them can be approximately allocated in comparison with the localities of KIRK (and also of RODDA). The data may be sorted in the following way.

(a) Succession of ammonites in the section along the North Fork of Cottonwood Creek and its tributaries, Huling [=Hulen] Creek, etc., Shasta County.-For the Lower Cretaceous MURPHY (1956, fig. 5) gave a map of reliable accuracy. The first unit in the description below is judged to be included in MURPHY's zone of Pervinquieria hulenana. Other units evidently come above it.

(i) The unit represented by locality CAS. 1346, which is one of the important 


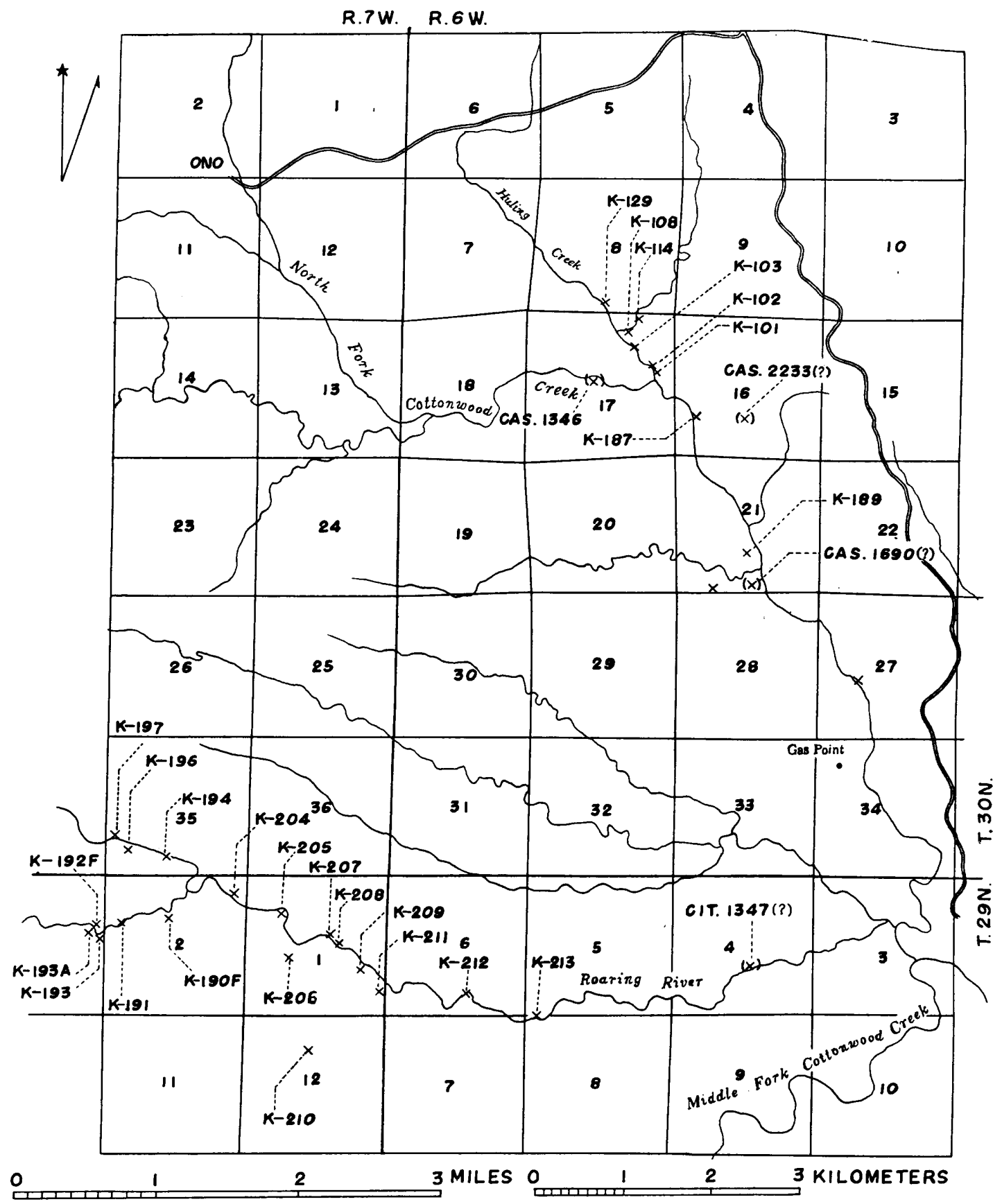

Fig. 5. Map of the Ono area, Shasta County, northwest side of the Sacramento Valley, showing ammonite localities. K-numbers are registered at SOC. Compiled by T. MATSUмото from the data provided by M. V. KIRK. Some of CAS. Iocalities and two of P. U. RODDA's (without numbers) are also indicated. $(x)$ : approximate allocation. 
sources of ammonites for ANDERSON (1958). I show here a revised list of species.

Desmoceras (Pseudouhligella) dawsoni Whiteaves [including Beudanticeras alamoense ANDERSON, 1958 and Beudanticeras argonauticum ANDERSON, 1958, holotypes]

Pachydesmoceras colusaense (ANDERson) [=Puzosia (Parapuzosia) colusaensis ANDERSON]

Mortoniceras kiliani (LASswITZ) [=Pervinquieria sylvana ANDERSON, 1958, holotype and Pervinquieria gainesana ANDERson, 1958, holotype]

Anagaudryceras cf. sacya (FoRBES)

The locality is said to be in a conglomerate of silty matrix. Close to CAS. 1346, there is another locality, CAS. 5944, whence came, as ANDERson (1958) reported, Beudanticeras [Brewericeras ?] haydeni (GABB)*

The locality CAS. 1346A, which is recorded as if it was slightly west of CAS. 1346 , is the type locality of

Desmoceras (Pseudouhligella) barryae ANDERSON

This species is closely allied to, but is distinguishable from, Desmoceras (Pseudouhligella) ezoanum MATSUмото, and is possibly a direct derivative from $D$. (P.) dawsoni WhItEAves. The relative stratigraphic position of the two Californian species, $D$. ( $P$.) .dawsoni and $D$. ( $P$.) barryae ANDERSON is now being carefully examined by MURPHY and RODDA. Among the specimens which I have studied, other than ANDERSON's holotype, there are a few probable examples of this species from loc. SOC. K-187, which is situated in the unit to be described under iv.

(ii) The next unit comes just above the level where MurPhy (1956, text-fig. 5) indicated the upper limit of the zone of Pervinquieria hulenana. This is recorded as another fossiliferous layer containing conglomerates. It is represented by the localities SOC. K-102, SOC. K-101, and SOC. K-188**, in ascending order, and probably LSJU. 3278. The identified species are:

Beudanticeras [Brewericeras ?] haydeni (GABB)

Desmoceras (Pseudouhligella) cf. dawsoni WHITEAVES

Pachydesmoceras colusaense (ANDERSON)

Mortoniceras (Deiradoceras) sp.

Stomohamites sp.

Lechites aff. gaudini (PICTET and CAMPICHE)

Another specimen to be mentioned here is the holotype of Stoliczkaia praecursor ANDERSON (1958, p. 246, pl. 12, fig. 1, 1a) [=Stoliczkaia dispar of ANDERSON, 1902, p. 63, 106] from loc. UC. 3823, "Cottonwood district." But whether this locality should be referred to unit ii, iii, or otherwise is not clear. ANDERson (1958, p. 246) mentioned that it is associated with Mortoniceras tehamense (REAGAN).

* CASEY (1954) regarded this species as an example of his Brewericeras, but I have some doubts about his assignement.

** No ammonites have been found from loc. SOC. K-188. 
(iii) There is a considerable thickness of strata between the units ii and iv, but I have no material of ammonites from this part, except for small specimens in the collection of UCLA., which could be regarded as immature Graysonites sp., and can be allocated to this level, as RoDDA told me.

(iv) The uppermost part of the conglomeratic member comes here. It includes localities SOC. K-187, with SOC. K-187 F, and probably also CAS. 2233. The ammonites from them are:

Neophylloceras seresitense (PERVINQUIÈRE)

Desmoceras (Pseudouhligella) barryae (ANDERsoN)

D. (P.) hindsi (ANDERSON) [A deformed specimen, not exactly criticized]

Eogunnarites n. sp.

Calycoceras cf. newboldi (Kossmat)

(v) The lowest part of the more shaly sequence above the conglomerate of iv. The valley abruptly widens here. Locality CAS. 3440 represents this unit, characterized by:

Sciponoceras baculoide (MANTELL)

I have recognized Desmoceras (Pseudouhligella) japonicum YABE as well as Sciponoceras baculoide (MANTELL) in RODDA's recent collection from the corresponding unit.

(vi) Somewhat higher than the preceding unit, but still in the shaly sequence, are referred SOC. K-189*, and probably CAS. 1690A. The latter is important, because it contains

\section{Plesiovascoceras cf. californicum ANDERSON}

but the locality record is not accurate enough to be indicated as a point on the map.

(vii) The next unit is presumably represented by locality CAS. 1690, showing fossiliferous greenish grey silty shale. The relative stratigraphic position of CAS. 1690 in relation to CAS. $1690 \mathrm{~A}$ should be reexamined in the field. The contained ammonoid species are:

Mesopuzosia sp.

Romaniceras cf. deverioide (DE GROSSOUVRE)

Collignoniceras sp. juvenile cf. woollgari (MANTELL)

Gaudryceras cf. denseplicatum (Jімво)

Tetragonites glabrus (Jімво)

The last species is represented by a relatively well preserved specimen, but others are poorly preserved.

(viii) The highest visible part in the section of the North Fork of the Cottonwood Creek comes under this heading. PoPENOE (1957, text-fig. 1) indicates the occurrence of Subprionocyclus at this top level. RoDDA showed me specimens from a locality about a half mile north of Gas Point (607 on the topographic

* According to KIRK (a letter, Oct. 21, 1958), the material from SOC. K-189 seems to have been lost, but as he recalls, contained poorly preserved ammonites. 
sheet). They are poorly preserved, but referable to Subprionocyclus sp.

I have been informed that the sandstones are more predominant in this unit than in the subjacent parts (v-vii).

(b) Succession of ammonites in the section along the Roaring River, Shasta County, a tributary to the Cottonwood Creek.-M. V. KIRK has provided me with very useful locality data along the Roaring River. They are indeed a good addition to MURPHY's data for the Lower Cretaceous (MURPHY, 1956, text-figs. 3 and 4), but I do not intend to plot KIRK's data directly on MURPHY's map. I am responsible for the identification of the species listed below.

(i)-(ii) The upper part of the "Ono formation" of MURPHY (1956) in his geological map. Localities SOC. K-197, SOC. K-196, SOC. K-195, and SOC. $\mathrm{K}-194$, in ascending order, may be included in this part, although KIRK (personal communication Oct. 1958) doubts whether the term "Ono formation" would be strictly applicable to his localities from K-197 to K-204. The ammonoid species are:

Desmoceras (Pseudouhligella) cf. dawsoni WHITEAVES

Beudanticeras [Brewericeras ?] cf. haydeni (GABB)

Stomohamites sp.

(iii) This unit includes localities SOC. K-193A, SOC. K-193, SOC. K-191, SOC. K-190F, and probably SOC. K-204. It may correspond to the uppermost part of the "Ono formation" of MURPHY's rock unit, just below the predominantly conglomeratic part. The following two ammonites are characteristic of this unit.

Desmoceras cf. kossmati Matsumoto

Graysonites wooldridgei Young

(iv) The conglomeratic member crossed by the Roaring River is not so fossiliferous as that of the North Fork of Cottonwood Creek. KIRK (personal communication, October 1958) has shown me evidence to conclude that the conglomerate horizons on Cottonwood Creek and on Roaring River are not necessarily of the same unit.

(v) Fairly high above that prominent conglomerate mentioned above, there are two ammonite localities, SOC. K-205 and then SOC. K-206. They have a particular assemblage of species, different from that below.

Desmoceras (Pseudouhligella) cf. japonicum YABE

Marshallites n. sp. [an involute and finely ribbed one, the same as an undescribed new species from the Upper Cenomanian of Japan]

Anagaudryceras sp.

Zelandites cf. inflatus MATSUMOTo

Sciponoceras baculoide (MANTELL)

(vi) There are fossil localities SOC. K-207 and SOC. K-208, but the specimens of ammonites are not at my disposal. They may or may not belong to the preceding unit. Somewhat above them there are localities SOC. K-209, SOC. K-210, and SOC. K-211, from which KIRK obtained several interesting ammonites: 
Puzosia intermedia orientalis Matsumoto

Mesopuzosia sp. indet.

Kanabiceras septemseriatum (CRAGIN)

Mammites (?) sp.

Plesiovascoceras californicum (ANDERsON)

(vii)-(viii) The fossil localities are much scattered along the lower course of the Roarding River. Sandstones are frequently intercalated in the shale. The localities SOC. K-212 and SOC. K-213 certainly represent much higher part than SOC. K-211. The identified species are:

Mesopuzosia sp.

Pachydesmoceras cf. pachydiscoide Matsumoto

Subprionocyclus sp.

(ix) Still further to the east, not far from the mouth of the Roaring River, POPENOE discovered another ammonite locality, CIT. 1347, whence came:

Damesites damesi intermedius MATSUMото [=Kotoceras frazierense ANDERSON]

Gaudryceras denseplicatum (JIмB0)

The latter was misidentified by ANDERSON (1958, p. 183, pl. 40, fig. 1) as Gaudryceras tenuiliratum YABE.

(c) Middle Fork of Cottonwood Creek, boundary of Shasta and Tehama Counties.-There are a few ammonite localities along the river valley, but their positions in stratigraphic sequence are not precisely recorded. At locs. CAS. 33730 and CAS. 34408, of a greenish, dark grey shale, came:

Collignoniceras sp. juvenile cf. woollgari (MANTELL)

(d) Dry Creek, Tehama County.-This creek seems to be important for establishing the succession of ammonites, linking it with those along other forks of Cottonwood Creek. ANDERSON (1958, p. 23-24) has recently showed a succession along it. But the ammonites at my disposal did not cover the whole of his material, leaving some doubtful points, although I can add here some of KIRK's collection. The available data can be rearranged in ascending order as follows (Text-fig. 6).

(i) The part including the locality CAS. 28180, that is the type locality of "Pervinquieria furberi ANDERSON" (1958, p. 258, pl. 11, fig. 1, holotype). This is closely allied to Mortoniceras kiliani (LASSwITZ).

(ii)-(iii) A conglomerate containing some shells. As has been informed by KIRK (personal communication), it is still uncertain whether this is or is not an extension of the conglomerate on Roaring River. No ammonite has been found there. ANDERSON (1958) indicated an unconformity at its base, but I have no opinion about the relationship. Anyhow the criteria for the uppermost Albian and the lowest Cenomanian are needed.

(iv) The part represented by the loc. CAS. 31097, that was recorded by ANDERSON at "about 300 feet above the local base of the Upper Cretaceous". He listed at this locality "Desmoceras (Latidorsella) inane (STOLICZKA), Turrilites aff. T. bergeri (BRONGNIART), and Cyrtochilus stylus ANDERSON". They are 


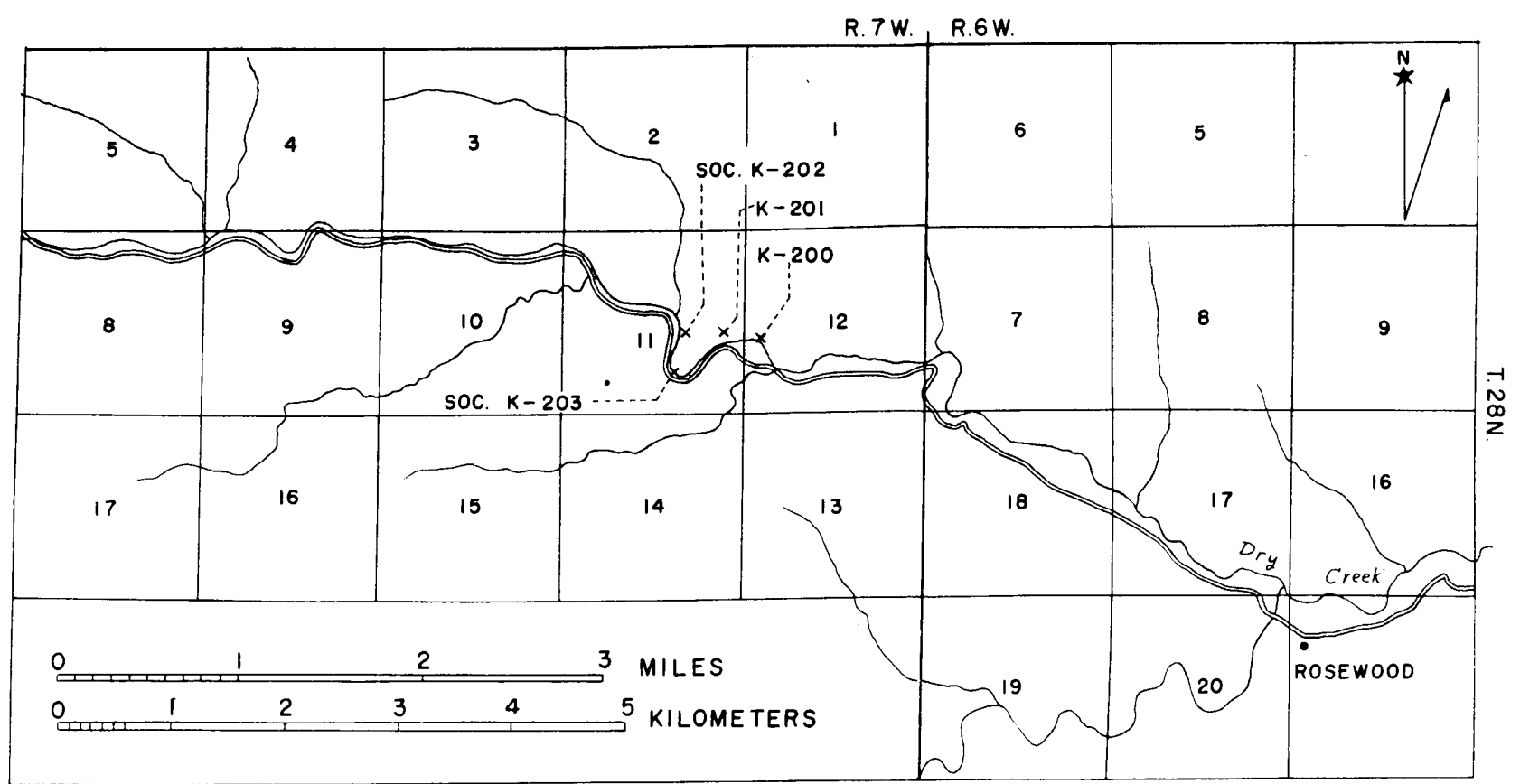

Fig. 6. Map of Dry Creek area, Tehama County, northwest side of the Sacramento Valley, showing ammonite localities. The data are provided by M. V. KIRK. Blank space is left for a reader to plot CAS. localities of F. M. ANDERSON (1958, p. 23, fig. 1), which I cannot at present indicate precisely on this map. 
in my identification:

Desmoceras (Pseudouhligella) poronaicum (YABE)

Mariella sp. aff. M. miliaris (PICTET and CAMPICHE)

Sciponoceras kossmati (NowAK)

This assemblage is doubtful, because Sciponoceras kossmati very probably indicates Lower Turonian but others Cenomanian or older age.

(v)-(vi) Although ANDERSON listed Baculites aff. B. chicoensis at loc. CAS. 28178, and several species of acanthoceratids at locs. CAS. 31098 and CAS. 31099, fairly high above CAS. 31097, the specimens were not at my disposal.

(vii) Evidently east of, according stratigraphically above, the preceding locality comes a unit of alternating sandstones and shales. This part contains localities SOC. K-202, SOC. K-203, SOC. K-201, and probably also SOC. K-200, being characterized by

Collignoniceras cf. woollgari (MANTELL).

The species is represented by a large number of small, probably immature, specimens, but there are a few, fragmentary, outer whorls.

(viii) Although the records are not accurate, localities CAS. 33703, CAS. 31101, CAS. 31100, and CAS. 31102 are distributed to the east of the foregoing group of localities. They have furnished the following ammonites:

Pachydesmoceras pachydiscoide MATSUMOTо [=Pachydiscus rosewoodensis ANDERSON]

Mesopuzosia cf. indopacifica (Kossmat)

? Lewesiceras sp. (poorly preserved)

Subprionocyclus sp.

Scalarites cf. scalaris (YABE)

In addition to them there is another locality, CAS. 2245, the record of which is too broad for precise allocation. This is, however, the type locality of ANDERsoN's three new species:

\section{Parapuzosia (Austiniceras) giganteum (ANDERSON) \\ Jimboiceras cf. planulatiforme (JiмBo) [=Puzosia (Eocanadoceras) hannai ANDERSON] \\ Coilopoceras hyatti ANDERSON}

The paratype of the first species (ANDERson, 1958, p. 239, pl. 16, fig. 2) is recorded by ANDERSON to have been found "in a long gulch, 1 mile north of Middle Fork of Cottonwood Creek, near horizon of Vascoceras shastense (ANDERSON)". The specimen is, however, missing, and I cannot give any comment. Neither can I give reliable information about his "horizon of $V$. shastense". (e) Horsetown and the vicinity.-Between the major outcrops of the Cretaceous of Ono and Redding, there are very narrow and discontinuous exposures of the Cretaceous strata at and near the old town called Horsetown. Since the Cretaceous rocks of the Ono and Redding areas are considerably different in stratigraphic sequence, rock-facies, thickness, and geologic structure, this intermediate area should be geologically investigated. At the suggestion of Professor Popenoe, Peter U. RoDDA is now undertaking field work, which should lead to interesting 
results.

The only Upper Cretaceous ammonite which I have recognized in the old collections is Collignoniceras woollgari (MANTELL) at CAS. 465. This was designated as a paratype of Calycoceras (Metacalycoceras) auspicium ANDERSON (1958, p. 243, pl. 20, fig. 9), which is evidently a misidentification. There is an example of Baculites chicoensis Trask with a label of loc. CAS. 465-A, Texas Springs near Horsetown. But from Texas Springs a few species of Albian ammonites are known. The lithology of this specimen of $B$. chicoensis is dissimilar to the others. Therefore the record of $B$. chicoensis TRASK from this area is extremely doubtful.

It is regrettable that the term Horsetown was applied as the group name for the upper half of the Lower Cretaceous, because Horsetown is too small a place to be the title of a major formational (or series) unit and because the exposures at Horsetown are too discontinuous to define the upper and lower limits of the group and to show the stratigraphic sequence. Be that as it may, we have to use the group name from the standpoint of priority.

(f) A summary of conclusions about the Upper Cretaceous of the Ono area.The above described data are far from a perfect scheme of the stratigraphic sequence to be established for the Upper Cretaceous of the Ono area, but they may be of use as a preliminary note. The following paragraphs give a summary of my conclusions.

From the order of succession and from the assemblage of species, the provisional units (i) to (viii) can be correlated among the three parallel sections (a), (b), and (d). These units should be examined further in the field to allow the establishment of well defined zones or subzones. The assemblage as well as the individual diagnostic species approximately indicate the following assignements.

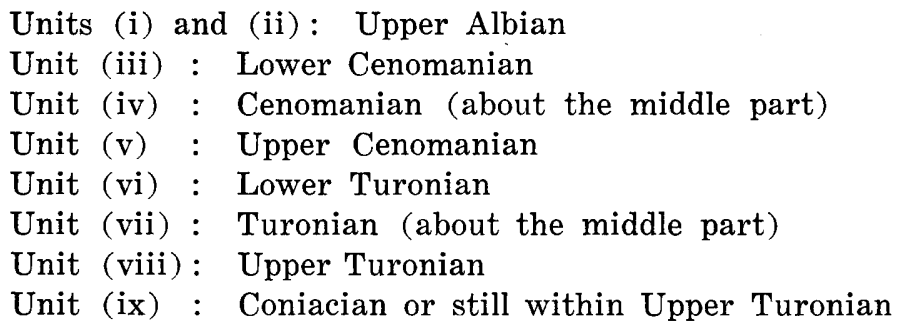

Outstanding is the common occurrence of Collignoniceras cf. woollgari (MANTELL) in unit (vii) and the corresponding part almost throughout the area, although the specimens are not always well preserved. This unit is interesting in that it contains common elements with Member II of the Redding area. It should be noted here that an example of Eucalycoceras (?) shastense (REAGAN) was obtained by KIRK from Member II of the Redding formation and that the type locality of the same species is, according to REAGAN (1923), somewhere in the Cottonwood Creek (LSJU. 121). Nobody has been successful in getting additional specimens of this species from the Cretaceous of the Ono area, but they should be searched for, because the species is important for both taxonomy and 
correlation.

Another point which should be noted is that the upper or lower limit of the conglomeratic part is not of quite the same age between the sections of Cottonwood North Fork and Roaring River. In other words the boundary of the major rock units may not coincide with the time boundary of the Upper and Lower Cretaceous series.

\section{Rumsey Hills, Sites, and adjacent areas on the west side of the Sacramento Valley}

In the Ono and adjacent areas of Shasta and Tehama Counties on the northwest side of the Sacramento Valley, only the lower part of the Upper Cretaceous, approximate equivalent to Cenomanian plus Turonian in terms of the international scale, is proved to be exposed. The rest of the Upper Cretaceous is covered by the late Teritary and Quaternary Tehama and Redd Bluff formations. From Glenn County southward, through Colusa, Yolo, Napa, to Solano County, on the west side of the Sacramento Valley, the outcrop of the Upper Cretaceous is extensive, and even the higher part occurs on the southwest side of the Valley. In this area, however, the ammonite localities, so far as I know, are rather scanty; the well preserved specimens occur only in a few limited, narrow portions. Micro-fossils, which can be obtained more commonly from the shaly rocks, have been, and are indeed, important for local correlation, but ammonites, inocerami, and certain other mega-fossils, even though scattered, give us good control for age determination.

Stratigraphic subdivision of the Upper Cretaceous on the west side of the Sacramento Valley was attempted by $\operatorname{KIRBY}(1943$, a, b). It was based on the exposures in the Rumsey Hills-Cache Creek area (northern Yolo and southern Colusa Counties) and the Sites-Logan Ridge area (northern Colusa and southern Glenn Counties). KIRBY recognized the following sequence in ascending order, proposing six formational names:

I. Top of the Lower Cretaceous Shasta Series. Dark shales comprising this part has been called the "Antelope shale", although this name is pre-occupied by earlier use.

II. Venado formation (576-1065 meters thick): Sandstones predominant, with occasional conglomeratic layers near the base and some shales in the middle.

III. Yolo formation (333-157 meters): Dark grey shales predominant, frequently alternating with thin beds of sandstones, sometimes rich in foraminifera.

IV. Sites formation (1202-38 meters): Sandstones predominant, alternating with minor sandy shales.

V. Funks formation (188-754 meters): Grey shales, with some intercalated sandstones, sometimes siliceous, containing radiolaria.

VI. Guinda formation (902-37 meters): Sandstones predominant, with intercalated shales. 
VII. Forbes formation (910 meters or less): Siltstones containing limy concretions, with subordinate sandstones.

Overlying: Late Tertiary gravels and the Eocene Capay formation (where it is not removed) rest unconformably on the Cretaceous beds.

These formational names have been used by subsequent authors. KIRBY gave an outline geological map, several route maps, and geological profiles, but he did not indicate ammonite localities on the maps, and no reliable lists of ammonites were given. Because there are local litholic changes and because the geologic structure is not simple, there is sometimes difficulty in referring a given outcrop to any of the above formations. Very few published geological maps are available for this extensive area on the fine scale required by ammonite paleontologists.

Recently geological mapping in this general area has been started by geologists of the U. S. Geological Survey, universities, and oil companies. While I was in California, Stewart CHUBER, a graduate student of Stanford University, was doing geological field work in Fruto Quadrangle, Glenn County. He kindly took me to his field area and also to adjacent areas. This was very helpful for understanding KIRBY's subdivision, as well as for getting some more specimens. I visited also a few localities in Capay Quadrangle, during a paleontological excursion held under the leadership of Professor Durham of the University of California.

The locality data of this area for the ammonites which I have dealt with were offerred by Stanford University, including the record of Mr. KIRBY and Professor S. W. MULLER, the California Academy of Sciences, the University of California, Mr. M. V. KIRK of the Shell Oil Company, and Messrs. Stewart CHUBER and C. W. CuIne. The information from diverse sources is here sorted as follows:

(a) Rumsey Hills-Cache Creek area.-The mega-fossils of KIRBY and Crook's collection are at Stanford, but there are no indications of formational names on the labels. Their geographic positions are accurately recorded, so most of them can be assigned to KIRBY's subdivision. An outline geologic map, Capay ValleyWilbur Spring, prepared for the Pacific Section of the American Association of Petroleum Geologists Spring Field trip, May 7-8, 1954 is useful for correct judgement. I have compiled an index map of ammonite localities (Fig. 7).

(i)-(iii) No ammonites are at my disposal from the lower three units of this area.

(iv) Sites formation: Localities LSJU. 1997 and LSJU. 1999 are referable to the uppermost part of the Sites formation. From them I identify the following mega-fossils :

A bituberculate pachydiscid [Pseudojacobites or Menuites]

Scaphites cf. yokoyamai Jімво

Otoscaphites cf. puerculus (JIMBo)

Inoceramus sp. (group of I. lamarcki-cordiformis)

(v) Funks formation: KIRBY indicated in the southern part of the mapped 


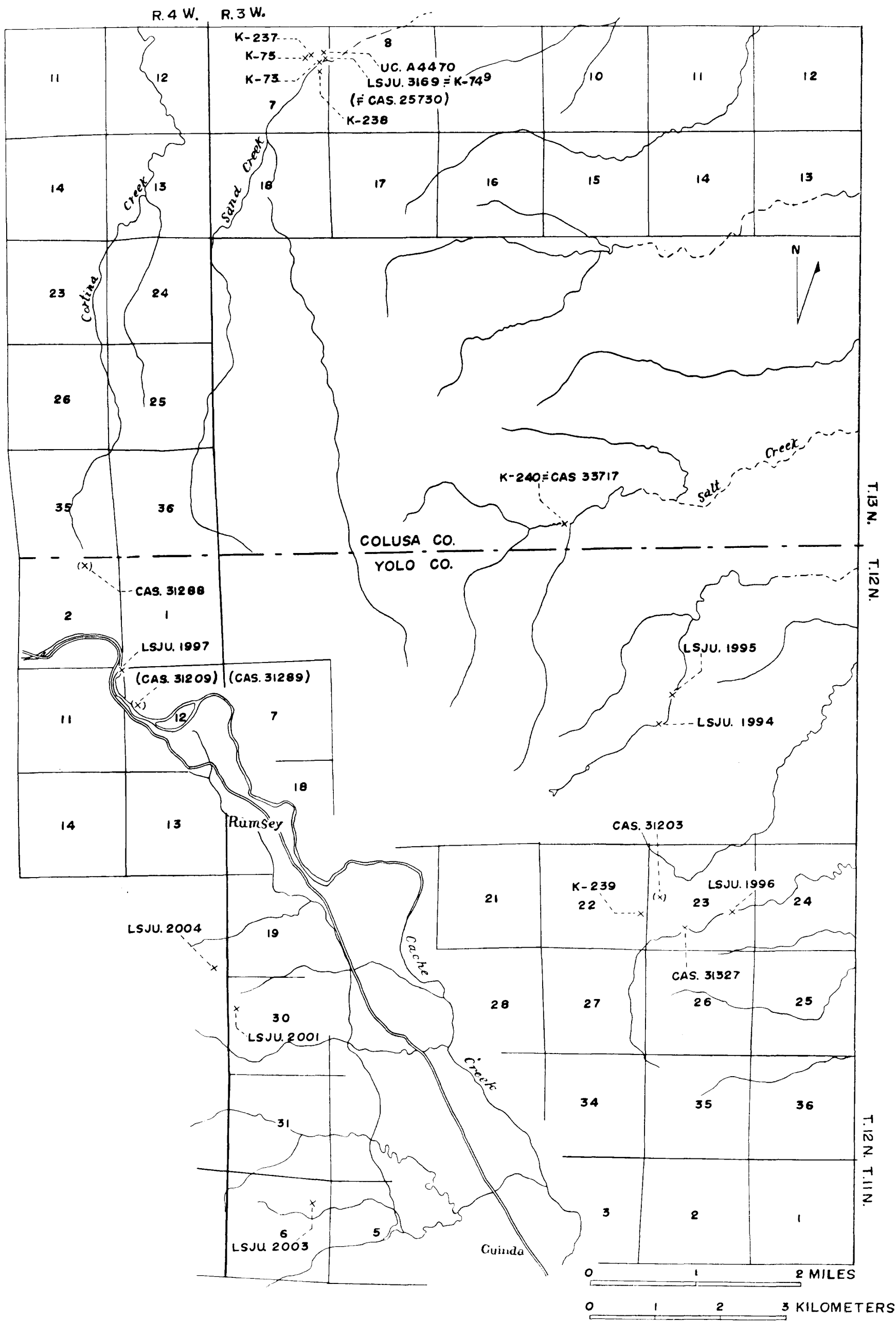

Fig. 7. Map of the Rumsey Hills-Cache Creek area, Colusa and Yolo Counties, west side of the Sacramento Valley, showing ammonite localities. Compiled by T. Matsumoto from the data provided from LSJU., CAS., UC., and SOC. K-numbers belong to SOC. (Read CAS. 31208 for CAS. 31203.) 
area Funks sandstone below Funks shale. Locality LSJU. 2006 presumably belongs to the former; it contains

Neophylloceras cf. ramosum (MEEK)

Localities LSJU. 2001, LSJU. 2003, LSJU. 2004, and probably UC. A-5179, CAS. 31115, CAS 31288, and CAS. 31289 belong to the unmistakable Funks shale. The ammonites which I have identified are as follows:

Peroniceras sp.

Prionocycloceras crenulatum (ANDERSON)

Gaudryceras cf. tenuiliratum YABE

Hyphantoceras cf. venustum (YABE)

Scalarites sp. (a densicostate species)

Baculites schencki Matsumoto

Baculites capensis WooDs

(vi) Guinda formation: No ammonites have been found, except at a doubtful locality, LSJU. 1998. This falls in the area which was indicated as a small, faulted block of the Guinda sandstone. The topography suggests the possibility that the locality is at the northern edge of a narrow ridge of Sites sandstone and shale. It contains :

Bostrychoceras sp. aff. B. indicum (STOLICZKA)

Scalarites (?) sp.

Inoceramus sp. (group of 1 . naumanni YoKочAMA)

(vii) Forbes formation: Several isolated exposures in Sand Creek, Salt Creek, Buckeye Creek, and Nigger Heaven in Rumsey Hills are referred to the Forbes formation. They are represented by the mega-fossil localities LSJU. 3169, CAS. 25730, SOC. K-73, SOC. K-74, SOC. K-75, SOC. K-237, SOC. K-238, SOC. K-240, UC. A-4470, CAS. 33717, SOC. K-239, and CAS. 31208. The fossils often occur in limy concretions, and some of the specimens are well preserved. Judging from KIRBY's description, map, and geological profile, most, if not all, of the above localities belong to the basal part of the Forbes formation which is characterized by fossiliferous limy concretions. The species which I have identified are as follows:

Canadoceras cf. newberryanum (MEEK)

Patagiosites arbucklensis (ANDERSON)

Anapachydiscus californicus (YABE)

Gaudryceras striatum (JIMBO)

Baculites cf. inornatus MEEK

Inoceramus schmidti MICHAEL

Inoceramus sachalinensis SoKoLow

The second species is most characteristic of this part, but has received from ANDERSON a number of unnecessary other new names (see descriptions in Part II). The third species is only known from loc. CAS. 31327 as a fragmentary specimen. The last two species of Inoceramus are zonal indices in the Lower Hetonaian (Middle to Upper Campanian) of Japan and Sakhalin, of British Columbia and a part of the Matanuska and Chignik formations of Alaska, where 
they have sometimes been misidentified as Inoceramus undulatoplicatus RöMER.

Unfortunately Baculites chicoensis TRASK and Submortoniceras chicoense (TrASK) have not been found in any of the units in the section of Rumsey Hills. It is, however, very probable that the Forbes formation represents the horizon immediately above the main part of the Chico formation of the type area, being referable to the transition between Middle and Upper Campanian. Therefore the Guinda formation should be searched for the two Chico species. For the Upper Campanian proper, there are localities in Enos Canyon to be described below.

The assemblage of species from the Funks shale indicates the close resemblance to that of Member IV of the Redding area, suggesting a Coniacian age. There are no good indices like Subprionocyclus, Collignoniceras, and Romaniceras in the hitherto identified species of the Sites formation, but the species from the upper part of that formation suggest the Turonian or Coniacian.

(b) Logan Ridge-Sites area, southern Glenn and northern Colusa Counties.No good fossil localities are recorded in the Wilbur Spring Quadrangle which separates the Cache Creek-Rumsey Hills area from the Logan Ridge-Sites areas. North in the Lodoga and Fruto Quadrangles (15-minute series), there is a considerable number of mega-fossil controls, which I have fortunately studied. I call the area temporarily Logan Ridge-Sites area, because the geological records are better concentrated there (Fig. 8).

Logan Ridge stretches meridionally on the west side of the Sacramento Valley, extending from Blue Ridge in the Rumsey area. KIRBY's several sections were actually taken from exposures in creeks which cut across this continuous ridge. Geologically the ridge itself is composed of Venado sandstones which incline eastward at moderate angle. Conformably above the Venado sandstone come homoclinal beds of Yolo shale, Sites sandstone, Funks shale, and Guinda sandstone formations, occupying the eastern flank of the ridge and also the lower foot hills. Very few mega-fossils have been found from these beds. At locs. LSJU. 3283 [=TM. 3015] and LSJU. 3292 [=TM. 3018], on the west flank of the ridge, from the lower part of the Venado sandstone CHUBER and I obtained :

\section{Inoceramus cf. labiatus SCHLOTHEIM}

Below this sandstone, on the west flank of the same ridge, a unit of dark colored siltstones crops out. It contains irregular conglomerates of silty matrix and also patches of sandstones. The dark siltstone has furnished a considerable number of cephalopoda, gastropoda, and pelecypoda (including rudistids). Although about a 15-meter thickness of the siltstone unit is exposed, it is not easy to distinguish minor levels within it, because the exposures are not completely continuous and because the base of the Venado sandstone may not be a reliable datum line. The localities are, however, distinguished as far as possible, although many of them are concentrated near the place called "PETERson ranch". They are LSJU. 3168, LSJU. 3276, LSJU. 3277, LSJU. 3279, LSJU. 3280, LSJU. 3282 [=TM. 3013], LSJU. 3284 [=TM. 3016], LSJU. 3286 [=TM. 3019], 


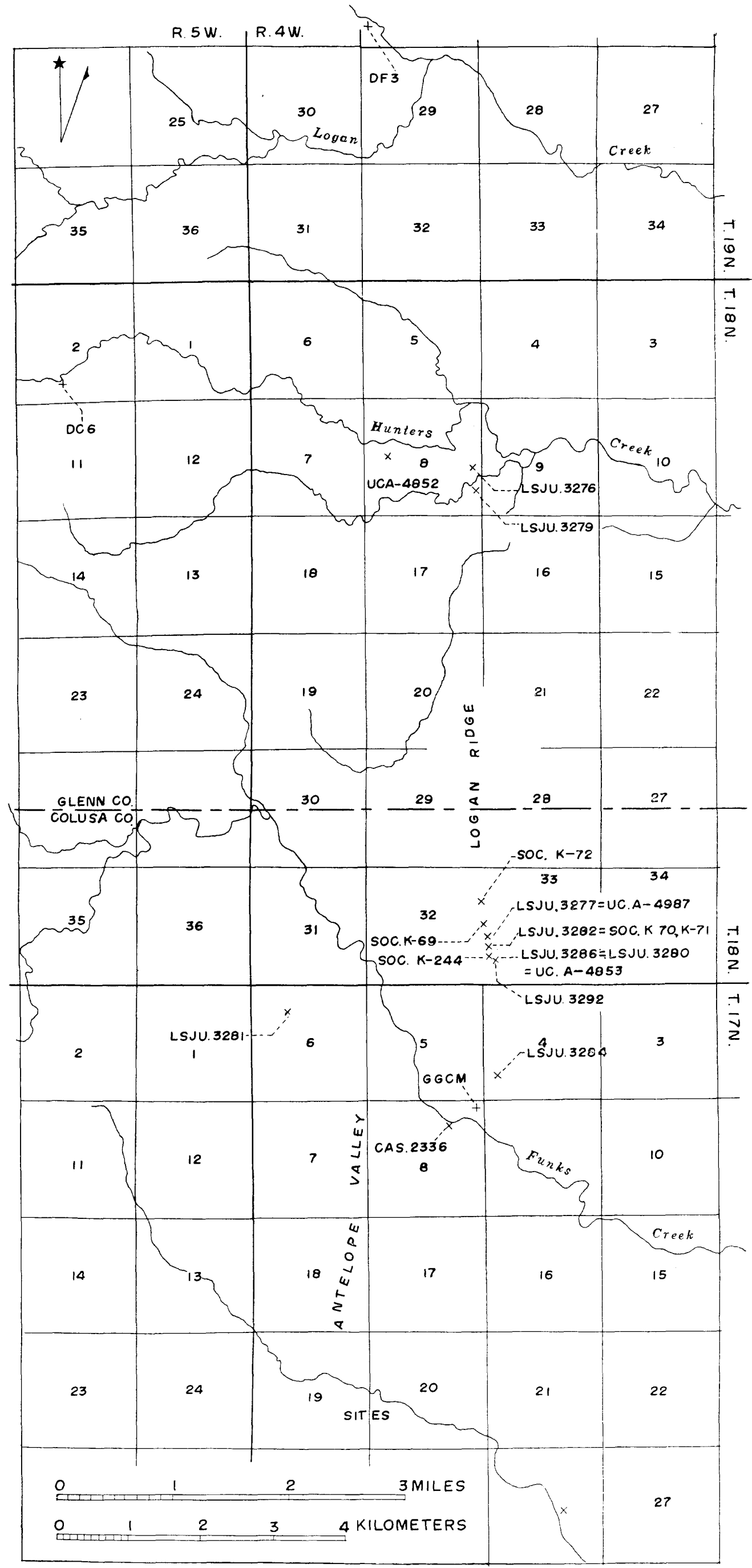

Fig. 8. Map of the Sites-Logan Ridge area, Glenn and Colusa Counties, west side of the Sacramento Valley, showing ammonite localities. KÜPPER's foraminifera localities are indicated with + . Compiled by T. Matsumoto from the data provided by LSJU., CAS., UC., and M. V. KIRK. 
LSJU. 3287, CAS. 1291, UC. A-4987, SOC. K-70, SOC. K-72, SOC. K-244A, and SOC. K-244B. The ammonites from them are:

Desmoceras (Pseudouhligella) dawsoni W HITEAVES

Pachydesmoceras colusaense (ANDERSON)

Beudanticeras [Brewericeras ?] cf. haydeni (GABB)

Hysteroceras varicosum (SOWERBY)

Mortoniceras sp.

Mortoniceras (Durnovarites) sp. aff. $M$. (D.) quadratum SPATH

Mortoniceras (Durnovarites) nodosocostatum (HOEPEN)

Neophylycticeras (?) sp.

Anagaudryceras cf. sacya (FORBES)

Idiohamites sp.

Pseudhelicoceras petersoni (ANDERSON) [=Turrilites petersoni

\section{ANDERSON]}

The assemblage is similar to that of the units (i) to (ii) of the Ono area, indicating the Upper Albian. The superjacent Venado sandstone is, however, probably Lower Turonian, so far as Inoceramus labiatus SCHLOTHEIM is reliable.* No positive evidence has been found for concluding that there is a stratigraphic gap at the base of the Venado formation in this place. KIRK discovered, at loc. SOC. K-69, very close to the localities of Upper Albian ammonites, immediately below the Venado sandstone,

Plesiovascoceras californicum (ANDERSON)

which indicates Lower Turonian. This is reasonable for the age of the Lower Venado sandstone and the subjacent part of the shale, but is very contradictory to the Albian ammonites. There must be some peculiar features either in geologic structure (e.g. a concealed thrust) or in sedimentation (e.g. a large slumping, as being interpreted by Robert BRowN and Ernest RICH, USGS. geologists-a talk at AAPG. meeting, 1959). I myself have no field evidence to settle the question, except for a suggestion of age from the contained ammonites.

Several kilometers west from Logan Ridge there is an upright anticline (called Sites anticline) and further west there is a gentle syncline. The syncline is occupied by a unit of sandstone, which belongs, as CHUBER has clarified from his accurate mapping, to the Venado formation. The anticlinal area and also the western flank of the syncline consist of a unit of shale ("Antelope shale") with some intercalated sandstone followed below by a unit of conglomerate and standstone and then another unit of thick shale with subordinate sandstone. The fossil records in this part can be described as follows:

(i) In the last mentioned shale unit CHUBER discovered some Albian species:

Beudanticeras sp.

Mortoniceras sp.

Inoceramus concentricus PARKINSON

* Dr. Jones has added more and better specimens of Inoceramus labiatus from the lower part of the Venado. 
(ii) At a locality on Stony Creek, from a shaly unit below a conglomerate, CHUBER and I collected a few ammonites:

Desmoceras cf. kossmati MATsumoto

Puzosia sp.

A fragment of an ornate ammonite, cf. Graysonites (?) sp.

These suggest lower Lower Cenomanian.

(iii) In the lower part of the "Antelope shale" equivalent on the western flank of the syncline, at locs. UC. A-4864 and CAS. 33725, occurred:

Desmoceras (Pseudouhligella) japonicum YABE

Puzosia sp.

Calycoceras cf. orientale MATsumoto, SAIto, and FukAdA

Calycoceras cf. spinosum (KossMAT)

The assemblage indicates Middle to Upper Cenomanian.

In the same "Antelope shale" on the eastern flank of the syncline (i.e. on the western flank of the Sites anticline), there are an ammonite locality, LSJU. 3281, and KüPPER's (1956) micro-fossil locality, DC6. The ammonite is:

Calycoceras cf. spinosum (Kossmat)

On the eastern flank of the anticline, in the main part of the "Antelope shale", there are two ammonite localities, CAS. 2336 and UC. A-4852, and KÜPPER's two other micro-fossil localities, GGCM and DF3. The ammonites are:

Calycoceras boulei CoLligNoN

Calycoceras cf. stoliczkai ColligNoN

The three species of Calycoceras indicate Middle to Upper Cenomanian. This is in harmony with KüPPER's (1956) conclusion from the pelagic foraminifera. (iv) At loc. CAS. 33726, an exposure on South Fork of Willow Creek, about 6 kilometers south of Fruto, top of the shale formation immediately below the Venado sandstone equivalent on the western flank of the syncline, CHUBER and I collected:

Mesopuzosia sp.

Tragodesmoceroides (?) sp.

Inoceramus labiatus SCHLOTHEIM

The last species occurs in abundance. It is a world-wide guide fossil of the Lower Turonian.

(v) At the basal part of the Venado sandstone at the same exposure, CAS. 33726, CHUBER and I collected another species:

Inoceramus ef. hobetsensis nonsulcatus NAGAO and MATSUMOTO

At loc. UC. A-4866, about 1 kilometer northeast of Fruto, on the western flank of the syncline of the Venado sandstone, occurred an ammonite:

Tetragonites cf. glabrus (JIMBO)

These two species suggest that the Venado sandstone in this synclinal area is probably Turonian.

Summarizing the above, in the area of the Fruto and Lodoga Quadrangles, 
the extensions of the formations of the Rumsey Hills-Cache Creek and adjacent area can be traced. As the rock units varies rapidly in thickness and in lithologic characters, it may be sometimes difficult to refer a given rock exposure to any of the formations defined in the type section. Even if this can be done by careful mapping, the boundary of rock units may go oblique to the boundary of time-stratigraphic units. The available records of ammonites are complementary between the two areas. Certain species among them are good guide fossils for world-wide, as well as provincial correlation. Of course the above data are far from perfect, but it is hoped that the active field work now being undertaken in this general area will furnish clearer knowledge of stratigraphy and more paleontological material.*

(c) Putah Creek and vicinity, in southern Yolo, northern Solano, and eastern Napa Counties.-KIRBY (1943) presented a route map and a measured section along the Putah Creek, where he applied the subdivisions, established in the type sections further north. Between Putah Creek and the type sections there is a geologically unmapped area, although topography gives a rough idea of the geology. Since the lithology can change from place to place, we need paleontologic evidence even for local correlation. The available ammonites from this area are still insufficient, but are better than nothing. I briefly explain their localities, referring to the stratigraphic section (Text-fig. 9).

(i) A shale unit including the locality LSJU. 3190, where Dr. TALIAfERRo discovered a large ammonite, which is now preserved in Stanford University. That ammonite is in my identification

Mortoniceras cf. kiliani (LAsswiTZ)

which indicates Upper Albian.

There is a considerable distance between the locality of Mortoniceras and that of a conglomerate which KIRBY regarded as the base of the Venado formation, but the exposure along the creek seems to be discontinuous. The shaly unit which comes directly below that conglomerate was indicated by KIRBY as the top member of the "Shasta series", but it might be the lower part of the Upper Cretaceous. Unfortunately good indices of age have not yet been found from these doubtful, intervening parts.

(ii) Next comes what KIRBY called the Venado formation. Its thickness is $\mathbf{5 7 6}$ meters (1890 feet), which is thin as compared with that in the northern section. It consists primarily of sandstones, but conglomerates occur at several horizons in the lower part, and siltstones are intercalated in subordinate amount. From one of the conglomerates at locality UC. B-2040, very close to the country boundary, a very important ammonite was obtained on the occasion of a geological excursion of a class of University of California, 1951. It is, according to ImLAY,

* After I completed the manuscript, I have received more specimens on loan from Dr. Jones and Mr. Chuber. Among them Baculites cf. chicoensis TraSk is noteworthy. The sandstone containing $B$. cf. chicoensis was assigned by JoNES to the Sites formation in Lodoga-Fruto Quadrangles, but I doubt if it could be the Guinda sandstone. 


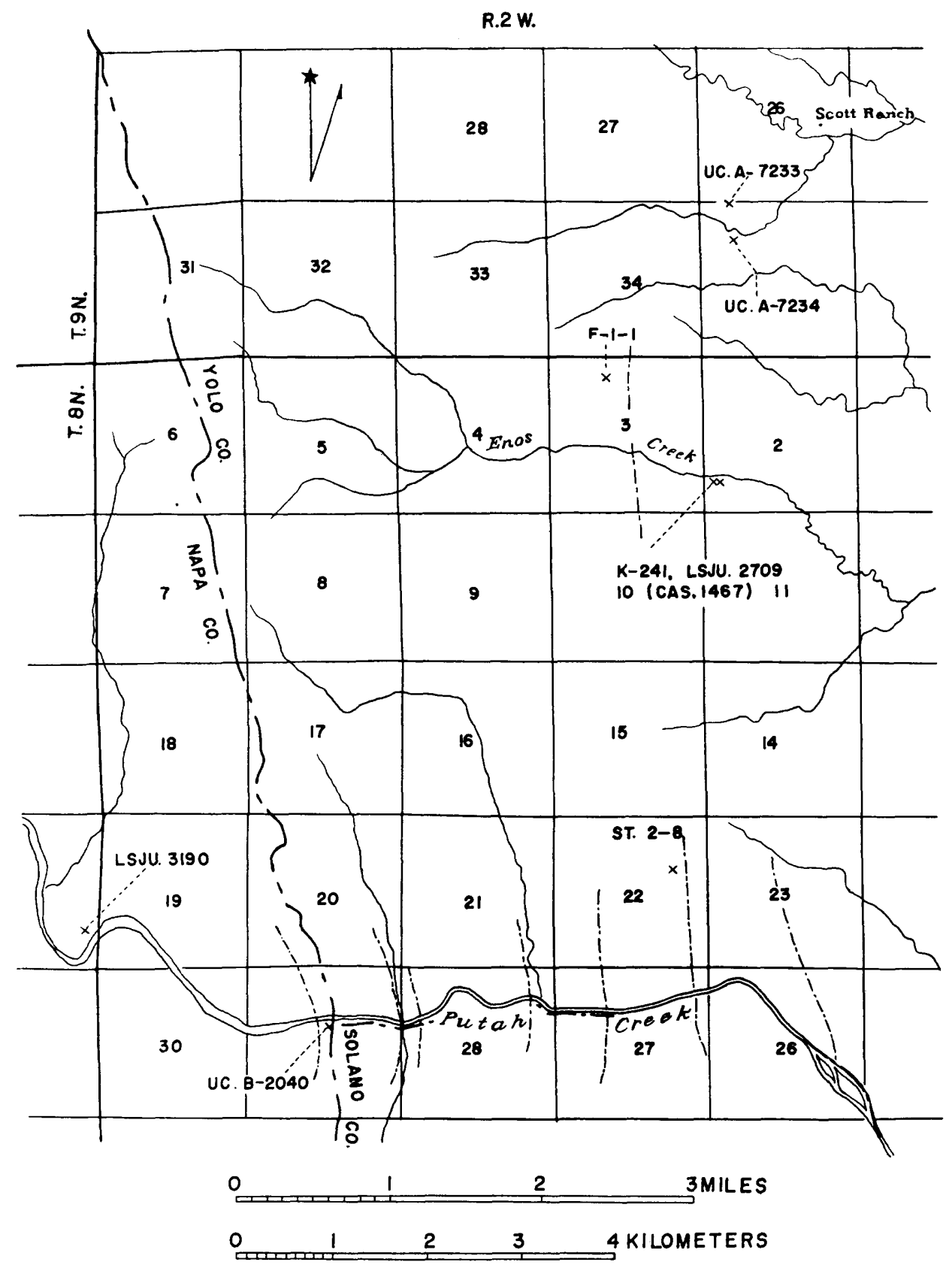

Fig. 9. Map of the Putah Creek and adjacent area, Yolo, Napa, and Solano Counties, west side of the Sacramento Valley, showing ammonite localities. Compiled by T. MATsumoto from the data provided by LSJU., UC., SOC. (with K-number), and Messrs. Stewart ChUBER and C. W. Cline (with ST and F-numbers). A boundary of KIRBY's units is indicated by a broken line. 
Romaniceras sp. and in my identification,

Romaniceras aff. inerme (DE GROSsOUVER, 1898) [=Acanthoceras bizeti DE Grossouvre, 1901]

On the occasion of another paleontological excursion of the same university, February, 1958, poorly preserved ammonites were added to the collection from the same member

Tetragonites $\mathrm{sp}$. indet.

Mesopuzosia (?) sp. indet.

The Romaniceras suggests that KIRBY's Venado in Putah Creek section is Turonian. This sandstone unit is followed successively by:

(iii) A unit of predominant shales, with intercalated sandstones, 268 meters $(880$ feet)

(iv) A unit of predominant sandstones, with intercalated shales, 1200 meters (3965 feet)

(v) A unit of predominant shales, with intervening sandstone in the middle, 789 meters (2589 feet)

(vi) A unit of predominant sandstones, with subordinate shales, 907 meters (2975 feet)

KIRBY referred (iii) to Yolo, (iv) to Sites, (v) to Funks, and (vi) to Guinda formations, but no ammonites have been found in them.

(vii) The highest unit of the Cretaceous in Putah section is 794 meters (2606

feet) of shales with subordinate sandstones, which KIRBY referred to the Forbes formation. It is overlain unconformably by Eocene beds.

CLINE has recently discovered ammonites from a locality, "St. 2-8, 1200 feet west, 1850 feet south from the northeast corner of sec. 22, T. 8 N., R. 2 W., and another, "F-1-1", 1950 feet east, 700 feet south, from the northwest corner, sec. 3 , T. 8 N., R. 2 W." I have identified:

\section{Desmophyllites diphylloides (FoRBES)}

Baculites cf. inornatus MEEK

The locality data are provided by Messrs. ClINE and CHUBER and the specimens, which I borrowed, were returned to Mr. Cline. According to them the two localities are in the upper part of the Guinda formation near its top. The age suggested by the two species is Campanian, but I cannot tell exactly its relation with the age of the basal fossiliferous part of the Forbes formation in the Rumsey Hills.

(viii) There are several ammonite localities north and south of Putah Creek. Some of them are evidently higher than the above mentioned two localities. I cannot tell at present whether or not they could be included in the uppermost part of the Forbes formation, because the available stratigraphical records are insufficient. The fossils are mostly contained in limestones, which may or may not be lenticular beds.

(A) Localities LSJU. 2709, SOC. K-241, CAS. 1467, and CAS. 1467A, all in Enos Canyon, Yolo County, containing the following species:

Neophylloceras ramosum (MEEK) 
Desmophyllites diphylloides (ForBes) [=Desmophyllites yoloensis

ANDERSON, 1958]

Hauericeras sp.

Metaplacenticeras pacificum (SмITH)

Gaudryceras cf. denmanense WHITEAVES

Pseudoxybeloceras (?) lineatum (GABB)

Inoceramus subundatus MEEK

The assemblage suggests Upper Campanian, being comparable with the Metaplacenticeras-bearing beds of the Hornbrook area, Arroyo del Valle, and the Santa Ana Mountains.

A poorly preserved specimen comparable with Metaplacenticeras pacificum came from another locality, UC. A-7237, and Gaudryceras cf. denmanense Whiteaves from loc. CAS. 1343, both in Pleasant Valley, Solano County.

(B) Locality UC. A-7234, on ScoTT ranch, Yolo County, which is interpreted as representing a higher horizon than the Enos Canyon localities. The identified ammonites are:

Phyllopachyceras forbesianum (D'ORBIGNY)

Desmophyllites sp.

Anapachydiscus [or Menuites] sp. juvenile

Baculites rex ANDERSON

Baculites (?) teres (FoRBEs)

The suggested age is uppermost Campanian or Lower Maestrichtian, determined by comparison to the faunas of the Coalinga and adjacent areas to be mentioned later.

\section{Panoche Hills, on the west side of the San Joaquin Valley}

This is the type area of the Panoche and Moreno formations of R. ANDERson and R. PACK (1915). At the suggestion of Professor Schenck, Max B. PAYNe did an excellent work on the stratigraphy of the latter, a result of which was published in 1951. D. W. Sutron studied the former as a Master degree work in Stanford, but did not publish the results. PAYNE succeeded SUTTON's work, and is completing the stratigraphy of Panoche Hills.

At Professor SchencK's suggestion, I joined PAYNe in collecting ammonites from the subdivisions of PAYNE and SUTTON. A tremendous thickness of strata is well exposed in the area, but in the previous collections there were very few ammonites. Indeed the sedimentary environment does not seem to have been favorable for fossil cephalopods, except at a few places. Professor Graham, Dr. D. L. Jones, M. B. PAYNE,* and I discovered some new mega-fossil localities, but the data are still insufficient. In parallel with our work, Lewis MARTIN studied micro-fossils, which were obtained from the measured sections of this area. This may be the first attempt in the Cretaceous of California to tie up intimately micro-fossils with ammonites in up-to-date and well organized procedure.

* D. K. CLARK has recently added one more locality. 


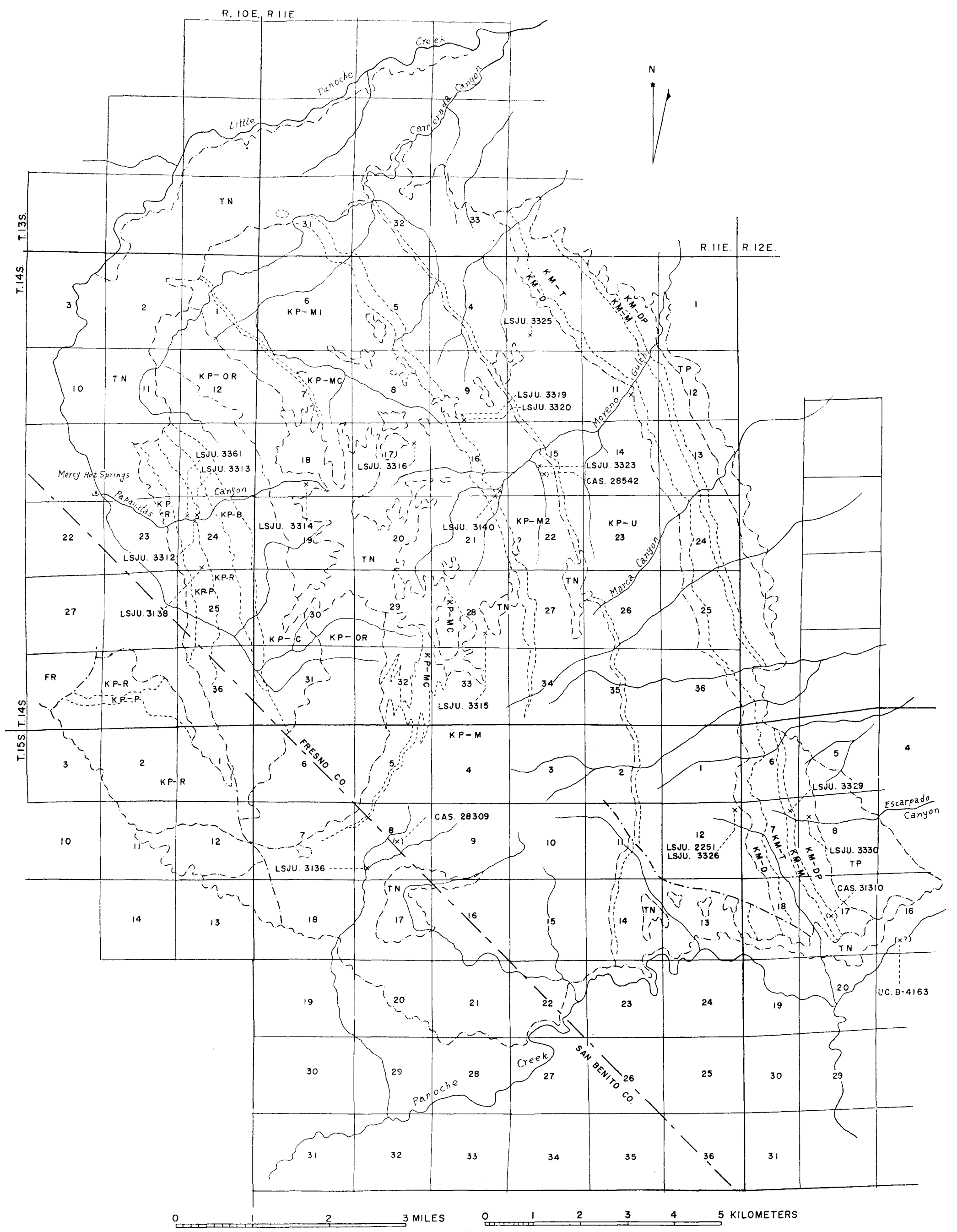

Fig. 10. Map of the Panoche Hills, Fresno and San Benito Counties, west side of the San Joaquin Valley, showing ammonite localities. Data of D. W. Sutton, M. B. PAyne, T. Matsumoto, etc. provided by LSJU., CAS., and UC. Geological outline provided by PAYNe \& SUtTon. FR: Franciscan group; KP: Panoche group, comprising KP-R: Redil formation, KP-P: Papanatas conglomerate, KP-B: Benito sandstone, KP-C: Ciervo shale, KP-OR: Ortigalita sandstone, KP-M: Marlife formation, KP-M1: Lower Marlife shale, KP-MC: Carnerada conglomerate, KP-M2: Upper Marlife shale, KP-L: Llanada sandstone, KP-T: Television sandstone, and KP-U: Uhalde formation; KM: Moreno formation, comprising KM-D: Dosados member, KM-T: Tierra Loma shale, KM-M: Marca shale, KM-DP: Dos Palos shale; TP: Older Tertiary; TN: Younger Tertiary. 


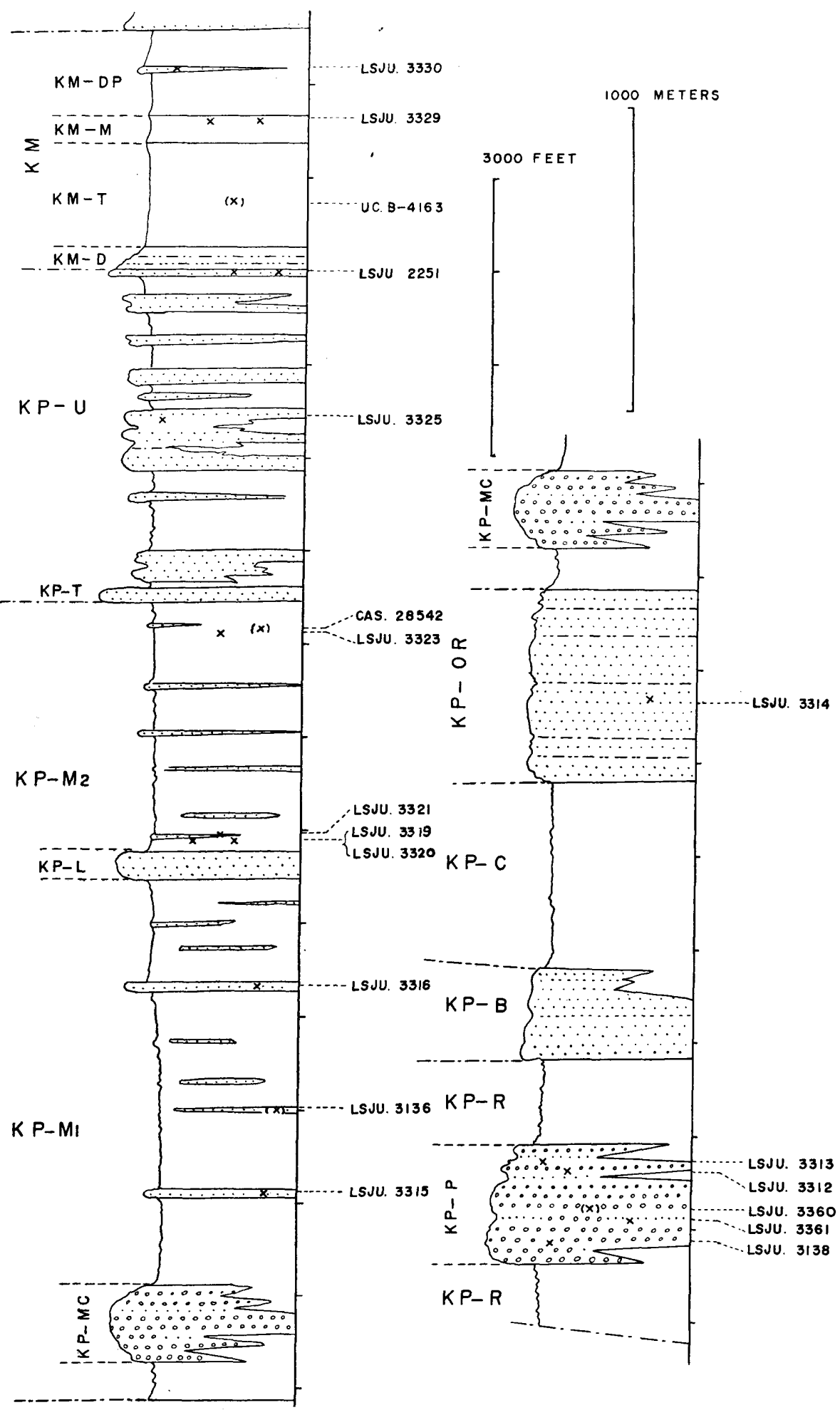

Fig. 11. Generalized columnar section of the Cretaceous deposits in the Panoche Hills, west side of the San Joaquin Valley, indicating the stratigraphic positions of ammonite localities. For symbols of formational names see the explanation of Fig. 10 . 
The Panoche formation is better called the Panoche group, because it is proved to be a major unit of long time interval, consisting of many members and formations of varying lithology and of great thickness.

The geographical and stratigraphical positions of ammonite localities in the Panoche Hills can be concisely shown in an outline geological map (Fig. 10) and a columnar section (Fig. 11). They are briefly explained below, referring to the members and formations as defined by PAYNE (1951) and PAYNE and SutToN (1959 MS), with slight modification. The description is in ascending order.

\section{Franciscan group \\ - fault relation - \\ Panoche Group}

I. Redil formation.--Greenish dark grey shales with frequent intercalation of thin layers of calcareous rock and sandstone, over 600 meters thick. No ammonite has been found in shales themselves. In the middle part of the formation there is a lentil of conglomerate called Papanatas conglomerate. It consists primarily of boulder-cobble conglomerates, with subordinate sandstones. Angular to subrounded pebbles of Redil-like rocks are contained in significant quantity. This may, however, be evidence of contemporaneous erosion, because the conglomerates are rapidly thinning away into sandstones and shales. The boulders and cobbles are mostly granitic and other igneous rocks. The conglomerate is about 215 meters thick in the type Papanatas section, but it seems to thin out rapidly, interfingering with shale and sandstone. Ammonites, sometimes associated with other mollusks, have been discovered at several localities, but always from nodule-like boulders of calcareous sandstone or siltstone. Some of them might be calcareous nodules in situ, but others are probably derived nodules or boulders from unknown, but presumably not far distant, sources. They may or may not be the products of contemporaneous erosion. The contained species are

At loc. LSJU. 3360 (coll. D. L. JoNES) :

Leconteites lecontei (ANDERSON)

At loc. LSJU. 3138 (coll. S. W. MULLER and D. W. SUtToN) :

Beudanticeras [Brewericeras ?] cf. hulenense ANDERSON

At loc. LSJU. 3361 [=TM. 106] (coll. T. Matsumoto) :

Beudanticeras (?) sp.

At loc. LSJU. 3312 [=TM. 201] (coll. M. B. Payne and T. Matsumoto):

Bhimaites sp.

Lechites sp. aff. L. gaudini (PICTET and CAMPICHE)

Hamites (?) sp.

At loc. LSJU. 3313 [=TM. 109] (coll. T. MATsumoto) :

Desmoceras (Pseudouhligella) sp.

Hamites (?) sp.

The ammonites suggest Middle to Upper Albian. It is noted that the above localities are arranged in ascending order. Dr. POPENOE kindly looked through 
the molluscan shells of the last locality and expressed the opinion that the age of the fossils is not younger than Cenomanian (oral communication). If the ammonites are derived fossils from an older formation, the Papanatas conglomerate is not younger than Albian. If they came from a nearly contemporaneous unit of laterally changing lithology, the conglomerate would be Middle to Upper Albian, but possibly Lower Cenomanian near its top. We need more evidence from the surrounding rocks as well as from the conglomerate itself.

IIA. Benito sandstone.-Greenish grey sandstones, bearing granules and shellfragments, at the base but no ammonite; about 240-460 meters thick.

IIB. Ciervo shale.-Shales intercalating thin layers of sandstones and calcareous shales, containing compact, limy nodules. The shale is dark grey, with a characteristic, bluish-greenish tint. It resembles Yolo shale of west Sacramento Valley, but I failed to discover any ammonites to prove the correlation. About 800 meters thick.

III. Ortigalita sandstone, 240-800 meters. Sandstones predominant, with some intercalated sandy shales. This unit resembles lithologically the Sites formation. From loc. LSJU. 3314 [=TM. 131], from a granule-bearing, very coarse sandstone about 60 meters above the base of this unit, I found a few fragments of shells, in which there is a Lewesiceras-like ammonite.

IV. Marlife formation.-Dark grey shales with frequent interbeds of sandstones. This is a unit of great thickness, about 2600 meters, being subdivided into two parts, lower and upper. Sandstones go and come through the entire outcrop, but the sandstone lentil at the midst of the unit is more continuous and thicker than others, being characterized by a large cannon ball structure. This lentil, called the Llanada sandstone with average thickness of 100 meters, marks the base of the upper member.

IVA. Lower Marlife shale.-The shale when weathered is characteristically brownish. In the lower part a lentil of cobble-boulder conglomerate, called Carnerada conglomerate, is intercalated with the shale and sandstone. Granite, quartz-porphyry, and other igneous rocks are predominant in the cobbles and boulders. At several levels beds of predominant sandstones, often with a cannon ball structure, are intercalated. Fragmentary fossils are embedded as patches in the sandstones. The localities are LSJU. 3315 [=TM. 210], LSJU. 3136, and LSJU. 3316 [=TM. 31]. The characteristic species is

\section{Baculites schencki MATSUMOTO}

as in Member IV of the Redding formation, the basal member of Chico formation (s.s.), and the Funks shale. At the first locality, it is associated with

Inoceramus cf. uwajimensis YEHARA.

Thus the Lower Marlife member is best referred to the Coniacian. Accordingly the almost barren units III and II are probably the equivalents of the Turonian and Cenomanian.

IVB. Upper Marlife shale.-In its lower part, about 46 meters stratigraphically above the top of the Llanada sandstone, there is a prolific layer, represented by the localities LSJU. 3319 [=TM. 11] (first discovered by J. J. GrAHAM) and 
LSJU. 3320 [=TM. 14]. The identified species are:

Anapachydiscus sp. juvenile

Anagaudryceras yamashitai (YABE)

Scalarites (?) sp.

Baculites capensis WooDs

The last species occurs abundantly. It is also associated with

Inoceramus naumanni YoKOYAMA

Inoceramus cf. amakusensis NAGAO and MATSUMOTO

and several other molluscan species.

From this assemblage, as well as from the stratigraphic position, the lower part of the Upper Marlife shale is best assigned to the Santonian, being correlated with the second unit of the Chico formation (s.s.).

There are a few more beds of sandstone in the middle of the member in which fragmentary shells are scattered, but no good age indicators have been found.

In the upper part of the Upper Marlife, above a bentonite layer, fossiliferous limy nodules are contained in the grey siltstone, as represented by the exposures, CAS. 28542 and LSJU. 3323. The identified species are:

Neophylloceras garganteum (ANDERSON)

Pachydiscus buckhami UsHeR

[=Parapachydiscus panochensis ANDERSON, 1958, holotype]

Baculites cf. inornatus MEEK

Inoceramus sp. (many fragments of a large form)

The assemblage of the upper part of the Upper Marlife indicates the Campanian rather than the Upper Santonian.

V. Uhalde formation.-About 1000 meters. The basal part, about 30 meters is defined by a member of predominant sandstone, called the Television sandstone, persistent throughout the area. It is weathered to a dark color. The main part of the Uhalde formation is shales with frequent interbedded sandstones.*

In a sandstone in the middle part I found the impressions of Halymenites sp., which are close to those in the Fox Hills sandstone of the Western Interior and also in the Maestrichtian sandstones in Mexico and Japan. While the sandstones are of greywacke type in the main part, they are less muddy at the top of the Uhalde formation, containing rounded pebbles and remains of shells. It is still to be settled whether this sandstone unit should be placed at the top of the Panoche group or at the base of the Moreno formation. For the time being I follow PAYNE who regards it as the top member of the Uhalde formation. The mega-fossil locality LSJU. 2251 has already been reported by PAYNE (1951), which is equal to LSJU. 3326 [=TM. 2]. The revised names of ammonites are:

Glyptoxoceras sp.

Diplomoceras sp.

* D. K. CLARK has recently discovered a baculitid species from a locality in the Uhalde formation, but I refrain from further discussion about it untill his work is completed. 


\section{Baculites columna MoRToN}

The last species is known in the Prairie Bluff chalk of Alabama and the Corsicana marl of Navarro group of Texas (STEPHENson, 1941). Therefore the sandstone at the top of the Panoche group is very possibly referable to the Lower Maestrichtian.

Moreno formation.-Consisting primarily of brownish to purplish, dark grey shales, rich in organic remains, 550-975 meters thick. The subdivisions in ascending order are:

A. Dosados sand and shale member, 60 meters at type locality. No ammonite has been found from this unit. A plesiosaur is known.

B. Tierra Loma shale member, 350 meters at type section, including Mercy sand lentil (55 meters thick at type locality) in the middle. Several localities of reptiles-mosasaur, plesiosaur, and trachodon are known. An ammonite locality, UC. B-4163, is recorded as belonging to this member. I have identified:

Diplomoceras (?) sp.

Eubaculites cf. ootacodensis (STOLICZKA)

C. Marca shale member, 91 meters. The hitherto known diagnostic fossils are foraminifera, Siphogenerinoides whitei, and reptiles, Kolposaurus tuckeri, etc. From the white calcareous concretions at localities LSJU. 3327 [=TM. 3] and LSJU. 3329 [=TM. 204] PAYNE and I discovered:

Neophylloceras hetonaiense Matsumoto

Phyllopachyceras sp.

Diplomoceras sp.

Baculites rex ANDERSON

Inoceramus sp.

This is stratigraphically the highest ammonite bearing member in California. B. rex ANDERSON occurs commonly. It is represented by smaller specimens than the holotype and other examples from the lower horizons. Loc. CAS. 31310 belongs to the same member, whence came:

Neophylloceras hetonaiense Matsumoto (a form with umbilical bullae)

D. Dos Palos shale member, 275 meters. We could not find any cephalopoda, except for a doubtful, belemnite-like object from the Cima sand lentil, which was sent to JELETZKY and was considered by him as doubtful (personal communication). From the Cima sand PAYNE reported Flabellum sp., a solitary coral which is rare in Cretaceous rocks. From the foraminifera the Dos Palos shale has been referred to the Paleocene or so-called Danian (GoudKofF 1945, PAYNe 1951, MARTiN's personal communication for at least the upper part of the member).

Overlying: Eocene Lodo shale formation, with glauconite sand.

The above listed ammonites from the Moreno formation are relatively long ranged, but Baculites rex ANDERSON and Eubaculites ootacodensis (STOLICZKA) are the youngest representatives of the Baculitidae in California. Neophylloceras hetonaiense MATSUмото, especially its tuberculate variety, is common in the Neohetonaian $[\doteqdot$ Maestrichtian] of Japan. The conclusion from the available 
ammonites is that the main part of the Moreno formation is probably Maestrichtian, but that there are no diagnostic elements of cephalopoda to define accurately the Cretaceous-Tertiary boundary in this area. Unless true belemnites or other Cretaceous guide fossils can be proved to occur as indigenous fossils in the Dos Palos formation, the determination of its Paleocene age by micropaleontologists should be accepted.

\section{Several areas, north of the Panoche Hills, west side of the San Joaquin Valley}

Broadly speaking, the Cretaceous sediments of the Panoche Hills extend northwest and southeast along the west side of the San Joaquin Valley, but the outcrops are divided by the covering of the Cenozoic sediments into several areas. (a) Cretaceous area of Ortigalita Peak Quadrangle.-This is immediately north of the Panoche Hills, being separated from the latter by the Cenozoic sediments of Little Panoche valley. Despite the interrupted exposure and lateral change of facies, the formational units established in the Panoche Hills can generally be traced northward.

BRIGGS' (1953) published map, with explanatory text, is very useful. According to him, the southwestern part of the quadrangle is occupied by the Franciscan group and associated igneous rocks, which are in fault contact with unmistakable Cretaceous. The Cretaceous strata incline homoclinally to the northeast and are overlain by Paleocene to Eocene strata on the eastern edge of the hills. BRIGGS indicated in ascending order the three major groups of Cretaceous strata:

Wisenor formation

Panoche formation (better called Panoche group)

Moreno formation

The Wisenor formation, consisting of shales and fine-grained sandstones, was assigned by BRIGGs to the Lower Cretaceous on account of the "fossils indicating the Horsetown stage". No specific names and no locality were indicated by him, and I myself had no opportunity of seeing the specimens.

The Panoche group in this area consists of about 9000 meters of "siltstone and shale interbedded with thin flaggy lime-cemented subgraywacke sandstones" and also of some massive sandstones and conglomerates. BRIGGs' geological map clearly shows that the conglomerates thin out rapidly, but that they frequently occur in the basal and the middle parts. They may correspond to the Papanatas and the Carnerada conglomerates of the Panoche Hills.

The available evidence of fossils for age correlation of the lower and middle parts of the Panoche group is insufficient in this area. Only one ammonite locality in the middle part (about 4900 meters stratigraphically below the top of the Panoche group) was mentioned by BRIGGs. That is UC. A-6621, from which I identify

Baculites cf. yokoyamai TokUNAGA and SHIMIZU* and a poorly preserved scaphitid. B. yokoyamai TokunAGA and SHIMIzU is

\footnotetext{
* Read Baculites cf. B. yokoyamai for Baculites aff. B. yokoyamai in the explanation of
} Fig. 26 (page 118) in Part I of this paper. 
abundant in the Coniacian of Japan and is very possibly identical with or at least closely allied to Baculites besairiei CoLLIGNON from the Lower Senonian of Madagascar. It is rare in California, but its probable example occurs in Member IV of the Redding formation. Therefore the middle part of the Panoche group in Ortigalita Peak Quadrangle, including loc. UC. A-6621, is most probably referable to the Lower Senonian.

The upper part of the Panoche group consists of members and lentils of massive sandstones alternating with siltstones or shales. It may approximately correspond to the Uhalde formation of the Panoche Hills.

There are debates about the Panoche-Moreno boundary. PAYNE (1951) presented a fine map and correlation charts across the hills and creeks from the type locality of Moreno, through Ortigalita and Los Banos Creeks up to Garzas Creek. His scheme, based on cartographic and micropaleontologic grounds, differs to a considerable extent from that of BENNISON's (unpublished, but often quoted). In the Ortigalita Peak Quadrangle BRIGGS' boundary does not deviate much from PAYNE's, but on Ortigalita and Salt Creeks BRIGGS' boundary is shifted somewhat westward, i.e. stratigraphically downward, compared with PAYNE's. I myself have no positive evidence for or against any of the three views, except for some suggestions from the ammonites which were at my disposal.

There is a considerable number of mega-fossil localities in this questionable part. The ammonite localities among them are all below PAYNE's boundary line of Panoche and Moreno, being distributed at several stratigraphic levels within a thickness of about 900 meters, i.e. within the equivalent of the Uhalde formation. In Wildcat Canyon and its North Fork there are four UC. localities (Text-fig. 12) discovered by the Paleontology class 137, 1953 and A. BENNison. Three of them, UC. A-9753, UC. A-9754, and UC. A-3827, belong to the second silty unit about 460 meters below the top of Panoche, which is sometimes called "Pachydiscus silt". The identified species is

Anapachydiscus cf. californicus (YABE)

which probably indicates a Campanian, rather than Maestrichtian age (see systematic descriptions in Part II).

Another locality, UC. A-3826, is in the next higher siltstone unit, below the top sandstone unit of the Panoche group. The identified species is

Glyptoxoceras indicum (FORBES)

which suggests, from its occurrence in the Valudayur beds of India, the uppermost Campanian to Lower Maestrichtian.

On Ortigalita Creek and another creek south of it (Text-fig. 13), there are four localities, UC. B-4149, CAS. 29656, CAS. 30551, and CAS. 29121. The first locality is in a bed of sandstone, containing in small lenses pebbles and shell-bearing, calcareous concretions, which was regarded as a top bed of Panoche group in BRIGGS' map but placed by PAYNE at a position about 300 meters stratigraphically below the top of the Panoche group. The species which I have identified are: 
Pachydiscus cf. egertoni (FoRBES)

Anagaudryceras mikobokense CoLLIGNON

Gaudryceras (Vertebrites) cf. kayei (FoRBES)

Glyptoxoceras (?) subcompressum (FORBES)

The assemblage suggests the Lower Maestrichtian or the uppermost Campanian. The second locality is in another pebbly sandstone which probably falls within the Moreno formation of BRIGGS' map but can be referred to the top of Panoche of PAYNE's map. The ammonites, discovered by BENNIson, are:

Neophylloceras hetonaiense MATsumото (a variety with umbilical bullae)

Anagaudryceras cf. mikobokense CoLlignoN

$$
\text { [=Lytoceras (Gaudryceras) aureum ANDERSON, holotype] }
$$

Glyptoxoceras cf. largesulcatum (FORBES)

[=Diplomoceras mercedense ANDERSON, holotype]

Exiteloceras (?) ortigalitense (ANDERSON) (holotype)

The assemblage suggests, if not definitely indicates, the Lower Maestrichtian. The other two localities are in the area of the Moreno formation in BRIGGs' map but still in the upper part of the Panoche group in PAYNE's map. The ammonites are:

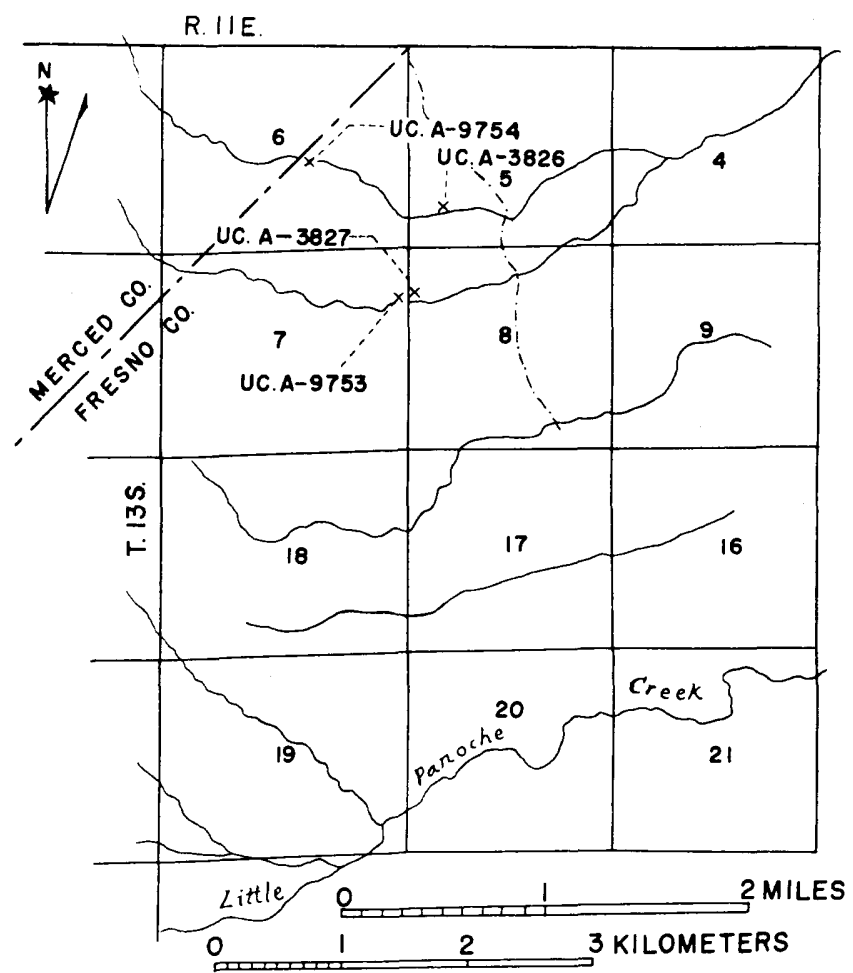

Fig. 12. Map showing ammonite localities along Wildcat Canyon, Fresno County, west side of the San Joaquin Valley. Data provided from UC. A broken line indicates the Panoche-Moreno boundary of BRIGGS, 1953. 


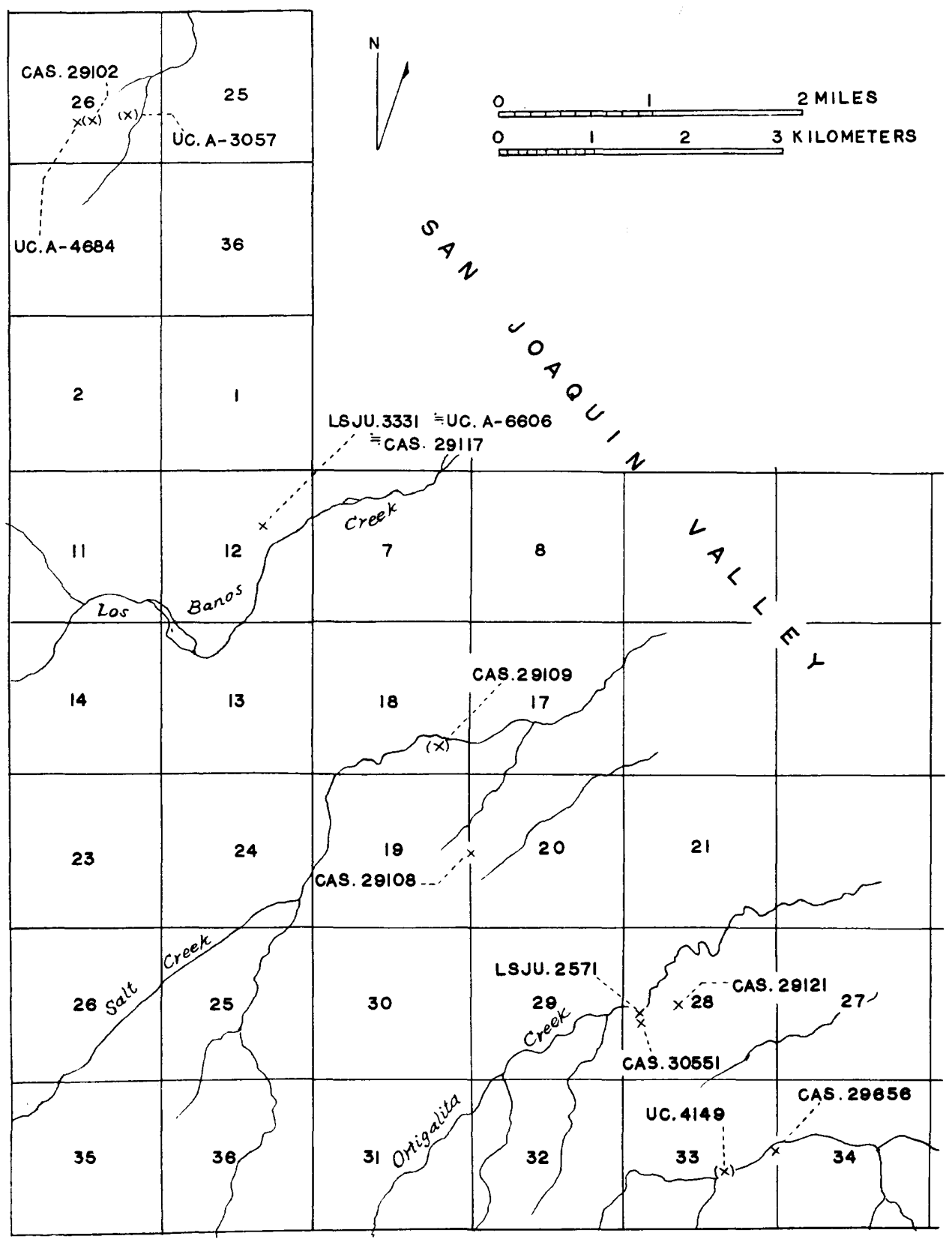

Fig. 13. Map of the Upper Cretaceous area in the northern part of Ortigalita Peak and southwestern part of Volta Quadrangles, Merced County, west side of the San Joaquin Valley, showing ammonite localities. Data provided from CAS, and UC. 


\section{Pachydiscus ganesa (ForBes) [possibly immature of Pachydiscus egertoni (FORBES)] \\ Diplomoceras sp.}

They suggest the Lower Maestrichtian or the uppermost Campanian.

On Salt Creek (Text-fig. 13) there are two ammonite localities, CAS. 29108 and CAS. 29109, discovered by A. BENNIson. They are again in a pebbly, calcareous sandstone, which falls in the highest part of Panoche in BRIGGS' map, but was referred to the Moreno by ANDERson (1958, p. 182). The species in my identification are:

Neophyhlloceras ramosum (MEEK) (a large variety ?)

[=Phylloceras pachecoense ANDERSON, holotype and other examples]

Pachydiscus cf. ootacodensis (STOLICZKA)

Diplomoceras sp.

Although ANDERSON (1958, p. 182) regarded this bed as the same horizon as that of CAS. 29656, mentioned above, his correlation was by no means supported by sound grounds. I rather think PAYNE's mapping to be reasonable, because the localities come fairly well below the top of his Panoche and because the assemblage suggests the Upper Campanian rather than the Maestrichtian.

The apparently highest Cretaceous outcrop along the section of Los Banos Creek (Text-fig. 13) is a unit of massive sandstone, containing pebbly, fossiliferous layers. It is represented by localities LSJU. 3331 [=TM. 301], CAS. 29117 [=CAS. 28310], CAS. 29118, and UC. A-6606. It was referred by BenNison to the middle part (B) of the Quinto silt member (see PAYNE, 1951, pl. 2), but PAYNE put it considerably below the top of the Panoche. Actually the higher Cretaceous rocks are not well exposed here, owing to the covering of the younger Cenozoic Tulare formation. Although Glycymeris and other shells occur abundantly, ammonites are quite rare. I have recognized only a poorly preserved specimen of

Anapachydiscus (?) sp.

from UC. A-6606, in the collection of BRIGGS, who considers this bed as belonging to the upper part of the Panoche group.

In Volta Quadrangle (7.5 minute series) which adjoins to the north of Ortigalita Peak Quadrangle, there are a few ammonite localities, UC. A-4684, UC. A-3057, and CAS. 29102 (Text-fig. 13). They are on the hill north of Los Banos Creek, where exposures are poor, owing to the covering of younger sediments. They were referred to the Garzas sand member by BENNison (see PAYNe, 1951, pl. 2), but PAYNE considers that they may be floats, derived from a bed higher than the Garzas sand of type Garzas Creek. As I did not visit the localities, I cannot offer any comments about the field relations. But I should like to call attention to the ammonoid species from these localities. They are:

Tetragonites cf. popetensis YABE

Baculites columna MoRTON

Baculites (?) sp. aff. B.teres (FoRBEs)

The second species is diagnostic and occurs also in the sandstone at the top of 
the Panoche group of Panoche Hills. The suggested age is Lower Maestrichtian. (b) Pacheco Pass Quadrangle.-A valley along the Pacheco Pass highway separates the Cretaceous hills of the Ortigalita Peak Quadrangle from those of the northern two thirds of the Pacheco Pass Quadrangle. Although the general geological conditions are similar in the two areas, the actual tracing of the formational units from one area to the other is not easy.

Quinto, Mustang, and Garzas Creeks (Text-fig. 14) are in Pacheco Pass Quadrangle, from which came BENNIson's formational names. It was regrettable that his geological map and stratigraphical columns were not published, but his formational names have been frequently cited. PAYNE (1951) gave a geological map and stratigraphic sections for a higher part of the Cretaceous just subjacent to the Lower Tertiary. According to him the equivalent of the true Moreno is lacking owing to the overlapping of the Eocene sediments. BENNISON's members, Mustang shale, Quinto silt, Garzas sand, and Volta sand in ascending order, have all been regarded by some authors (e.g. ANDERson, 1958 , p. 56) as belonging to the Moreno formation. A still greater thickness of strata lies below this part and there are ammonite localities at various levels, that could give control for age correlation. PAYNE and I visited Quinto and Garzas Creek to look through the sequence, but our visit was too short for precise measurements of the sections and for obtaining good ammonites from the measured sections. Mr. F. A. SHILling is now engaged in the geological mapping of the quadrangle. He is sending me some ammonites of his collection. I hope he will complete the work and publish a refined scheme of stratigraphic classification and correlation. The following is a preliminary sorting of the scattered records of ammonites.

(i) The lower part of the section along Quinto Creek consists of about 900 meters of conglomerates which resemble lithologically the Papanatas conglomerate of the Panoche Hills. Below this conglomeratic unit is exposed a narrow belt of shales, which, in turn, is probably in fault contact with the green rocks and meta-sediments of the Franciscan complex. I could not find any ammonite from these parts, but TAFF, HANNA, and Cross in 1934 discovered at loc. CAS. 27858 an ammonite from the conglomerate. It is, in my identification,

$$
\begin{aligned}
& \text { Turrilites costatus LAMARCK [ = Turrilites pachecoensis ANDERSON, } \\
& \text { holotype }]
\end{aligned}
$$

which indicates the Cenomanian.

SHILlING found poorly preserved ammonites and a fragmentary Inoceramus (resembling $I$. anglicus WooDs) from a shale below the conglomerate.

(ii) The conglomerate is overlain by a unit of shales with interbedded sandstones and with the second conglomerate in the middle. This is about 425 meters thick and resembles in its bluish, greenish grey color the upper Redil shale of the Panoche Hills. I failed to find good mega-fossils in this unit. In the stream valley of Garzas Creek, in a calcareous sandstone at loc. CAS. 31131 [= ? CAS. 33719], ANDERson, MCCoY, and BENNison discovered several important specimens. From the topography this locality could be judged to be 


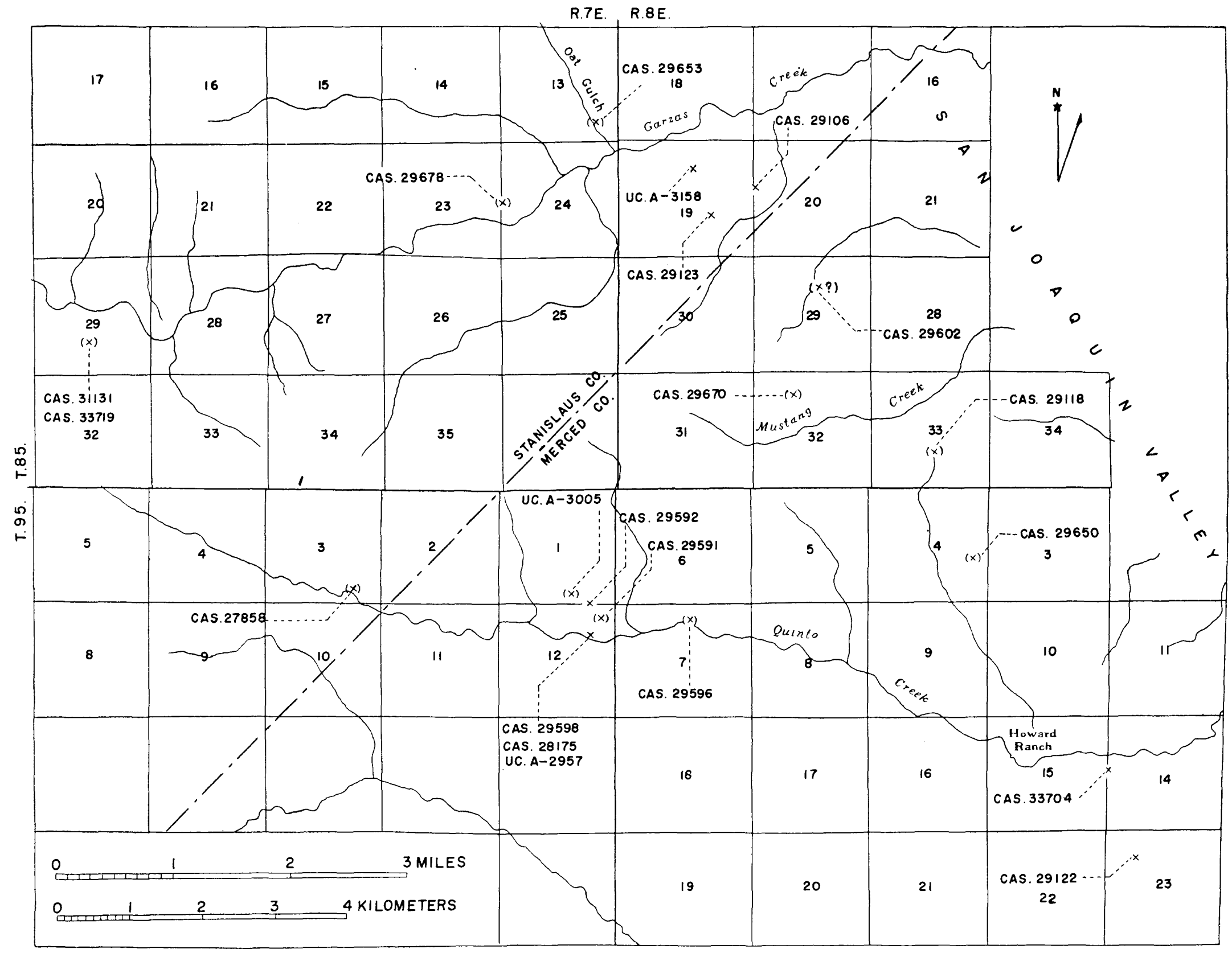

Fig. 14. Map of the Upper Cretaceous area in the northern part of Pacheco Pass Quadrangle, west side of the San Joaquin Valley, showing ammonite localities. Compiled by T. MATSUmoto from the data of UC. and CAS. 
situated on the extension of the shaly unit, but its actual stratigraphical position must be determined by further careful field work. The identified species are:

Kanabiceras septemseriatum (CRAGIN) [=Lyelliceras stanislausense ANDERSON, holotype]

Sciponoceras kossmati (ANDERSON) [= Cyrtochilus stylus ANDERSON]

Inoceramus cf. labiatus SCHLOTHEIM

The assemblage indicates the basal Turonian.

(iii) Above the shaly unit of Quinto Creek comes the third cobble-conglomerate which is followed by predominant sandstones with subordinate shale and then by greenish grey sandy shales. The last mentioned shaly unit includes the megafossil localities, CAS. 28175, CAS. 29598, and UC. A-2957, containing:

Collignoniceras cf. woollgari (MANTELL)

This suggests the middle part of the Turonian. The total thickness of the unit from the third conglomerate to the shale is about 400 meters.

(iv) Next comes the fourth cobble-conglomerate, which is followed by shales with interbedded calcareous rocks and sandstones. To this shaly unit are referred localities CAS. 29591, CAS. 29592, TM. 311, TM. 312, and probably UC. A-3005. They contain ammonites listed below, which suggest the Upper Turonian.

Subprionocyclus sp.

Scalarites sp.

Scaphites sp.

The first species is here represented by a large number of poorly preserved specimens. At locality CAS. 29585, which is located south of Pacheco Pass highway on a slope of a hill facing the valley of San Luis Gonzaga, Subprionocyclus sp. and Hyphantoceras sp. are recognized in a boulder from a conglomerate. It has not been determined whether this bed is an extension of the fourth conglomerate of Quinto Creek or otherwise. GABB (1864, p. 69) listed as a locality of his Ammonites chicoensis "Rancho de San Luis Gonzaga, Pacheco Pass, Merced County." GABB's A. chicoensis is complex and might include species of Subprionocyclus, but his specimen from this particular locality is unfortunately missing.

The fourth unit is not precisely measured in thickness, but is probably thinner than the third. It resembles lithologically the Ciervo shale of the Panoche Hills and the Yolo shale of the west Sacramento Valley.

(v) The fifth unit begins with predominant sandstones with some conglomerates, followed by mudstones. At loc. CAS. 29596, from this mudstone, ANDERson reported a large specimen of Peroniceras under a new name, $P$. quintoense ANDERSON (1958, p. 260, pl. 47, fig. 1, 1a). The unfigured inner whorl of this specimen is almost indistinguishable from

Peroniceras subtricarinatum (D'ORBIGNY)

which indicates the Coniacian in Europe.

(vi) The last mentioned locality is still about the middle of the great thickness of the Cretaceous beds in this area. The exposures along Quinto Creek are not good for the upper half. Those along Garzas and other creeks may be compli- 
mentary, but the Peroniceras-bearing shale has not been traced with certainty to other creeks, although the topography indicates its approximate positions.

Broadly speaking the upper half consists of alternating sandstones and shales or siltstones. At some horizons the former predominates over the latter, at others vice versa. The sandstones are sometimes conglomeratic. There has been no record of fossil localities for the lower part of the upper half, but SHILLING has recently discovered a Baculites from a bed (his loc. 312) stratigraphically about 840 meters above the Peroniceras locality. The specimen, which has been sent to me for identification, is :

Baculites cf. capensis Woons

From this discovery and from the stratigraphic position the lower part of the upper half is most probably Santonian.

(vii) In the middle part of the upper half of the sequence there is loc. CAS. 29678, whence came:

Baculites cf. inornatus MEEK

Inoceramus subundatus MEEK

The two species suggest the Campanian.

(viii) The upper third of the upper half was subdivided by BENNIson into Mustang shale, Quinto silt (including A, B, C; B being sandstone), Garzas sand and Volta sand members. I do not know the exact position of the boundary of the Mustang and Quinto members. Locality CAS. 29123 [= ? UC. A-3158] was assigned by ANDERSON (1958, p. 56) to the Mustang shale, but it could be in the lower part of the Quinto silt. The ammonites which I have identified from this locality are:

Pachydiscus cf. egertoni (FoRBES)

Nostoceras cf. splendidum (SHUMARD) [=Turrilites excelsus ANDERSON, holotype]

Exiteloceras (?) diabloense (ANDERSON)

Solenoceras sp.

In addition ANDERSON reported inocerami and other mollusca. The assemblage suggests the highest Campanian or Lower Maestrichtian.

The locality CAS. 28312 was assigned by ANDERSON (1958, p. 58) to the basal sandstone of the Quinto member, where he listed Baculites aff. B. occidentalis MEEK, Baculites aff. B. lomaensis ANDERson, etc. I did not see the specimens, but the specific names, if correct, would suggest the uppermost Campanian or lowest Maestrichtian.

Localities CAS. 29602 and CAS. 29653 probably fall somewhere in the siltstone of the Quinto member. From them I identify

Pachydiscus cf. subcompressus MATsumoto

Pseudophyllites (?) sp.

which suggest the Lower Maestrichtian or perhaps the uppermost Campanian.

Locality CAS. 29118 is in a pebbly, calcareous sandstone, which is probably referable to the middle of the Quinto member. It contains:

Pachydiscus (s.s.) sp. 
Glyptoxoceras (?) cf. subcompressum (FORBES) [=Diplomoceras mustangense ANDERSON, holo- and paratypes]

Baculites columna MoRTON

Baculites sp. (same as B. sp. of STEPHENson, 1941, pl. 76, figs. 5, 6)

The assemblage suggests the Lower Maestrichtian. It is recalled here again that the third species is characteristic of the top sandstone of the Panoche group in Panoche Hills.

(ix) The prolific locality CAS. 29106 [=UC. A-1905=LSJU. 3332=TM. 303] belongs to the Garzas sand. While many shells of gastropoda and pelecypoda occur abundantly at this locality, I could not find there a single piece of ammonite. Probably the environment was not favorable for cephalopoda. PAYNE (1951, pl. 2) listed "Parapachydiscus" in the column of Garzas-Volta sands, but I did not see the specimens. A locality of a mosasaur, Koloposaurus bennisoni CAMP (1942), is, however, close to this place, being assigned to the upper part of the Garzas sand.

(c) Orestimba and Carbona Quadrangles and adjacent area.-In this area, Stanislaus and San Joaquin Counties, several localities for ammonites have been found on Orestimba, Crow, Little Salado, Salado, Puerto, and Hospital Creeks and also Hetch-Hetchy Tunnel. No good geological map is at my disposal for examining the stratigraphic position of the localities. On approaching the Bay area, the geological structure seems to become complicated.

The scattered records are here sorted in the order of the geological ages suggested by the ammonites.

(i) At localities UC. A-3378, UC. B-2361, and CAS. 33705B in Hospital Canyon, not far from the edge of the San Joaquin Valley, the following ammonites occur:

Phyllopachyceras sp.

Beudanticeras huleni ANDERSON

Puzosigella sp.

Leconteites cf. lecontei (ANDERSON)

They indicate the Albian. I do not know the stratigraphic relation between these Albian and the Upper Cretaceous beds.

(ii) No Cenomanian ammonites are known in this area.

(iii) At loc. UC. B-769, on the upper course of Puerto Creek, a crushed ammonite was collected by Marshall MADDock from a unit of shale with interbedded sandstone, which is inserted "between the rocks of Franciscan complex" That ammonite is

Collignoniceras (?) sp.

suggesting the Turonian.

(iv) At loc. CAS. 27854, from a conglomerate in the upper stream valley of Orestimba Creek, on the southwest side of Wilcox Ridge, TAFF, HANNA, and Cross obtained an ammonite, which was described under a new name, Didymoceras orestimbense ANDERSON (1958, p. 197, pl. 45, fig. 4). This is absolutely identical with:

Hyphantoceras oshimai (YABE) 
That species occurs in the Upper Turonian to Lower Santonian of Japan and is closely allied to Hyphantoceras reussianum (D'ORBIGNY) from the Upper Turonian of Europe. ANDERSON assigned the conglomerate to the basal Panoche, but from the general distribution of the beds in the adjacent Pacheco Pass Quadrangle, the conglomerate is better referred to the middle part of the Panoche group. There is another locality with Hyphantoceras sp. at loc. UC. A-4976, on the same creek, southwest of Wilcox Ridge.

At loc. UC. B-776, from a gritty conglomerate in Mt. Boardman Quardrangle, Marshall MADDOCK obtained

Peroniceras (?) sp.

but I have not been supplied with precise locality data.

(v) A considerable thickness of strata between the Hyphantoceras bearing bed and another unit of relatively fossiliferous beds is barren, so far as is known. (vi) More localities have been found in the upper part of the Cretaceous sequence. I cannot tell exactly the relative stratigraphic positions of the localities in the different creeks, but there are some common species among them. The localities can be sorted into two groups-one containing ammonites of Upper Campanian aspect and the other containing those of Lower Maestrichtian aspect, but there are some which may be near the boundary. ANDERSoN (1958) referred almost all of them to the Maestrichtian Moreno, but as in the Ortigalita Peak and Pacheco Pass Quadrangles, there is no sound ground for his assignment. At localities CAS. 29664, and CAS. 29666 in the valley of Puerto Creek BENNison found the ammonites which were described by ANDERSON. My identifications differ from ANDERson's:

Pachydiscus cf. ootacodensis (STOLICZKA)

[= Parapachydiscus stanislausensis ANDERson, holotype]

Didymoceras hornbyense (WHITEAVES) [=Didymoceras californicum

ANDERSON, holotype]

Didymoceras vancouverense (GABB) $[=$ Exiteloceras bennisoni

ANDERSON, holotype; Didymoceras fresnoense ANDERSON, holotype]

At loc. CAS. 29671, on Little Salado Creek, and at loc. 34438, on Ingram Creek, BeNNISON and WILLIAMs obtained:

Pachydiscus ootacodensis (STOLICZKA)

[=Parapachydiscus sp. of ANDERSON, 1958, p. 59]

The loc. CAS.28325, on south side of Crow Creek, is the type locality of

Baculites rex ANDERSON.

At loc. CAS. 26878, on Hospital Creek, and at loc. CAS. 33722, on Crow Creek, occurred:

\section{Baculites occidentalis MEEK}

There are in the unregistered collection of LSJU. a large number of specimens of

Baculites sp. aff. B. anceps LAMARCK

that were obtained by Bostick from three localities ("N 44, N 50, and K 36") on Puerto Creek. It is associated with Metaplacenticeras pacificum SMITH at one locality. The available records of the localities are not precise enough 
to show the relative stratigraphic positions of the above mentioned three species of Baculites.

(vii) At loc. CAS. 29652, on Little Salado Creek, and at loc. CAS. 29602, on Puerto Creek, both in a shaly unit, there are examples of

Pachydiscus subcompressus Matsumoto (including Pachydiscus subcompressus obsoletus MATsUmoto)

Still more examples of the same species came from locs. LSJU. 3364 and LSJU. 3365 of the Little Salado Creek. Their matrix is a calcareous concretion in a shale. At locs. LSJU. 3362 and LSJU. 3363 of the same creek there are poorly preserved examples of

Eubaculites cf. ootacodensis (STOLICZKA)

Unfortunately none of these LSJU. numbers have any precise records of the geographical and stratigraphic positions. The two species listed above suggest the Lower Maestrichtian. Another set of ammonites which might suggest the same age is recognized in a collection from loc. CAS. 2259, Hetch-Hetchy tunnel. The species are:

Damesites cf. hetonaiensis fresnoensis (ANDERSON)

Pachydiscus (s.s.) sp.

Pachydiscus (Neodesmoceras) ? sp.

Nostoceras sp.

Baculites sp.

Finally at loc. CAS. 28399, northeast of Tracy, a deep well in the San Joaquin Valley furnished several ammonites from a shaly unit. Although ANDERson (1958, p. 57) listed their specific names, I did not examine his specimens. The only example which I saw is a crushed specimen comparable to Diplomoceras sp.

\section{Several areas, south of the Panoche Hills, west side of the San Joaquin Valley}

On the west side of the San Joaquin Valley, southward from Panoche Hills there is some structural complexity. Prominent faults (thrusts or wrench faults ?) of E-W or NWW-SEE trend appear periodically, often accompanied by folds or drag structures. Thus the Cretaceous outcrop does not extend straight to the southeast but shows a roughly zigzag outline. In addition there seem to be changes in facies and thickness. An interesting example of this situation in the New Idria Quadrangle is now being studied and will be published by Max B. PAYNE.

Ammonite localities are known in the vicinity of Coalinga, Fresno County, and also in scattered areas on the southwest side of the San Joaquin Valley. But there are no published geological maps which show clearly the stratigraphic positions of the localities. For the Cretaceous of the Coalinga area, several formational names have been orally proposed, but their definition is not clear and their usage seems to have been inconsistent among different persons. Here the locality data are sorted in local areas, so that they may be of use for further research work.

(a) Walthan Creek, west of Coalinga, Fresno County.-There are valuable 
collections in Stanford University made by Professor S. W. MULLER and his associates. Some of the specimens (with* below) have already received correct specific names by Prof. Muller but others not. Payne, Martin, and I made an excursion to look through the section along the Creek. This was of great aid in understanding the records of localities supplied by Professor MULLER (Fig. 15). A serial list of ammonites is presented here with a short explanation of the local stratigraphic sequence.

(i) At locs. LSJU. 3337 and LSJU. 3338, in a shale unit of Coalinga Hot Springs Canyon (Priest Valley Quadrangle) MULLER discovered two ammonites:

Desmoceras kossmati MATSUMoto

Puzosia sp. aff. P. subcorbarica MATsumoto

They suggest, from their occurrence in Japan, the uppermost Albian or Lower Cenomanian, but the boundary of the Lower and Upper Cretaceous cannot be fixed without the aid of more diagnostic species.

I do not know the stratigraphic sequence of the underlying rocks. Slightly above (3-6 meters) the fossiliferous parts in the shale unit MULLER found a bentonite bed, which could be of aid at least for local correlation.

(ii) Above the shaly unit comes a unit of sandstones and conglomerates, in the upper part of which MULLen obtained rudistids but no ammonites. There is a fault of NW-SE trend and on its east side appear a shaly unit and then a sandstone unit with some conglomerate, both of which run along Curry Mountain and Long Canyon (Coalinga Quadrangle). The two units along the Coalinga Hot Springs Canyon may correspond to those of the Curry Mountain, but the available evidence is not convincing. No good ammonites have been found from the units on Curry Mountain, except for a poorly preserved Desmoceras at loc. LSJU. 2960 in the shaly unit.

(iii) Another unit of bluish, greenish, dark grey shales, with subordinate interbedded sandstones, rests on the sandstones of Curry Mountain. It is probably the type of what has been called the Lower Waltham shale. It includes the ammonite localities LSJU. 2959, LSJU. 2958, LSJU. 2747 and probably also CAS. 2324. The identified species are:

Forbesiceras cf. obtectum (SHARPE)*

Acanthoceras cf. evolutum SPATH

Acanthoceras cf. sherborni SPATH

Turrilites (s.s.) cf. costatus LAMARCK

Turrilites (Euturrilites) cf. scheuchzerianus BosC

The assemblage indicates the Cenomanian. ANDERSON (1958, p. 258) reported from the same loc. CAS. 2324 "Pervinquieria aff. $P$. inflata (SowERBY)". This is rather puzzling, unless the fossils of CAS. 2324, which have dissimilar rockmatrices, prove to be mixed or to have been misidentified.

(iv) Above the shaly unit comes another unit of sandstones and conglomerates, which occupies Juniper Ridge. No ammonite has been found from this unit.

(v) Next comes another thick unit of bluish, greenish, dark grey shale with subordinate sandstone. This may be what has been called the Upper Waltham 


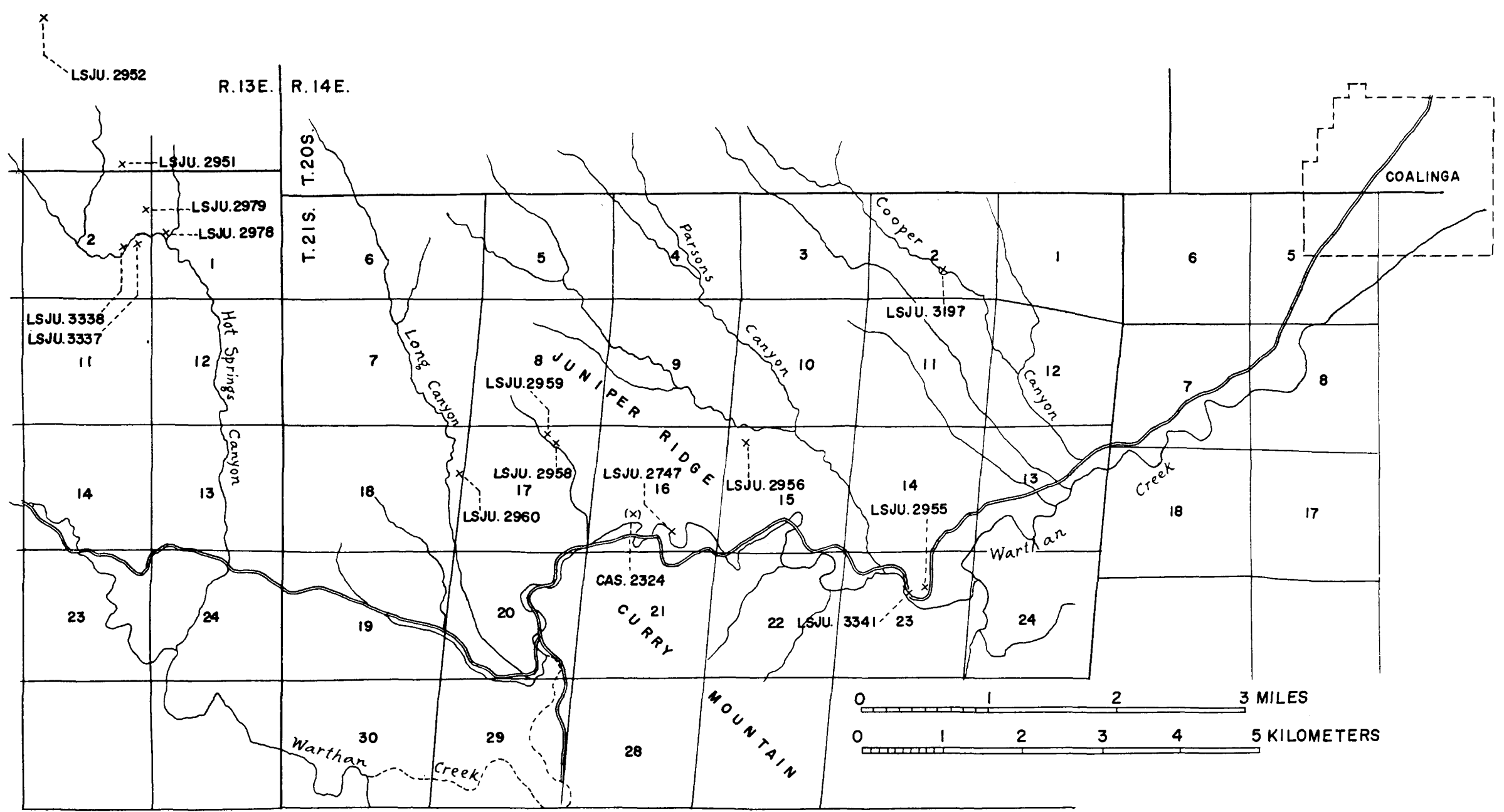

Fig. 15. Map of Warthan Creek area, Fresno County, west side of the San Joaquin Valley, showing ammonite localities. Data provided by Prof. S. W. MUlLer, Stanford University. 
shale. Its upper part includes locality LSJU. 2956, where MULLER obtained an ammonite:

Plesiovascoceras sp.

I found at loc. LSJU. 3341 [=TM. 502], from the upper part of the same unit, Inoceramus cf. labiatus Schlotheim. Thus the upper part of this shaly unit is referable to the Lower Turonian.

(vi) The shaly unit is overlain by a unit of predominant sandstones, which resembles the Ortigalita sandstone of the Panoche Hills. In the collection from loc. LSJU. 2955 I have recognized the following species:

Neophylloceras sp.

Mesopuzosia (?) sp.

Inoceramus hobetsensis NAGAO and MATSUMoTo

The last species is a guide fossil of the Turonian in Japan and is relatively abundant in its middle part. The unit of sandstone seems to run along Parsons Canyon (Coalinga Quadrangle). The superjacent part of the Cretaceous should be still very thick. Roughly speaking it occupies the Alcalde Hills, but is not exposed along Walthan creek, because of the covering by Tertiary sediments. As I did not visit the Alcalde Hills, I cannot give information of any accuracy for this part, except for a few mega-fossils to be mentioned below.

(b) Los Gatos Creek.-This creek, with its tributaries, has many localities (Fig. 16) which have supplied good ammonites. PAYNE took me there to visit some of them and to see the general geological condition. There is a kind of wrench fault running WNW-ESE approximately along the valley of Los Gatos Creek, northwest of Coalinga. There are also folds of various scales. Therefore the sequence of strata is not easily readable and the local correlation between the beds of Los Gatos and Walthan Creeks has not yet been completed. Members or lentils of predominant sandstones occur more than once, and one in the former creek seems to have been incorrectly correlated to another in the latter.

(i) In the relatively lower part there are two ammonite localities which could be of aid for correlation. One of them is LSJU. 3339 in a unit of shales that resembles those explained under (v) of Walthan Creek. It contains

Plesiovascoceras cf. californicum (ANDERSON)

which suggests the Lower Turonian. The other is LSJU. 3194 in a sandstone which is probably higher than that shaly unit, being possibly an extension of the sandstone described under (vi) of Walthan Creek. It has another Turonian ammonite:

Puzosia intermedia intermedia Kossmat

(ii) Between this sandstone and the much higher fossiliferous beds there is a great thickness of shales and sandstones that constitute the main part of the Alcalde Hills. Very few mega-fossils have been found from this thick part, except for those in and above the massive sandstone at about the midst of this part. They came from locs. LSJU. 3192 and LSJU. 3191 respectively. The former has

\section{Baculites cf. boulei ColligNoN}


which suggests the Lower Senonian. According to David Jones (oral communication) the latter had Inoceramus sp. with divergent ribs, but the specimen is now missing.

(iii) Above this poorly fossiliferous part comes a unit of predominant, finesandy siltstones, with subordinate sandstone. It is exposed along the lower course of Los Gatos Creek and extends northeastward into the Joaquin Rocks Quadrangle. It is relatively rich in ammonites, having been frequently called the "Pachydiscus silt", or sometimes regarded as an extension of the "Ragged Valley shale" of that quadrangle. I do not think the "Pachydiscus silt" is a name to be recommended, because Pachydiscus and its allied genera occur at different levels. The Japanese geologists used to give the name "Pachydiscus bed" to a part of the Cretaceous section in Hokkaido, which is mainly referable to the Santonian in terms of the international scale. Actually the members of the Pachydiscidae are distributed in several zones and Pachydiscus in the correct sense occurs at a much higher level in the Japanese sequence. Similarly in California it can be proved that Eupachydiscus (or Lewesiceras ?) occurs in the Coniacian of the Redding areas, Canadoceras, Eupachydiscus, and Anapachydiscus in the Campanian of various areas, Pachydiscus (s.s.) and P. (Neodesmoceras) in the probable Maestrichtian.

Now this silty unit has a thickness of about 245 meters and the ammonite localities do not seem to be restricted to a limited part. I had not enough time to examine the localities meter by meter, but, from my preliminary observation, at least two subzones could be distinguished within the unit. The lower one is represented by localities LSJU. 3344, LSJU. $3343 \mathrm{~B}$ and C [=TM. $509 \mathrm{~B}, \mathrm{C}$ ] LSJU. 1630, CAS. 28305, LSJU. 3342 [=TM. 505], SOC. K-82, and probably LSJU. 1628. The species from them, which I identified, are as follows:

Anapachydiscus sp. (relatively less inflated form)

Tetragonites popetensis $\mathrm{YABE}$

Baculites inornatus MEEK

Baculites occidentalis MEEK

Inoceramus subundatus MEEK

B. occidentalis MEEK is characteristic of this part. This species has frequently been misidentified as $B$. chicoensis TrAsk, but I have seen no example of the latter species from this unit of the Coalinga area. The above assemblage indicates the Campanian, most probably the Upper Campanian.

The localities which would fall in the upper subzone are LSJU. 3345 [=TM. 507], LSJU. 1629, and probably also CAS. 2368, CAS. 2366, and CAS. 2362 [ $\doteqdot$ CAS. 463]. The identified species are as follows:

Damesites hetonaiensis fresnoensis (ANDERSON)

[=Neokotoceras fresnoense ANDERSON]

Hauericeras cf. rembda (FoRBES)

Pachydiscus cf. egertoni (FORBES) [=Parapachydiscus coalingensis

ANDERSON, holotype]

Pachydiscus (Neodesmoceras) (?) sp. aff. P. (N.) catarinae (ANDERSON 


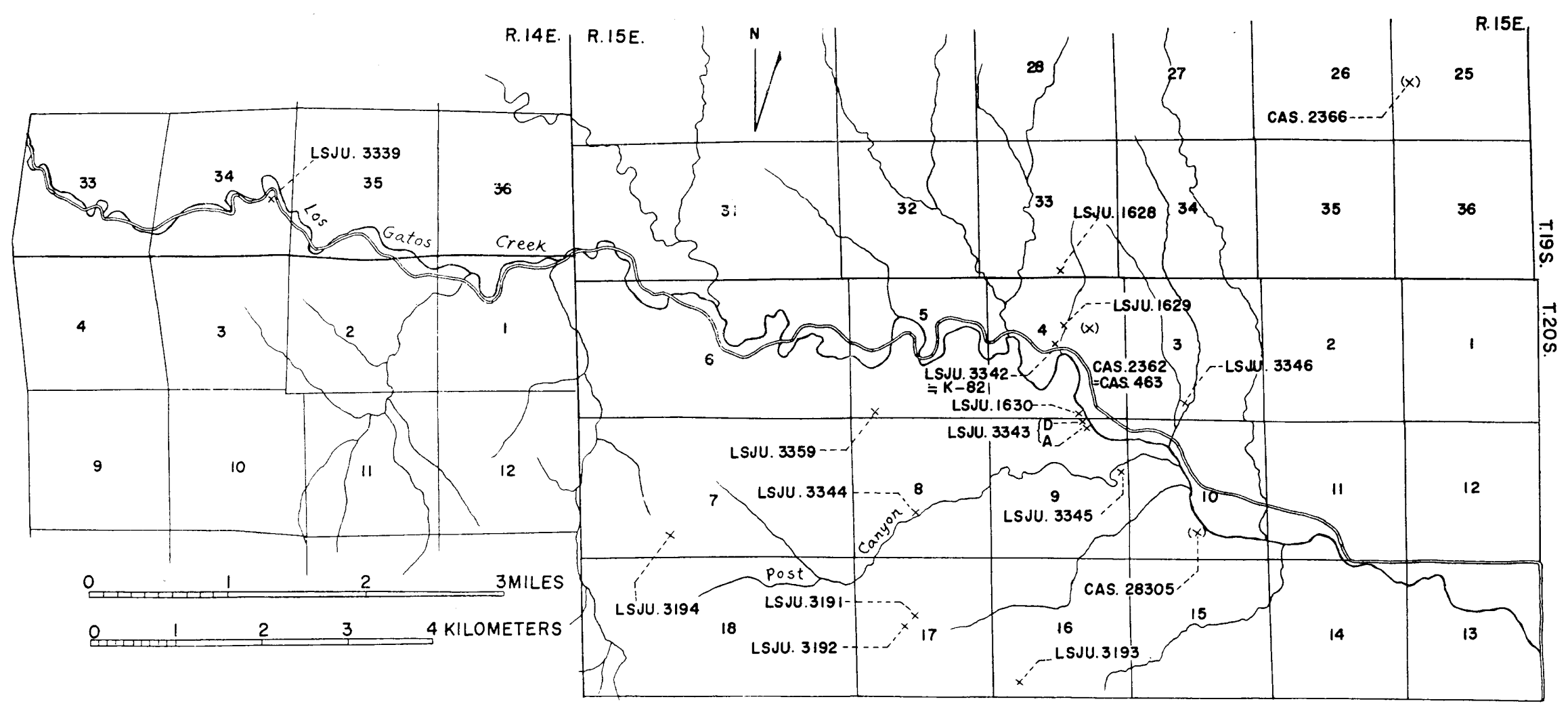

Fig. 16. Map of Los Gatos Creek area, northwest of Coalinga, Fresno County, west side of the San Joaquin Valley, showing ammonite localities. Data provided from various sources, including Prof. S. W. MULLER's information. 
and HANNA) [a transitional form from Anapachydiscus californicus (YABE) ]

Pachydiscus cf. ootacodensis (STOLICZKA)

Anagaudryceras. cf. mikobokense CoLLIGNON

Gaudryceras (Vertebrites) kayei (FoRBES)

[=Lytoceras (Gaudryceras) coalingense ANDERSON, holotype]

Tetragonites popetensis $\mathrm{YABE}$

Nostoceras (?) sp.

Baculites lomaensis ANDERSON

Baculites rex ANDERSON

Inoceramus sp. aff. I. shikotaensis NAGAO and MATSUMOTO

From the regional comparison of the faunal elements with those of British Columbia, Japan, southern India, and Madagascar, the age of the faunule is referable to the Lower Maestrichtian or the uppermost Campanian. But subzonal separation of the species of Baculites in this and other areas in California must be examined by further careful collecting.

There is one more locality under the same number of CAS. 2362, which contains :
Pachydiscus cf. ootacodensis (STOLICZKA)
Didymoceras hornbyense (WHITEAVES)
Didymoceras vancouverense (GABB)
Baculites occidentalis MEEK
Inoceramus cf. subundatus MEEK

Locality LSJU. 3359 has Baculites rex ANDERSON, but its stratigraphic position was judged by MULLER to be relatively lower. Another locality, LSJU. 3353, is too broadly recorded, but is presumed to be referable to somewhere in this silty unit. It has furnished a large ammonite:

Anapachydiscus cf. californicus (YABE)

(iv) Above the silty unit comes a unit of calcareous sandstone which is sometimes called "Brown Mountain sandstone". It contains some molluscan shells. I have obtained only fragmentary remains of Baculites at locality LSJU. 3346 [=TM. 506]. It is :

Baculites cf. rex ANDERSON

(v) A narrow belt of shales can be traced between the "Brown Mountain sandstone" and the unconformably overlying Tertiary sediments. This is comparable with the Moreno shale, because of its lithological similarity and because of the existence of Siphogenerinoides whitei, a guide foraminifera of the Marca shale. To this unit belong the locality CAS. 900 and CAS. 1790. The ammonites occur rather sparsely.

Tetragonites (Saghalinites) (?) sp.

Diplomoceras (?) sp.

Baculites rex ANDERSON

(c) Southern area of Joaquin Rocks Quadrangle.-The available ammonite localities in this area are mostly concentrated in the silty unit which extends 
northward from Los Gatos Creek. The unit is called the Ragged Valley shale, and is followed below by a thick unit of heavy bedded concretionary sandstones with subordinate shales, called the Joaquin Ridge formation. The locality data are not precise enough to rearrange them into finer stratigraphical order, but there are species common to the different localities. The index map (Text-fig. 17) shows only the approximate positions of the localities: SOC. K-86, SOC. K-85, LSJU. 1631, CAS. 2361 [= CAS. 31593], CAS. 28304, and CAS. 28303. Localities 103 and 104 of F. R. KELleY (1958, personal communication through H. G. ScHENCK) are also included here. The ammonites which I have identified are as follows:

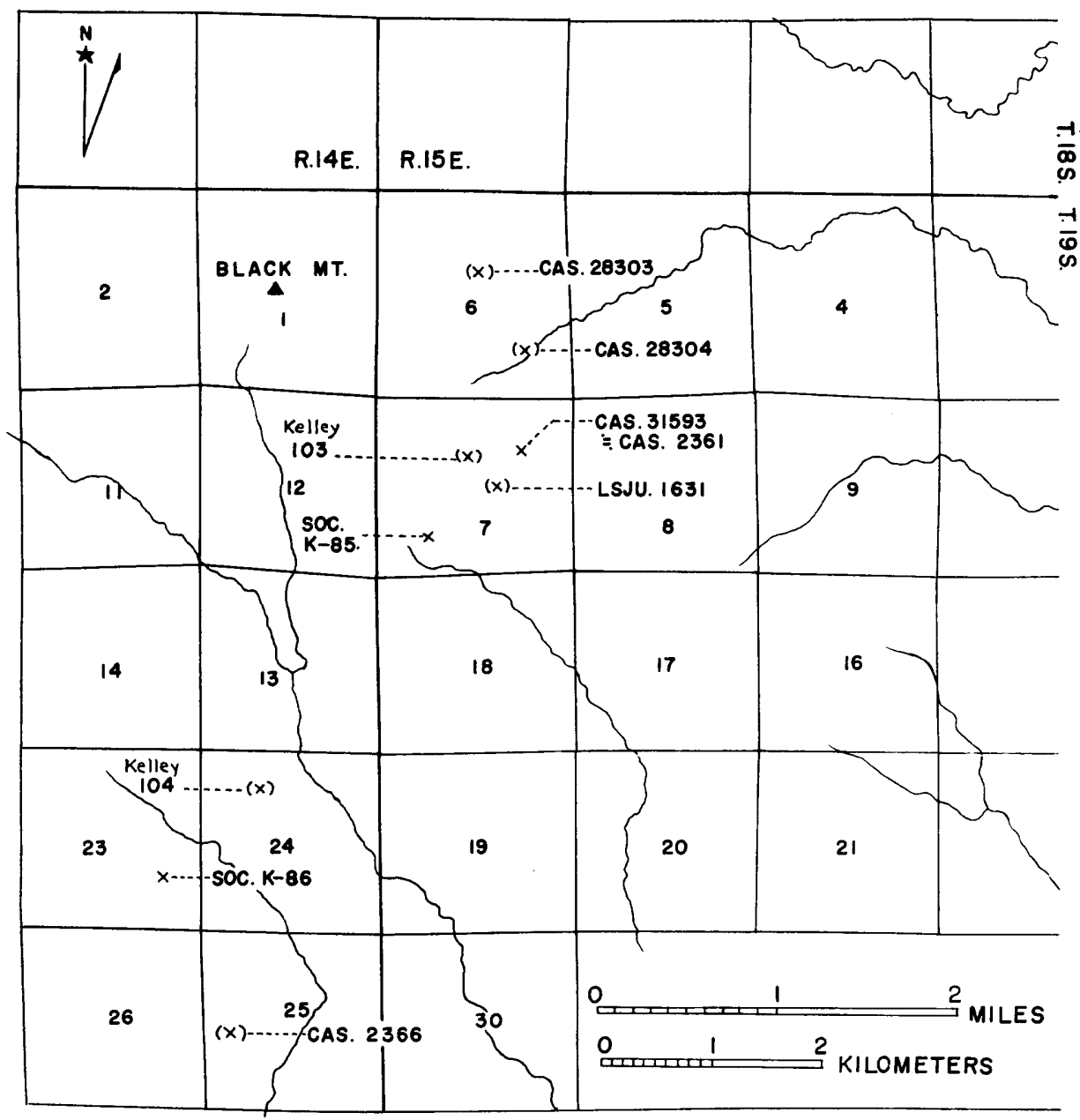

Fig. 17. Map of the southeastern flank of Joaquin Ridge, Fresno County, west side of the San Joaquin Valley, showing ammonite localities. $(x)$ : approximate location. Compiled by T. MATSUmoto from the data of LSJU., CAS., M. V. KIRK and F. R. KELLEY. 


\author{
Desmophyllites cf. diphylloides (FoRBES) \\ Damesites hetonaiensis fresnoensis (ANDERSON) \\ Hauericeras rembda (FORBES) [= Hauericeras churchi ANDERSON, \\ including holotype] \\ Pachydiscus ef. subcompressus obsoletus MATsumoto \\ [=Joaquinites fascicostatus ANDERSON, including holotype] \\ Pachydiscus cf. neevesi WhiteAves \\ Anagaudryceras sp. \\ Gaudryceras (Vertebrites) cf. kayei (FoRBES) \\ [=Lytoceras (Gaudryceras) birkhauseri ANDERSON, holotype] \\ Didymoceras (Nostoceras ?) vancouverense (GABB) \\ Solenoceras sp. \\ Baculites lomaensis ANDERSON \\ Baculites rex ANDERSON
}

The type locality of Baculites lomaensis ANDERson is CAS. 2361, and specimens occur abundantly at this and other localities of the silty unit. The assemblage of the species is closely similar to that of the "upper subzone" in the silty unit of Los Gatos Creek, suggesting the uppermost Campanian or Lower Maestrichtian. The equivalent of the "Iower subzone" has not been confirmed in Joaquin Rocks Quadrangle, so a possibility of its extension in the higher part of Joaquin Ridge sandstone should be examined. In this connection there is an interesting but questionable record of ammonites. That is the locality LSJU. 3347, without precise information, but for the note "Black Mountain, California, a float boulder 1/8 mile of HoFFMASTER's Mountain house." The rock matrix is greenish, calcareous sandstone (concretion ?) and the contained ammonites are:

Pseudokossmaticeras cf. tchihatcheffi (BöнM)

Baculites rex ANDERSON

They were collected by H. HANNIBAL and A. W. AMBrose. There are a number of "Black Mountains" in California. Some of them are in the area of Franciscan complex, but one of them is just in the area of the Joaquin Ridge sandstone of the Joaquin Rocks Quadrangle. Since the rock matrix shows no sign of intense tectonic deformation, the possibility of the derivation from the Franciscan complex can be rejected. I merely mention here this interesting record, leaving the field examination for a future work. The ammonites suggest the uppermost Campanian or Lower Maestrichtian. This is also the first record of the discovery in the northern Pacific area of Pseudokossmaticeras, a genus known in southern India, Asia Minor, and southern Europe.

One locality, CAS. 462, is recorded in the area of the Moreno shale. It contains a poorly preserved specimen of

Eubaculites (?) sp.

According to M. B. PAYNE (oral communication, Dec. 1957), the Cretaceous rocks extend from the Joaquin Rocks Quadrangle westward to New Idria Quadrangle, showing a significant decrease of the thickness of the Panoche group. There is, however, very little control of correlation by mega-fossils. I 
cannot give here any positive evidence from my study of ammonites, but, so far as the southern part of Joaquin Rock Quadrangle is concerned, there is no significant time gap at any boundary of the units from the Ragged Valley shale, through Brown Mountain sandstone, to Moreno shale, since Eubaculites and Baculites rex range from the uppermost Campanian to the Maestrichtian.

(d) Reef Ridge and adjacent area.-This is located in the northern part of Cholame Quadrangle (scale 1:125000), next south of Coalinga Quadrangle. Here the outcropping Cretaceous area is narrower than in the Coalinga district, owing to extensive development of Tertiary strata. STEWART (1946) referred the Cretaceous beds in this area to the Panoche formation. The ammonites at my disposal came from three localities (Text-fig. 18). Two of them, UC. A-7581 and UC. A-4890, are southwest of Reef Ridge. The former is recorded to come from the limy concretions of a shale, 60 meters below the contact with the Tertiary McClure shale. It contains:

Neophylloceras ramosum (MEEK)

Baculites cf. inornatus MEEK

The latter is at 30 meters stratigraphically below the base of the McLure shale. It has a considerable number of specimens of:

\section{Baculites rex ANDERSON}

The former suggests the Upper Campanian, and the latter the uppermost Campanian or Maestrichtian. The third locality is somewhat doubtful because there are two labels on one specimen. One of the labels indicates "Coalinga", without

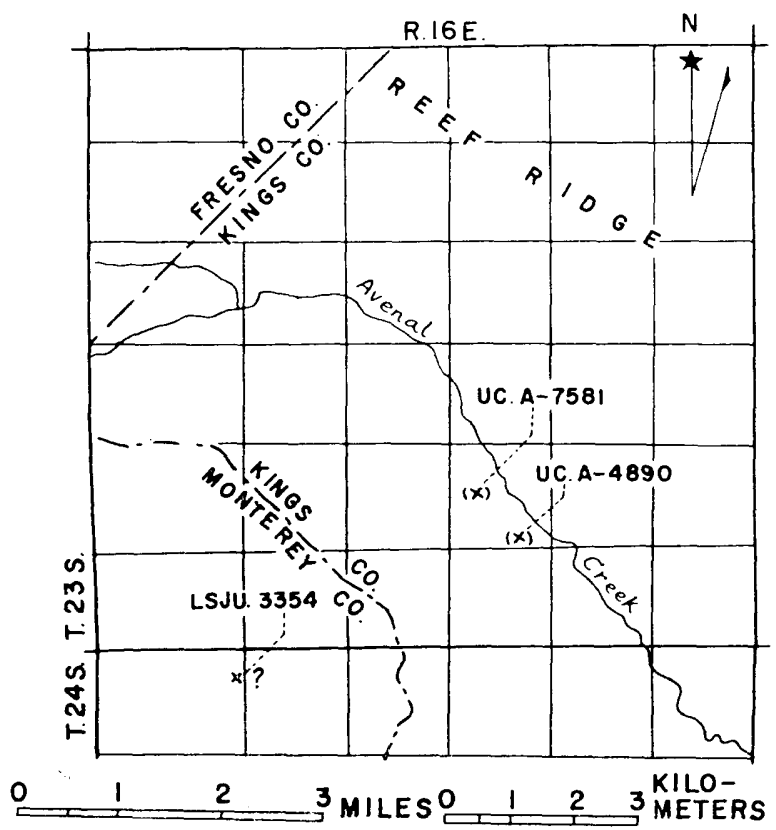

Fig. 18. Map of the Reef Ridge, Cholame Quadrangle, southwest side of the San Joaquin Valley, showing ammonite localities. Data provided from UC. 
showing precise location; the other shows a precise locality which falls in the center of the northern half of Cholame Quadrangle $(1: 125000)$, further southwest from the above two localities beyond the boundary of Kern and Monterey Counties. The specimen itself is identified as

$$
\text { Anapachydiscus cf. arrialoorensis (STOLICZKA) }
$$

suggesting the Campanian. There is no record of local stratigraphy about this locality.

(e) Temblor Range and Shale Hills, Kern County.-Another set of ammonites has been furnished from several localities scattered in Temblor Range and Shale Hills, which occupy the southeastern part of Cholame Quadrangle (scale 1: 125000), southwestern part of Lost Hills Quadrangle $(1: 125000)$, and northwestern portion of McKittrick Quadrangle (1:125000) [ $\doteqdot$ Simmler Quadrangle (scale 1:62500) ]. They are CAS. 1552, CAS. 31401, LSJU. 3358, CAS. 31402, and UC. A-4959. Their locations are indicated on a map (Text-fig. 19) as far as possible. The fossils came from concretions in a shale unit, outcropping on the low hills. The identified species are:

Desmophyllites diphylloides (FORBES) [=D. siskiyouensis ANDERSON]

Tetragonites popetensis $\mathrm{YABE}[=$ Lytoceras (Tetragonites) kernense ANDERSON, including holo- and paratypes]

Baculites rex ANDERSON

The last species was misidentified by ANDERson as $B$. inornatus MeEk and $B$. chicoensis TrASK, and he assigned locality CAS. 1552 to the Coniacian. From the above listed assemblage the fossiliferous shale is correlated with the "Ragged Valley shale" of Los Gatos Creek and Joaquin Rocks Quadrangle, being referable to the Upper Campanian or Lower Maestrichtian.

In addition to the above, there are three localities, CAS. 31368, CAS. 31366, and CAS. 33702, along Cedar Canyon. Their records are not precise enough to be plotted on the map. They have furnished the following ammonites:

Bostrychoceras sp.

Nostoceras sp.

Baculites cf. occidentalis MEEK

The specimens are, however, poorly preserved and their stratigraphic position relative to the other set of ammonites is not well known.

\section{Santa Ana Mountains, Orange County, southern California}

(By Tatsuro Matsumoto and W. P. Popenoe)

Through the papers of PACKARD (1916a, b, 1921, 1922), WARING (1917), and Popenoe $(1937,1942,1957)$, the Cretaceous of the Santa Ana Mountains, Simi Hills, and Santa Monica Mountains, southern California is well known for its rich molluscan faunas. The pelecypoda and gastropoda are predominant over cephalopoda, but some ammonites occur associated with other mollusca.

Stratigraphically the Santa Ana Mountains are best studied among them. For the ammonites of this area MATSUMOTo depends much on the collections at UCLA. and CIT. of POPENOE and his associates. Some of the collections in 


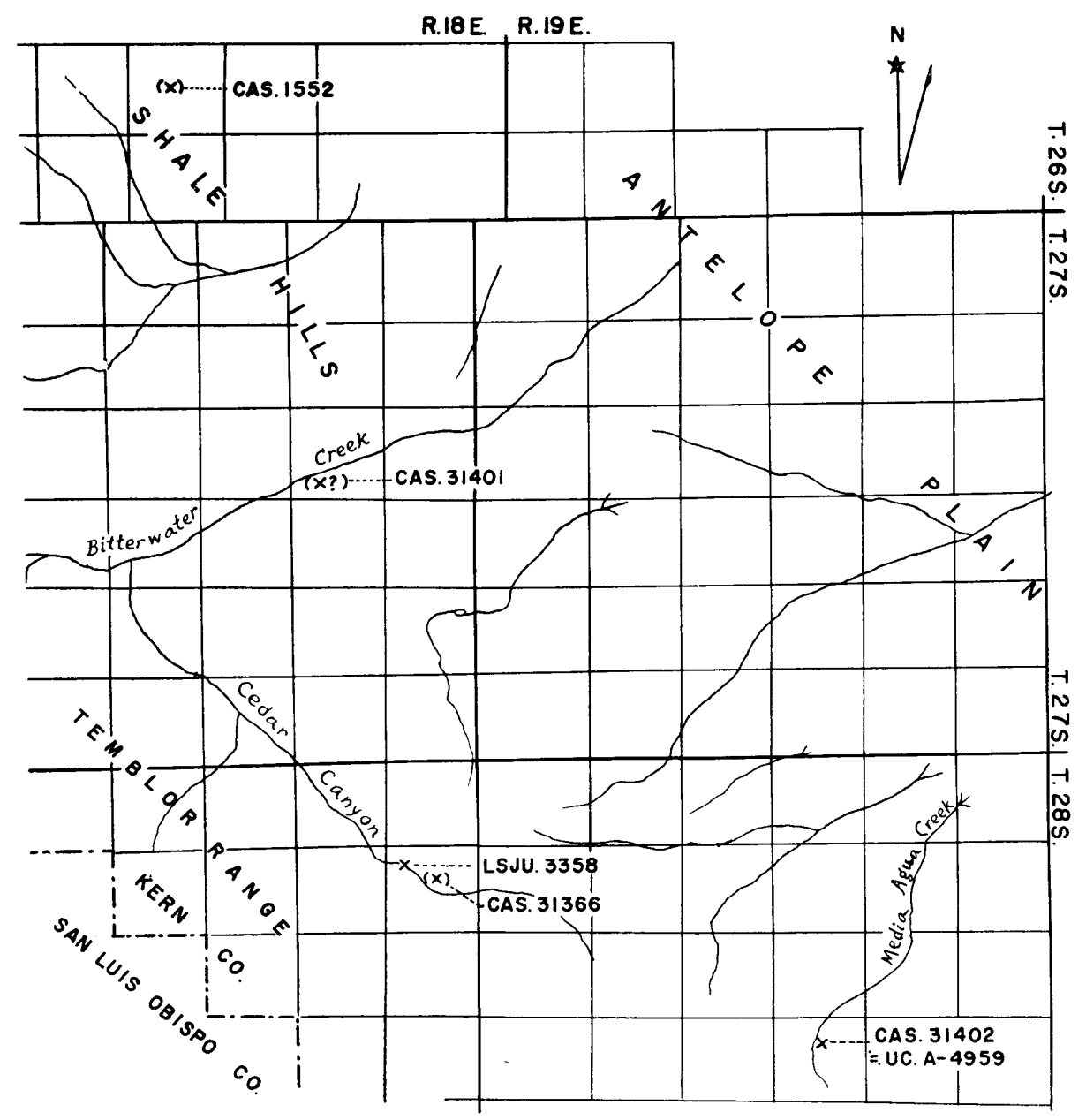

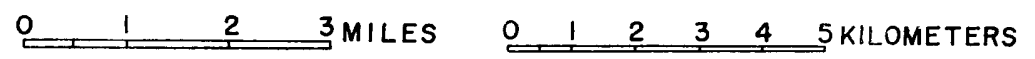

Fig. 19. Map of the Temblor Range-Shale Hills, Kern County, southwestern side of the San Joaquin Valley, showing ammonite localities. Data provided from CAS., LSJU., and UC.

other institutions were also available.

Following the stratigraphic sequence established by POPENOE (1937, 1942), ammonite localities are briefly explained in ascending order.

I. Trabuco formation.-Red conglomerates and sandstones, over 90 meters thick. It rests on the Triassic meta-sediments and Jurassic (?) volcanics with a profound unconformity. Unfossiliferous, so far as is known.

II + III. Ladd formation.-Consisting of the two members:

II. Baker Canyon conglomerate.-Boulder conglomerates grading upward into sandstones, 60-90 meters thick. The sandstones in the upper part and the 
transitional part from the Baker Canyon member to the Holz shale are highly fossiliferous. To the calcareous sandstones in the upper part belong the ammonite-bearing localities CIT. 979, CIT. 978, CIT. 1062, CIT. 1068, CIT. 1069, and probably UC. 2195 and also one of CAS. 252. The identified ammonoid species are as follows:

Subprionocyclus neptuni (GEINITZ)

Scaphites cf. gillisi ANDERSON

Sciponoceras sp. aff. S. bohemicum (FRITSCH)

They indicate the .Upper Turonian. There is a possibility that the boundary of the rock-stratigraphic units, Baker Canyon sandstone and Holz shale, slightly shifts in age from place to place. Locality UCLA. 3781 is recorded to be in a sandstone, but has poorly preserved specimens of Subprionocyclus sp., which is rather comparable with $S$. normalis (ANDERSON). At loc. CIT. 79, which is situated at the Baker Canyon-Holz transition, Subprionocyclus occurs fairly commonly, but the specimens are more or less secondarily deformed. They show some characters which are intermediate between $S$. neptuni (GEINITZ) and $S$. normalis (ANDERSON). Among the associated species there are Sciponoceras sp. aff. S. bohemicum (FRITSCH) and Hyphantoceras sp. aff. H. venustum (YABE).

III. Holz shale.-Sandy shales, with interbedded sandstones and lenticular conglomerates, 300-460 meters thick. Its lowest part has some ammonites, being represented by locs. CIT. 99 and probably UC. 2142. The species are:

Subprionocyclus cf. normalis (ANDERSON)

Baculites (?) sp.

This part is probably the uppermost Turonian.

Locality LSJU. 3350 is the only locality that is referable to the main part of the Holz shale, although its position in a measured section is not precisely known. I have recognized in the collection there a species of Baculites:

Baculites boulei CollignoN

This species occurs in Members IV and $\mathrm{V}$ of the Redding formation, being more common in the lower part of Member V. It indicates the Lower Senonian.

The fine sandstones in the upper part of the Holz shale are fossiliferous, being called the Turritella chicoensis and the $T$. chicoensis perrini beds. The ammonite-bearing localities CIT. 1053 and CIT. 83 belong to these beds respectively. They have furnished:

Canadoceras cf. multisulcatum (WHITEAVES)

Pseudoxybeloceras (?) lineatum (GABB)

They indicate the Campanian. C. multisulcatum is very close to, and possibly identical with, C. yokoyamai (JIMBO), the latter of which occurs in the lower part of the upper half of the Chico Creek section and also in the Mill Creek locality, suggesting the relatively lower part of the Campanian. Pseudoxybeloceras (?) lineatum (GABB) is long ranged, beginning to appear in the same part of the Chico section.

All the above records of ammonites confirm the conclusion of PECK, IMLAY, 
and POPENOE (1956) that the Holz shale ranges in age from uppermost Turonian to Lower Campanian.

IV + V. Williams formation.-Consisting of the two members:

IV. Schulz conglomerate.-Boulder conglomerates and coarse sandstones, about 60 meters in average thickness. There is no ammonite-bearing locality which can be assigned to this unit with certainty. PoPenoe (1942, p. 174) has already mentioned that the Schulz member is essentially unfossiliferous, except for the reworked material.

V. Pleasants sandstone.-Shaly sandstones with intercalated. beds of fossiliferous, calcareous sandstones, about 90 meters in average thickness. It includes localities CIT. 974, CIT. 975, CIT. 976, LSJU. 3349, and LSJU. 3351. The ammonites from them are:

Anapachydiscus cf. deccanensis (STOLICZKA)

Metaplacenticeras pacificum (SMITH)

Baculites sp. cf. rectus MARshaLl or bailyi Woods

The second species is so diagnostic of this unit that POPENOE (1942) called the faunal division "Metaplacenticeras pacificum division". The same species occurs also in the Hornbrook, Enos Cànyon, and Bay areas in the relatively higher part of the sections. The allied species Metaplacenticeras subtilistriatum (JIMBO) occurs in the upper part of the Campanian in Japan. Anapachydiscus deccanensis (STOLICZKA) is long ranging, and its occurrence in the lower-middle part of the Campanian in Madagascar may not be strictly applied to the Californian section. Taking also the relative stratigraphic position of the Pleasants sandstone into consideration, this member is best referable to the upper part of the Campanian.

At loc. UCLA. 2415, in EI Toro Quadrangle, Mrs. L. E. SAUL collected the following interesting assemblage:

Anapachydiscus cf. arrialoorensis (STOLICZKA) or peninsularis (ANDERson and HaNNa)

Metaplacenticeras cf. pacificum (SMITH)

Pseudophyllites sp.

Baculites cf. rex ANDERSON

Eutrephoceras sp.

The assemblage suggests a somewhat higher part than the undoubted Pleasants sandstone member. POPENOE has clarified that the sandstone at this locality is in an elevated fault block bounded on all sides by the Miocene, and its molluscan faunule, other than cephalopoda, also suggests a slightly later age than the prolific part of the Metaplacenticeras pacificum division.

There are still more ammonite localities, but I cannot record here precisely their stratigraphic positions. The localities UC. 2166, UC. 2135, and UC. 2151 were mentioned by PACKARD (1916, p. 145) as belonging to the faunal zone characterized by "Turritella pescaderoensis". The first locality represents, according to him, deeper-water facies than the other two. T. pescaderoensis has been transferred to Turritella chicoensis GABB, which, in turn, is subdivided into 
a dwarf form, occurring in the middle and upper but not uppermost part of the Holz shale, a giant, round-whorled form, characteristic of the uppermost part of the Holz shale, and a giant, flat-worled form, occasionally found in the Williams formation (POPENOE, 1937, p. 400). We do not know to which of the three fossiliferous parts should be referred PACKARD's localities. Loc. UC. 2166 is the type locality of

Anapachydiscus californicus (YABE)

and from the other two came

Baculites cf. inornatus MEEK.

From the paleontological standpoint, Anapachydiscus californicus (YABE) is just transitional from $A$. fascicostatus (YABE) to Pachydiscus (Neodesmoceras) catarinae (ANDERSON and HANNA). Therefore the Campanian, probably the relatively upper part of the Campanian, is suggested from this ammonite. Baculites inornatus MEEK is favorable for this suggestion.

From the arkosic sandstone at loc. CIT. 85 ANDERSON (1958) reported Bostrychoceras trabucoense ANDERSON and Bostrychoceras sanctaeanae ANDERSON. The former is too fragmentary to be compared exactly with Bostrychoceras otsukai (YABE), but the latter is very close to an undescribed, crassicostate species which is common in the Upper Campanian Inoceramus schmidti zone of Japan. From loc. CAS 252a came

Pachydiscus buckhami UsHeR

and from loc. CIT. 96

Pachydiscus cf. neevesi WhItEAvEs

both of which suggest the Campanian, as Baculites cf. inornatus MeEK from loc. UC. A-3404 (Lucas Canyon).

Finally, from the evidence of ammonites, the unconformity at the base of the Williams formation does not seem to represent a great time gap.

\section{Other areas in southern California}

The ammonite localities are much more scattered in other Cretaceous areas of southern California as compared with those in the Santa Ana Mountains. The ammonites are of the higher stages of the Upper Cretaceous.

(a) Santa Monica Mountains, Los Angeles County.-The stratigraphic succession established by H. D. B. WILsON (in POPENOE, 1942) east of Topanga Canyon is cited here.

Underlying: Santa Monica slate

\section{Unconformity}

I. Red conglomerates, similar to Trabuco conglomerate, 230 meters (maximum)

II. Thick-bedded arkose, 760 meters; resting unconformably on Member I

III. Cobble-conglomerates, 1070-1220 meters

IV. Fine-grained, massive or well bedded, sandstones, 90 meters $(+)$

V. Arkose, 300 meters in the exposed part 
Overlying: Tertiary beds, overlapping

The fourth member is fossiliferous, including loc. CIT. 54, where occurs: Metaplacenticeras pacificum (SMITH)

WARING (1917) described from his "loc. 3", M. pacificum (SMITH), M. sanctaemonicae (WARING), and $M$. californicum (ANDERSON). However, these might all represent one variable species, $M$. pacificum (SMITH) (1900), to which $M$. subtilistriatum (ЈIмBo) (1894) is closely allied. PoPenOE (1954, p. 17) listed "coarse-ribbed giants of Pachydiscus", which, in my preliminary observation, belong to Eupachydiscus n. sp. (?) allied to E. lamberti CoLlignon, from the Campanian of Madagascar. POPENOE's correlation of Member IV with Pleasants sandstone is reasonable. A Campanian age is also indicated by Inoceramus subundatus MEEK [=I. whitneyi GABB in WARING, 1917, p. 62, pl. 8, fig. 9]. Inoceramus pembertoni WARING from his "loc. 3" is a specialized form of the group of I. balticus BöHM, to which group I. subundatus MEEK also belongs.

Among the undescribed specimens of the collection of Stanford University from loc. LSJU. 3352 ("Los Rosas ?, Santa Monica Mts.") there is an ammonite:

Pachydiscus (s.s.) cf. subcompressus Matsumoto

which suggests Upper Campanian or Lower Maestrichtian. Its matrix is a black, silty, calcareous nodule, and does not seem to fit to any of the five members of WILSON.

(b) Simi Hills, Ventura County.-PoPENoE (1942, 1954) cited Kew's (1924) succession for the Cretaceous beds of this area, dividing them into two:

Lower member: calcareous sandstone and then shale above, 150 meters

Upper member: thick sandstones with interbedded shales, 1670 meters He noted that the lower member is much thicker and more complex than KEW's. The calcareous sandstone in the lower part is fossiliferous, including the localities CIT. 1159 [=CAS. 699] and CIT. 1537. Among many mollusks I have recognized:

Metaplacenticeras pacificum (SмrTH)

Baculites cf. inornatus MEEK

Inoceramus cf. subundatus MEEK

According to POPENOE (personal communication) the first species occurs abundantly there. From locality LSJU. 2554 (Dayton Canyon) the following species are identified:

Anapachydiscus cf. arrialoorensis (STOLICZKA)

Metaplacenticeras sp.

Baculites cf. inornatus MEEK

The Metaplacenticeras bearing beds in Simi Hills are probably correlated in age with the Pleasants sandstone of the Santa Ana Mountains, as Popenoe (1942, 1954) concluded from his study of the molluscan faunas. There is no reliable evidence for ANDERSON's (1958, p. 33-44; p. 75) assignment of the Metaplacenticeras-bearing beds to the Coniacian.

In the upper member, slightly below the base of the unconformably overlapping Tertiary, POPENOE (1954, p. 17) indicated the occurrence of an ammonite: 
Pachydiscus (Neodesmoceras) catarinae (ANDERSON and HANNA)

This species occurs commonly at several localities in the Rosario formation of Baja California (ANDERSON and HANNA, 1935; also many other subsequent collections). It is associated there with a new species (or subspecies ?) which is related to Baculites occidentalis MEEK but is closer to Eubaculites, and Inoceramus shikotanensis NAGAo and MATSUmoto [=Inoceramus pacificum ANDERSon and Hanna, 1935, non Woods, 1917]. The last species and Pachydiscus (Neodesmoceras) japonicus MAтsumoто are characteristic of the Lower Maestrichtian of Japan. Neodesmoceras is known also in the Maestrichtian of Madagascar (ColligNoN, 1952, 1955a).

From the evidence of ammonites, therefore, I conclude that the outcropping Cretaceous beds of Simi Hills range from the Upper Campanian possibly to the Lower Maestrichtian.

(c) Wheeler Gorge, eastern Santa Ynez Mountains, Ventura County.-A generalized columnar section of the Cretaceous beds at Wheeler Gorge was figured by POPENOE (1954, fig. 2B). About 1500 meters of hard shales with some conglomerates are shown. S. W. MULLER collected at loc. LSJU. 3348, north of Wheeler's Hot Springs, a large, deformed specimen of Pachydiscus (s.l.) sp., which is possibly comparable with P. (Neodesmoceras) or a smoothish outer whorl of Pachydiscus (s.s.). It is associated with Inoceramus sp. related to I. shikotanensis NAGAo and Matsumoto.

(d) Southwestern part of Santa Barbara County.- There is one published record for the ammonite locality of this area. It is from the Debris Dam sandstone of PAGE, MARKs, and WALKER (1951), being represented by large specimens of Baculites from loc. LSJU. 2794 and LSJU. 2795. The species is Baculites rex ANDERSON

suggesting the Uppermost Campanian or Maestrichtian.

Among the unpublished records, POPENOE has shown me a deformed ammonite from loc. CIT. 623, near Pt. Conception. It is referable to Menuites sp.

(e) Point Loma and La Jolla, San Diego County.-The outcrops of the Cretaceous beds are very narrow in this area, as reported by HANNA (1926) and GRANT and Hertlein (1944). The specimens of ammonites from Point Loma (locs. CAS. 1173 and CAS. 13289) are:

Menuites cf. menu (FoRBES)

Baculites cf. lomaensis (ANDERSON)

They suggests again an age close to the Campanian-Maestrichtian boundary. PopenoE's (1954, p. 20) remarks on the age of Point Loma Cretaceous faunule are acceptable. I have not seen the specimen of Baculites which is said to have come from La Jolla.

\section{San Francisco Bay Area}

There is a considerable number of ammonite localities in the San Francisco Bay area. Some of them are classical, dating back to GABB (1864) and WHITE 
(1889). But the Cretaceous stratigraphy of the area has not yet been clarified, because of the highly complicated geologic structure and discontinuous outcrops. The situation is well shown in the published geological maps, such as those by WEAVER (1949) for the area north of San Francisco and by HUEY (1948) for the Tesla Quadrangle, Alameda County. Even in the area of the Franciscan group Cretaceous ammonites have recently been discovered (SCHLOCKER, BoNILLA, and ImLAY, 1954; Hertlein, 1956), but the stratigraphic information of the localities is very poor.

Be that as it may, ammonites offer very good control for age determination and will give clues for interpreting reasonably the complicated geologic structure. From the evidence of ammonites almost all the stages from Albian to Maestrichtian are proved to exist in the area, but the localities are too scattered to be compiled into a generalized stratigraphic sequence.

(i) Localities of ammonites suggesting the Albian.-HUEY (1948) mentioned the occurrence of some Lower Cretaceous ammonites from the Tesla Quadrangle, but the specimens were not at my disposal. I agree with SCHLOCKER et al. (1954) in the generic identification of Douvilleiceras for an ammonite from the northwestern part of San Francisco bordering the South Bay of the Golden Gate Channel.

(ii) Localities of ammonites suggesting the Cenomanian.-I also agree with IMLAY and HERTLEIN (in HERTLEIN, 1956) in the identification of Mantelliceras for another ammonite from north of Bird Rock (Needles), just north of the north end of Golden Gate Bridge. Alcatraz island at the eastern end of Golden Gate is the type locality of Inoceramus elliotii GABB, 1869. One of the syntypes (=figured specimen of StEwarT, 1930, p. 106, pl. 2, fig. 2), which I saw at the Academy of Natural Sciences of Philadelphia, resembles Inoceramus crippsi MANTELL, a Cenomanian species.

In Contra Costa County, a fragmentary specimen from loc. UC. A-3823 has recently been described under the name Acanthoceras lecontei ANDERson (1958, p. 242, pl. 13, fig. 1, 1a). This is probably better referable to Mantelliceras than to Acanthoceras, suggesting the Lower Cenomanian. Close to this locality Puzosia weaveri ANDERson (1938, p. 189, pl. 42, fig. 4) was reported. It was tranșferred to Puzosia (Holcodiscoides) by ANDERSON (1958, p. 240) but is more likely referable to Puzosia (s.s.), being unrelated to Holcodiscoides of the Marshallitinae.

At loc. CAS. 33729, in the Berkeley Hills, there is a Cenomanian species referable to:

Turrilites costatus LAMARCK

In Curry Creek (or Curry Canada) in the Mount Diablo area, there are two members of acanthoceratids. One of them is:

Acanthoceras whitei Matsumoto [=Ammonites turneri White, 1889, non SOWERBY, 1825]

The other, from loc. CAS. 28104 [=CAS. 25627], is :

Calycoceras cf. orientale Matsumoto, SAIto, and FukADA [=Calycoceras 


\section{(Eucalycoceras) diabloense ANDERSON]}

suggesting the Middle to Upper Cenomanian rather than Lower.

(iii) Localities of ammonites suggesting the Turonian.-At loc. CAS. 33706, in a conglomerate, "1 mile south of acquaduct, Arroyo del Valle, Alameda County", there are

Puzosia (s.l.) sp.

Sciponoceras kossmati (NowaK)

which suggest the Lower Turonian.

The Upper Turonian is represented by loc. LSJU. 2735, on a hill south of Arroyo del Valle (Text-fig. 20), where L. W. FUnkHousER obtained:

Neophylloceras ramosum (MEEK)

Subprionocyclus normalis (ANDERSON)

(iv) Evidence for the Lower Senonian (Coniacian and Santonian) is poor in the Bay area. In the geological map of Tesla Quadrangle, however, a conformable series of strata is shown between the above mentioned locality of Upper Turonian and the Campanian localities of Arroyo del Valle. It is noted that a conglomerate is indicated at a level somewhat higher than the Subprionocyclus-bearing bed.* (v) Localities of ammonites suggesting the Campanian.-In Arroyo del Valle there are localities called SMITH or JORDAN ranch, including LSJU. 1840, LSJU. 2732, LSJU. 2734, and CAS. 31245. They are in a unit of siltstones and sandstones in alternation. The species, in my identification, are as follows:

Neophylloceras ramosum (MEEK)

Desmophyllites diphylloides (FORBES)

Metaplacenticeras pacificum ( $\mathrm{SMITH}$ )

Gaudryceras sp.

Baculites sp. aff. B. anceps LAMARCK

Baculites inornatus MEEK

At loc. LSJU. 3357 [=TM. 702], from a calcareous part in the massive sandstone occupying the higher part of the Cretaceous section of Arroyo del Valle, JONES, GRAHAM, SCHENCK, and I found

Baculites rex ANDERSON

which suggests the uppermost Campanian or Maestrichtian.

Somewhat separated from the Cretaceous area of Arroyo del Valle, there is another outcrop in the northern part of Tesla Quadrangle. "Redmont cut" of Western Pacific Railroad is in this part, where HALL and AMBrose (1916) reported an ammonite, Submortoniceras templetoni (HALL and AMBRoSE). Its single type (holotype), is close to, and may be a relatively coarsely ornamented and widely umbilicate variety of, Submortoniceras chicoense (Trask). The

* After completing paleontologic descriptions, I received a specimen on loan from Dr. D. L. JoNes, who identified in the collection of Ivan CoBURN from a locality south of Antioch and northeast of Mt. Diablo, in Contra Costa County:

Baculites yokoyamai ToKUNAGA and SHIMIZU.

On studying the specimen, I agree with him in this identification. It suggests the Coniacian. 
same locality has received loc. no. 33728 (CAS.), XIII of HUEY (1948), and LSJU. 3356 [=TM 701]. The exposed rocks are shales with frequently interbedded, thin sandstones. The fossils are secondarily crushed, but I have identified the following species:

Pachydiscus cf. neevesi WhItEAVES

Submortoniceras sp.

Exiteloceras (?) sp.

Baculites cf. chicoensis TRAsk

The fossiliferous unit, exposed at Redmont cut, is thus correlated in age with the

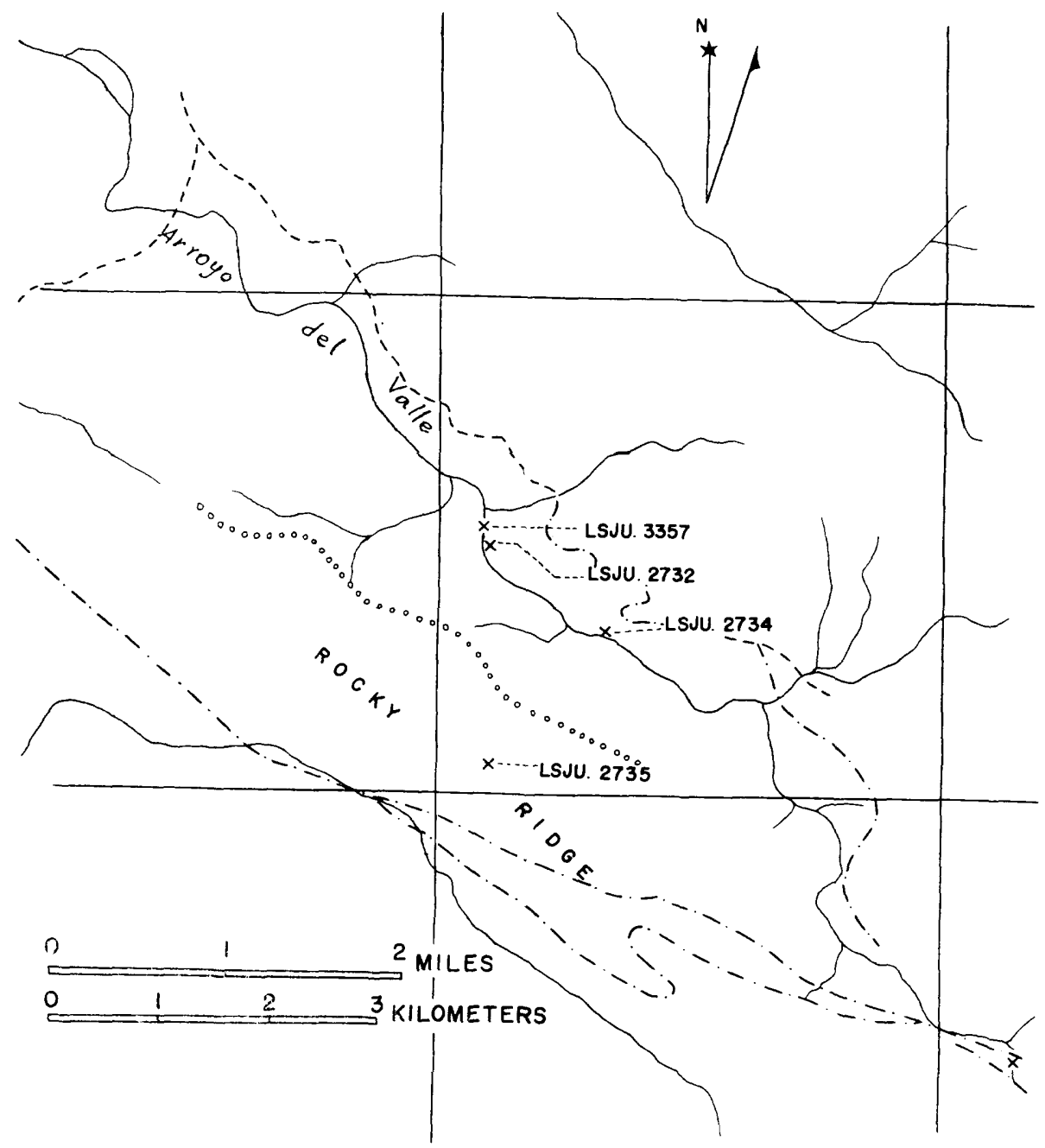

Fig. 20. Map of the Arroyo del Valle area, Alameda County. Dotted line: boundary of Tertiary and Cretaceous, broken line: fault, a train of small circles: conglomerate in the Upper Cretaceous, as indicated in HuEY's (1948) geologic map of Tesla Quadrangle. 
upper half of the Chico formation of Chico Creek, although they are dissimilar in rock-facies.

In Byron Quadrangle, east of Mt. Diablo, there is an indication of the Upper Campanian at loc. CAS. 29086. The evidence is

Baculites inornatus MEEK

At loc. CAS. 33693, in a shaly unit of the Mt. Diablo Quadrangle, there is another indication of the Upper Campanian:

Baculites cf. B. occidentalis MEEK

I do not know the stratigraphic relationship between the Calycoceras-bearing Cenomanian beds and Baculites-bearing Campanian beds in Mt. Diablo Quadrangle.

Baculites inornatus MEEK has recently been confirmed by Dr. PACKARD from a unit of mudstone discovered at a locality near the golf-link in the campus of Stanford University. He showed me well preserved specimens.

The type locality of Ammonites fraternus GABB (1869, p. 137, pl. 23, fig. 15a, b) was recorded as near Benicia, Solano County, but from what part of the Cretaceous beds of Benicia it came has not been made clear. GABB's original specimen is now preserved at the Academy of Natural Sciences of Philadelphia. Its matrix is a calcareous sandstone. It is an immature example of Canadoceras, possibly of C. newberryanum (MEEK) or C. yokoyamai (JIMBo), but it is too imperfectly preserved to decide a synonymy, unless better preserved topotypes could be examined. Anyhow the occurrence of Canadoceras suggests the existence of the Campanian in this part of the Bay area.

(vi) Localities of ammonites suggesting the Maestrichtian.-One of the specimens described by GABB (1864, pl. 14, fig. 29, 29a) under Baculites chicoensis is Eubaculites ootacodensis (STOLICZKA), as I have mentioned in the paleontological part (Pt. I, p. 166, pl. 44, fig. 2a-c; text-fig. 84). It is recorded from "Martinez, Contra Costa County", but the actual point has not been confirmed. The matrix is a calcareous sandstone. The same species occurs in the Tierra Loma shale of the Moreno formation on west side of the San Joaquin Valley.

Baculites subcircularis ANDERSON came from loc. CAS. 28442, Briones Creek, Contra Costa County. As this is based on a small fragment, I cannot give appropriate comments, but it seems to resemble $B$. (?) teres FonBEs.

According to the literature (e.g. HuEY, 1948) the equivalent of the Moreno formation is recorded as occurring in a limited part of the Bay Area, but I have not seen any ammonites from it.

\section{A few areas in Mendocino, Sonoma, and Monterey Counties, in the Coastal Region}

(a) Gualala and vicinity, Mendocino-Sonoma Counties.-The Gualala [Wallala] group has been known since WHITE (1885b) reported the faunule containing Coralliochama orcutti WHITE. WEAVER (1944) added the geological details of the area. The age of the Coralliochama beds given by recent authors (WEAVER, 1944 ; Durham and Kirk, 1950; DUrham and Allison, 1956; Anderson, 1958) 
is the higher part of the Upper Cretaceous, probably Maestrichtian. I had an opportunity of examining KIRK's collections of ammonites from locs. UC. A-4896 and UC. A-6293. The specimens are highly deformed, but are comparable with Didymoceras [Nostoceras ?] sp. cf. hornbyense (WHITEAVES) Diplomoceras (?) sp.

which suggest an age near the boundary of Campanian and Maestrichtian.

(b) Covelo area, Mendocino County.-CLARK (1940) reported the geology of this area and ANDERSON (1958, p. 70) listed his specimens, suggesting again the higher part of the Upper Cretaceous. I did not examine the ammonites of ClarK's collection, except for one from loc. UC. A-6598. That is

Pseudophyllites cf. indra (FoRBES)

It is close to an example from the Nanaimo group (Usher, 1952, p. 57, pl. 3, figs. 2-13; pl. 31, figs. 15-17). It was labelled as Parapachydiscus, an obvious misidentification. A similar misidentification happened in another case of Pseudophyllites indra (FoRBEs) from the Rosario formation of Baja California. The specimen was illustrated as "Parapachydiscus catarinae" ANDERson and HaNna (1938, pl. 3, figs. 2, 3 only).

(c) Slate Hot Springs, Monterey County.-NomLANd and Schenck (1932) reported about the Cretaceous beds at Slate Hot Springs, where a baculites was discovered. According to the authors REESIDE considered it as belonging to the group of Baculites anceps LAMARCK. The specimen itself is an impression of a baculites on a black argillite and is indeed comparable with that group. In view of the stratigraphic occurrence of Baculites aff. $B$. anceps in other better investigated Cretaceous areas of California (see p. 136 of Part I) the Upper Campanian is suggested. 


\section{Collecting Localities}

In this chapter I compile in a list all the registered localities of Upper Cretaceous ammonites from California and adjacent area which have been at my disposal. The list also includes localities of some Upper Albian ammonites which are mentioned in the Chapter "Notes on stratigraphy."

The locality data have been offered by courtesy of the curators of the museums or type-rooms of the following institutions where the record-books or cards are kept.

CAS. Department of Geology, California Academy of Sciences, San Francisco

CIT. California Institute of Technology, Pasadena (A copy of the recordbook is now kept at the Department of Geology, University of California, Los Angeles)

LSJU. School of Mineral Sciences, Leland Stanford Junior University, Stanford

SOC. Laboratory of Paleontology, Shell Oil Company, Seattle

UC. Museum of Paleontology, University of California, Berkeley

UCLA. Department of Geology, University of California, Los Angeles

I am much indepted to Dr. Leo G. Hertlein, Professor W. P. Popenoe, Dr. A. Myra Keen, Messrs. M. V. Kirk, J. H. Peck, Jr., and Takeo Susuki who have helped me in completing the list. The data are rearranged into the following items for each locality.

Number [=locality number], with prefix of one of the above institution

Area, indicating the names of a topographic sheet (map quadrangle), county, and the general area as classified in "Introduction" (see Part I, p. 95-96)

Loc. [=location], describing the details of the location as exactly as possible

Str. [= stratigraphic] position, so far as the record is available

Fossils: Specific names of ammonites which I have identified. The one with a star mark $(*)$ is represented by the specimen which was figured in Parts I and II. Associated species of Inoceramus may be indicated.

Age: Geological age indicated or suggested by the above species

Coll.: name (s) of a collector (or collectors)

Remarks, if necessary

In accordance with the original descriptions in record-books, the distance or thickness is written in feet or miles instead of meters or kilometers. A reader may calculate from the equivalency, 1 foot $=0.305$ meter, or 1 mile $\div 1.6$ kilometer.

CAS. 252

Area: Corona Quad. (1:125000), Orange Co., Santa Ana Mts.

Loc.: Silverado Canyon, no further information

Str. position: "Basal Chico beds" (Calcareous fine-sandstone of presumably Baker Canyon member)

Fossils: Subprionocyclus sp. 
Age: Upper Turonian

Coll.: F. M. ANDERSON

CAS. 252 (different from another CAS. 252)

Area: Corona Quad. (1:125000), Orange Co., Santa Ana Mts.

Loc.: Black Star Canyon, Santiago Creek

Str. position: No record; black shale

Fossils: Desmophyllites cf. diphylloides (FORBES) [=Kotoceras richardsoni ANDERson]

Age: Campanian (?)

Coll.: No record

CAS. 252a

Area: Corona Quad. (1:125000), Orange Co., Santa Ana Mts.

Loc.: Santiago Canyon, no further information

Str. position: No record

Fossil: Pachydiscus cf. buckhami UsHeR

Age: Campanian

Coll.: Miss Davidson

CAS. 365

Area: Marysville Buttes and Vicinity Quad., Sutter Co., Sacramento Valley

Loc.: SE. $1 / 4$ of NE. 1/4, sec. 35, T.16N., R.1E.; 5/8 mile S. of South Butte on ridge

Str. position: No record; see JoHnson in KIRBY, 1943, p. 301

Fossil: Pachydiscus sp. immature ef. egertoni (FORBES) [=Pachydiscus ganesa (FORBES) ]

Age: Lower Maestrichtian or Upper Campanian

Remarks: There are two kinds of rocks in the same tray under one label. An ammonite is in a fine, silty calcareous nodule, while another specimen is in a sandstone. Possibly two specimens of different localities were mixed here.

CAS. $444[=455]$

Area: Hornbrook Quad., Siskiyou Co., N. California

Loc.: No precise record of sec., T. \& R.; "Near Henley" or " $1 / 2$ mile west of Henley"

Str. position: No precise record; presumably fairly higher part in the section of this area; one label shows " 400 feet below the zone of Metaplacenticeras"

Fossils: Tetragonites (Saghalinites) henleyense (ANDERSON), Desmophyllites diphylloides (FORBES), Eupachydiscus haradai haradai (JIMBo) $*$ [=Fagesia klamathensis ANDERSON (holotype)],Anapachydiscus (?) siskiyouensis (ANDERSON) [=Fagesia siskiyouensis ANDERSON]

Age: Campanian (?)

Coll.: F. M. ANDERSON

CAS. $444 \mathrm{~A}$

Area: Hornbrook area, Siskiyou Co., N. Califorria

Loc.: Rocky Gulch, 1/8 mile above Gilson Quartz Mill, 2 miles S. W. of Hornbrook

Str. position: No precise record

Fossils: Subprionocyclus cf. neptuni (GEINITZ) [=Oregoniceras gillsoni ANDERSon], Scalarites sp., Inoceramus cf. incertus (Jімво)

Age: Upper Turonian

Coll.: B. L. CUnNingham

CAS. 444B

Area: Hornbrook Quad., Siskiyou Co., N. California 
Loc.: South of Klamath River, $1 / 2$ mile south of Hornbrook (in calcareous sandstone) Str. position: No precise record

Fossils: Metaplacenticeras pacificum (SMITH), Inoceramus vancouverensis SHUMARD Age: Upper Campanian

Coll.: No record

CAS. 445

Area: $\mathrm{SW}$. Oregon

Loc.: "49 Mines, 2 miles south of Phoenix"

Str. position: No precise record

Fossils: Subprionocyclus neptuni (GEINITZ) [=Oregoniceras siskiyouense (ANDERSON), Oregoniceras kneighteni (ANDERSON), and several other species of Oregoniceras ANDERSON], Tetragonites glabrus (JIMBO) [=Lytoceras (Tetragonites) jacksonensis ANDERSON], Scalarites mihoensis WRIGHT \& MATSUmoto, Hyphantoceras (?) irregulare ANDERSON, Scaphites condoni ANDERSON, Tragodesmoceras ashlandicum (ANDERSON) [=Pachydiscus ashlandicum (ANDERSON), Pachydiscus oregonensis ANDERSON]

Age: Upper Turonian

Coll.: F. M. ANDERSON

CAS. $445(?) *$

Area: SW. Oregon

Loc. "49 Mines, 2 miles south of Phoenix" (This is doubtful for this particular specimen.)

Str.position: No precise record available

Fossil: Calycoceras stoliczkai CoLLIGNoN* [=Mantelliceras oregonense ANDERson, 1958, holotype; Calycoceras (Metacalycoceras) auspicium ANDERson, 1958, holotype]

Age: Upper Cenomanian

Coll.: E. L. PACKARD

CAS. $445 \mathrm{~A}$

Area: SW. Oregon

Loc.: "FIтCH (formerly SмITH) ranch, 3 miles west of Phoenix"

Str.position: No precise record

Fossils: Subprionocyclus branneri (ANDERSON)*, Hyphantoceras (?) ceratopse ANDERSON, Otoscaphites perrini (ANDERSON)

Coll.: F. M. ANDERSon (?)

CAS. $445 \mathrm{C}$

Area: SW. Oregon

Loc.: "Dark Hollow, an old Pioneer road, 4 miles SW. of Phoenix"

Str. position: No precise record

Fossil: Calycoceras stoliczkai CoLlignon [=Mantelliceras oregonense ANDERson, 1958, pl. 8, fig. 4, 4a (paratype)] (specimen missing, revision based on the figures and holotype)

Age: Upper Cenomanian

Coll.: E. L. Packard (?)

CAS. 455 [See CAS. 444]

CAS. $455 \mathrm{~A}$

Area: Hornbrook Quad., Siskiyou Co., N. California

Loc.: Sidney RICHARDSON ranch, 4 miles north of Montague 
Str.position: No record

Fossils: Damesites damesi intermedius MATSumoto [=Kotoceras richardsoni ANDERsoN, 1958, holotype], Otoscaphites sp., Inoceramus cf. uwajimensis YeHARA

Age: Probably Coniacian

Coll.: F. M. ANDERSON

CAS. 462

Area: Joaquin Rock Quad., Fresno Co., W. San Joaquin Valley

Loc.: E. 1/2, sec. 17, T. 19S., R. 15E.; North of Coalinga (sec. number doubtful)

Str. position: Moreno shale (?) (white limy nodule with foram.)

Fossil: Eubaculites (?) sp.

Age: Maestrichtian (?)

Coll.: F. M. ANDERSON

CAS. 463 [See CAS. 2362]

CAS. $465^{*}$

Area: Ono Quad., Shasta Co., NW. Sacramento Valley

Loc.: No precise record

Str. position: No precise record; "Horsetown" in the record book, but doubtful

Fossil: Collignoniceras woollgari (MANTELL) (immature) [=Calycoceras (Metacalycoceras) auspicium ANDERSON, 1958, paratype]

Age: Turonian

Coll.: F. M. ANDERSON

CAS. 699

Area: Los Angeles Co., Simi Hills

Loc.: Bowers Canyon; no further information. According to Popenoe, this is the same locality as CIT. 1159.

Str. position: No record

Fossils: Baculites cf. inornatus MEEK, Inoceramus cf. subundatus MEEK

Age: Campanian (?)

Coll.: No record

Remarks: Read Simi Hills for St. Monica Mountain in the description (occurrence) of Baculites inornatus MeEK (Part I, p. 160)

CAS. 1125

Area: Oroville Quad., Butte Co., E. Sacramento Valley

Loc.: One mile west of Pentz ranch, south of road to Chico

Str. position: Chico formation (s.s.)

Fossils: Canadoceras ef. newberryanum (MEEK) [=Canadoceras aff. fraternum (GABB) ex. ANDERSON], Submortoniceras chicoense (TRASK) (narrowly umbilicate and much compressed form) [=M. (S.) pentzanum ANDERSON], Submortoniceras studleyi (ANDERSON) [=? "Butticeras buttense ANDERSON"], Baculites chicoensis Trask, Bostrychoceras cf. declive (GABB)

Age: Campanian

Coll.: G. D. HanNa \& L. G. Hertlein; F. M. ANderson

CAS. 1173

Area: San Diego Co., S. California

Loc.: "At Point Loma below lighthouse on beach on east side of Point"

Str. position: No record; Matrix is calcareous siltstone.

Fossils: Baculites cf. lomaensis ANDERSON

Age: Lowest Maetrichtian or highest Campanian

Coll.; L. G. HeRTLEIN, 8/11/1927 
CAS. 1291

Area: Lodoga Quad., Colusa Co., W. Sacramento Valley

Loc.: No record of sec., T. \& R., but probably near boundary line of sec. 32 and 33, T. 18N., R. 4W.; Peterson ranch, 4 miles north of Sites

Str. position: Just below the Venado sandstone formation

Fossils: Desmoceras (Pseudouhligella) dawsoni WhIteAve [=Beudanticeras alamoense Anderson], Pachydesmoceras colusaense (ANDErson), Pseudohelicoceras petersoni (ANDERSON) (holotype)

Age: Upper Albian

Coll.: No record

CAS. 1293A

Area: Millville Quad. (Redding area), Shasta Co., NE. Sacramento Valley

Loc.: No record of sec., T., \& R.; "1 mile north of Frazier Corners"

Str. position: Presumably somewhere in Member II of PopenoE

Fossils: Neophylloceras cf. ramosum (MEEK), Mesopuzosia sp. cf. M. pacifica MATSUмото or $M$. indopacifica (Kossmat), Hyphantoceras sp. indet., Bostrychoceras occidentale ANDERSON (holotype), Scaphites pittensis ANDERson, 1958, pl. 19, fig. 4, 4a (holotype) [related to S. pseudoaequalis YABE], Otoscaphites sp., Inoceramus cf. teshioensis Nagao and Matsumoto

Age: Turonian

Coll.: No record

CAS. 1343

Area: Mt. Vaca Quad., Solano Co., W. Sacramento Valley

Loc.: E. 1/2, sec. 10, T. 7N., R. 2W.; "north end of Pleasants Valley"

Str. position: No record

Fossil: Gaudryceras cf. denmanense WhITEAVES

Age: Upper Senonian

Coll.: F. M. ANDERSON

CAS. 1345

Area: Redding Quad., Shasta Co., NW. Sacramento Valley

Loc.: SE. $1 / 4$ of SW. $1 / 4$ of sec. 30, T. 31N., R. 5W.; Jackass Flat

Str. position: No record

Fossil: Hulenites onona (ANDERSON) [=Puzosia (Parapuzosia) onona ANDSRSON, 1958 = Puzosia onona ANDERson, 1938 holotype]

Age: Albian

Coll.: F. M. ANDERSON

CAS. 1346

Area: Ono Quad., Shasta Co., NW. Sacramento Valley

Loc.: No record of sec., T. \& R.; North Fork of Cottonwood Creek, 0.5 mile (sometimes written as 0.6 mile) above the mouth of Hulen Creek

Str. position: Conglomerate with silty matrix

Fossils: Desmoceras (Pseudouhligella) dawsoni WHITEAves [=Beudanticeras alamoense ANDERSON, 1958, holotype, pl. 5, fig. 2, 2a; Beudanticeras argonauticum ANDerson, 1958, holotype, pl. 9, figs. 1, 2], Pachydesmoceras colusaense (ANDERSON) [=Puzosia (Parapuzosia) colusaensis (ANDERSON)], Mortoniceras kiliani (LAsswitz) [=Pervinquieria sylvana Anderson, 1958, holotype, pl. 4, figs. 2, 3], Anagaudryceras cf. sacya (FORBES)

Age: Upper Albian

Coll.: F. M. Anderson 
CAS. 1346 A

Area: Ono Quad., Shasta Co., NW. Sacramento Valley

Loc.: No precise record; with a doubtful record: "1 mile above mouth of Hulen Creek"

Str. position: Uncertain

Fossil: Desmoceras (Pseudouhligella) barryae (ANDERSON) [ $=$ Desmoceras (Latidorsella) barryae ANDERSON, 1958, holotype]

Age: Uncertain; possibly Lower Cenomanian or Upper Albian

Coll.: F. M. ANDERSON

CAS. 1467 plus 1467 A

Area: Capay Quad., Yolo Co., W. Sacramento Valley

Loc.: Enos Canyon, W. of Winters

Str. position: No record; limy nodules

Fossils: Neophylloceras ramosum (MEEK), Desmophyllites diphylloides (ForBes) [=Desmophyllites yoloensis ANDERSON, 1958, holotype], Hauericeras sp. juvenile, Metaplacenticeras pacificum SMITH, Pseudoxybeloceras (?) cf. lineatum (GABB), Inoceramus subundatus MEEK

Age: Upper Campanian

Coll.: RAMBKe (for 1467A)

CAS. 1552

Area: Cholame Quad. $(1: 125000)$, Kern Co., SW. San Joaquin Valley

Loc.: 500 feet W. of center of sec. 28, T. 26S., R. 18E.; north end of Shale Hills, SW. side of Antelope Valley

Str. position: No record of formational name

Fossils: Desmophyllites diphylloides (ForBes) [ $=$ D. selwynianus (Whiteaves) ], [D. siskiyouensis Anderson, 1958, paratype], Tetragonites popetensis Y $\mathrm{ABE}$ [ $=$ Lytoceras (Tetragonites) kernense ANDERSON, 1958, holotype and paratype], Baculites rex ANDERSON

Age: Upper Campanian or Lower Maestrichtian

Coll: G. D. HANna \& J. H. Show on information given by Dr. G. Henny of Shell Oil Co., April, 1929

CAS. 1690

Area: Ono Quad., Shasta Co., NW. Sacramento Valley

Loc.: No record of sec., T. \& R.; 2 miles below the mouth of Hulen Creek, North Fork of Cottonwood Creek, north of Gas Point

Str. position: No formational name; in greenish grey, silty shale

Fossils: Mesopuzosia sp., Romaniceras sp. cf. deverioide (Grossouvre), Collignoniceras sp. juvenile (resembling young of $C$. woollgari), Gaudryceras cf. denseplicatum (Јімво), Tetragonites glabrus (Јімво) (All, except for the last one, are poorly preserved.)

Age: Turonian (probably middle part)

Coll.: F. M. ANDERSON

CAS. $1690 \mathrm{~A}$

Area: Ono Quad., Shasta Co., NW. Sacramento Valley

Loc.: 1/2 mile west of TiptoN's house, north of Gas Point, North Fork of Cottonwood Creek, Shasta County

Str. position: No precise record; black, compact, calcareous nodule

Fossil: Plesiovascoceras sp. ("Fagesia californica ANDERSON")

Age: Lower Turonian

Coll.; F. M. ANDERSON 
CAS. 1790

Area: Coalinga Quad., Fresno Co., W. San Joaquin Valley

Loc.: North side of a canyon, $1 / 2$ mile E. of Oil City

Str. position: "Top of Moreno" (resembling Marca shale)

Fossils: Baculites rex Anderson, a coiled ammonite (indet, possibly Saghalinites sp.)

Age: Maestrichtian

Coll.: G. D. HanNa, 1929

CAS. 2233

Area: Ono Quad., Shasta Co., NW. Sacramento Valley

Loc.: Cottonwood area, a gulch, $1 / 2$ mile southeast of mouth of Hulen Creek, 2 miles NW. of Gas Point

Str. position: No precise record

Fossils: Neophylloceras seresitense (PERvINQUiÈre) [= Phylloceras velledae MiCHELIN, ANDERSon, 1958, p. 180, pl. 16, fig. 4, 4a], Desmoceras (Pseudouhligella) ? hindsi (ANDERson) (holotype), Eogunnarites n. sp., Calycoceras cf. newboldi (Kossmat) [=C. (Eucalycoceras) newboldi (Kossmat), ANDERSON, 1958]

Age: Cenomanian

Coll.: F. M. ANDERSON

CAS. 2245

Area: Ono Quad., Tehama Co., NW. Sacramento Valley

Loc.: No record of sec., T. \& R.; "on Dry Creek, west of Rosewood" or "15.1 miles southeast of Beegum."

Str. position: No record

Fossils: Parapuzosia (Austiniceras) ? giganteum (ANDerson) (holotype), Jimboiceras cf. planulatiforme (Jімво) [=Puzosia (Eocanadoceras) hannai ANDERSON, 1958 (holotype)], Coilopoceras hyatti ANDERson (holotype)

Age: Turonian (?)

Coll.: J. A. TAFF \& C. M. CRoss

CAS. 2259

Area: Carbona Quad., San Joaquin Co., W. San Joaquin Valley

Loc.: NE. $1 / 4$ of NE. $1 / 4$, sec. 6, T. 4S., R. 5E.; Hetch-Hetchy tunnel, 10000-10500 feet from mouth

Str. position: No formational name; shale

Fossils: Damesites cf. hetonaiensis fresnoensis ANDErson, Pachydiscus (s.s.) sp., Pachydiscus (Neodesmoceras) (?) sp., Nostoceras sp., Baculites sp.

Age: Lower Maestrichtian (?)

Coll.: F. A. MENKEN

CAS. 2324

Area: Coalinga Quad., Fresno Co., W. San Joaquin Valley

Loc.: W. $1 / 2$ of sec. 16, T. 21S., R. 14E.; Walthan Creek, 1.6 miles E. of Parkfield road, north side of Creek

Str. position: No record; presumably Lower Waltham formation from lithology and from location; several horizons mixed (?)

Fossils: Acanthoceras cf. sherborni Spath [="Ac. cunningtoni SHARPE on ANderson's label], (calcareous shale matrix), Mantelliceras ? cf. lecontei (ANDERson) [="Pervinquieria inflata", ANDERSON, 1958, pl. 8, fig. 6] (partly sandy, partly shaly matrix), Anagaudryceras cf. sacya (Forbes) (relatively coarse-grained sandstone matrix), Turrilites cf. costatus LAMARCK $[=$ Turrilites pachecoensis ANDERSON (unfigured specimen)] 
Age: Cenomanian

Coll.: G. D. HaNnA

CAS. 2336

Area: Lodoga Quad., Colusa Co., W. Sacramento Valley

Loc.: No record of sec., T. \& R.; but, from the description of locality should be an exposure of shale on cut bank in Funks Creek, 3 miles north of Sites, 1 mile below PETERSON's ranch house, and $1 / 4$ mile $\mathrm{W}$. of the gorge through sandstone

Str. position: In shale unit, called the "Antelope shale"

Fossils: Calycoceras cf. stoliczkai Collignon*, also Calycoceras sp., indet. cf. boulei COLLIGNON (?)

Age: Cenomanian (middle or upper part)

Coll.: G. D. HanNa, 1931

CAS. 2361 [ = CAS. 31593]

Area: Joaquin Rock Quad., Fresno Co.

Loc.: Joaquin Ridge, NW. of Oil City (see CAS. 31593)

Str. position: No record; presumably Ragged Valley shale (see CAS. 31593)

Fossils: Damesites hetonaiensis fresnoensis (ANDERSON), Hauericeras rembda (FORBES) [=Hauericeras churchi ANDERSon, 1958, holotype], Anagaudryceras sp., Gaudryceras (Vertebrites) cf. kayei (FORBES) [=Lytoceras (Gaudryceras) birkhauseri ANDERSON, 1958, holotype], Baculites lomaensis ANDERSON* (type locality)]

Age: Lower Maestrichtian

Coll.: C. C. ChURCH, March, 1931

CAS. $2362[=463]$

Area: Coalinga Quad., Fresno Co., W. San Joaquin Valley

Loc.: E. $1 / 2$, sec. 4, T. 20S., R. 14E.; Los Gatos Creek

Str. position: No record; should be somewhere in "Ragged Valley shale formation"

Fossils: Damesites hetonaiensis fresnoensis ANDERSon [type locality], Pachydiscus cf. egertoni (FORBES) [= Parapachydiscus coalingensis ANDERSON, 1958, holotype], Pachydiscus (Neodesmoceras) (?) sp. aff. P. (N.) catarinae (ANDERson and HANNA) [transitional from Anapachydiscus californicus (Y $\mathrm{ABE}$ )], Anagaudryceras mikobokense ColLIGNoN, Gaudryceras (Vertebrites) kayei (FoRBES) $[=$ Lytoceras (Gaudryceras) coalingense ANDERSON, 1958, holotype], Baculites lomaensis ANDERSON

Age: Lower Maestrichtian or uppermost Campanian

Coll.: J. A. TafF, C. C. Church, C. M. Cross, \& G. D. Hanna

CAS. 2362 (different from another CAS. 2362)

Area: Coalinga Quad., Fresno Co., W. San Joaquin Valley

Loc.: Sec. 9, T. 20S., R. 14E.; S. branch of Los Gatos Creek

Str. position: No record; should be somewhere in "Ragged Valley shale formation", possibly slightly lower than another 2362

Fossils: Pachydiscus ef. ootacodensis (STOLICZKA), Tetragonites popetensis YABE, Didymoceras hornbyense (WHITEAVES), D. vancouverense (GABB), Baculites occidentalis MeEK, Inoceramus cf. subundatus MEEK

Age: Upper Campanian

Coll:: Several persons; different dates

CAS. 2366

Area: Coalinga Quad., Fresno Co., W. San Joaquin Valley

Loc.: W. 1/2, sec. 25, T. 19S., R. 14E.; 8 miles north of Coalinga

Str. position: "Ragged Valley shale", below the "Brown Mountain sandstone" 
Fossils: Damesites hetonaiensis fresnoensis (ANDERSON)

Age: Probably Lower Maestrichtian

Coll:: G. D. HaNna, 1930

CAS. 2368

Area: Coalinga Quad., Fresno Co., W. Sacramento Valley

Loc.: Center of sec. 4, T. 20S., R. 14E.; left bank of Los Gatos Creek

Str. position: "Ragged Valley shale" (exact horizon uncertain)

Fossils: Damesites hetonaiensis fresnoensis (ANDERSON)

Age: Lower Maestrichtian (?)

Coll.: Max BirkhaUSer, 4/8/1931

CAS. 13289

Area: San Diego Co., S. California

Loc.: Point Loma

Str. position: No record; fine, sandy, calcareous nodule

Fossil: Menuites cf. menu (Forbes)

Age: Upper Senonian

Coll.: No record

CAS. 23553

Area: E. Sacramento Valley

Loc.: "Folson"

Str. position: No record

Fossil: Inoceramus cf. subundatus MEEK

Age: Campanian

Coll.: E. D. DREW, 1935

CAS. 25730

Area: Rumsey Quad., Colusa Co., W. Sacramento Valley

Loc.: No record of sec., T. \& R.; Sand Creek (presumably close to LSJU. 3169)

Str. position: Presumably basal part of Forbes formation

Fossils: Patagiosites arbucklensis (ANDERSON) [type locality], Gaudryceras cf. striatum (JIMBo) [=Parapachydiscus cortinaensis ANDERSON, holotype], Inoceramus schmidti MICHAEL

Age: Campanian (middle part)

Coll.: H. L. DobBins

CAS. 26878

Area: Carbona Quad., San Joaquin Co., W. San Joaquin Valley

Loc.: No record of sec., T. \& R.; Hospital Canyon, 10 miles S. of Tracy

Str. position: No reliable record; "beds 600 feet below the Moreno", which is doubtful

Fossils: Baculites occidentalis MEEK, Diplomoceras sp., Solenoceras (?) sp., Inoceramus sp.

Age: Upper Campanian (?)

Coll.: F. M. ANDERSON

CAS. 27835

Area: Paradise Quad., Butte Co., E. Sacramento Valley

Loc.: Chico Creek (for very point see TAFF, HANNA, \& Cross, 1940)

Str. position: Chico formation (s.s.) (lower-middle part)

Fossils: Baculites capensis Woods [=Baculites buttensis ANDERson, 1958, holotype], Hauericeras angustum YABE [=Hauericeras mickeyi ANDERSON, 1958, holotype]

Age: Santonian

Coll.: J. A. TAFF, G. D. Hanna, \& C. M. Cross 
CAS. 27837

Area: Paradise Quad., Butte Co., E. Sacramento Valley

Loc.: Big Butte Creek (for the very point see TAFF, HANNA, \& CRoss, 1940)

Str. position: Chico formation (s.s.)

Fossil: Baculites chicoensis Trask

Age: Campanian (probably lower part)

Coll.: TaFF, Hanna, \& Cross

CAS. 27838

Area: Paradise Quad., Butte Co., E. Sacramento Valley

Loc.: Chico Creek (for a very point, see TAFF, HANNA, \& Cross, 1940), 3.1 miles by road south of bridge of Mickey place

Str. position: Chico formation (about 1400 feet from the base; relatively upper part of the formation)

Fossils: Pachydiscus buckhami UsHer [=Parapachydiscus aff. gabbi ANDERSON], Pachydiscus neevesi WHITEAves [= Parapachydiscus bidwelli ANDERSON (holo- and paratypes)], Submortoniceras chicoense (TRASK) [=Mortoniceras (Subm.) chicoense, ANDERSON; $M$. (S.) randalli ANDERSON, 1958, holo- and paratypes; $M$. (S.) pentzanum ANDERSon, 1958, holotype], Submortoniceras studleyi (ANDERSON) [=Butticeras studleyi ANDERSON], Baculites chicoensis TrAsk, Pseudoxybeloceras cf. lineatum (GABB) [=Oxybeloceras taffi ANDERSON, 1958, holotype]

Age: Campanian (probably lower part)

Coll.: TafF, HanNa, \& Cross

CAS. 27854

Area: Mt. Boardman Quad., Stanislaus Co., W. San Joaquin Valley

Loc.: E. side SE. 1/4, sec. 36, T. 7S., R. 6E.; Orestimba Creek, N. side of canyon

Str. position: "Boulder in conglomerate at the base of Panoche group (of ANDERSON)"

Fossil: Hyphantoceras oshimai (YABE) [=Didymoceras orestimbense ANDERSON, 1958, holotype]

Age: Upper Turonian or Coniacian, suggested

Coll.: J. A. TAFF, G. D. Hanna, \& C. M. Cross, May 1934

CAS. 27858

Area: Pacheco Pass Quad., Stanislaus Co., W. San Joaquin Valley

Loc.: Center of S. 1/2, SE. 1/4, sec. 3, T. 9S., R. 7E.; from bluff on NE. side Quinto Creek

Str. position: Basal conglomerate (resembling the Papanatas conglomerate of the Panoche Hills)

Fossil: Turrilites costatus LAMARCK [=Turrilites pachecoensis ANDERSON, 1958, holotype]

Age: Cenomanian

Coll.: J. A. TAFF, G. D. Hanna, \& C. M. Cross, 5/17/1934

CAS. $28104(=25627)$

Area: Mt. Diablo Quad., Contra Costa County, Bay area

Loc.: SE. $1 / 4$, sec. 8, T. 1S., R. 1E., Curry Creek (Curry Canada; Curry Canyon)

Str. position: Uncertain; "at horizon of Acanthoceras whitei"

Fossil: Calycoceras ef. orientale Matsumoto, SAIto, \& Fukada [=Calycoceras diabloense ANDERSON, 1958, holotype]

Age: Cenomanian

Coll.: F. M. ANDERSON

CAS. 28173

Area: Paradise Quad., Butte Co., E. Sacramento Valley 
Loc.: Chico Creek, below the middle of the exposed section

Str. position: Chico formation (s.s.)

Fossil: Hyphantoceras venustum (YABE) [= Bostrychoceras buttense ANDERSon, 1958, holotype]

Age: Santonian (from its stratigraphic position and also occurrence in Japan)

Coll.: J. A. Taff, G. D. Hanna, \& C. M. Cross

CAS. 28175

Area: Pacheco Pass Quad., Merced Co., W. San Joaquin Valley

Loc.: Center of NE. 1/4, sec. 12, T. 9S., R. 7E.; Quinto Creek

Str. position: No formational name; sample no. 1 from ammonite horizon, 300 feet below a conglomerate bed in sandy shale

Fossil: Collignoniceras cf. woollgari (MANTELL) [="Prionotropis bakari ANDERSON"] (immature and middle-aged)

Age: Turonian (middle part)

Coll.: TAFF \& CROSS, 1/8/1935

CAS. 28304

Area: Joaquin Rock Quad., Fresno Co., W. San Joaquin Valley

Loc.: SE. 1/4, sec. 6, T. 19S., R. 15E.; Domegine Creek from gully

Str.position: No record

Fossils: Baculites lomaensis ANDERson (a number of specimens), Pachydiscus sp.

Age: Lower Maestrichtian or uppermost Campanian

Coll.: TAFF \& CRoss, 3/28/1935

CAS. 28305

Area: Coalinga Quad., Fresno Co., W. San Joaquin Valley

Loc.: S. $1 / 2$, sec. 10 , T. 20S., R. 14E.; first shale bank on south side of Los Gatos Creek

Str. position: Ragged Valley shale

Fossil: Baculites occidentalis MEEK

Age: Upper Campanian

Coll.: J. A. TafF, G. D. Hanna, C. C. Church, \& C. M. Cross

CAS. 28325

Area: Orestimba Quad., Stanislaus Co., W. San Joaquin Valley

Loc.: NE. 1/4, sec. 33, T. 6S., R. 7E.; gully on south side of Crow Creek, W. of Crows Landing

Str. position: No precise record; "probably Joaquin formation"

Fossil: Baculites rex ANDERSON (holotype)

Age: Maestrichtian or Upper most Campanian (?)

Coll: J. G. TAFF, C. W. CRoss, \& G. D. HANNA, 6/6/1935

CAS. 28399A

Area: Robert Island Quad., San Joaquin Co., W. San Joaquin Valley

Loc.: Amerada Petrol. Corporat. Core, F. D. L. Well, No. 2, 450 feet S., 450 feet E., center of sec. 15, T. 2 S., R. $5 \mathrm{E}$

Str. position: "Top of Moreno"; black shale

Fossil: Diplomoceras (?) sp. (crushed)

Age: Uncertain

Coll:: Hanna \& Cross, Sept., 1935

CAS. 28442

Area: Briones Valley Quad., Contra Costa Co., Bay Area

Loc.: No indication of sec., T. \& R.; near the mouth of Briones Creek, 4 miles south of Brentwood 
Str. position: No record

Fossil: Baculites subcircularis ANDERSON [type locality] (resembling B. teres (Forbes) )

Age: Uncertain

Coll.: No record

CAS. 28542

Area: Panoche Quad. (1:125000), Fresno Co., W. San Joaquin Valley

Loc.: 800 feet S. of center of sec. 15, T. 14S., R. 11E.; Bottom of N-S running branch of Moreno Gulch, Panoche Hills

Str. position: No record; from T. Matsumoto's field observation, the locality is in the upper part of Upper Marlife formation of Panoche group

Fossils: Neophylloceras gargantcum (ANDERSon) (holotype), Pachydiscus buckhami USHER [= Parapachydiscus panochensis ANDERSON, 1958, holotype], Baculites cf. inornatus MEEK

Age: Campanian

Coll.: G. D. Hanna \& C. C. Church, Feb. 1936 (found by Donald C. Birch \& Max BIRK)

CAS. 29086

Area: Byron Quad., Contra Costa Co., Bay Area

Loc.: NW. 1/4, sec. 13, T. 1S., R. 2E.; E. of Marsh Creek, road toward Byron

Fossil: Baculites inornatus MEEK

Age: Upper Campanian

Coll.: B. L. ClaArK

CAS. 29102

Area: Volta Qoad. $(1: 24000)$, Merced Co., W. San Joaquin Valley

Loc.: Center of S. $1 / 2$ of sec. 26, T. 10S., R. 9E.; (close to UC. A-4684)

Str. position: "Garzas limestone"

Fossil: Tetragonites cf. popetensis $\mathrm{Y}$ ABE

Age: Campanian or Lower Maestrichtian

Coll.: Allan BeNNison

CAS. 29108

Area: Ortigalita Peak Quad., Merced Co., W. San Joaquin Valley

Loc.: Center of W. border of sec. 20, T. 11S., R. 10E.; south branch of Salt Creek

Str. position: No record of formational name; in calcareous pebbly sandstone

Fossils: Neophylloceras ramosum (MEEK) (?) [= Phylloceras pachecoense ANDERSON, 1958, holotype and other examples]

Age: Probably Senonian

Coll.: Allan BENnison (121)

CAS. 29109

Area: Ortigalita Peak Quad., Merced Co., W. San Joaquin Valley

Loc.: SE. $1 / 4$ of SE. $1 / 4$, sec. 18, T.11S., R.10E.; Salt Creek

Str. position: Pebbly calcareous sandstone

Fossils: Pachydiscus ef. ootacodensis (STocliczKa), Diplomoceras (?) sp.

Age: Lower Maestrichtian or highest Campanian

Coll.: Allan BeNNison

CAS. 29118

Area: Pacheco Pass Quad., Stanislaus Co., W. San Joaquin Valley

Loc.: Center of S. $1 / 2$ of sec. 33, T.8S., R.8E.; $1 / 2$ mile south of Mustang Creek 
Str. position: No reliable record; rock matrix is conglomeratic, calcareous sandstone

Fossils: Pachydiscus (s.s.) sp. indet., Glyptoxoceras (?) cf. subcompressum (ForBes) [=Diplomoceras mustangense ANDERSON, 1958 holo- and paratypes], Baculites columna Morton, Baculites sp. (same as B. sp. of Stephenson, 1941, pl. 76, figs. $5,6)$

Age: Maestrichtian (lower part)

Coll.: Allan BenNison

CAS. 29123

Area: Pacheco Pass Quad., Stanislaus Co., W. San Joaquin Valley

Loc.: E. of center of sec. 19, T.8S., R.8E. or 1800 feet W. and 2000 feet N. of SE. corner of the same section; a gully on south side of the first prominent hill near the entrance of the creek, S. branch of Garzas Creek

Str. position: Massive, gray to yellow calcareous mudstone in gray shale, which was referred to Moreno shale by BENNISON and to upper part of Panoche group by M. B. Payne

Fossils: Pachydiscus cf. egertoni (ForBes), Exiteloceras (?) diabloense (ANDERSON) [type locality], Nostoceras splendidum (SHUMARD) [ $=$ Turrilites excelsus ANDERSON, 1958, holotype], Solenoceras sp.

Age: Lower Maestrichtian or highest Campanian

Coll.: Allan BenNison

CAS. 29547

Area: Millville Quad. (Redding area), Shasta Co., NE. Sacramento Valley

Loc.: $\quad$ SW. $1 / 4$, sec. 4, T.32N., R.3W.; Frazier Corner, Shasta County

Str. position: Member II (?); in a light grey siltstone

Fossil: Subprionocyclus sp.

Age: Upper Turonian

Coll.: J. A. Taff, G. D. Hanna, \& C. M. Cross

CAS. 29585

Area: Pacheco Pass Quad., Merced Co., W. San Joaquin Valley

Loc.: Center of S. 1/2, sec. 24, T.10S., R.8E., BERILLES ranch

Str. position: A boulder in a conglomerate

Fossils: Subprionocyclus sp., Hyphantoceras sp.

Age: Turonian (derived fossils ?)

Coll.: No record

CAS. 29591

Area: Pacheco Pass Quad., Merced Co., W. San Joaquin Valley

Loc.: Sec. 12, T.9S., R. 8E.; Quinto Creek, from a gully $1 / 4$ mile north of the Quinto Creek, above the conglomerate that overlies the bed with Collignoniceras

Str. position: No formational name

Fossils: Subprionocyclus sp., Scalarites sp., Scaphites sp.

Age: Upper Turonian

Coll.: No record

CAS. 29592

Area: Pacheco Pass Quad., Merced Co., W. San Joaquin Valley

Loc.: Middle of S. line of SE. 1/4, sec. 1, T.9S., R.7E.; Quinto Creek

Str. position: No formational name; sandy shale

Fossils: Subprionocyclus sp., Scalarites sp. (fragment)

Age: Upper Turonian

Coll.: No record 
CAS. 29596

Area: Pacheco Pass Quad., Merced Co., W. San Joaquin Valley

Loc.: NW. $1 / 4$, NE. 1/4, sec. 7, T.9S., R.8E.; north side of Quinto Creek

Str. position: Shale unit, "not far above basal Panoche conglomerate (of ANDERSON)"; probably equivalent of the Lower Marlife formation of Panoche group in the correct sense

Fossil: Peroniceras quintoense AnDERson [type locality]

Age: Coniacian

Coll.: No record

CAS. 29598

Area: Pacheco Pass Quad., Merced Co., W. San Joaquin Valley

Loc.: Center of NE. 1/4, sec. 12, T.9S., R.7E.

Str. position: No formational name; greenish grey fine-sandy shale

Fossil: Collignoniceras sp.

Age: Middle Turonian

CAS. 29602

Area: Pacheco Pass Quad., Stanislaus Co., W. San Joaquin Valley

Loc.: Center W. (?) side NE. 1/4, sec. 19 (?), T.8S., R.8( ?) E., in gully

Str. position: No record; a black, compact, calcareous nodule

Fossils: Pachydiscus cf. subcompressus Matsumoto, Pseudophyllites (?) sp.

Age: Lower Maestrichtian or Upper Campanian

Coll.: Cross (?)

CAS. 29652

Area: Orestimba Quad., Stanislaus Co., W. San Joaquin Valley

Loc.: W. $1 / 2$ of SW. 1/4, sec. 15, T.6S., R.7E.

Str. position: No record

Fossils: Pachydiscus cf. subcompressus subcompressus Matsumoto, Pachydiscus subcompressus obsoletus MATSUMOTo

Age: Lower Maestrichtian

Coll.: Allan BENNison

CAS. 29653

Area: Pacheco Pass Quad., Stanislaus Co., W. San Joaquin Valley

Loc.: SE. $1 / 4$ of SE. $1 / 4$, sec. 13, T.8S., R.7E.; Oat Gulch of Garzas Creek

Str. position: No record

Fossil: Pachydiscus cf. subcompressus Matsumoto (crushed)

Age: Lower Maestrichtian or Upper Campanian

Coll.: Allan BENNison

CAS. 29656

Area: Ortigalita Peak Quad., Merced Co., W. San Joaquin Valley

Loc.: About 2500 feet N. of SE. corner of sec. 33, T.11S., R.10E.; a canyon 1 mile south of Ortigalita Creek

Str. position: No record of formational name; a coarse pebbly sandstone

Fossils: Neophylloceras hetonaiense Matsumoto (a variety with umbilical bullae), Anagaudryceras ef. mikobokense CoLlignon [=Lytoceras (Gaudryceras) aureum ANDERSon, 1958, holotype], Glyptoxoceras cf. largesulcatum (ForBes) [=Diplomoceras mercedense ANDERSON, holotype], Exiteloceras(?) ortigalitense (ANDERSON), 1958, holotype

Age: Probably Lower Maestrichtian

Coll.: Allan BeNNison 
CAS. 29664

Area: Orestimba Quad., Stanislaus Co., W. San Joaquin Valley

Loc.: NE. $1 / 4$, NE. $1 / 4$, sec. 30, T.5S., R.7E.; Puerto Creek

Str. position: No record; "Los Gatos stage” by ANDERSON's writing

Fossils: Pachydiscus cf. ootacodensis (Stoliczka) [=Parapachydiscus stanislausensis ANDERson, 1958, holotype], Didymoceras cf. hornbyense (Whiteaves) [=Didymoceras californicum ANDERSON, 1958, paratype], D. cf. vacouverense (GABB) [= ? Exiteloceras bennisoni ANDERSON, 1958, holotype]

Age: Campanian

Coll.: Allan BeNNison

CAS. 29666

Area: Orestimba Quad., Stanislaus Co., W. San Joaquin Valley

Loc.: Center of SW. 1/4, sec. 29, T.5S., R.7E.; a few fossiliferous boulder $1 / 2$ mile of Puerto Canyon

Str. position: "Above the Panoche-Moreno contact"; This is still in the upper part of Panoche group in M. B. PAYNE's map.

Fossil: Didymoceras vancouverense (GABB) [=Didymoceras fresnoense ANDERson, 1958, holotype]

Age: Upper Campanian or Lowest Maestrichtian (?)

Coll:: Allan Bennison

CAS. 29670

Area: Pacheco Pass Quad., Merced Co., W. San Joaquin Valley

Loc.: Near line of sec. NE. $1 / 4$, of NW. $1 / 4$ of sec. 32, T.8S., R.8E.; north of Mustang Creek

Str. position: Upper part of Panoche group, "550 feet below the Moreno"

Fossils: Baculites sp., Pachydiscus sp., Inoceramus sp.

Age: Uncertain

Coll.: Allan BenNison

CAS. 29671

Area: Orestimba Quad., Stanislaus Co., W. San Joaquin Valley

Loc.: On Salado Creek in center of S. 1/2, sec. 16, T.6S., R.7E.

Str. position: "Pachydiscus zone" of "Panoche group", 500 feet below "Moreno"

Fossil: Pachydiscus ootacodensis (SToLICZKa)

Age: Campanian or Lower Maestrichtian

Coll.: Allan BENNison

CAS. 29678

Area: Pacheco Pass Quad., Stanislaus Co., W. San Joaquin Valley

Loc.: Middle of E. border of sec. 23, T.8S., R.7E.; Garzas Creek

Str. position: "Upper Panoche"

Fossils: Inoceramus subundatus MeEK [="Inoc. whitneyi GABB"], Baculites sp.

Age: Campanian

Coll.: A. BenNison

CAS. 30551

Area: Ortigalita Peak Quad., Merced Co., W. San Joaquin Valley

Loc.: 2300 feet N., 950 feet E. of SW. corner, SW. 1/4, sec. 28, T.11S., R.10E.

Str. position: Calcareous sandstone ("Moreno" but probably not)

Fossil: Diplomoceras sp. (compressed whorl)

Age: Upper Senonian

Coll.: J. J. BRYAN 
CAS. 31097

Area: Ono Quad., Tehama Co., NW. Sacramento Valley

Loc.: $\quad 4.6$ miles west of Rosewood, Dry Creek

Str. position: 1/3 mile east of "basal conglomerate of Upper Cretaceous"

Fossils: Desmoceras (Pseudouhligella) poronaicum YABE, Mariella sp., Sciponoceras kossmati (NowAK) [=Cyrtochilus stylus ANDERSON, holotype]

Age: Cenomanian and Lower Turonian

Coll.: Bennison, McCoy, \& F. M. ANDERson

CAS. 31101

Area: Ono Quad., Tehama Co., NW. Sacramento Valley

Loc.: No record of sec., T. \& R.; 3.3 miles from Rosewood, 16.2 miles from Beegum, Dry Creek

Str. position: No record; shale unit

Fossils: Subprionocyclus sp. [="Prionotropis sp."], Mesopuzosia cf. indopacifica (Kossmat) [="Holcodiscoides" sp.]

Age: Upper Turonian

Coll.: F. M. ANDERson (?)

CAS. 31102

Area: Ono Quad., Tehama Co., NW. Sacramento Valley

Loc.: SE. $1 / 4$, sec. 17, T.28N., R.6W; 1 mile northwest of Rosewood, on Dry Creek

Str. position: No record

Fossil: Pachydesmoceras pachydiscoide Матsuмото [=Pachydiscus rosewoodensis ANDERSON, 1958, holotype]

Age: Turonian

Coll.: No record

CAS. 31115

Area: Morgan Valley Quad., Colusa Co., W. Sacramento Valley

Loc.: No record of sec., T. \& R.; SW. branch of Cortina Creek, west of Sand Creek

Str. position: No record; Funks shale (?)

Fossil: Hyphantoceras cf. venustum (YABE) [=Hyphantoceras laquem ANDERSON, 1958, holotype]

Age: Lower Senonian

Coll.: Allan BenNison

CAS. 31131

Area: Pacheco Pass Quad., Stanislaus Co., W. San Joaquin Valley

Loc.: NE. 1/4, SW. 1/4, sec. 29, T.8S., R.7E.; on upper branch of Garzas Creek

Str. position: No record; dark colored, coarse-grained sandstone

Fossils: Kanabiceras septemseriatum (CRAGIN) [= Lyelliceras stanislausense ANDERson, holotype], Sciponoceras kossmati (NowAK) [=Cyrtochilus stylus ANDERSON, paratype]

Age: Lower Turonian

Coll.: ANDERson, McCoy, \& Bennison

CAS. 31208

Area: Rumsey Quad., Yolo Co., W. Sacramento Valley

Loc.: W. half, sec. 23, T.12N., R.3W.; east border of Niger Heaven basin, $1 / 4$ mile NE. of Lee Bow Wells

Str. position: Probably Forbes formation

Fossil: Canadoceras cf. newberryanum (MEEK) [=Canadoceras celeste ANDERSON, 1958, holotype]

Coll.: F. M. ANDERSON 
CAS. 31209

Area: Morgan Valley Quad., Yolo Co., W. Sacramento Valley

Loc.: 2 miles above Rumsey, Cache Creek

Str. position: Probably Funks shale (greenish grey shale)

Fossils: Peroniceras sp., Gaudryceras sp., Scalarites sp., Scaphites sp., Otoscaphites sp.

Age: Coniacian

Coll.: F. M. ANDERSON

CAS. 31229

Area: Southern part of San Benito Co., W. San Joaquin Valley

Loc.: About 9 miles northwest of New Idria Mines in the McCoy Creek drainage basin Str. position: No record

Fossil: Mortoniceras sp. aff. M. adkinsi Young

Age: Upper Albian

Coll.: D. L. RoHrbaCK, 1922

CAS. $31230 *$

Area: Millville Quad. (Redding area), Shasta Co., NE. Sacramento

Loc.: East of CaLKins ranch house on Little Cow Creek

Str. position: Member II of PoPENOE

Fossils: Romaniceras deverioide (GROSSOUVRE) [= Mantelliceras conquistador ANDERsoN, 1958, holotype and another example]

Age: Middle Turonian

Coll.: A. L. ROHRBACK

CAS. 31231

Area: Millville Quad. (Redding area), Shasta Co., NE. Sacramento Valley

Loc.: S. $1 / 2$, sec. 4, T.32N., R.3W.; Swede Creek (French Creek)

Str. position: Member III or IV according to POPENOE, but very doubtful (The species is same as that of Member II.)

Fossil: Romaniceras deverioide (GROSSOUvRE) [=Romaniceras hesperium ANDERSON, 1958, holotype]

Age: Turonian (probably middle part)

Coll.: W. P. POPENOE

CAS. 31245

Area: Tesla Quad., Alameda Co., Bay Area

Loc.: SE. $1 / 4$ of NW. $1 / 4$, sec. 13, T.4S., R.2E.; Arroyo del Valle, in a creek south of Hetch-Hetchy Tunnel

Fossils: Neophylloceras sp., Pachydiscid indet., Metaplacenticeras sp., Gaudryceras sp., Baculites inornatus MEEK, Baculites sp. aff. B. anceps LAMARCK

Age: Upper Campanian

Coll.: S. McCoY

CAS. 31288

Area: Morgan Valley Quad., Yolo Co., W. Sacramento Valley

Loc.: No record of sec., T. \& R.; head of west branch of Cortina Creek

Str. position: Funks shale (?)

Fossils: Prionocycloceras crenulatum (ANDERSON), Baculites cf. schencki Matsumoto, Inoceramus sp. (large)

Age: Coniacian

Coll.: F. M. ANDERSON 
CAS. 31289

Area: Rumsey Quad., Yolo Co., W. Sacramento Valley

Loc.: No record of sec., T. \& R.; near concrete bridge on Cache Creek, 3 miles northwest of Rumsey

Str. position: No record; compact, concretion in Funks formation (?)

Fossil: Baculites capensis Woods

Age: Lower Senonian

Coll.: No record

CAS. 31310

Area: Panoche Quad., Fresno Co., W. San Joaquin Valley

Loc.: Near center of sec. 17, T.15S., R.12E.

Str. position: Moreno shale

Fossil: Neophylloceras hetonaiense Matsumoto (a variety with umbilical bullae)

Age: Maestrichtian

Coll.: C. C. Church \& J. J. Bryon, 1940

CAS. 31327

Area: Rumsey Quad., Yolo Co., W. Sacramento Valley

Loc.: Middle of E. $1 / 2$ of SW. $1 / 4$, sec. 23, T.12N., R.3W.; Buckeye Creek

Str. position: Probably Forbes formation; in limy concretions

Fossils: Baculites cf. inornatus MEEK, cf. Anapachydiscus californicus (YABE) (fragment)

Age: Campanian

Coll.: No record

CAS. 31364

Area: Rumsey Quad., Yolo Co., W. Sacramento Valley

Loc.: No record of sec., T. \& R.; Petroleum Creek

Str. position: No formational name; in a calcareous conglomerate containing Glycymeris, etc.

Fossils: Desmophyllites sp., Canadoceras (?) sp., Baculites cf. inornatus MEEK, Pseudoxybeloceras (?) petrolense (ANDERson) [type locality]

Age: Campanian (?)

Coll.: Allan BenNison

CAS. 31366

Area: Kern Co., SW. San Joaquin Valley

Loc.: Napoleon Springs, Cedar Canyon

Str. position: "In shale just below a black conglomerate" (silty calcareous nodule)

Fossils: Desmophyllites diphylloides (FoRBEs) [= "D. selwynianum WHITEAVES"],

Baculites cf. occidentalis MEEK (immature)

Age: Upper Campanian

Coll.: No record

CAS. 31368

Area: Kern Co., SW. San Joaquin Valley

Loc.: "Cedar Canyon", NW. part of Kern Co.

Str.position: No record

Fossils: Nostoceras sp. [="Turrilites sp."], Baculites cf. occidentalis MeEK

Age: Upper Campanian (?)

Coll.: G. D. HANNA

CAS. $31401[=31567]$ 
Area: Cholame Quad. (1:125000), Kern Co., SW. San Joaquin Valley

Loc.: Sec. 14, T.28S., R.19 (18?) E.; the second patch of the Cretaceous shale hills, back from Antelope valley, on the road up Bitterwater Canyon

Str. position: No record; a sandy calcareous nodule

Fossils: Baculites rex ANDERSON* [= "Baculites inornatus MEEK" in the label]

Age: Lower Maestrichtian or highest Campanian (?)

Coll.: W. Stanley KNouse, 1941

CAS. 31402

Area: Simmler Quad., Kern Co., SW. San Joaquin Valley

Loc.: Center of N. half of Sec. 22, T.28S., R.19E.; Media Agua Creek

Str. position: "Flot found in Creek bottom, but came from the upper 0000 (spel ?) few hundred feet of the Cretaceous exposed in that area"

Fossils: Baculites rex ANDERson, Inoceramus sp. (smoothish and large)

Age: Lower Maestrichtian or highest Campanian (?)

Coll.: G. D. Hanna, J. S. Bryan, \& J. Hewitt, April 1941

CAS. 31593 [=CAS. 2361]

Area: Joaquin Rock Quad., Fresno Co., W. San Joaquin Valley

Loc.: 1620 feet W., 1400 feet S. of NE. corner of sec. 7, T.19S., R.15E.; Joaquin Ridge

Str. position: Ragged Valley shale (calcareous nodules in a siltstone)

Fossils: Damesites hetonaiensis fresnoensis (ANDERSON), Pachydiscus subcompressus obsoletus Matsumoto [="Joaquinites fascicostatus ANDERSON" holotype], Hauericeras sp., Tetragonites popetensis YABE; Didymoceras vancouverense (GABB) (hooked part) or hornbyense (WhiteAves) (coiled part), Solenoceras sp., Baculites lomaensis ANDERSON, Baculites rex ANDERSON

Age: Lower Maestrichtian or highest Campanian

Coll.: C. C. Church, G. D. Hanna, \& R. L. Hewitt

CAS. 33551

Area: Ono Quad., Shasta Co., NW. Sacramento Valley

Loc.: No record of sec., T. \& R.; conglomerate bed below STEwARTS ford, North Fork of Cottonwood Creek

Str. position: No record

Fossils: Desmoceras (Pseudouhligella) cf. dawsoni Whiteaves, Lechites sp.

Age: Upper Albian (?)

Coll.: No record

CAS. 33667

Area: Siskiyou Co., N. California

Loc.: North side of Rancheria Creek, near Hornbrook

Str. position: No formational name; silty fine-sandstone, weathered brown-greenish

Fossil: Subprionocyclus cf. neptuni (GeINITZ)

Age: Upper Turonian

Coll.: No record

CAS. 33693

Area: Mt. Diablo Quad., Bay Area

Loc.: S. $1 / 2$ of NE. $1 / 4$, sec. 15, T.1N., R.1E.

Str. position: "In the first shale belt"

Fossil: Baculites cf. occidentalis MEEK

Age: Upper Campanian

Coll.: S. McCoY 
CAS. 33696

Area: Millville Quad. (Redding area), Shasta Co., NE. Sacramento Valley

Loc.: $\quad 3 / 4$ mile north of highway on Oak Run Road

Str. position: Presumably Member IV of PopenoE

Fossils: Baculites cf. capensis Woods; Hauericeras (Gardeniceras) sp. [="Placenticeras sp.']; Inoceramus sp. (a large, but crushed specimen)

Age: Lower Senonian

Coll.: No record

CAS. 33699

Area: Millville Quad. (Redding area), Shasta Co., NE. Sacramento Valley

Loc.: Center of sec. 16, T.32N., R.2W ; near HATHways house, on Oak Run

Str. position: Member IV (?) (in grey silty shale)

Fossil: Hyphantoceras sp.

Age: Lower Senonian

Coll.: No record

CAS. 33700

Area: Millville Quad. (Redding area), Shasta Co., NE. Sacramento Valley

Loc.: Near the highest bed of fossils on Swede Creek, 2 miles north of HATHWAY ranch

Str. position: Member IV (?)

Fossils: Baculites capensis Woods (a number of specimens showing a certain extent of variation)

Age: Lower Senonian

Coll.: No record

CAS. 33702

Area: Lost Hills Quad. (1:125000), Kern Co., SW. San Joaquin Valley

Loc. Cedar Canyon, $1 \frac{1}{2}$ miles SE. of mouth of Cedar Canyon, McDonald ranch

Str.position: No record

Fossils: Baculites sp., Bostrychoceras sp. (fragment)

Age: Uncertain

Coll.: No record

CAS. 33703

Area: Ono Quad., Tehama Co., NW. Sacramento Valley

Loc.: Dry Creek, 0.3 mile upstream from "Oregoniceras" locality

Str. position: No precise record

Fossils: Puzosia cf. intermedia (Kossmat) (much deformed) [="Parapuzosia" sp.], cf. Lewesiceras sp., cf. Scalarites sp. (large fragment)

Age: Turonian

Coll.: No record

CAS. 33704

Area: Pacheco Pass Quad., Merced Co., W. San Joaquin Valley

Loc.: On section line boundary, sec. 14 and 15, just above middle, T.9S., R.8E.; Quinto Creek, on How ARD ranch, near house

Fossils: Inoceramus subundatus MEEK, Baculites cf. inornatus MEEK (?)

Age: Campanian

Coll.: No record

CAS. 33705 (Two faunas mixed)

Area: W. San Joaquin Valley

A. Hospital Canyon "Panoche group" 
Baculites occidentalis MEEK in a silty calcareous nodule; Upper Campanian

B. Hospital Canyon (?)

Puzosigella sp., Phyllopachyceras sp., "Belemnoteuthis" sp. in calcareous finesandstone

Lower Cretaceous (Albian)

CAS. 33706

Area: Tesla Quad., Alameda Co., Bay Area

Loc.: Arroyo del Valle, 1 mile south of Aquaduct

Str. position: "Basal bed of Chico" (calcareous conglomerate)

Fossils: Puzosia ?, Mesopuzosia ? sp., Sciponoceras kossmati (NowAK)* [="Baculites cf. vagina FORBES" by ANDERSON]

Age: Lower Turonian

Coll.: A. S. HuCY

CAS. 33709

Area: Placer Co., E. Sacramento Valley

Loc.: Rock Corral (Texas Flat), 3 miles NW. of Folsom

Str. position: No record; calcareous fine-sandstone, full of mollusca

Fossil: Baculites inornatus MEEK*

Age: Upper Campanian

Coll: No record

CAS. 33717

Area: Rumsey Quad., Colusa Co., W. Sacramento Valley

Loc.: South side, sec. 34, T.13N., R.3W.; south of Blue Ridge Well, Salt Creek

Str. position: Probably Forbes shale (basal part)

Fossil: Patagiosites arbucklensis (ANDERSON) [=Eupachydiscus arbucklensis ANDERsoN]

Age: Campanian

Coll.: H. L. DobBins

CAS. $33719[=$ ? 31131]

Area: Pacheco Pass Quad., Stanislaus Co., W. San Joaquin Valley

Loc.: NE. $1 / 4$ of SW. 1/4, sec. 29, T.8S., R.7E.; in little branch SW. of Garzas Creek Str. position: "Basal Pioneer group", calcareous very coarse sandstone

Fossils: Kanabiceras cf. septemseriatum (CRAGIN); Sciponoceras cf. kossmati (NowaK), Inoceramus cf. labiatus Schlotheim

Age: Lower Turonian

Coll.: No record

CAS. 33721

Area: Millville Quad. (Redding area), Shasta Co., NE. Sacramento Valley

Loc.: NE. $1 / 4$, sec. 32 , T.32N., R.1W.; south Cow Creek

Str. position: Probably Member V

Fossil: Inoceramus cf. ezoensis YoкоYамA

Age: Santonian

Coll.: No record

CAS. 33722

Area: Orestimba Quad., Stanislaus Co., W. San Joaquin Valley

Loc.: Cow Creek, $1 / 4$ mile above well, S. branch following old road to south

Fossil: Baculites cf. occidentalis MEEK

Age: Campanian

Coll: : G. D. HANNA 
CAS. 33725

Area: Fruto Quad., Glenn Co., W. Sacramento Valley

Loc. \& Str. position: No record of sec., T. \& R., but probably in SW. $1 / 4$ of sec. 32, T.20N., R.5W.; "5 miles S. of Fruto, in Willows Creek (Clark Valley), 1/2 mile N. of conglomerate near the base of the Chico

Fossils: Desmoceras (Pseudouhligella) japonicum YABE, Puzosia sp., Catycoceras cf. spinosum (Kossmat)*

Age: Cenomanian (probably middle part)

Coll.: No record

CAS. 33726

Area: Fruto Quad., Glenn Co., W. Sacramento Valley

Loc.: No record of sec., T. \& R., but presumably SE. 1/4, SE. 1/4, sec. 29, T.20N., R.5W.; 3 miles south of Fruto, on Willows Creek (Clark Valley)

Str. position: No record; probably a shale unit immediately below the equivalent of Venado sandstone

Fossil: Inoceramus labiatus SchlotheIM [=Inoceramus glennensis ANDERSON, 1958, holotype and paratype]

Age: Lower Turonian

Coll.: No record

CAS. 33727

Area: Millville Quad. (Redding area), Shasta Co., NE. Sacramento Valley

Loc.: No record of sec., T. \& R.; "South fork of Cow Creek, 1 mile above Power Plant"

Str. position: ANDERSON referred it to "Yolo formation"; the locality should be in the upper part of Member $\mathrm{V}$ of PoPENOE.

Fossils: A (in shaly matrix) Inoceramus cf. ezoensis Yokoyama, Baculites sp. indet. (too much crushed); B (in sandy matrix) Inoceramus cf. cordiformis SowERBY, Pseudoschloenbachia sp. (fragment)

Age: Probably Santonian

Coll: No record

CAS. 33728

Area: Tesla Quad., Alameda Co., Bay Area

Loc.: E. center of sec. 27, T.2S., R.3E.; about 2 miles SE. of Altamonta (Loc. XIII of HUEY, 1948)

Str. position: No record

Fossil: Pachydiscus (Anapachydiscus ?) sp. (crushed) [listed as Canadoceras, HuEY, 1948, p. 29]

Age: Campanian (?)

Coll.: A. S. HUEY

CAS. 33729

Area: Oakland East Quad., Bay Area

Loc.: SE. 1/2, sec. 7, T.1S., R.3W.; Berkeley Hills

Str. position: No record of formational name

Fossil: Turrilites costatus LAMARCK

Age: Cenomanian

Coll.: B. L. CLARK (?)

CAS. 33730

Area: Ono Quad., Shasta-Tehama Co., NW. Sacramento Valley

Loc.: No record of sec., T. \& R.; middle fork of Cottonwood Creek near HickMoN's 
place

Str. position: No precise record; greenish grey shale

Fossil: Collignoniceras sp. juvenile cf. woollgari (MANTELL)

Age: Turonian

Coll.: No record

CAS. 34405

Area: Ono Quad., Shasta Co., NW. Sacramento Valley

Loc.: No record of sec., T. \& R.; Hayes Gulch, 2 miles northwest of Gas Point

Fossil: Sciponoceras baculoide (MANTELL)

Age: Cenomanian

Coll.: No record

CAS. 34408

Area: Ono Quad., Shasta-Tehama Co., NW. Sacramento Valley

Loc.: Near Hickman ranch, Middle Fork of Cottonwood Creek, Shasta Co.

Str. position: No precise record; nodule in dark grey, fine-sandy siltstone

Fossil: Collignoniceras sp. immature [="Prionotropis bakeri ANDERSON"]

Age: Turonian

Coll.: No record

CAS. No number

Area: Hornbrook Quad., Siskiyou Co., N. California

Loc.: RICHARDSON ranch, 4 miles N. of Montague

Str.position: No precise record

Fossils: Kossmaticeras (?) klamathone (ANDERson) [type locality], Prionocycloceras crenulatum (ANDERSON)

Age: Coniacian

Coll.: No record

CAS. No number

Area: Redding Quad., Shasta Co., NE. Sacramento Valley

Loc.: No record of sec. T. \& R.; "1 mile north of Redding on highway"

Str. position: Almost certainly Member II (personal communication from PoPENoE)

Fossil: Tragodesmoceras averilli ANDERSON [type locality]

Age: Turonian (?)

Coll.: No record

CAS. No number

Area: Marysville Buttes and Vicinity Quad., Sutter Co., Sacramento Valley

Loc.: SW. $1 / 4$ of NE. $1 / 4$, sec. 35, T.16N., R.1E.; slightly more than a mile south of South Butte on each side of gully

Str. position: No formational name; "Grey pebbly calcareous sandstone lenses in dull brown shelly sandstone"

Fossil: Baculites cf. inornatus MeEK

Age: Campanian

Coll.: No record

CAS. No number

Area: Redding Quad., Shasta Co., NW. Sacramento Valley

Loc.: SE. $1 / 4$ of SW. $1 / 4$ of sec. 30, T.31N., R.5W., Jackass Flat

Str.position: No record

Fossil: Hulenites jimboi (ANDERSON) [type locality]

Age: Albian

Coll:: No record 
CAS. No number

Area: Pacheco Pass Quad., Stanislaus Co., W. San Joaquin Valley

Loc.: Center of S. $1 / 2$ of SE. $1 / 4$ of sec. 3, T.9S., R.7E.; Quito Creek

Str. position: In conglomerate unit

Fossil: Turrilites costatus LAMARCK [=Turrilites pachecoensis ANDERSON, holotype]

Age: Cenomanian

Coll.: No record

CIT. 54

Area: Los Angeles Co., Santa Monica Mts., S. California

Loc.: "Massive sandstone in a quarry in Santa Ynez Canyon, 1.75 miles N. of Ocean Boulevard

Str. position: Member IV of H. D. B. WILSON-that is, next to highest member of Cretaceous section in Santa Monica Mountains (See Popenoe, 1942, p. 176)

Fossil: Metaplacenticeras pacificum (Sмгтн)

Age: Upper Campanian

Coll.: H. W. HOOTS \& W. P. WOODRING, 1927

CIT. 79

Area: Corona Quad., Orange Co., Santa Ana Mts., S. California

Loc.: West of spring in the gully back of HoLZ ranch, just below Ladd Canyon, Silverado Canyon

Str. position: Holz-Baker Canyon transition

Fossils: Subprionocyclus cf. neptuni (GEINITZ), Sciponoceras aff. S. bohemicum (FRITSCH)*

Age: Upper Turonian

Coll.: B. N. MOORE, 1928

CIT. 83

Area: Corona Quad., Orange Co., Santa Ana Mts., S. California

Loc.: 400 feet S. of NE. corner, sec. 19, T.5S., R.7W.; section line fence gate on old road, $1 / 4$ mile west of Schulz ranch, south side of Williams Canyon

Str. position: Calcareous sandstone at top of Holz shale

Fossils: Pseudoxybeloceras (?) lineatum (GABB), Baculites inornatus MEEK

Age: Campanian

Coll.: B. N. MOORE, 1926

CIT. 85

Area: Corona Quad., Orange Co., Santa Ana Mts., S. California

Loc.: $1 / 2$ mile SSE. of NE. corner of sec. 13, T.6S., R.7E.; on ridge near SE. corner of field, "Trabuco Creek"

Str. position: Uncertain; in arkosic sandstone

Fossil: Bostrychoceras sanctaeanae ANDERSON

Age: Uncertain

Coll.: B. N. MOORE, 1926

CIT. 96

Area: Corona Quad., Orange Co., Santa Ana Mts., S. California

Loc. and Str. position: No precise record; concretions in shale on spur south of loc. 95, about 100 feet above creek

Fossil: Pachydiscus sp. juvenile (cf. neevesi Whiteaves)

Age: Campanian (?)

Coll.: B. N. MOORE 
CIT. 99

Area: Corona Quad., Orange Co., Santa Ana Mts., S. California

Loc.: South side of Silverado Canyon about 400 feet above stream in gully just west of a large canyon coming in from south about 1.5 miles east of Ladd Canyon

Str. position: Basal part of Holz shale

Fossils: Baculites sp. indet. or Sciponoceras (poor preservation)

Age: Uncertain (highest Turonian or Coniacian ?)

Coll.: B. N. MOORE, 1928

CIT. 623

Area: Pt. Conception Quad., Santa Barbara Co., Santa Ynez Range, S. California

Loc.: West of main road and south of crest, 5.84 miles $\mathrm{N} 27^{\circ} \mathrm{E}$ from BM at Conception

Str.position: No precise record

Fossil: Menuites sp.

Age: Senonian or Maestrichtian

Coll.: J. DorRANCE, Oct. 1929

CIT. 974

Area: El Toro (7.5 minute) Quad., Orange Co., Santa Ana Mts., S. California

Loc.: 6200 feet $\mathrm{S} .40^{\circ} \mathrm{E}$. of NW. corner, sec. 29, T.5S., R.7W.; southwest slope of ridge forming Aliso Creek-Santiago Creek divide

Str. position: Pleasants sandstone

Fossil: Metaplacenticeras pacificum (SмIтH)

Age: Upper Campanian

Coll.: W. P. Popenoe, 1/14/1933

CIT. 975

Area: El Toro (7.5 minute) Quad., Orange Co., Santa Ana Mts., S. California

Loc.: 300 feet N.50 ${ }^{\circ}$ W. of CIT. 974

Str.position: Pleasants sandstone

Fossil: Metaplacenticeras pacificum SMITH

Coll.: W. P. POPENOE

CIT. 976

Area: Corona Quad., Orange Co., Santa Ana Mts., S. California

Loc.: NW. $1 / 4$, NE. $1 / 4$, sec. 19 , T.5S., R.7W.; crest of first E-W spur south of Williams Canyon

Str. position: Pleasants sandstone

Fossils: Baculites sp. indet. (cf. B. rectus Marshall or $B$. bailyi Woods; not $B$. chicoensis nor B. inornatus)

Age: Uncertain from this single specimen, although Pleasants sandstone is Upper Campanian from other species

Coll.: W. P. Popenoe

CIT. 978,979

Area: Corona Quad., Orange Co., Santa Ana Mts., S. California

Loc.: About NE. corner of sec. 33, T.5S., R.7W.; NE. slope and near crest of bluff overlooking Santiago Canyon, approximately 1.5 miles SE. of the dam just above mouth of Harding Canyon: (P9-33; P10-33)

Str. position: Upper part of Baker Canyon sandstone member in Section A of PoPenoe, 1942; 978 is 150 feet above the base of the member; 979 is about 10 feet lower in section.

Fossils: Subprionocyclus cf. neptuni (GeINITZ), Sciponoceras aff. S. bohemicum (FRITSCH) 
Age: Upper Turonian

Coll.: W. P. Popenoe, 4/14/1933

CIT. 1005

Area: Millville Quad. (Redding area), Shasta Co., NE. Sacramento Valley

Loc.: Approximately SE. corner of NW. 1/4, sec. 33, T.32N., R.2W.; near crest of south slope of divide between Basin Hollow and Clover Creek: (P27-31)

Str. position: Member V (lower part)

Fossils: Baculites boulei CoLlignon, Inoceramus aff. I. ezoensis YokoYama (transitional from a flattened variety of $I$. inconstans Woods), Inoceramus naumanni YoKOYAMA

Age: Lower Senonian (probably Lower Santonian)

Coll.: W. P. Popenoe \& D. Scharf, 4/8/1931

CIT. 1006

Area: Millville Quad. (Redding area), Shasta Co., NE. Sacramento Valley

Loc.: Near NE. corner of NW. 1/4 (probably less than 400 feet south of sec. line), sec. 33, T.32N., R.2W.; near crest of north slope of divide between Basin Hollow and Clover Creeks: (P28-31)

Str.position: Member V (lower part)

Fossils: Baculites boulei Collignon*, Baculites kirki Matsumoto* (abundant), Inoceramus cf. cordiformis SowERBY

Age: Lower Senonian (probably Lower Santonian)

Coll.: W. P. Popenoe \& D. Scharf, 8/8/1931

CIT. 1007

Area: Millville Quad. (Redding area), Shasta Co., NE. Sacramento Valley

Loc.: Approximately $1 / 4$ mile S. $26^{\circ}$ E. of NW. corner of sec. 16, T.32N., R.2W.; hard limy sandstones outcropping on lower slope of hills north of Oak Run, and about 0.4 mile straight north of Hathaway BRos ranch-house

Str. position: Member IV

Fossils: Baculites boulei CoLLIGNoN* (including a variety with a relatively large node), Peroniceras (?) sp. juvenile*

Age: Lower Senonian

Coll.: $\quad$ W. P. Popenoe \& D. Scharf, 4/9/1931

CIT. 1008

Area: Millville Quad. (Redding area), Shasta Co., NE. Sacramento Valley

Loc.: NE. $1 / 4$, SE. $1 / 4$, sec. 32 , T.32N., R.2W.; southwest end of ridge forming divide between Basin Hollow and Clover Creeks, sandstone slabs outcropping at the head of small SW. flowing ravine and overlying massive cliff-forming conglomerate outcropping on north face of ridge: (P30-31)

Str. position: Member V (lower part)

Fossils: Baculites boulei CoLligNoN* (abundant), Baculites cf. schencki MATSUMOTO* (a few specimens)

Age: Lower Senonian

Coll.: W. P. Popenoe \& D. Scharf, 4/11/1931

CIT. 1010

Area: Millville Quad. (Redding area), Shasta Co., NE. Sacramento Valley

Loc.: SW. corner of SE. $1 / 4$, sec. 34, T33N., R. 3W.; fossiliferous concretions in shales, left bank of Salt Creek about $1 / 4$ mile N. of first prominent east-west turn, north of Alturas-Redding highway: (P32-31)

Str. position: Member II (base) or Member I (top) 
Fossils: Scaphites roguensis ANDERson, Otoscaphites puerculus (JIMBo) [=Scaphites inermis (ANDERSON)]

Age: Turonian [In Japan the species ranges through Turonian and Coniacian.]

Coll.: W. P. Popenoe \& D. Scharf

CIT. 1014

Area: Paradise Quad., Butte Co., E. Sacramento Valley

Loc.: NE. 1/4, sec. 1, T.23N., R.2E.; concretionary boulders in Cretaceous sandstones, right bank of Chico Creek, about 1 mile upstream from a little bridge across the creek (below MickeY's house) : (P35-31)

Str. position: Chico formation (s.s.) (basal part)

Fossil: Baculites schencki Matsumoto

Age: Lower Senonian

Coll.: W. P. Popenoe \& D. Scharf, 8/16/1931

CIT. 1016

Area: Paradise Quad., Butte Co., E. Sacramento Valley

Loc.: No record of sec., T. \& R., but probably in SE. 1/4, sec. 1, T.23N., R.2E.; "fossiliferous concretionary beds outcropping about halfway up the slope of the west bank of Big Chico Creek, in the first ravine flowing into Chico Creek, north of bridge below MickeY's house. About 2 miles N. $35^{\circ} \mathrm{W}$. of 14-mile house"

Str. position: Chico formation (s.s.) (relatively lower part)

Fossils: Hyphantoceras cf. venustum (YABE), Scalarites or Ryugasella or Polyptychoceras indet. (fragments)

Age: Lower Senonian

Coll.: W. P. Popenoe \& D. Scharf, 8/16/1931

CIT. 1017

Area: Paradise Quad., Butte Co., E. Sacramento Valley

Loc.: $\quad$ N. $1 / 2$ or SE. $1 / 4$ of sec. 1, T.23N., R.2E.; sandstone layer outcropping about 100 feet below lava-Cretaceous contact, on hill side, N. and a little E. of MICKEY's house, Chico Creek: (P28-31)

Str. position: Chico formation (s.s.) (relatively lower, but not basal, part)

Fossils: Hauericeras (Gardeniceras) angustum YABE [=H. mickeyi ANDERSON], Inoceramus cf. ezoensis YoKoYAMA

Age: Probably Santonian

Coll.: W. P. Popenoe \& D. Scharf, 8/18/1931

CIT. 1032

Area: Millville Quad. (Redding area), Shasta Co., NE. Sacramento Valley

Loc.: Shale exposed on left bank of Dry Creek, to the east of road, 1.3 miles north of Frazier Corners: (P129-33)

St. position: Member II

Fossil: Hyphantoceras sp.

Age: Turonian (for Member II)

Coll.: W. P. Popenoe \& W. A. Findlay, 8/30/1933

CIT. 1034

Area: Millville Quad. (Redding area), Shasta Co., NE. Sacramento Valley

Loc.: 0.4 mile $\mathrm{N}$. of HATHAWAY house on Oak Run road. The house is on south side of a road, 6.5 miles NE. from juncture of Oak Run and Millville highways

Str. position: Member IV

Fossils: Damesites damesi intermedius MATSUMOTo*, Peroniceras shastense ANDERSON, Prionocycloceras californicum Anderson, Baculites schencki MATSUmoto* [type 
locality]

Age: Coniacian

Coll.: W. P. POPENOE \& D. SCharf, 4/8/1931

CIT. 1040

Area: Paradise Quad., Butte Co., Chico Area, E. Sacramento Valley

Loc.: 200 feet N. and E. of SW. corner, sec. 8, T.22N., R.3E.; limestone beds outcropping along right bank of Butte Creek just under Tertiary gravels, 3.8 miles upstream from covered bridge on Paradise Road, over Butte Creek, and 10.2 miles along Chico-Centerville road from where road leaves U. S. highway 99E: (P37-33)

Str. position: Chico formation (s.s.)

Fossil: Baculites chicoensis TrASK

Age: Campanian

Coll.: W. P. Popenoe \& W. A. Findlay, 9/3/1933

CIT. 1042

Area: Yreka Quad., Siskiyou Co., N. California

Loc.: Left bank of Rancheria Gulch, 1.5 miles west of Henley-Planetable Survey Station S-131: (P39-33)

Str. position: "Sandstone near the base of Upper Cretaceous section in the Gulch"

Fossil: Subprionocyclus neptuni (GEINITZ) * [= "Oregoniceras" siskiyouense (ANDERSON)]

Age: Upper Turonian

Coll.: W. P. Popenoe \& W. A. Findlay, 9/9/1933

CIT. 1044

Area: Yreka Quad., Siskiyou Co., N. California

Loc.: 1435 feet W., 560 S., of NE. corner, sec. 30, T.47N., R.6W.; right bank of Rancheria Gulch just over hill north from ScHolz ranch house, 1.5 miles west of Henley-Planetable Station S-139: (P40-33)

Str. position: No record, probably same CIT. 1042

Fossil: Subprionocyclus cf. neptuni (GEINITZ)

Age: Upper Turonian

Coll.: W. P. Popenoe \& W. A. Findlay, 9/8/1933

CIT. 1053

Area: El Toro Quad., Orange Co., Santa Ana Mts., S. California

Loc.: 3000 feet E. of NW. corner, sec. 29, T.5S., R.7W.; first prominent NE.-SW. spur north of Santiago Creek near its juncture with Harding Creek, about 3000 feet straight $\mathrm{W}$. of the dam in Harding Creek

Str. position: Turritella chicoensis bed of the upper part of $\mathrm{Holz}$ shale member

Fossil: Canadoceras cf. yokoyamai (JiMBo) [ $\doteqdot$ C. multisulcatum (WhITEAVES)]

Age: Campanian

Coll.: W. P. Popenoe, 4/9/1934

CIT. 1062

Area: Black Star Canyon Quad., Orange Co., Santa Ana Mts., S. California

Loc.: 3000 feet S. and 200 feet W. of NE. corner, sec. 7, T.5S., R.7W.; about 1000 feet due north of the HoLz ranch house, outcrop on the lower SW. slope of the ridge just west of Ladd and Mustang Canyons: (P15-34)

Str. position: Baker Canyon sandstone member; platy calcareous layers in the upper part of the member

Fossils: Subprionocyclus neptuni (GEINITZ), Sciponoceras aff. S. bohemicum (FRITSCH)

Age: Upper Turonian

Coll.: W. P. POPENOE, 5/19/1934 
CIT. 1068, 1069

Area: Santiago Peak Quad., Orange Co., Santa Ana Mts., S. California

Loc.: Faulted area on south side of Silverado Canyon between Wildcat and White Canyons. 1068 is 1100 feet E. and 3200 feet S. of NW. corner, sec. 16, T.5S., R.7W.; from small gully back (east) of abandoned farm and just above a spring, about 3.5 miles S. $72^{\circ} \mathrm{E}$. of the mouth of Silverado Canyon; 1069 is 1100 feet E. and 2800 feet $\mathrm{S}$. of the same corner, 400 feet north along the banks of the next small gully to the north.

Str. position: Top of Baker Canyon sandstone member

Fossils: Sciponoceras aff. S. bohemicum (FRITSCH)* [1069], Scaphites cf. gillisi ANDERSON [1068]

Age: Upper Turonian

Coll.: W. P. Popenoe \& G. H. ANderson, 5/15/1934

CIT. 1070

Area: Santiago Peak Quad., Orange Co., Santa Ana Mts., S. California

Loc.: About 1600 feet N. $5^{\circ}$ E. of CIT. 1068 and 1700 feet S. and 1200 feet E. of NW. corner, sec. 16, T.5S., R.7W.; uppermost hard sandstone cropping out along Forest Service road on south side of Silverado Canyon in fault-block between White and Wildcat Canyon, near crest of ridge

Str. position: Baker Canyon sandstone

Fossil: Sciponoceras aff. S. bohemicum (FRITSCH) *

Age: Upper Turonian

Coll.: W. P. Popenoe, 3/31/1934

CIT. 1159

Area: Calabasas Quad., Los Angeles Co., Simi Hills, S. California

Loc.: 600 feet N.23 W. of SE. corner of sec. 33, T.2N., R.17W.; prominent fossil bed on crest of spur between forks of Dayton Canyon, about 400 feet E. of the Los Angeles-Ventura Co. line

Str. position: Calacerous sandstone at base of exposed Cretaceous section

Fossil: Metaplacenticeras pacificum (SMITH) (abundant)

Age: Upper Campanian

Coll.: Robt. Durbin, H. L. \& W. P. Popenoe, 6/21/1935

CIT. 1183 [=CAS. 28172]

Area: Paradise Quad., Butte Co., E. Sacramento Valley

Loc.: SE. $1 / 4$ of sec. 35, T.22N., R.1E.; bluff about 200 feet above the stream bed, on right bank of Chico Creek, due west of Ten-mile house

Str. position: Chico formation (s.s.) (upper part)

Fossils: Baculites chicoensis TraSk, Inoceramus subundatus MeEK

Age: Campanian

Coll:: W. P. Popenoe \& Alex Clark

CIT. 1190

Area: Millville Quad. (Redding area), Shasta Co., NE. Sacramento Valley

Loc.: 1816 feet $\mathrm{N} .16^{\circ} 20^{\prime} \mathrm{E}$. of SE. corner of sec. 6 [or 5 ?], T.32N., R.3W.; Shale bank on east side of Bella Vista-Sherman road along Dry Creek, about 1.1 miles north of intersection of road with Alturas-Redding highway: (P1-36)

Str. position: Member II (basal part)

Fossils: Romaniceras deverioide (Grossouvre), Mesopuzosia sp.

Age: Turonian (probably middle part)

Coll.: W. P. Popenoe \& Carl AhLroth, 6/9/1936 
CIT. 1195

Area: Redding Quad. (15-minute) (Redding area), Shasta Co., NE. Sacramento Valley

Loc.: 2000 feet E. and 2500 feet S. of NW. corner, sec. 6, T.32N., R.3W.; in bed of Stinking Creek, about midway between two north-south wire fences across Creek

Str. position: Member I, one-foot fossiliferous layer in cross-bedded sandstone

Fossil: Tragodesmoceras ashlandicum (ANDERSON)*

Age: Turonian

Coll.: POPENOE \& AhLROTH, 6/21/1936

CIT. 1208

Area: Millville Quad. (Redding area), Shasta Co., NE. Sacramento Valley

Loc.: About 1700 feet nearly due west of SE. corner, sec. 4, T.32N., R.3W.; about one mile north of Alturas-Redding highway, in channel of Salt Creek: (P30-30)

Str. position: Member I (thick-bedded, coarse sandstone near the base)

Fossil: Tragodesmoceras ashlandicum (ANDERSON)*

Age: Turonian

Coll.: Popenoe \& Ahlroth, 6/27/1936

CIT. 1235

Area: Millville Quad. (Redding area), Shasta Co., NE. Sacramento Valley

Loc.: Almost on south $1 / 4$ corner section 16, T.32N., R.2W.; 2000 feet S.32 ${ }^{\circ}$ E. of Hathaway Bros ranch house, just south of section line fence, SE. side of Oak Run Valley near foot of slope leading up to ridge

Str. position: Member V (lower part)

Fossil: Inoceramus cordiformis SowERBY (typical)

Age: Upper Coniacian or Lower Santonian

Coll.: W. P. Popenoe \& Ahlroth, 7/6/1936

CIT. 1244

Area: Millville Quad. (Redding area), Shasta Co., NE. Sacramento Valley

Loc.: Approximately at the median point of E. boundary of SE. 1/4 (1300 feet N. of SE. corner), sec. 6, T.32N., R.1W.; loose fossiliferous slab on south side of small SW. flowing tributary to Clover Creek, about 1/4 mile SE. of the Falls, and just across the gully south from outcrops of Jurassic metavolcanics

Str. position: Member VI (?), according to PoPenoe; could be Member IV or V in MATSUMOTo's opinion

Fossil: Baculites schencki Matsumoto*

Age: Lower Senonian

CIT. 1246

Area: Millville Quad. (Redding area), Shasta Co., NE. Sacramento Valley

Loc.: SE. $1 / 4$ of NE. 1/4, sec. 13. T.32N., R.2W.; loose boulder on hill slope on east side of 1000 feet hill, (Clover Creek, about 0.3 mile NE. of REINECKER's ranchhouse: (P59-36)

Str.position: Presumably Member V (?)

Fossil: Allocrioceras (?) sp. indet.

Age: Uncertain

Coll.: W. P. Popenoe, Aug. 1936

CIT. 1247

Area: Millville Quad. (Redding area), Shasta Co., NE. Sacramento Valley

Loc.: SW. $1 / 4$ of NE. $1 / 4$, sec. 13, T.32N., R.2W.; hard fossiliferous sandstone boulder in slabs on slope of spur, north side of Clover Creek, about 0.2 mile NE. of 
REINECKE's ranch-house

Str. position: Presumably Member V (?)

Fossil: Baculites cf. schencki Matsumoto

Age: Lower Senonian

Coll.: W. P. Popenoe, 8/1/1936

CIT. 1260

Area: Millville Quad. (Redding area), Shasta Co., NE. Sacramento Valley

Loc.: NW. $1 / 4$ of NW. $1 / 4$ of sec. 9, T.32N., R.2W.; concretions in shales, on bank of small gully tributary to Swede Creek

Str. position: Presumably Member IV (lower part)

Fossil: Baculites capensis Woods (abundant)

Age: Lower Senonian

Coll.: W. P. Popenoe, 4/12/1937

CIT. 1264

Area: Millville Quad. (Redding area), Shasta Co., NE. Sacramento Valley

Loc.: About 4250 feet N.33 ${ }^{1 / 4}$ E. of SW. corner of sec. 9, T.32N., R.3W.; outcrop in bed of a small gully tributary to Little Cow Creek

Str. position: Member III, massive, brown sandstone (slightly lower than loc. CIT. 1266)

Fossil: Subprionocyclus sp. juvenile (cf. inner whorl of S. neptuni (GeINITz))

Age: Upper Turonian

Coll.: W. P. Popenoe

CIT. 1266

Area: Millville Quad. (Redding area), Shasta Co., NE. Sacramento Valley

Loc.: Approximately 3400 feet N.45 ${ }^{\circ}$ E. of SW. corner of sec. 9, T.32N., R.3W.; bank of Little Cow Creek

Str. position: Member III (lower than loc. CIT. 1346)

Fossils: Subprionocyclus neptuni (GEINITZ), Inoceramus aff. I. teshioensis NAGAo \& Matsumoto [=? I. costellatus Woods]

Age: Upper Turonian

Coll.: W. P. Popenoe

CIT. 1268

Area: Millville Quad. (Redding area), Shasta Co., NE. Sacramento Valley

Loc.: NW. $1 / 4$, NE. $1 / 4$, sec. 9 , T.32N., R.3W.; in a gully leading south to Little Cow Creek

Str. position: Member III (near its base)

Fossil: Otoscaphites sp.

Age: Turonian (for Member III)

Coll.: W. P. Popenoe, 4/16/1937

CIT. 1277

Area: Millville Quad. (Redding area), Shasta Co., NE. Sacramento Valley

Loc.: About the center of NW. $1 / 4$ of sec. 20, T.32N., R.1W.; [for 1277, 78, 79] "three distinct fossiliferous sandstone beds in an exposure from the stream bed to the top of the north side of the bank of Old Cow Creek, about 75 feet stratigraphically

Str. position: Probably Member V

Fossil: Baculites cf. boulei Collignon

Age: Lower Senonian

Coll. H. V. CHurch 
CIT. 1282

Area: Millville Quad. (Redding area), Shasta Co., NE. Sacramento Valley

Loc.: Approximately 1300 feet due north of SE. corner, sec. 32, T.32N., R.2W.; slab of flat-lying sandstone, just above conglomerate on south bank of gully opening into Clover Creek Valley

Str. position: Member V (lower part)

Fossil: Baculites cf. boulei Collignon

Age: Lower Senonian

Coll.: L. NELSON \& V. CHURCH, 7/25/1936

CIT. 1285

Area: Millville Quad. (Redding area), Shasta Co., NE. Sacramento Valley

Loc.: SE. $1 / 4$ of SW. $1 / 4$ of sec. 2 , T.32N., R.2W.; just below the letter "e" of Price Hollow of the map (Millville Qu.), Price Hollow: (P34-36)

Str. position: Member V

Fossil: Baculites ef. boulei CollignoN

Age: Lower Senonian

Coll.: Carl W. Ahrroth

CIT. 1345

Area: Millville Quad. (Redding area), Shasta Co., NE. Sacramento Valley

Loc.: About 150 yards S. of N. line of S. 1/2, sec. 4, T.32N., R.2W.; in bed of Swede Creek ["French Creek" on topo-sheet], Hathaway Bros ranch, N. of Oak Run: (P25-36)

Str. position: Member III-IV transition, according to PopenoE. The locality is isolated from the type areas of Members III and IV; Matsumoto doubts Popenoe's assignment, suggesting possibility of lower part of Member III covered disconformably by Member IV

Fossil: Romaniceras deverioide (GRossouvRE) *

Age: Turonian (probably middle part)

Coll.: W. P. Popenoe \& Carl Ahlroth, 6/30/1936

CIT. 1346

Area: Millville Quad. (Redding area), Shasta Co., NE. Sacramento Valley

Loc.: SE. $1 / 4$ of SW. $1 / 4$ of sec. 9, T.32N., R.3W.; left bank of Little Cow Creek, about 75 yards upstream (NE.) from the intersection of the Creek with the $S$. line of sec. $9 ; 1 / 4$ mile downstream from the Walter MELTON farmhouse: (P2;-37)

Str. position: Member III (relatively upper part)

Fossils: Neophylloceras ramosum (MEEK)* [=Phylloceras vaculae ANDERSON], Subprionocyclus normalis (ANDERSON)* (abundant), Tetragonites glabrus (JIMBO) [=T. jacksonensis ANDERSON], Scalarites cf. mihoensis WRIGHT \& Matsumoto, Mesopuzosia sp. juvenile, Inoceramus cf. teshioensis Nagao and Matsumoto

Age: Upper Turonian

Coll.: W. P. Popenoe \& Jane Hoel, 7/8/1937

CIT. 1347

Area: Ono Quad., Shasta Co., NW. Sacramento Valley

Loc. and Str. position: Near center of sec. 3, T.29N., R.6W.; from the highest upper Cretaceous beds exposed on Roaring River, about 1/4 mile downstream from the old ranch house on the Drew place: (P24-33)

Fossils: Damesites damesi intermedius MATsumoto* [=Kotoceras frazierense ANDERSoN, 1958, holotype], Gaudryceras denseplicatum (Јімво) [=Lytoceras (Gaudryceras) aff. tenuiliratum of ANDERSON, 1958]

Age: Upper Turonian or Coniacian

Coll.: W. P. Popenoe \& W. A. Findlay, 8/25/1933 
CIT. 1398

Area: Sucia Island, San Juan Co., Washington

Loc.: "South side of peninsula bounding Fossil Cove on south"

Str. position: Sandy shales stratigraphically 50-40 feet above the basal conglomerate of the Upper Cretaceous in this area

Fossils: Canadoceras cf. newberryanum (MEEK), Gaudryceras cf. denmanense Whiteaves, Inoceramus subundatus MeEK (abundant)

Age: Campanian

Coll.: $\quad$ R. Durbin \& H. L. \& L. \& W. P. Popenoe, $7 / 23 / 1935$

CIT. 1400

Area: Sucia Island, San Juan Co., Washington

Loc.: "Bluffs on south side of Fossil Cove at east end of Sucia Island"

Str. position: No record, but probably about the same as CIT. 1398

Fossils: Neophylloceras cf. ramosum (MEEK), Desmophyllites diphylloides (FoRBES), Canadoceras sp., Hoplitoplacenticeras sp., Pseudoxybeloceras cf. lineatum (GABB), Inoceramus vancouverensis SHUMARD

Age: Campanian

Coll.: R. Durbin, H. L. \& W. P. Popenoe, 7/24/1935

CIT. 1436

Area: Millville Quad. (Redding area), Shasta Co., NE. Sacramento Valley

Loc.: About $1 / 2$ mile SW. of NE. corner, sec. 35, T.33N., R.3W.; about $1 / 4$ mile N. of the Alturas-Redding highway (US. 299), and 1.5 miles NE. along highway from the bridge over Salt Creek

Str. position: Member I (upper third)

Fossil: Inoceramus hobetsensis NaGao \& Matsumoto

Age: Turonian (probably middle part)

Coll.: W. P. Popenoe, 3/18/1940

CIT. 1444

Area: Redding Quad. (1:125000), Shasta Co., NE. Sacramento Valley

Loc.: Approximately west of center of east [or west ?] line, sec. 36, T.33N., R.3W.; $1 / 4$ mile SW. of Redding-Alturas highway, NE. of Salt Creek Bridge

Str. position: Member I (sandstone)

Fossil: Tragodesmoceras ashlandicum (ANDERSON) *

Age: Turonian

Coll.: W. P. Popenoe, 3/22/1940

CIT. 1531

Area: Millville Quad. (Redding area), Shasta Co., NE. Sacramento Valley

Loc.: $\quad 0.4$ mile S. $12^{\circ} \mathrm{W}$. of NE. corner of sec. 4, T.32N., R.3W.; in gray sandy shales cropping out in gullies 100 yards S. or US. highway 299: (=TM. 2005, LSJU. 3291)

Str.position: Member II

Fossils: Subprionocyclus sp. juvenile, resembling the inner whorls of S. neptuni (GEINITZ), Otoscaphites sp.

Age: Turonian

Coll.: W. P. Popenoe \& Carl Ahlroth, 7/7/1936

CIT. 1532

Area: Millville Quad. (Redding area), Shasta Co., NE. Sacramento Valley

Loc.: 800 feet N.38 W. of SE. corner of sec. 4, T.32N., R.3W.: concretions in shale near right bank of Little Cow Creek: (P48-36)

Str.position: Member II (near top) 
Fossils: Jimboiceras (?) sp. Scalarites ef. mihoensis WRIGHT \& MATSUmoto*, Scaphites gillisi ANDERSON, Otoscaphites puerculus (JIMBo)

Age: Turonian

Coll.: W. P. Popenoe \& Carl Ahlroth, 7/10/1936

CIT. 1533

Area: Millville Quad. (Redding area), Shasta Co., NE. Sacramento Valley

Loc.: 650 feet $\mathrm{N} .41^{\circ} \mathrm{W}$. of SE. corner of sec. 4, T.32N., R.3W.; concretions in shale, right bank of Little Cow Creek

Str. position: Member II (near top)

Fossils: Jimboiceras or Kossmaticeras (?) sp., Tetragonites glabrus (Jімво), Scalarites cf. mihoensis Wright \& MATSumoto, Scaphites condoni Anderson, Otoscaphites puerculus (JiмBo), Inoceramus cf. tenuistriatus Nagao \& Matsumoto

Age: Turonian

Coll.: W. P. Popenoe \& Carl Ahlroth

CIT. 1537

Area: Calabasas Quad., Ventura Co., Simi Hills, S. California

Loc.: About 1745 feet $\mathrm{N}^{\circ} 65^{\circ} \mathrm{W}$. of SE. corner of sec. 28, T.2N., R.17W.; north side of the ridge between Dayton Canyon and Porter Canyon (south fork of Dayton Canyon), SE. slope of the Simi Hills

Str. position: Calcareous sandstone at base of section

Fossils: Metaplacenticeras sp. (abundant), Inoceramus cf. subundatus MEEK

Age: Campanian

Coll:: No record

CIT 1590

Area: Burney Quad. (1:125000) (Redding area), Shasta Co., NE. Sacramento Valley

Loc.: Approximately at the middle of N. line of sec. 21, T.32N., R.1W.; 750 feet upstream from mouth of gully tributary to Old Cow Creek at the first bridge on highway over the creek, east of Clover Creek school

Str. position: Member V (rather massive sandstones)

Fossil: Inoceramus cf. cordiformis SowERBY

Age: Lower Senonian

Coll.: W. P. Popenoe \& W. M. TOvelL, 9/15/1941

CIT. 1598

Area: Millville Quad. (Redding area), Shasta Co., NE. Sacramento Valley

Loc.: Approximately 0.4 mile west of SE. corner, sec. 33, T.33N., R.3W.; 150 feet N. of the township line; left bank of a small gully in a field north of Burney Road, US. 299 highway, between Salt and Dry Creeks: (P2-41)

Str. position: Member II

Fossil: Tetragonites glabrus (JIMBo)*

Age: This species is common in the Turonian of California, but long ranging (Turonian-Santonian) in Japan

Coll.: W. P. Popenoe \& G. P. Zebal, 8/2/1941

LSJU. 1628

Area: Coalinga Quad., Fresno Co., W. San Joaquin Valley

Loc.: SW. $1 / 4$, SE. 1/4 of sec. 33, T.19S., R.14E.; 0.5 mile north of Los Gatos Creek

Str. position: Lower 300 feet of 800 feet Ragged Valley shale

Fossils: Baculites ef. inornatus MeEK, other shells

Age: Campanian

Coll.: MULler \& ReINHARdT 
LSJU. 1629

Area: Coalinga Quad., Fresno Co., W. San Joaquin Valley

Loc.: About middle of south line, NE. 1/4, sec. 4, T.20S., R.14E.; on the bank of Los Gatos Creek at its strong curve

Str. position: Lower 300 feet of 800 feet Ragged Valley shale

Fossils: Hauericeras sp., Baculites lomaensis ANDERSON*

Age: Upper Campanian or Lower Maestrichtian

Coll.: S. W. Muller \& ReINHARDT, 5/11-12/1935

LSJU. 1630

Area: Coalinga Quad., Fresno Co., W. San Joaquin Valley

Loc.: Just north of middle of S. line, SE. 1/4, sec. 4, T.20S., R.14E.; on the bank of Los Gatos Creek

Str. position: "Ragged Valley shale", within lower 300 feet

Fossil: Baculites occidentalis MEEK* [mislabelled as B. chicoensis TRASK]

Age: Upper Campanian

Coll.: Stanf. Geol. Surv.

LSJU. 1631

Area: Coalinga Quad. (1:125000) [Joaquin Rocks Quad. (15-minute)], Fresno Co., W. San Joaquin Valley

Loc.: Slightly east of center of sec. 7, T.19S., R.15E.; Joaquin Ridge

Str. position: Probably Ragged Valley shale formation (lower part ?)

Fossil: Baculites lomaensis ANDERson* [mislabelled as B. vagina ForBEs] (a large number of specimens, over 100 , although fragmentary)

Age: Upper Campanian or Lower Maestrichtian

Coll.: MUlLer \& ReINHARDT, 5/11-12/1935

LSJU. 1806a [= CAS. 27842]

Area: Chico Quad. $(1: 125000)$, Butte Co., E. Sacramento Valley

Loc.: Center of sec. 35, T.23N., R.2E.; about 7 miles NE. of Chico between road and Chico Creek [=Big Chico Creek]; also in creek

Str. position: Chico formation in the type area (see TAFF, HANNA, \& CRoss, 1940, for CAS. 27842)

Fossil: Baculites chicoensis Trask

Age: Campanian

Coll.: S. W. Muller, T. W. Dibblee Jr., and E. BAIley, 6/14/1935

LSJU. 1806d [= CAS. 28173]

Area: Chico Quad. (1:125000), Butte Co., E. Sacramento Valley

Loc.: South central part of sec. 12 , T.23N., R.2E.; on road cut also in west bank of creek directly below Chico Creek

Str. position: Chico formation (see TAFF, HANNA, \& Cross, 1940 for CAS. 28173)

Fossil: Inoceramus cf. japonicus NAGAo and MATsumoto forma $\gamma(\div I$. undulatoplicatus RöMER)

Age: Santonian

Coll.: S. W. Muller, T. W. Dibblee Jr., \& E. Bailey

LSJU. 1840

Area: Tesla Quad., Alameda Co., Bay Area

Loc.: Arroyo del Valle, JoRDAN ranch (8 miles SE. of Livermore) (no indication of sec. T. \& R.)

Str. position: No record 
Fossils: Metaplacenticeras pacificum (SMITH), Baculites aff. B. anceps LAMARcK* (abundant)

Age: Upper Campanian

Coll.: J. P. SMITH

LSJU. 1997

Area: Rumsey Hills, Morgan Valley Quad., Yolo Co., SW. Sacramento Valley

Loc.: "On east edge of swimming pool at county park in Cache Creek Portal, about 2.5 miles northwest of Rumsey

Str. position: Shale (silty shale) along south side of cross fault and above massive sandstones (highest part of Sites formation or basal part of Funks formation)

Fossils: Scaphites sp., Otoscaphites cf. puerculus (Јімво), Inoceramus sp. indet.

Age: Upper Turonian or Coniacian

Coll.: J. M. KIRBY, 1933

LSJU. 1998

Area: Rumsey Hills, Capay Quad., Yolo Co., SW. Sacramento Valley

Loc.: Approximately 700 feet E. and 1500 feet N. from SW. corner, sec. 24, T.10N., R.3W.; top of ridge

Str. position: Guinda formation according to the geologic map, Capay Valley, Pacific sec. AAPG. Spring field trip, May 7-8, 1954; may be Sites formation, depending on the position of a fualt

Fossils: Bostrychoceras aff. indicum (StoliczKa), Scalarites (?) sp., Inoceramus sp. (group of I. naumanni)

Age: Upper Turonian (?) or Lower Senonian

Coll.: J. M. KIRBY

LSJU. 1999

Area: Rumsey Hills, Capay Quad., Yolo Co., SW. Sacramento Valley

Loc.: Approximately 1550 feet west and 2000 feet north from SE. corner, sec. 4, T.10N., R.3W.; west of Eckhard sliding in canyon bottom, on west side Capay Valley, in silty rock

Str. position: Uppermost part of Sites formation (?)

Fossils: Scaphites sp. (cf. yokoyamai JiMBo), Otoscaphites cf. puerculus (JIMBo), bituberculate pachydiscid ammonite (Pseudojacobites or Menuites indet.), Inoceramus sp. (group of I. lamarcki-cordiformis)

Age: Turonian or Coniacian

Coll.: J. M. KIRBY \& T. H. CROOK, 1933

LSJU. 2001

Area: Rumsey Hills, Rumsey Quad., Yolo Co., SW. Sacramento Valley

Loc.: Approximately 300 feet W. and 1150 feet S. from NW. corner, sec. 30, T.12N., R.3W.; on ridge, west side Capay Valley

Str. position: Funks formation

Fossils: Gaudryceras sp. (cf. G. tenuiliratum YABE or G. denmanense Whiteaves), Baculites schencki MAтSUмото, Hyphantoceras cf. venustum (YABE)

Age: Coniacian

Coll.: J. M. KIRBY \& T. H. CROOK

LSJU. 2003

Area: Rumsey Hills, Rumsey Quad., Yolo Co., SW. Sacramento Valley

Loc.: About 1000 feet W. and 1200 feet S. from NE. corner sec. 6, T.11N., R.2W.; on ridge top, west side Capay Valley

Str. position: Funks formation 
Fossil: Gaudryceras sp. immature (cf. G. tenuiliratum YABE)

Age: Senonian

Coll.: J. M. KIRBY \& T. H. CROOK, 1933

LSJU. 2004

Area: Rumsey Hills, Rumsey Quad., Yolo Co., SW. Sacramento Valley

Loc.: Approximately 1300 feet W. and 1200 feet N. from SW. corner, sec. 19, T.12N., R.3W.; on ridge top, west side Capay Valley, southwest of Rumsey

Str. position: Funks formation

Fossils: Baculites sehencki Matsumoto*, Scalarites sp. (densicostate form), prism of a large Inoceramus

Age: Coniacian

Coll.: J. M. KIRBY \& T. M. CROOK, 1933

LSJU. 2006

Area: Rumsey Hills, Capay Quad., Yolo Co., SW. Sacramento Valley

Loc.: Approximately 700 feet N. and 1500 feet E. from NW. corner sec. 30, T.10N., R.2W.; south of Cadanassa, on north side Calderon canyon, west side Capay Valley

Str. position: Laminated medium-grained sandstone, which is referred to "Funks sandstone" according to NCGS.-AAPG. Spring Field Trip Guide Geol. Map, May 7-8, 1954, but may be upper part of Sites sandstone

Fossil: Neophylloceras cf. ramosum (MEEK)

Coll.: J. M. KIRBY, 1933

LSJU. 2227

Area: Cholame Quad. (1:125000), Monterey Co., range west of San Joaquin Valley Loc.: Sec. 6, T.24S., R.16E.; in dry wash at the west end of a glauconitic sandstone Str. position: No formational name

Fossil: Baculites rex ANDERSON

Age: Maestrichtian or uppermost Campanian

Coll.: A. L. Badbuy, March 1940

LSJU. 2251

Area: Panoche Quad. (1:125000), Fresno Co., W. San Joaquin Valley

Loc.: 600 feet S., 800 feet W., of NE. corner, sec. 12, T.15S., R.11E.; west slope of Panoche Hills

Str. position: Concretionary sandstone at the top of Panoche group

Fossils: Baculites columna MORTON* [previously misidentified as $B$. cf. fairbanksi ANDERSON], Glyptoxoceras sp., Diplomoceras sp., many shells

Age: Maestrichtian (?)

Coll.: H. G. Schenck, S. W. Muller, R. C. Brown, \& M. B. Payne

LSJU. 2554

Area: Calabasas Quad., Los Angeles-Ventura Counties, Simi Hills, S. California

Loc.: No record of sec. T. \& R.; Dayton Canyon, south side of the Simi Hills

Str. position: No record

Fossils: Anapachydiscus cf. arrialoorensis (StoliczkA), Metaplacenticeras sp., Baculites cf. inornatus MEEK, other shells

Age: Upper Campanian

Coll.: George Richards, Jr.

LSJU. 2571

Area: Panoche Quad. (1:125000), Merced Co., W. San Joaquin Valley

Loc.: 950 feet E. and 2650 N. of SW. corner, sec. 28, T.11S., R.10E.; on south bank Ortigalita Creek 
Str. position: Calcareous conglomerate, near the top of the Panoche group equivalent

Fossil: Diplomoceras sp. (a curved whorl, with elliptical cross section, showing the typical suture)

Age: Maestrichtian (?)

Coll.: C. F. Green \& M. B. Payne, 8/10/1942

LSJU. 2609

Area: Paradise Quad. (Chico area), Butte Co., E. Sacramento Valley

Loc.: SE. $1 / 4$ of sec. 23, T.23N., R.2E.; east bank of Big Chico Creek, 3.6 miles along the county road from "Ten-mile house" (map locality)

Str. position: Chico formation (s.s.) in the type area, lower part of the upper half of the formation

Fossils: Canadoceras yokoyamai (JIMBo)*, Pachydiscus buckhami UsheR*, Submortoniceras chicoense (TRASK)* (a large number of specimens showing variation), Ryugasella ryugasensis WRIGHT \& MATSUMOTO*, Pseudoxybeloceras lineatum (GABB) *, Baculites chicoensis TrASK*, many other shells

Age: Campanian (probably relatively lower part)

Coll.: R. E. Соок, 1947-48

LSJU. 2709

Area: Capay Quad., Yolo Co., SW. Sacramento Valley

Loc.: 1100 feet N., 350 feet E. of SW. corner, sec. 2, T.8N., R.2W.; south side of Enos Canyon about 1500 feet west of a house in second of three recent gullies; fossils in 2 feet limestone reef partially buried in gully and from float in gully

Str. position: Uppermost shale member of the Upper Cretaceous, exposed in the area; probably upper part of the Forbes formation, but possibly higher

Fossils: Neophylloceras ramosum (MEEK), Desmophyllites diphylloides (FORBEs), Metaplacenticeras sp.

Age: Upper Campanian

Coll.: W. E. KENNETT \& Stanley MCCoy, Sept. 1943

LSJU. 2711

Area: Redding Quad. (1:125000) (Redding area), Shasta Co., NE. Sacramento Valley Loc.: S. line of sec. 9, T.32N., R.3W.; left bank of Little Cow Creek

Str. position: Member III, about 200 feet above its base

Fossil: Subprionocyclus normalis (ANDERSON) (abundant)

Age: Upper Turonian

Coll.: W. P. Popenoe, 6/23/1942

LSJU. 2732

Area: Tesla Quad., Alameda Co., Bay area

Loc.: Grid Coordinates 930.5-1647.6, Arroyo del Valle

Str. position: "Del Valle formation"

Fossils: Desmophyllites diphylloides (FoRBES)*, Metaplacenticeras cf. pacificum (Sмiтн), Gaudryceras sp. juvenile

Age: Upper Campanian

Coll.: L. W. FunkHouser, 6/7/1948

LSJU. 2734

Area: Tesla Quad., Alameda Co., Bay area

Loc.: Grid Coordinates 931.75-1646.65, Arroyo del Valle

Str. position: "Del Valle formation"

Fossils: Metaplacenticeras cf. pacificum (SMITH), Baculites aff. B. anceps LAMARCK* Age: Upper Campanian

Coll.: L. W. Funkhouser, 6/7/1948 
LSJU. 2735

Area: Tesla Quad. (15 minute series), Alameda Co., Bay area

Loc.: Grid Coordinates 930.45-1645.3, NE. 1/4, sec. 23, T.4S., R.2E.; Rocky Ridge

Str. position: "Del Valle formation"

Fossils: Neophylloceras ramosum (MEEK) (immature), Subprionocyclus normalis (ANDERSON) (abundant)

Age: Upper Turonian

Coll.: L. W. FunkHOUSER, 6/7/1948

LSJU. 2747

Area: Coalinga Quad., Fresno Co., W. San Joaquin Valley

Loc.: Sec. 16, T.21S., R.14E.; Juniper Ridge

Str. position: Lower Wartham shale

Fossil: Turrilites (Euturrilites) cf. scheuchzerianus Bosc

Age: Cenomanian

Coll.: S. W. MULLER, 1941

LSJU. 2794

Area: Hildreth Peak Quad., Santa Barbara Co., S. California

Loc.: 6650 feet S.24 ${ }^{\circ} \mathrm{E}$. of Big Caliente Debris Dam

Str. position: Debris Dam sandstone, 30 feet below the top

Fossil: Baculites rex Anderson (See Page, Marks, \& Walker, 1951, p. 1742, for other mega- and micro-fossils.)

Age: Maestrichtian or uppermost Campanian

Coll.: PAGE and others (?)

LSJU. 2795

Area: Hildreth Peak Quad., Santa Barbara Co., S. California

Loc.: $\quad 1 / 2$ mile NW. of 2794

Str. position: Debris Dam sandstone, 60 feet below the top

Fossils: Baculites rex Anderson*, Eutephoceras sp. (see PAGE, Marks, \& Walker, 1951 , p. 1742, for list of other mega- and micro-fossils)

Age: Maestrichtian or uppermost Campanian

Coll.: J. C. MARKs, Oct. 1947

LSJU. 2880

Area: Paradise Quad. (Chico area), Butte Co., E. Sacramento Valley

Loc.: NE. $1 / 4$ of SW. $1 / 4$ of sec. 12, T.23N., R.2E.; east side of Big Chico Creek, 4.5 miles from "Ten-mile house" (map locality), along the county road. This loc. is known as "Rare House Flat"

Str. position: Chico formation (s.s.) in the type area, upper part of the lower half of the formation in this area

Fossils: Baculites capensis Woods*, Gaudryceras cf. denmanense WhITEAvES (juvenile)

Age: Probably Santonian

Coll.: R. E. Cook, 1947-48

LSJU. 2882

Area: Paradise Quad. (Chico area), Butte Co., E. Sacramento Valley

Loc.: 3 miles northeast (map distance) of Concrete Bridge over Big Butte Creek, west bank of Butte Creek

Str. position: Equivalent of upper part of Chico formation (s.s.)

Fossils: Pachydiscus buckhami USHER*, Baculites chicoensis TRASK, Submortoniceras chicoense (TRASK), Inoceramus cf. ezoensis YoKoYama 
Age: Campanian

Coll.: R. E. Cook, 1947-49

LSJU. 2883

Area: Paradise Quad. (Chico area), Butte Co., E. Sacramento Valley

Loc.: Big Chico Creek, 0.5 mile north of O. D. Simmons barn along the county road, east side of road, northeast of Bidwell Park sign "Fossil Bank" on east side of Big Chico Creek

Str. position: Chico formation of the type area, relatively upper part

Fossil: Canadoceras newberryanum (MEEK)

Age: Campanian

Coll.: R. E. CooK, 1947-49

LSJU. 2955

Area: Coalinga Quad., Fresno Co., W. San Joaquin Valley

Loc.: NE. 1/4, sec. 23, T.21S., R.14E.; road cut along Warthan Creek, 300 feet W. of ALCALDE ranch building

Str. position: Sandstone unit above Upper Waltham shale

Fossils: Neophylloceras sp., Mesopuzosia (?) sp. indet., Inoceramus cf. hobetsensis NAGAO and MATSUMOTO

Age: Turonian (probably middle part)

Coll.: No record

LSJU. 2956

Area: Coalinga Quad., Fresno Co., W. San Joaquin Valley

Loc.: NW. 1/4, NW. 1/4, sec. 15, T.21S., R.14E.; approximately 300 feet NE. of hill 1706

Str. position: Upper Wartham shale, 200 feet below the top of this unit

Fossil: Plesiovascoceras sp. (immature)

Age: Lower Turonian

Coll.: S. W. MULLER, 1951

LSJU. 2958

Area: Coalinga Quad., Fresno Co., W. San Joaquin Valley

Loc.: NW. $1 / 4$, NE. $1 / 4$, sec. 17, T.21S., R.14E.; Juniper Ridge

Str. position: Lower Wartham shale, about 800 feet below "Juniper Ridge conglomerate"

Fossil: Acanthoceras cf. evolutum Spath

Age: Upper Cenomanian

Coll.: S. W. MULLER, 3/28/1951

LSJU. 2959

Area: Coalinga Quad., Fresno Co., W. San Joaquin Valley

Loc.: NW. $1 / 4$, NE. $1 / 4$, sec. 17, T.21S., R.14E.; approximately 1500 feet S.70W. of hill 1820, N. of Warthan Creek

Str. position: Lower Wartham shale

Fossils: Forbesiceras cf. obtectum (SHARPE), Turrilites cf. costatus LAMARCK

Age: Cenomanian

Coll.: G. W. MOORE, 4/22/1951

LSJU. 3136

Area: Panoche Quad. (1:125000), San Benito Co., W. San Joaquin Valley

Loc.: 2800 feet E. and 600 feet N. of SW. corner, sec. 8, T.15S., R.11E.; Panoche Hills

Str. position: Lower Marlife shale

Fossils: Baculites cf. schencki Matsumoto, other shells 
Age: Probably Coniacian

Coll.: SutroN, 1952

LSJU. 3138

Area: Panoche Quad. (1:125000), Fresno Co., W. San Joaquin Valley

Loc.: 1850 feet E. of SW. corner on S. line, sec. 24, T.14S., R.10E., Panoche Hills

Str. position: Lower part of Papanatas conglomerate of Panoche group (a boulder or reworked contemporary concretion in the conglomerate)

Fossil: Beudanticeras [Brewericeras ?] cf. hulenense ANDERSON

Age: Albian (for the ammonite)

Coll.: S. W. Muller \& D. W. Sutton, 1952

LSJU. 3140

Area: Panoche Quad. (1:125000), Fresno Co., W. San Joaquin Valley

Loc.: 625 feet N. and 575 feet W. of SE. corner, sec. 6, T.14S., R.11E., Panoche Hills

Str. position: Marlife formation of Panoche group slightly above the predominant sandstone lentil in the middle of the Marlife

Fossil: Inoceramus cf. ezoensis YokoYama

Age: Santonian (?)

Coll.: Sutton, 1952

LSJU. 3190

Area: Capay Quad., Napa Co., SW. Sacramento Valley

Loc.: SW. 1/4, sec. 24, T.8N., R.3W.; Putah Creek, along the north side of highway 28 from Winters to Knoxville, halfway between Redbud Park and Bench Mark 240

Str. position: No record

Fossil: Mortoniceras cf. kiliani (LAsswitz)

Age: Upper Albian

Coll.: N. L. TALIAfERro

LSJU. 3191

Area: Coalinga Quad., Fresno Co., W. San Joaquin Valley

Loc.: NW. $1 / 4$, sec. 17, T.20S., R.14E.; on the divide between the Post and Salt Creeks at an elevation 2050 feet, Alcalde Hills

Str. position: 100 feet stratigraphically above the massive buff-brown sandstone; light grey concretion in shale

Fossil: Inoceramus with divergent ribs (specimen missing)

Age: Uncertain

Coll.: S. W. Muller \& Owen MaRsh, 3/27/1954

LSJU. 3192

Area: Coalinga Quad., Fresno Co., W. San Joaquin Valley

Loc.: On the line between NW. and SW. quarters of sec. 17, T.20S., R.14E.; on the divide between the head of Salt Creek and the south fork of Post Creek, at an elevation of 2150 feet

Str. position: 200 feet stratigraphically below shale; brown, well layered, gritty sandstone bed about 10 feet thick in the massive buff-brown sandstone with "cannon ball" concretions

Fossils: Baculites cf. boulei CoLLIGNoN (?), other mollusca

Age: Lower Senonian (?)

Coll.: S. W. Muller \& Owen MARsh, 3/27/1954

LSJU. 3194

Area: Priest Valley Quad., Merced Co., S. San Joaquin Valley 
Loc.: Sec. 7, T.20S., R.14E.; Alcalde Hills, in the saddle just north of hill "2683" on divide between Post Creek and Mud Run Canyon

Str. position: Not precisely determined

Fossil: Puzosia intermedia intermedia (Kossmat)

Age: Turonian

Coll.: S. W. MUller \& Owen MarSh, 3/26/1954

LSJU. 3197

Area: Coalinga Quad., Fresno Co., W. San Joaquin Valley

Loc.: NW. 1/4, SE. 1/4, sec. 2, T.21S., R.14E.; Cooper Canyon, about 3 miles west of Coalinga

Str. position: No reliable record; shale unit in the southern part of the Alcalde Hills Fossils: Baculites inornatus MEEK, Inoceramus subundatus MEEK

Age: Campanian

Coll:: S. W. Muller \& Owen MarSh

LSJU. 3276

Area: Lodoga Quad., Glenn Co., W. Sacramento Valley

Loc.: 2300 feet N., 300 feet W. of SE. corner of sec. 8, T.18N., R.4W., elevation 425 feet; north extension of Logan Ridge, on its west slope, south of Hunters Creek gorge: (DA 2)

Str. position: Portion of "Antelope shale", below Venado sandstone

Fossils: Desmoceras (Pseudouhligella) dawsoni Whiteaves, Mortoniceras (Durnovarites) aff. quadratum SPATH, Anagaudryceras sp., Hypoturrilites sp.

Age: Upper Albian

Coll.: Robinson, White, Milow, \& S. W. Muller, May 1955

LSJU. 3277

Area: Lodoga Quad., Colusa Co., W. Sacramento Valley

Loc.: Slightly S. of middle of W. line of sec. 33, T.18N., R.4W.; Logan Ridge, $2 / 3$ way up the west slope, about 100 meters south of the Pass, NE. of "Peterson's ranch house"

Str. position: No record, probably a portion of "Antelope shale" below Venado sandstone

Fossil: Pachydesmoceras colusaense (ANDERSON)

Age: Upper Albian (?)

Coll.: Robinson, White, Milow, \& S. W. Muller, May 1955

LSJU. 3278

Area: Ono Quad., Shasta Co., NW. Sacramento Valley

Loc.: No record of sec. T. \& R.; "mouth of Hulen Creek, Cottonwood Creek"

Str. position: No record

Fossil: Pachydesmoceras cf. colusaense (ANDERSON)

Age: Upper Albian (?)

Coll.: W. A. NeLson, 1914

LSJU. 3279

Area: Lodoga Quad., Glenn Co., W. Sacramento Valley

Loc.: 1250 feet N. and 150 feet W. of SE. corner, sec. 8, T.18N., R.4W., elevation 350 feet; north extension of Logan Ridge, on its west side, south of Hunters Creek gorge: (DC 5)

Str. position: "Antelope shale", below Venado sandstone

Fossil: Hyseroceras cf. varicosum (SowERBY)

Age: Upper Albian

Coll.: Robinson, White, Milow, \& S. W. Muller, May 1955 
LSJU. 3280

Area: Lodoga Quad., Colusa Co., W. Sacramento Valley

Loc.: About 1300 feet N., from SW. corner, nearly on W. line, sec. 33, T.18N., R.4W.; NNE. of Sites, PETERson ranch, west slope of Logan Ridge, almost equal to LSJU. 3286 and close to loc. UC. A-4853: (R2NM)

Str. position: "Antelope shale", about 50-75 feet below the base of Venado sandstone

Fossils: Mortoniceras (Durnovarites) cf. nodosocostatum (HoEPEN), Anagaudryceras

(?) sp. (sacya-like body chamber), Idiohamites sp.

Age: Upper Upper Albian

Coll.: Robinson, White, Milow, \& S. W. Muller, May 1955

LSJU. 3281

Area: Lodoga Quad., Colusa Co., W. Sacramento Valley

Loc.: Just NE. of center of NW. 1/4, sec. 6, T.17N., R.4W.; a small gully west side of Antelope Valley, about 3.7 miles NNW. of Sites on map

Str. position: Shale unit, called "Antelope shale"

Fossil: Calycoceras cf. spinosum (Kossmat)

Age: Cenomanian

Coll.: Robinson, White, Milow, \& S. W. Muller

LSJU. 3282 [=TM. 3013]

Area: Lodoga Quad., Colusa Co., W. Sacramento Valley

Loc.: 1700 feet N., 100 feet E., SW. corner, sec. 33, T.18N., R.4W.; second gully south of the Pass of Logan Ridge, NE. of "PETERson's ranch house"

Str. position: "Antelope shale", below Venado sandstone, partly cobble bearing; (a) cobble bearing part, (b) fall from Venado sandstone (?), (c) silty part, 10-25 feet below the base of Venado sandstone, (d) fall probably derived from (c) or below that

Fossils: Desmoceras (Pseudouhligella) ef. dawsoni WhITEAves, rudistid (well preserved), other shells

Age: Probably Upper Albian (see LSJU. 3280)

Coll.: S. Chuber \& T. Matsumoto, 8/27/1957

LSJU. 3283 [=TM. 3015]

Area: Lodoga Quad., Colusa Co., W. Sacramento Valley

Loc.: SW. $1 / 4$, SE. 1/4, T.17N., R.4W.; west slope of Logan Ridge, about $1 / 2$ mile north of "Golden Gate" gorge of Funks Creek

Str. position: Venado sandstone, 3-4 feet above its base

Fossil: Inoceramus cf. labiatus (SchlotheIm)

Age: Probably Lower Turonian

Coll.: S. Chuber \& T. Matsumoto, 10/9/1957

LSJU. 3286 [=TM. 3019]

Area: Lodoga Quad., Colusa Co., W. Sacramento Valley

Loc.: 1300 feet N. from SW. corner, nearly on the W. line of sec. 33, T.18N., R.4W.; west slope of Logan Ridge, a northern branch of the third gully, southward from the Pass, NE. of "Peterson's ranch house"

Str. position: Portion of "Antelope shale"; limy nodule in dark olive-gray siltstone, about 65 feet below the base of Venado sandstone

Fossils: Desmoceras (Pseudouhligella) cf. dawsoni Whiteaves, Anagaudryceras cf. sacya (FORBES), Idiohamites sp.

Age: Upper Albian

Coll.: S. Chuber \& T. MATsumoto, 10/9/1957 
LSJU. 3287

Area: Lodoga Quad., W. Sacramento Valley

Loc.: No precise record of sec., T. \& R.; west slope of Logan Ridge

Str. position: Portion of "Antelope shale" below Venado sandstone

Fossil: Pachydesmoceras sp. [more inflated than the holotype of P. colasaense (ANDERson) but may be within the variation]

Age: Upper Albian (?)

Coll.: No record

LSJU. 3288 [=TM. 2001]

Area: Millville Quad. (Redding area), Shasta Co., NE. Sacramento Valley

Loc.: Just north of S. line of sec. 9, T.32N., R.3W.; Little Cow Creek [=CIT. 1346; may be close to LSJU. 2711]

Str. position: Member III (upper part)

Fossils: Neophylloceras ramosum (MEEK), Subprionocyclus normalis (ANDERSON)* (abundant), Scalarites cf. mihoensis WRIGHT and MATSUMOTO

Age: Turonian

Coll.: W. P. Popenoe \& T. Matsumoto, 8/24/1957

LSJU. 3289 [=TM. 2002]

Area: Millville Quad. (Redding area), Shasta Co., NE. Sacramento Valley

Loc.: SE. 1/4, SE. 1/4, sec. 5, T.32N., R.2W.; Swede Creek (="French Creek")

Str. position: Member IV of POPENOE, 1943, but may be lower part of Member III or upper part of Member II

Fossils: Romaniceras aff. R. pseudodeverianum (JIMBo)*, Eucalycoceras (?) shastense (REAGAN) *, Mesopuzosia pacifica MAtsumoto*

Age: Turonian (probably middle part)

Coll.: W. P. Popenoe \& T. Matsumoto, 8/25/1957

LSJU. 3290 [=TM. 2003]

Area: Millville Quad. (Redding area), Shasta Co., NE. Sacramento Valley

Loc.: SE. (150 yards) of middle of W. line, sec. 4, T.32N., R. 2W.; Swede Creek (=French Creek, Sweden Basin on the Map) [ $\div$ CIT. 1345; CAS. 31231]

Str. position: Member IV, according to a map in POPENOE, 1943, but possibly Member II or lower Member III

Fossil: Romaniceras deverioide (GRossouvre)*

Age: Turonian (probably middle part)

Coll.: W. P. Popenoe \& T. Matsumoto

LSJU. 3291 [=TM. 2005]

Area: Millville Quad. (Redding area), Shasta Co., NE. Sacramento Valley

Loc.: 600 feet W. and 200 feet S. of NE. corner, sec. 4, T.32N., R. 3W.; 2.3 miles by US. highway 299, NE. of Bella Vista [ $\div$ CIT. 1531]

Str. position: Member II, shale with compact calcified nodules

Fossil: Subprionocyclus (?) sp.

Age: Turonian

Coll.: W. P. Popenoe \& T. Matsumoto, $8 / 25 / 1957$

LSJU. 3292 [=TM. 3018]

Area: Lodoga Quad., Colusa Co., W. Sacramento Valley

Loc.: About 1300 feet N. of SW. corner, nearly on W. line of sec. 33, T.18N., R.4W.; west slope of Logan Ridge, the third gully south of the Pass, NE. of "PETERson ranch house", S. branch

Str. position: Basal part of Venado sandstone (higher than LSJU. 3285 \& 3256) 
Fossil: Inoceramus cf. labiatus SchLotherm

Age: Lower Turonian

Coll.: Stewart Chuber \& T. Matsumoto, 10/9/1957

LSJU. 3293 [=TM. 1000]

Area: Oroville Quad., Butte Co., E. Sacramento Valley

Loc.: Approximately 1500 feet S. and 1000 feet E. of NW. corner of sec. 25, T.21N., R.3E.; about $3 / 4$ mile (on map) SWW. of Pentz

Str. position: Probably equivalent of the upper part of the type Chico formation

Fossils: Baculites chicoensis TRASK, Submortoniceras chicoense (TRASK), many other shells

Age: Campanian

Coll:: Stewart Chuber \& T. Matsumoto, 8/20/1957

LSJU. 3294 [=TM. 1017]

Area: Paradise Quad. (Chico area), Butte Co., E. Sacramento Valley

Loc.: Approximately 1100 feet S. and 2500 E. of NW. corner, sec. 35, T.23N., R.2E.; east bank of Big Chico Creek

Str. position: A float probably derived from the upper part of the type Chico formation Fossils: Baculites chicoensis TrASK, other shells

Age: Campanian

Coll.: S. Chuber \& T. Matsumoto, 8/23/1957

LSJU. 3295 [=TM. 1015]

Area: Paradise Quad. (Chico area), Butte Co., E. Sacramento Valley

Loc.: Approximately 1200 feet W. and 1800 feet N. of SE. corner, sec. 23, T.23N., R.2E.; east bank of Big Chico Creek (This locality is about the same as loc. LSJU. 2609.)

Str. position: Upper part of the type Chico formation, about 1300 feet stratigraphically above the base

Fossil: Submortoniceras chicoense (TRASK)

Age: Campanian

Coll.: S. Chuber \& T. Matsumoto, $8 / 23 / 1957$

LSJU. 3296 [=TM. 1016]

Area: Paradise Quad. (Chico area), Butte Co., E. Sacramento Valley

Loc.: Approximately 1500 feet S., 800 feet W. of NE. corner, sec. 23, T.23N., R.2E.; west bank of Big Chico Creek

Str. position: Upper part of the type Chico formation, about 1550 feet stratigraphically above the base

Fossils: Baculites chicoensis TRASK, Inoceramus sp. (fragment of ezoensis type), other shells

Age: Campanian

Coll.: S. Chuber \& T. Matsumoto, 8/23/1957

LSJU. 3297 [=TM. 1014]

Area: Paradise Quad. (Chico area), Butte Co., E. Sacramento Valley

Loc.: Center of E. half of sec. 23, T.23N., R.2E.; west bank of Big Chico Creek

Str. position: Upper part of the type Chico formation about 1600 feet stratigraphically above the base

Fossils: Baculites chicoensis TRASK, Submortoniceras chicoense (TRASK), other shells

Age: Campanian

Coll.: S. Chuber \& T. Matsumoto, 8/23/1957 
LSJU. 3298 [=TM. 1013]

Area: Paradise Quad. (Chico area), Butte Co., E. Sacramento Valley

Loc.: Approximately 1200 feet N. of SE. corner on W. line, sec. 13, T.23N., R.2E.; east bank of Big Chico Creek

Str. position: Lower part of upper half of the type Chico formation, about 1300 feet above the base

Fossils: Canadoceras sp., Baculites chicoensis Trask, other shells

Age: Campanian

Coll.: S. Chuber \& T. Matsumoto, 8/23/1957

LSJU. 3299 [=TM. 1012]

Area: Paradise Quad. (Chico area), Butte Co., E. Sacramento Valley

Loc.: Approximately 200 feet N. of SE. corner on W. line, sec. 13, T.23N., R.2E.; east bank of Big Chico Creek

Str. position: Lower part of upper half of the type Chico formation, about 1150 feet above the base

Fossils: Canadoceras sp., other shells

Age: Campanian

Coll.: S. Chuber \& T. Matsumoto, 8/23/1957

LSJU. 3300 [=TM. 1011]

Area: Paradise Quad. (Chico area), Butte Co., E. Sacramento Valley

Loc. Approximately 2300 feet N. of SE. corner on W. line, sec. 13, T.23N., R.2E.; east bank of Big Chico Creek

Str. position: Lower part of upper half of the Chico formation (s.s.), about 1140 feet above the base

Fossils: Canadoceras yokoyamai (JIMBo), Baculites sp., other shells

Age: Campanian

Coll: : S. Chuber \& T. Matsumoto, 8/23/1957

LSJU. 3301 [=TM. 1010]

Area: Paradise Quad. (Chico area), Butte Co., E. Sacramento Valley

Loc.: Approximately 2300 feet S., 150 feet E. of NW. corner, sec. 13, T.23N., R.2E.; west bank of Big Chico Creek

Str. position: Chico formation, 1100 feet above the base

Fossils: Baculites chicocnsis Trask, Canadoceras sp., other molluscan shells

Age: Campanian

Coll.: S. Chuber \& T. Matsumoto, 8/23/1957

LSJU. 3302 [=TM. 1009]

Area: Paradise Quad. (Chico area), Butte Co., E. Sacramento Valley

Loc.: Approximately 2000 feet S., 450 feet E. of NW. corner, sec. 13, T.23N., R.2E.; west bank of Big Chico Creek

Str. position: Upper part of lower half of the type Chico formation, approximately 1000 feet $( \pm 10$ feet) above the base

Fossils: Baculites cf. capensis, Inoceramus sp. (large form of ezoensis group), Glycymeris and many other shells

Age: Santonian (?)

Coll.: S. Chuber \& T. Matsumoto, 8/23/1957

LSJU. 3303 [=TM. 1008]

Area: Paradise Quad. (Chico area), Butte Co., E. Sacramento Valley

Loe.: Approximately 2000 feet S., 500 feet E. of NW. corner, sec. 13, T.23N., R.2E.; east bank of Big Chico Creek 
Str. position: Upper part of lower half of type Chico formation, about 990 feet above the base

Fossils: Inoceramus cf. ezoensis YoкоYамA (possibly I. cf. undulatoplicatus), Glycymeris sp.

Age: Santonian

Coll: : S. Chuber \& T. Matsumoto, 8/23/1957

LSJU. 3304 [=TM. 1007]

Area: Paradise Quad. (Chico area), Butte Co., E. Sacramento Valley

Loc.: Approximately 1000 feet E. and 400 feet S. of NW. corner, sec. 13, T.23N., R.2E.; east bank of Big Chico Creek

Str. position: Upper part of lower half of the type Chico formation, about 920 feet above the base

Fossils: Baculites capensis WooDs, many other molluscan shells

Age: Probably Santonian

Coll.: S. Chuber \& T. Matsumoto, $8 / 23 / 1957$

LSJU. 3307 [=TM. 1004]

Area: Paradise Quad. (Chico area), Butte Co., E. Sacramento Valley

Loc.: NW. $1 / 4$, of SW. 1/4, sec. 12, T.23N., R.2E.; west bank of Big Chico Creek

Str. position: Upper part of lower half of the type Chico formation, about 800 feet above the base

Fossils: Inoceramus naumanni YoкоYAмA, Inoceramus ef. undulatoplicatus Römer, other molluscan shells

Age: Santonian

Coll.: T. Matsumoto \& S. ChUber, 8/22/1957

LSJU. 3310 [ $=$ TM. 1001]

Area: Paradise Quad. (Chico area), Butte Co., E. Sacramento Valley

Loc.: NW. $1 / 4$ of SE. 1/4, sec. 1, T.23N., R.2E.; Big Chico Creek

Str. position: A large calcareous concretion (a float) derived from a conglomeratic sandstone in the basal member of the type Chico formation (the closest exposure is about $\mathbf{1 5 0}$ feet stratigraphically above the base)

Fossils: Baculites schencki Matsumoto, other mollusca

Age: Probably Coniacian

Coll.: S. Chuber \& T. Matsumoto, 8/22/1957

LSJU. 3312 [=TM. 201]

Area: Panoche Quad. (1:125000), Fresno Co., W. San Joaquin Valley

Loc.: 1250 feet E., 900 feet S. of NW. corner, sec. 24, T.14S., R.10E.; Papanatas Canyon, west side of the Panoche Hills, on a slope southside of the canyon

Str. position: A calcareous concretion found in the upper part of the Papanatas conglomerate, Panoche group

Fossils: Bhimaites sp., Lechites aff. L. gaudini (Pictet \& CAMPiche), Hamites (?) sp., other shells

Age: Upper Albian or Lower Cenomanian

Coll.: M. B. Payne \& T. Matsumoto, 9/15/1957

LSJU. 3313 [=TM. 109]

Area: Panoche Quad. (1:125000), Fresno Co., W. San Joaquin Valley

Loc.: 1850 feet E., 800 feet S. of NW. corner, sec. 24, T.14S., R.10E.; Papanatas Canyon, west side of the Panoche Hills

Str. position: A large calcareous sandstone concretion found in the sandy matrix of conglomerate, upper part of Papanatas conglomerate, Panoche group 
Fossils: Stomohamites (?) sp., and a coiled ammonite, many other molluscan shells includ. Syncyclonema and Apiotrigonia

Age: Upper Albian or Lower Cenomanian

Coll.: T. Matsumoto, 4/10/1957

LSJU. 3314 [=TM. 131]

Area: Panoche Quad. (1:125000), Fresno Co., W. San Joaquin Valley

Loc.: Approximately center of $1 / 2$ S. of sec. 18, T.14S., R.11E.; upper course of Papanatas Canyon, Panoche Hills, on a slope slightly south of the creek

Str. position: Ortigalita sandstone, Panoche group

Fossils: Lewesiceras-like ammonite, other shells

Age: Turonian or Coniacian (?)

Coll.: T. Matsumoto, 4/11/1957

LSJU. 3315 [=TM. 210]

Area: Panoche Quad. $(1: 125000)$, Fresno Co., W. San Joaquin Valley

Loc.: 1100 feet W., 600 feet N. of SE. corner, sec. T.14S., R.11E.; Panoche Hills

Str. position: A sandstone in the lower part of the Lower Marlife formation, Panoche group (slightly above the boulder conglomerate near the basal part of Marlife formation)

Fossils: Baculites schencki MATSUmoto*, Inoceramus ef. uwajimensis YeHARA, other shells

Age: Coniacian

Coll.: M. B. Payne \& T. Matsumoto, 9/19/1957

LSJU. 3316 [=TM. 31]

Area: Panoche Quad. $(1: 125000)$, Fresno Co., W. San Joaquin Valley

Loc.: 1100 feet S., 100 feet W. of NE. corner, sec. 17, T.14S., R.11E.; Panoche Hills (on a saddle, northeast of Marlife Plateau)

Str. position: A granule-bearing very coarse sandstone patch in $6 \mathrm{~m}$. thick sandstone beds in the Lower Marlife formation, about 1200 feet stratigraphically below the Llanada sandstone lentil in the middle of the Marlife formation, Panoche group

Fossils: Baculites schencki Matsumoto, other shells

Age: Probably Coniacian

Coll.: T. Matsumoto, $4 / 13 / 1957$

LSJU. 3319 [=TM. 11]

Area: Panoche Quad. $(1: 125000)$, Fresno Co., W. San Joaquin Valley

Loc.: 150 feet N., 700 feet E. of SW. corner, sec. 9, T.14S., R.11E.; Panoche Hills, on a small hill top close to LSJU. 3320

Str. position: Lower part of the Upper Marlife formation, Panoche group; about $\mathbf{1 5 0}$ feet stratigraphically above the top of the Llanada sandstone lentil in the middle of the Marlife

Fossils: Baculites capensis WooDs, Anagaudryceras yamashitai (YABE)*

Age: Santonian

Coll.: J. J. Graham, H. G. Schenck, M. B. Payne, \& T. Matsumoto, 4/7/1957

LSJU. 3320 [=TM. 14$]$

Area: Panoche Quad. (1:125000), Fresno Co., W. San Joaquin Valley

Loc.: 100 feet N., 700 feet E. of SW. corner, sec. 9, T.14S., R.11E.; Panoche Hills, a bluff facing a northern branch of Moreno Gulch

Str. position: Lower part of the Upper Marlife formation, Panoche group; about 150 feet stratigraphically above the top of the Llanada sandstone lentil in the middle of the Marlife formation 
Fossils: Baculites capensis Woods* (abundant), Scalarites (?) sp., Anapachydiscus sp. juv., Inoceramus cf. amakusensis NAGAO \& MATsumoto, other shells

Age: Santonian

Coll.: M. B. Payne and T. Matsumoto, 4/8/1957

LSJU. 3323 [=TM. 205]

Area: Panoche Quad. (1:125000), Fresno Co., W. San Joaquin Valley

Loc.: Near center of sec. 15, T.14S., R.11E.; Panoche Hills, in a southern branch of Moreno Gulch

Str. position: Upper part of the Upper Marlife formation, Panoche group

Fossil: Inoceramus sp. (large form)

Age: Campanian ? (because Pachydiscus buckhami UsHer was once obtained from the nearby loc. CAS. 28542 , in the same shale unit)

Coll.: $\quad$ M. B. Payne \& T. Matsumoto, 9/18/1957

LSJU. 3325 [=TM. 207]

Area: Panoche Quad. (1:125000), Fresno Co., W. San Joaquin Valley

Loc.: 2000 feet E., 1000 feet N. of SW. corner, sec. 3, T.14S., R.11E.; Panoche Hills, along a road to TV-microwave house of Panoche Peak

Str. position: About the middle of Uhalde formation, Panoche group

Fossil: Halymenites sp.

Age: Upper Senonian (s.l.)

Coll.: T. MAtsumoto, $9 / 18 / 1957$

LSJU. $3326[\div 2251]$ [=TM. 2]

Area: Panoche Quad. (1:125000), Fresno Co., W. San Joaquin Valley

Loc.: Approximately 600 feet S., 800 feet W. of NE. corner, sec. 12, T.15S., R.11E.; west slope of Panoche Hills

Str. position: Concretionary sandstone at the top of Uhalde formation, top of Panoche group

Fossil: Glyptoxoceras sp.

Age: Lower Maestrichtian (?) (see LSJU. 2251)

Coll.: M. B. Payne \& T. Matsumoto, $4 / 6 / 1957$

Remarks: LSJU. 3326 is very close to and of the same stratigraphic position as LSJU. 2251

LSJU. 3327 [=TM. 3]

Area: Panoche Quad. (1:125000), Fresno Co., W. San Joaquin Valley

Loc: Approximately 750 feet S., 1500 feet W. of NE. corner, sec. 7, T.15S., R.12E.; west slope of Panoche Hills

Str. position: Limy concretions in Marca shale member of Moreno formation (type area)

Fossils: Baculites cf. rex Anderson, Cymbophora-like shells, etc.

Age: Maestrichtian

Coll.: H. G. Schenck, J. J. Graham, M. B. Payne, \& T. Matsumoto, 4/6/1957

LSJU. 3329 [=TM. 204]

Area: Panoche Quad. (1:125000), Fresno Co., W. San Joaquin Valley

Loc.: 1400 feet S., 1400 feet W. of NE. corner, sec. 7, T.15S., R.12E.; north slope facing Escarpado Canyon, Panoche Hills

Str. position: Marca shale of Moreno formation at its type section (in white limy concretion)

Fossils: Neophylloceras hetonaiense Matsumoto*, Phyllopachyceras sp., Diplomoceras sp., Baculites rex ANDERson*, Inoceramus sp. 
Age: Maestrichtian

Coll.: Max B. Payne \& T. Matsumoto, 9/17/1957

LSJU. 3330 [=TM. 5]

Area: Panoche Quad. (1:125000), Fresno Co., W. Sacramento Valley

Loc.: 200 feet W., 1600 feet S., of NE. corner, sec. 7, T.15S., R.12E.; top of Cima Hill, north of Escarpado Canyon, west side Panoche Hills

Str. position: Cima sand lentil of Dos Palos shale member of Moreno formation, type locality

Fossils: Belemnite-like thing; other shells

Age: Maestrichtian or Paleocene under debate

Coll.: Max B. Payne \& T. Matsumoto, 4/13/1957

Remarks: The belemnite-like specimen was presented to Dr. J. A. JeLETZKY, Geol. Surv. Canada

LSJU. 3335 [ = TM. 211]

Area: New Idria Quad., San Benito Co., W. San Joaquin Valley

Loc.: 2200 feet N., 200 feet E. of SW. corner, sec. 26, T.17S., R.11E.; Larious Creek

Str. position: Lower part of Max B. PAYNE's Kp shale (greenish grey shale unit)

Fossil: Desmoceras (Pseudouhligella) (?) n. sp. (see Matsumoto \& ОватA, 1955, pl. 30, fig. 7)

Age: Turonian (?)

Coll.: Max B. Payne \& T. Matsumoto, 9/20/1957

LSJU. 3336 [=TM. 212]

Area: New Idria Quad., San Benito Co., W. San Joaquin Valley

Loc.: 2500 feet S., 200 feet E. of NW. corner, sec. 26, T.17S., R.11E.; Larious Creek Str. position: Lower part of Max B. PAYNE's Kp shale unit (greenish grey shale with occasional thin bedded s.s.), slightly higher than LSJU. 3335

Fossil: Desmoceras (Pseudouhligella) (?) n. sp. (same as 3335)

Age: Turonian (?)

Coll.: Max B. Payne \& T. Matsumoto, $9 / 20 / 1957$

LSJU. 3337

Area: Priest Valley Quad., Fresno Co., W. San Joaquin Valley

Loc.: 2500 feet N., 500 feet W. of SE. corner, sec. 2, T.21S., R.13E.; Coalinga Hot Springs Canyon, west of conglomerate gorge

Str. position: 10 feet below bentonite bed in shale unit, below Rudistid-bearing conglomerate

Fossil: Desmoceras kossmati Matsumoto*

Age: Lower Cenomanian or Upper Albian

Coll.: S. W. MULLER

LSJU. 3338

Area: Priest Valley Quad., Fresno Co., W. San Joaquin Valley

Loc.: E. 1/2, sec. 2, T.21S., R.13E.; opposite SMITH ranch, Coalinga Hot Springs Canyon (close to LSJU. 3337)

Str. position: 18-20 feet below bentonite, in the same shale unit as LSJU. 3337

Fossil: Puzosia aff. P. subcorbarica Matsumoto

Age: Upper Albian or Lower Cenomanian

Coll.: S. W. MULLER

LSJU. 3339

Area: Priest Valley Quad., Fresno Co., W. Sacramento Valley 
Loc.: NE. $1 / 4$ of SE. $1 / 4$ of sec. 34, T.19S., R.13E.; road cut on SW. side of the highway along Los Gatos Creek

Str. position: Upper Wartham shale equivalent (?)

Fossil: Plesiovascoceras cf. californicum (ANDERSON)

Age: Lower Turonian

Coll.: W. N. BARBAT

LSJU. 3340

Area: Coalinga area, Fresno Co., W. San Joaquin Valley (?)

Loc.: No record (label missing)

Str.position: No record

Fossil: Sciponoceras kossmati (NowAK)

Age: Turonian

Coll.: No record

LSJU. 3341 [=TM. 502]

Area: Coalinga Quad., Fresno Co., W. San Joaquin Valley

Loc.: Approximately center of N. $1 / 2$ of sec. 23, T.21S., R.14E.; road cut, east side of the highway along Warthan Creek, NW. of BM. 924

Str. position: Upper Wartham shale

Fossil: Inoceramus cf. labiatus Schlotheim

Age: Lower Turonian (?)

Coll.: T. MATSUMoto, 4/14/1957

LSJU. 3342 [=TM. 505]

Area: Coalinga Quad., Fresno Co., W. San Joaquin Valley

Loc.: 2500 feet N. and 2200 feet E. of SW. corner, sec. 4, T.20S., R.14E.; road cutting on highway along creek, north side of Los Gatos Creek

Str. position: Calcareous nodules in silty very fine-grained sandstone to fine sandy siltstone, lower part of Ragged Valley shale (so-called Pachydiscus silt)

Fossils: Baculites occidentalis MeEK, Anisomyon (?) sp.

Age: Upper Campanian

Coll.: M. B. Payne \& T. Matsumoto, 9/21/1957

LSJU. 3343B [=TM. 509B]

Area: Coalinga Quad., Fresno Co., W. San Joaquin Valley

Loc.: 150 feet S. and 1700 feet W. of NE. corner, sec. 9, T.20S., R.14E.; south bank of Los Gatos Creek

Str. position: Calcareous nodules in the siltstone of the lower part of Ragged Valley shale

Fossils: Baculites occidentalis Meek, Inoceramus subundatus MeeK

Age: Upper Campanian

Coll:: M. B. Payne \& T. Matsumoto, 9/22/1957

LSJU. 3343C [=TM. 509C]

Area: Coalinga Quad., Fresno Co., W. San Joaquin Valley

Loc.: 100 feet S. and 1750 feet W. of NE. corner, sec. 9, T.20S., R.14E.; south bank of Los Gatos Creek

Str. position: Calcareous concretions in the siltstone of the lower part of Ragged Valley shale

Fossils: Baculites occidentalis MEEK* (abundant), Tetragonites popetensis YABE

Age: Upper Campanian

Coll.: M. B. Payne \& T. Matsumoto, 9/22/1957 
LSJU. 3344

Area: Coalinga Quad., Fresno Co., W. San Joaquin Valley

Loc.: 1500 feet N., 2300 feet E. of SE. corner, sec. 8, T.20S., R.14E.; Post Canyon, just bottom of letter "y" on the map, a branch of Los Gatos Creek

Str. position: About 50 feet above the contact with massive s.s., Ragged Valley shale Fossil: Baculites occidentalis MEEK*

Age: Upper Campanian

Coll.: B. NATERA, 5/8/1954

LSJU. 3345 [ =TM. 507]

Area: Coalinga Quad., Fresno Co., W. San Joaquin Valley

Loc.: 1900 feet S. and 300 feet E. of NE. corner, sec. 9, T.20S., R.14E.; bluff of SE. branch of Los Gatos Creek

Str. position: Ragged Valley shale, calcareous concretions in siltstone

Fossils: Baculites rex ANDERson*, Pachydiscus ootacodensis (STOLICZKA), Hauericeras

(?) sp., Tetragonites popetensis YABE, Inoceramus ef. shikotanensis NAGAO and MATSUMoto

Age: Lower Maestrichtian (?) or uppermost Campanian

Coll.: M. B. Payne \& T. Matsumoto, $9 / 22 / 1957$

LSJU. 3346 [=TM. 506]

Area: Coalinga Quad., Fresno Co., W. San Joaquin Valley

Loc.: 450 feet $\mathrm{N}$. and 2050 feet E. of SW. corner, sec. 3, T.20S., R.14E.; north of Los Gatos Creek

Str. position: Brown Mountain sandstone

Fossil: Baculites cf. rex ANDERson

Coll.: Max B. Payne \& T. Matsumoto, 9/21/1957

LSJU. 3347

Area: Not certain, but possibly Joaquin Rocks Quad., Fresno Co., W. San Joaquin Valley (?) or Hornbrook area, N. California (?)

Loc.: No record of sec., T. and R.; "Black Mountain, a float boulder $1 / 8$ mile of HOFFMASTER's Mountain house"

Str. position: No record

Fossils: Pseudokossmaticeras ef. tchihatcheffi (BöHM), Baculites rex ANDERSON*, other shells

Age: Lower Maestrichtian or uppermost Campanian

Coll.: H. Hannibal \& A. W. Ambrose

Remarks: There are several Black Mountains in California. Some are in the area of Franciscan group, but the matrix of the specimens has no sign of tectonic deformation.

LSJU. 3348

Area: Ventura Co., S. California

Loc.: No record of sec., T. \& R.; "north of Wheeler's Hot Springs, N. W. of Ojai, Ventura Co."

Str.position: No record

Fossils: Pachydiscus (s.l.) sp. [deformed; possibly comparable with P. (s.s.) n. sp. from Alaska or $P$. (Neodesmoceras) catarinae (ANDERson \& HANNA)], Inoceramus sp. [related to $I$. shikotanensis NaGao \& Matsumoto]

Age: Upper Senonian (?)

Coll.: S. W. MulLER 
LSJU. 3349

Area: Black Star Canyon Quad. (7.5 minute), Orange Co., Santa Ana Mts., S. California

Loc.: 600 feet SE., 1400 feet SW. of N. corner of sec. 71 [land lines system within Lomas de Santiago grant]; along a ridge (at elevation 1450 feet) between Fremont and Blind Canyons, on a slope facing the former, north of Irvine Lake

Str. position: Pleasants sandstone

Fossil: Metaplacenticeras cf. pacificum (Sмгтн)

Age: Upper Campanian

Coll.: S. G. S. [Stanford Geol. Surv.] 1950 (under ComptoN)

LSJU. 3350

Area: Black Star Canyon Quad. (7.5 minute), Orange Co., Santa Ana Mts., S. California

Loc.: 700 feet SE., 2200 feet NE. of W. corner of sec. 38 [land lines system within Lomas de Santiago grant]; on a ridge (elevation 890 feet) between Blind Canyon and another smaller canyon to the west of Blind Canyon, closer to that smaller one, north side of Santiago Creek

Str. position: Holz shale member, exact horizon uncertain

Fossil: Baculites boulei Collignon*

Age: Lower Senonian

Coll.: Nisbell, S.G.S. 1950 (under CoMptoN)

LSJU. 3351

Area: Black Star Canyon Quad. (7.5 minutes), Orange Co., Santa Ana Mts., S. California

Loc.: No record of sec. T. \& R.; on ridge west of Baker Canyon, 1 mile from Santiago Canyon

Str. position: Pleasants sandstone

Fossil: Anapachydiscus cf. deccanensis (StoliczKa)

Age: Campanian

Coll.: Belosic, S.G.S. 1950 (under B. M. PAGE)

LSJU. 3352

Area: Santa Monica Mountains, S. California

Loc.: No record of sec., T. \& R.; only "Los Rosas (?)"

Str.position: No record

Age: Maestrichtian (?) or Upper Campanian

Fossil: Pachydiscus (s.s.) cf. subcompressus Matsumoтo

Coll.: NomLand

LSJU. 3353

Area: Coalinga Quad., Fresno Co., W. San Joaquin Valley

Loc.: No record of sec., T. \& R.; just "Coalinga"

Str. position: No record

Fossil: Anapachydiscus cf. californicus (YABE and SHIMIZU)

Age: Upper Senonian

Coll.: W. R. HARMELON

LSJU. 3354

Area: Cholame Quad., Monterey Co.

Loc.: Near the middle of E. line of NE. 1/4, sec. 6, T.24S., R.16E.

Str. position: No record

Fossil: Anapachydiscus cf. arrialoorensis (STOLICZKA) 
Age: Campanian

Coll.: C. R. Swarts, Sept. 1919

Remarks: The locality record is doubtful, since "Coalinga", which is far from sec. 6, T.24S., R.16E., is indicated on one of the labels, in addition to this sec. T. \& R.

LSJU. 3355

Area: Panther Spring Quad., Tehama Co., E. Sacramento Valley

Loc.: SE. 1/4, sec. 24, T.27N., R.1E.; Mill Creek, near sulphur springs, 1000 feet north of "Pape Place", on ranch of "Arthur BANTA"

Str. position: A small exposure of Cretaceous mudstone, surrounded by Cenozoic volcanic rocks

Fossils: Canadoceras yokoyamai (Јімво)*, Canadoceras n. sp. (?) aff. C. hoepeni CoLligNon, Hauericeras cf. angustum $\mathrm{Y}_{\mathrm{ABE}}$, Glyptoxoceras sp., Tetragonites sp., Inoceramus naumanni YokоYAMA, other mollusks

Age: Uppermost Santonian or Lower Campanian

Coll.: S. W. MILLER

LSJU. 3356 [=TM. 701]

Area: Tesla Quad., Alameda Co., Bay Area

Loc.: Near the middle of E. line of sec. 27, T.2S., R.3E.; "Redmont cut" of Western Pacific railroad, about $1 / 3$ mile SEE. of the bridge over US. highway $50[\div$ Loc. XIII of HUEY (1948) ]

Str. position: A unit of shale with frequently interbedded, sandstone. The Cretaceous of this area has not been well subdivided. The collections from this large exposure are subdivided into $a, b, c, d$ in ascending order.

Fossils: Submortoniceras sp. (?), Baculites cf. chicoensis Trask, Pachydiscus ef. neevesi Whiteaves, Exiteloceras (?) sp.

Age: Campanian

Coll.: H. G. Schenck, J. J. Graham, D. L. Jones, \& T. Matsumoto, 12/12/1957

LSJU. 3357 [=TM. 702]

Area: Tesla Quad., Alameda Co., Bay area

Loc.: NW. 1/4 of SE. 1/4, sec 11, T.4S., R.2E.; “Old JoRDAN ranch", Arroyo del Valle, northeast side of Creek on the level of the Creek (This is close to LSJU. 2732 and loc. $\mathrm{X}$ of HUEY (1948), which are at different levels.)

Str. position: Calcareous part in massive sandstone unit in the higher part of the Cretaceous exposed in the area (3357 is probably higher than 2732)

Fossil: Baculites rex ANDERSON

Age: Maestrichtian

Coll.: D. L. Jones, H. G. Schenck, J. J. Graham, \& T. Matsumoto, 12/12/1957

LSJU. 3358

Area: Lost Hills Quad. (1:125000), Kern Co., S. San Joaquin Valley

Loc.: 1250 feet S., 2250 feet E. of NW. corner, sec. 12, T. 28S., R.18E.

Str. position: No record on the label

Fossil: Baculites rex ANDERson

Age: Maestrichtian or Upper Campanian

Coll.: No record

LSJU. 3359

Area: Coalinga Quad., Fresno Co., W. San Joaquin Valley

Loc.: 300 feet N., 900 feet E. of SE. corner, sec. 5, T.20S., R.14E.; N. side of Alcalde Hills, facing Los Gatos Creek

Str. position: Labelled as "Joaquin Rock s.s.", but doubtful 
Fossil: Baculites rex ANDERSON

Age: Maestrichtian or Upper Campanian

Coll.: S. W. MULLER \& Students

LSJU. 3360

Area: Panoche Quad. (1:125000), Fresno Co., W. San Joaquin Valley

Loc.: No record of sec., T. \& R.; middle of Redil Canyon, W. side Panoche Hills

Str. position: A boulder or contemporaneous reworked concretion in Papanatas conglomerate, Panoche group

Fossil: Leconteites lecontei (ANDERSON)

Age: Middle Albian

Coll.: D. L. JoNES

LSJU. 3361 [=TM. 106]

Area: Panoche Quad. $(1: 125000)$, Fresno Co., W. San Joaquin Valley

Loc.: 1150 feet E., 600 feet S. of NW. corner, sec. 24, T.14S., R.10E.; Papanatas Canyon, west side of the Panoche Hills

Str. position: A boulder or reworked contemporaneous concretion in the middle part of Papanatas conglomerate, Panoche group

Fossils: Beudanticeras (?) sp., a few other shells

Age: Albian (?)

Coll.: T. Matsumoto, 4/10/1957

LSJU. 3362

Area: Orestimba Quad., Stanislaus Co., W. San Joaquin Valley

Loc.: No record of sec., T. \& R.; "Little Salado Canyon"

Str. position: No record (lithologically similar to LSJU. 3363)

Fossil: Eubaculites cf. ootacodensis (SToLICZKA)

Age: Maestrichtian (?)

Coll.: "R. \& W. \& D." (on a label of Cal. Inșt. Tech.)

LSJU. 3363

Area: Orestimba Quad., Stanislaus Co., W. San Joaquin Valley

Loc.: No record of sec., T. \& R.; "Little Salado Canyon" (?)

Str. position: No record of formational name; " 1500 feet E. of vertebr. loc. \#380 [field number ?] and about 200 feet stratigraphically higher; in large concretion"

Fossil: Eubaculites cf. ootacodensis (SToLICZKA)

Age: Maestrichtian (?)

Coll.: “R. M. L. 12/13/1940" (on a label of Calif. Inst. Tech.)

LSJU. 3364

Area: Orestimba Quad., Stanislaus Co. (?), W. San Joaquin Valley

Loc.: No record of sec., T. \& R.; "near loc. \#380 [field number] presumably in or near Little Salado Canyon"

Str. position: No record of formational name; "about 250 feet stratigraphically from \#380"

Fossils: Pachydiscus cf. subcompressus obsoletus Matsumoto

Age: Maestrichtian (?)

Coll.: “R. M. L. 12/16/1940"

LSJU. 3365

Area: Orestimba Quad., Stanislaus Co. (?), W. San Joaquin Valley

Loc.: No record of sec., T. \& R.; "north of Reptile Ridge", float

Str. position: No record of formational name; "about horizon of $\# 336$ [field number ?]" 
Fossil: Pachydiscus cf. subcompressus obsoletus MATSUмото

Age: Maestrichtian (?)

Coll.: “A.B.D. 7/16/1939" (on a label of Calif. Inst. Tech.)

SOC. K-35

Area: Millville Quad. (Redding area), Shasta Co., NE. Sacramento Valley

Loc.: Extreme east central part of sec. 4, T.32N., R.3W.; 300 to 700 feet south of Redding-Alturas highway (299) in small ravine. Reference to old highway. About 3/8 mile east of line of section

Str. position: Member II or PoPENoE

Fossil: Romaniceras (?) sp.

Age: Turonian

Coll.: KenNeLl \& RoBINS

SOC. K-39

Area: Millville Quad. (Redding area), Shasta Co., NE. Sacramento Valley

Loc.: Sec. 3, T. 32N., R.3W.; Salt Creek, extreme west and south central part of sec. 3 or west bank of Salt Creek, several hundreds feet above confluence with Little Cow Creek

Str. position: Member II of PoPenoe

Fossil: Hyphantoceras sp.

Age: Turonian-Santonian; Turonian for Member II

Coll.: KenNeLL \& RoBins

SOC. $\mathrm{K}-40$

Area: Millville Quad. (Redding area), Shasta Co., NE. Sacramento Valley

Loc.: Extreme north central part of sec. 4, T.32N., R.3W.; Yank Creek, where creek has nearly east-west trend for about 1500 feet; approximately 1/2 mile north of Redding-Alturas highway

Str. position: Member II of PoPENoE, 12 feet above K-41

Fossil: Tetragonites glabrus (Јімво)

Age: Turonian-Santonian; Turonian for Member II

Coll.: KenNell \& Robins

SOC. $\mathrm{K}-41$

Area: Millville Quad. (Redding area), Shasta Co., NE. Sacramento Valley

Loc.: Extreme north central part of sec. 4, T. 32N., R.3W.; Yank Creek, where creek has nearly E-W trend for about 1500 feet; about $1 / 2$ mile $\mathrm{N}$. of Redding-Alturas highway

Str. position: Member II

Fossils: Eucalycoceras (?) shastense (REAGAN)*, Tetragonites cf. glabrus (JIMBo)

Age: Turonian

Coll.: KenNell \& RoBins

SOC. $\mathrm{K}-42$

Area: Millville Quad. (Redding area), Shasta Co., NE. Sacramento Valley

Loc.: South-central part of sec. 4, T.32N., R.3W.; in small north-south tributary to Little Cow Creek, $3 / 8$ to $1 / 2$ mile south of Redding-Alturas highway

Str. position: Member II

Fossil: Subprionocyclus sp. (?)

Age: Upper Turonian

Coll.: KenNelL \& Robins, 9/21/1951 
SOC. $\mathrm{K}-43$

Area: Millville Quad. (Redding area), Shasta Co., NE. Sacramento Valley

Loc.: South central part of sec. 4, T.32N., R.3W.; in small north-south tributary to Little Cow Creek; $3 / 8$ to $1 / 2$ mile south of Redding-Alturas highway

Str. position: Member II

Fossil: Mesopuzosia sp.

Age: Turonian

Coll:: KeNNELL \& ROBINS

SOC. K-44

Area: Millville Quad. (Redding area), Shasta Co., NE. Sacramento Valley

Loc.: Extreme north and west central part of sec. 16, T.32N., R.3W.; Little Cow Creek, east bank approximately 2000 feet almost due south of WiLliams residence Str. position: Member III of POPENOE

Fossils: Subprionocyclus normalis (ANDERSoN), Scaphites sp.

Age: Upper Turonian

Coll.: KeNNEL \& ROBINS

SOC. K-46

Area: Millville Quad. (Redding area), Shasta Co., NE. Sacramento Valley

Loc.: Extreme west central part sec. 5, T.32N., R.3W.; in high bank of Dry Creek within $1000 \pm$ feet (upstream) of Dry Creek county road

Str. position: Member II

Fossil: Scaphites pittensis ANDERSON

Age: Turonian

Coll.: KENNEL \& ROBINS

SOC. K-50

Area: Millville Quad. (Redding area), Shasta Co., NE. Sacramento Valley

Loc.: Along the line dividing sec. 4 and 5, T.32N., R.2W.; upper Swede Creek, where creek has N-S trend

Str. position: Member II or III

Fossil: Hyphantoceras sp.

Age: Turonian

Coll: : KENNEL \& RoBins, 10/8/1951

SOC. K-53

Area: Millville Quad. (Redding area), Shasta Co., NE. Sacramento Valley

Loc.: Approximately 100 feet S. of NE. corner sec. 16, R.32N., R.2W.; on north bank of Oak Run Creek, where a small tributary flows into Oak Run Creek; Rodgers Gulch meets Oak Run Creek about 500 feet above here

Str. position: Member IV of PoPENOE; lower than K-54 and higher than K-55

Fossils: Eupachydiscus aff. E. teshioensis (JIMво), Hauericeras sp.

Age: Coniacian (?)

Coll.: KenNell \& Robins, 10/9/1951

SOC. K-54

Area: Millville Quad. (Redding area), Shasta Co., NE. Sacramento Valley

Loc.: SE. corner, sec. 9, T.32N., R.2W.; on the same small tributary as loc. K-53, about 400 feet NW. of Oak Run Road

Str. position: Member IV of PoPENOE

Fossils: Eupachydiscus aff. E. teshioensis (Јімво), Hauericeras (?) sp., Hyphantoceras sp., Inoceramus ef. cordiformis SOWERBY, Inoceramus aff. I. naumanni YOKOYAMA 
Age: Coniacian (?)

Coll.: KenNell \& RoBINS, 10/9/1951

SOC. $\mathrm{K}-69$

Area: Lodoga Quad., Colusa Co., W. Sacramento Valley

Loc.: Near center of east line of sec. $32, T .18 \mathrm{~N}$., R.4W.; just north of small pass across Logan Ridge, on west flank of hill

Str. position: In shale, apparently about 35 feet below Venado sandstone

Fossil: Plesiovascoceras californicum (ANDERSON)

Age: Lower Turonian

Coll.: M. V. KIRK, $12 / 26 / 1951$

SOC. K-70

Area: Lodoga Quad., Colusa Co., W. Sacramento Valley

Loc.: Center of S. half of E. line of sec. 32 , T.18N., R.4W.; about half way up west face of hill of Logan Ridge, in second gully, S. of pass

Str. position: In limestone concretions; numerous pebbles up to 2 inches diameter scattered through shales at this locality. About 50 feet stratigraphically below Venado sandstone

Fossils: Desmoceras (Pseudouhligella) cf. dawsoni Whiteaves, Pachydesmoceras cf. colusaense (ANDERSON), Beudanticeras cf. haydeni (GABB), Mortoniceras (Deiradoceras) sp. (allied to the one from K-102), Pseudohelicoceras petersoni (ANDERSON)

Age: Upper Albian

Coll.: M. V. KIRK

SOC. $\mathrm{K}-72$

Area: Lodoga Quad., Colusa Co., W. Sacramento Valley

Loc.: Just west of center of north half of the east line of sec. 32, T.18N., R.4W.; in first large gully north of pass

Str. position: From contorted area of limestone concretions about 50 feet below sandstones

Fossil: Pachydesmoceras colusaense (ANDERSON)

Age: Upper Albian

Coll.: M. V. KIRK

SOC. K-73

Area: Rumsey Quad., Colusa Co., SW. Sacramento Valley

Loc.: Just SE. of center of SE. 1/4 of NE. 1/4 of sec. 7, T.13N., R.3W.; in cut of stream just upstream from DoBBINS ranch house in horizon of limestone concretions, Sand Creek

Str. position: Forbes formation (basal part)

Fossils: Patagiosites arbucklensis (ANDERSON), Inoceramus cf. schmidti MICHAEL, Inoceramus sp. (flat large form)

Age: Campanian

Coll.: M. V. KIRK, 12/27/1951

SOC. K-74

Area: Rumsey Quad., Colusa Co., SW. Sacramento Valley

Loc. SE. $1 / 4$ of NE. $1 / 4$ of sec. 7, T.13N., R.3W.; about 200 feet east of loc. K-73, float in Sand Creek near Gorrill Gas wells

Str. position: Probably derived from basal Forbes formation

Fossil: Patagiosites arbucklensis (ANDERSON)

Age: Campanian

Coll.: M. V. KIRK, 12/27/1951 
SOC. K-75

Area: Rumsey Quad, Colusa Co., SW. Sacramento Valley

Loc.: Just south of center of NE. $1 / 4$ of sec. 7, T.13N., R.3W.; in stream canyon over ridge to north of loc. K-74 about the same horizon, Sand Creek area

Str. position: Forbes formation (basal part)

Fossil: Inoceramus cf. schmidti MichaEL (fragment)

Age: Campanian (?)

Coll.: M. V. KIRK

SOC. K-82

Area: Coalinga Quad., Fresno Co., W. San Joaquin Valley

Loc.: Center of sec. 4, T.20S., R.14E.; just east of road cut on north side of road along Los Gatos Creek; in calcareous concretions in siltstone [ $\doteqdot$ TM. 505]

Str. position: Ragged Valley shale or "Pachydiscus silt"

Fossils: Anapachydiscus sp. juv. [of the group of A. arrialoorensis (SToLICZkA)], Baculites occidentalis MEEK

Age: Upper Campanian

Coll.: M. V. KIRK, 3/26/1952

SOC. $\mathrm{K}-85$

Area: Joaquin Rocks Quad., Fresno Co., W. San Joaquin Valley

Loc.: Approximately in center of SW. 1/4, sec. 7, T.19S., R.15E.; on the south spur of Black Mountain just east of the head of Oil Canyon

Str. position: Ragged Valley shale, about 75 feet stratigraphically above contact with Joaquin Ridge sandstone

Fossil: Pachydiscus sp. indet. [a fragment of a smoothish outer whorl, which is still septate]

Age: Upper Senonian

Coll.: M. V. KIRK, $3 / 27 / 1952$

SOC. K-86

Area: Joaquin Rocks Quad., Fresno Co., W. San Joaquin Valley

Loc.: Just east of center of $1 / 4$ SE. of sec. 23, T.19S., R.14E.; in limestone float in deep gully

Str. position: Probably derived from the Ragged Valley shale above Joaquin Ridge sandstone

Fossil: Pachydiscus sp. [inner whorl, comparable to $P$. neevesi Whiteaves or $P$. buckhami UsHER, characterized by distant, narrow ribs with bullate tubercles]

Age: Upper Senonian

Coll.: M. V. KIRK, 3/27/1952

SOC. K-101

Area: Ono Quad., Shasta Co., NW. Sacramento Valley

Loc.: SE. $1 / 2$, NE. $1 / 4$, sec. 17 , T.30N., R.6W.; about 200 yards upstream from confluence of Huling Creek and North Fork of Cottonwood Creek

Str. position: About 10 feet stratigraphically above the first conglomerate in Huling Creek

Fossils: Desmoceras (Pseudouhligella) cf. dawsoni WhIteAves, Lechites aff. L. gaudini (PICTET and CAMPICHE)*

Age: Upper Albian (?) (possibly Lower Cenomanian)

Coll.: M. V. KIRK, 4/16/1952

SOC. K-102

Area: Ono Quad., Shasta Co., NW. Sacramento Valley 
Loc. \& Str. position: From matrix of conglomerate just upstream on Huling Creek from loc. 101 ; sec. 17 , T.30N., R.6W.

Fossils: Beudanticeras haydeni (GABB), Pachydesmoceras colusaense (ANDERSON), Mortoniceras (Deiradoceras) sp. (comparable with the one from loc. 70)

Age: Upper Albian

Coll.: M. V. KIRK, 4/16/1952

SOC. $\mathrm{K}-103$

Area: Ono Quad., Shasta Co., NW. Sacramento Valley

Loc.: About $1 / 4$ mile upstream from loc. 102 in first gully on east bank of Huling Creek at a point about 10 feet upstream from first side gully

Fossil: Desmoceras sp. immature of latidorsatum group

Age: Upper Albian (?)

Coll.: M. V. KIRK, 4/16/1952

SOC. $\mathrm{K}-108$

Area: Ono Quad., Shasta Co., NW. Sacramento Valley

Loc. \& Str. position: Sec. 17, T.30N., R.6W.; probably float in stream tributary to Huling Creek just upstream from sandstone bed just upstream from loc. 107, at a point about 400 feet east (upstream) of mouth of tributary stratigraphically above sandstone bed

Fossil: Neophlycticeras (?) sp. (relatively large outer whorl) (All the hitherto described specimens of Neophylycticeras are small. It is interesting to see a specimen of this large size in Calif.)

Age: Upper Albian (?)

Coll.: M. V. KIRK

SOC. K-114

Area: Ono Quad., Shasta Co., NW. Sacramento Valley

Loc.: Sec. 17, T.30N., R.6W.; about $1 / 4$ mile upstream on east fork of Huling Creek from mouth of west branch

Fossil: Tetragonites n. sp. (?) aff. T. kiliani $\mathrm{J}_{\mathrm{ACOB}}$

Age: Albian

Coll.: M. V. KIRK

SOC. K-129

Area: Ono Quad., Shasta Co., NW. Sacramento Valley

Loc.: In small box-like canyon on east bank of Huling Creek, about $1 / 4$ mile upstream from the mouth of the east fork. Lithologically similar to loc. 114, ANDERson's "neptune zone"

Str. position: No record

Fossils: Desmoceras merriami ANDERSON, Beudanticeras [Brewericeras ?] haydeni (GABB), Brewericeras breweri (GABB), Douvilleiceras cf. restitutum ANDERson, Tetragonites n. sp. (?) (allied to T. kiliani $\mathrm{J}_{\mathrm{ACOB}}$ )

Age: Albian

Coll.: M. V. KIRK, 4/21/1952

SOC. K-178

Area: Chico Quad. $(1: 125000)$, Butte Co., E. Sacramento Valley

Loc.: Sec. 13, T.23N., R.2E.; in road cut just behind BICKLEY's cabin along old road apparently leading up to "14-mile house"; about 5.5 miles by road from " 10 -mile house"

Str. position: Chico formation (s.s.)

Fossil: Baculites capensis Woons 
Age: Santonian

Coll.: M. V. KIRK, 5/27/1952

SOC. K-179 [=UC. A-4654]

Area: Chico Quad. (1:125000), Butte Co., E. Sacramento Valley

Loc.: Sec. 14, T.23N., R.2E.; in Chico Creek, north bank just upstream from south boundary of sec. 14 ; at a point about 4.4 miles by road from "Ten-mile house"

Str. position: Chico formation (s.s.)

Fossils: Submortoniceras chicoense (TRASK), Baculites chicoensis Trask

Age: Campanian

Coll.: M. V. KIRK, 5/28/1952

SOC. K-180

Area: Chico Quad. (1:125000), Butte Co., E. Sacramento Valley

Loc.: Sec. 23, T.23N., R.2E.; on east bank of Chico Creek, about 4 miles by road from "Ten-mile house" and 0.4 mile by road downstream from loc. 179, just under bank at north end of first meadow downstream from 179

Str. position: Chico formation (s.s.)

Fossils: Submortoniceras chicoense (TRASK), Baculites chicoensis TRASK

Age: Campanian

Coll.: M. V. KIRK

SOC. K-181

Area: Chico Quad. (1:125000), Butte Co., E. Sacramento Valley

Loc.: Sec. 23, T.23N., R.2E.; west bank of Chico Creek, about 0.2 mile upstream from loc. $\mathrm{K}-180$

Str. position: Chico formation (s.s.)

Fossil: Baculites chicoensis Trask

Age: Campanian

Coll.: M. V. KIRK, 5/28/1952

SOC. K-182

Area: Chico Quad. (1:125000), Butte Co., E. Sacramento Valley

Loc.: Sec. 26, T.23N., R.2E.; "Salt Springs" on west bank of Chico Creek, at a point about 2.9 miles (by road) from "Ten-mile house"

Str. position: Chico formation (s.s.)

Fossils: Baculites chicoensis TRASK, Inoceramus sp. (a large form with moderate inflation on the main part of the flank, apparently intermediate from $I$. inconstans Woods to I. expansus BAILEY-I. ezoensis YokoYAMA)

Age: Campanian

Coll.: M. V. KIRK, 5/28/1952

SOC. K-185

Area: Chico Quad. (1:125000), Butte Co., E. Sacramento Valley

Loc.: No record of sec., T. \& R.; Butte Creek, about 1 mile downstream from Centerville bridge; material dug up in excavation for ditch; reached from end of second dirt road downstream from Centerville bridge

Str. position: Chico formation (s.s.)

Fossil: Baculites chicoensis Trask

Age: Campanian

Coll.: M. V. KIRK, 5/30/1952

SOC. K-186

Area: Oroville Quad., Butte Co., E. Sacramento Valley 
Loc.: Sec. 25, T.21N., R.3E.; near Pentz, about 1.4 mile downstream from bridge on Oroville-Pentz road in bluffs on north bank of Dry Creek

Str. position: Chico formation (s.s.)

Fossil: Baculites chicoensis Trask

Age: Campanian

Coll.: M. V. KIRK, 5/30/1952

SOC. K-187

Area: Ono Quad., Shasta Co., NW. Sacramento Valley

Loc.: NW. $1 / 4$, SW. $1 / 4$, sec. 16 , T.30N., R.6W.; on the northeast bank of the North Fork of Cottonwood Creek, about $1 / 4$ mile below dam

Str. position: In silty sandstone and conglomerate just under another conglomerate at point where valley starts to widen out downstream

Fossils: Desmoceras (Pseudouhligella) cf. barryae (ANDERSon), Neophylloceras cf. seresitense (PERVINQUIÈRE)

Age: Cenomanian

Coll.: M. V. KIRK, 6/25/1952

Remarks: This locality may be close to CAS. 2233

SOC. K-187F

Area: Ono Quad., Shasta Co., NW. Sacramento Valley

Loc.: Near extreme southeast corner of sec. 17; on the northeast bank of the North Fork of Cottonwood Creek about 1/4 mile below dam

Str. position: In silty sandstone and conglomerate just under prominent conglomerate at point where valley starts to widen out downstream

Fossils: Desmoceras (Pseudouhligella) barryae ANDERSon, with many other wellproserved shells

Age: Cenomanian (?)

Coll.: M. V. KIRK, $6 / 25 / 1952$

SOC. K-190F

Area: Ono Quad., Shasta Co., NW. Sacramento Valley

Loc.: Just south of the middle of the north line of sec. 2, T.29N., R.7W.; about 1000 feet (direct line) up first south tributary of Roaring River, upstream from conglomerate. This tributary joints Roaring River at the southwest part of a large circular meander in Roaring River.

Str. position: No formational name

Fossils: Desmoceras cf. kossmati Matsumoto iconstrictions better marked than the Japanese types), Graysonites cf. wooldridgei Young

Age: Lower Cenomanian

Coll.: M. V. KIRK, 6/26/1952

SOC. K-191

Area: Ono Quad., Shasta Co., NW. Sacramento Valley

Loc.: Sec. 2, T.29N., R.7W.; in gully on north side of tributary of loc. K-190, about 1000 feet upstream from loc. K-190

Fossil: A poorly preserved fragment, comparable to Graysonites sp.

Age: Lower Cenomanian (?)

Coll.: M. V. KIRK, 6/26/1952

SOC. $\mathrm{K}-192 \mathrm{~F}$

Area: Ono Quad., Shasta Co., NW. Sacramento Valley

Loc.: NE. $1 / 4$, sec. 3, T.29N., R.7W.; float in stream bed about 900 feet west and somewhat south of loc. K-191, in the base of " $U$ " shaped meander, Roaring River 
Fossil: Graysonites cf. wooldridgei Young

Age: Lower Cenomanian

Coll.: M. V. KIRK, 6/26/1952

SOC. K-193A

Area: Ono Quad., Shasta Co., NW. Sacramento Valley

Loc.: S. $1 / 2$ of NE. $1 / 4$, sec. 3 , T.29N., R.7W.; first south tributary of Roaring River, about 100-150 feet west of loc. K-193, in south bank of stream

Fossil: Graysonites wooldridgei YounG*

Age: Lower Cenomanian

Coll.: M. V. KIRK, 6/26/1952

SOC. K-194

Area: Ono Quad., Shasta Co., NW. Sacramento Valley

Loc.: SE. $1 / 4$, SW. $1 / 4$, sec. 35, T.30N., R.7W.; about 1300 feet west of north of mouth of the first south tributary, in south bank of Roaring River; about 3000 feet slightly south of NW. from the conglomerate on Roaring River

Fossil: Desmoceras (Pseudouhligella) cf. dawsoni (WhIteAves) (immature)

Age: Albian

Coll.: M. V. KIRK, 6/27/1952

SOC. $\mathrm{K}-197$

Area: Ono Quad., Shasta Co., NW. Sacramento Valley

Loc.: NW. $1 / 4$, SW. $1 / 4$ of sec. 35, T.30N., R.7W.; about 750 feet upstream from loc. K-196, in small gully on north bank of Roaring River, just upstream from gully on south bank

Fossil: Beudanticeras sp. (probably B. haydeni (GABB))

Age: Albian

Coll.: M. V. KIRK, $6 / 27 / 1952$

SOC. K-199

Area: Chico Quad. $(1: 125000)$, Butte Co., E. Sacramento Valley

Loc.: No record of sec., T. \& R.; Little Chico Creek, from outcrop in south bank of Little Chico Creek about 150 feet below fence at first portion of steep bank

Str. position: Chico formation (s.s.)

Fossils: Submortoniceras chicoense (TRASK), S. sp. (smooth form), Baculites chicoensis TRASK

Age: Campanian

Coll.: M. V. KIRK, 6/28/1952

SOC. K-200

Area: Ono Quad., Tehama Co., NW. Sacramento Valley

Loc.: NW. 1/4, SW. 1/4, sec. 12, T.28N., R.7W.; about 9150 feet upstream on Dry Creek from junction of Salt Creek and Dry Creek on road from Red Bluff to Beegum; just downstream (about 50 feet) from first gully in the first outcrop of Cretaceous on the north bank of Dry Creek

Fossils: Puzosia (?) or Mesopuzosia (ribs weathered) (K-200A), Collignoniceras or Subprionocyclus indet. (small, immature)

Age: Turonian

Coll.: M. V. KIRK, 6/29/1952

SOC. K-201

Area: Ono Quad., Tehama Co., NW. Sacramento Valley

Loc: : NE. $1 / 4$, SE. $1 / 4$, sec. 11, T.28N., R.7W.; about 550 feet upstream from loc. K-200 on north bank of Dry Creek 
Str. position: No formational name

Fossil: Collignoniceras (?) sp. immature

Age: Turonian

Coll.: M. V. KIRK, 6/29/1952

SOC. K-202

Area: Ono Quad., Tehama Co., NW. Sacramento Valley

Loc.: NW. $1 / 4$, SE. $1 / 4$, sec. 11 , T.28N., R.7W.; from northwest end of meander of Dry Creek which starts at loc. K-201 on same side of Dry Creek about 25 feet downstream steeper bank

Fossil: Collignoniceras sp. immature [A number of specimens in silty fine sandstone or fine sandy siltstone, comparable to the immature shells of C. woollgari (MANTELL) ]

Age: Turonian

Coll.: M. V. KIRK, 6/24/1952

SOC. K-203

Area: Ono Quad., Tehama Co., NW. Sacramento Valley

Loc.: SW. $1 / 4$, SE. $1 / 4$, sec. 11, T.28N., R.7W.; near eastern, downstream end of large outcrop on south bank of Dry Creek downstream from loc. 202

Fossil: Collignoniceras sp. allied to or possibly identical with C. woollgari (MANTELL)

Age: Turonian

Coll.: M. V. KIRK, 6/29/1952

SOC. $\mathrm{K}-204$

Area: Ono Quad., Shasta Co., NW. Sacramento Valley

Loc.: NE. $1 / 4$ of NE. $1 / 4$, sec. 2, T.29N., R.7W.; about 600 feet upstream from the conglomerate on the north bank of Roaring River in small cut bank

Fossil: Desmoceras ef. kossmati Matsumoto

Age: Lower Cenomanian (?)

Coll.: M. V. KIRK, 6/30/1952

SOC. K-205

Area: Ono Quad., Shasta Co., NW. Sacramento Valley

Loc.: Sec. 1, T.29N., R.7W.; from first outcrop on right side (south) of Roaring River, downstream from conglomerate. The outcrop is just next to road at sharp " $U$ " bend of the river.

Fossils: Marshallites $n$. sp. (an involute and finely ribbed species same as an undescribed $n$. sp. from the Cenomanian of Japan), Sciponoceras cf. baculoide (MANTELL) *

Age: Cenomanian

Coll.: M. V. KIRK, 6/30/1952

SOC. K-206

Area: Ono Quad., Shasta Co., NW. Sacramento Valley

Loc.: Near center of W. $1 / 2$ of SW. $1 / 4$ of sec. 1, T.29N., R.7W.; in steep gully behind coral at head of cut-off " $U$ " bend in Roaring River

Fossils: Desmoceras (Pseudouhligella) cf. japonicum YABE, Anagaudryceras sp., Zelandites cf. inflatus MATSUMото, Sciponoceras sp.

Age: Cenomanian

Coll.: M. V. KIRK, 6/30/1952

SOC. K-209

Area: Ono Quad., Shasta Co., NW. Sacramento Valley 
Loc.: Approximately 2200 feet N. and 1100 feet W. of SE. corner, sec. 1, T.29N., R.7W.; SW. bank of Roaring River

Fossils: Kanabiceras septemseriatum (CRAGIN)*, Mammites (?) sp., Plesiovascoceras californicum (ANDERSON)*, Mesopuzosia sp. indet.

Age: Lower Turonian

Coll.: M. V. KIRK, 6/30/1952

SOC. $\mathrm{K}-210$

Area: Ono Quad., Shasta Co., NW. Sacramento Valley

Loc.: Sec. 12, T.29N., R.7W.; Roaring River; from limestone concretion just inside and uphill from the gate across the road leading to the MCAULTIE ranch

Fossil: Puzosia intermedia orientalis MATSUMoto*

Age: Turonian (probably lower part)

Coll.: M. V. KIRK, 6/30/1952

SOC. K-211

Area: Ono Quad., Shasta Co., NW. Sacramento Valley

Loc.: SE. $1 / 4$, SE. $1 / 4$, sec. 1, T.29N., R.7W.; Roaring River, at the head of the easternmost gully just downstream and over the fence to the south of loc. K-209

Fossils: Puzosia intermedia orientalis Matsumoto, Mammites (?) sp.

Age: Lower Turonian

Coll.: M. V. KIRK, $7 / 1 / 1952$

SOC. K-212

Area: Ono Quad., Shasta Co., NW. Sacramento Valley

Loc.: SW. $1 / 4$, SE. $1 / 4$, sec. 6, T.29N., R.6W.; on southeast bank of Roaring River, about 3000 feet downstream from Pope ranch house, from big outcrop of thinly bedded sandstone and shale

Fossils: Subprionocyclus sp. (immature) (many smaller specimens in a sandstone), Mesopuzosia sp. indet. [may be comparable with $M$. indopacifica (Kossmat)]

Age: Upper Turonian

Coll.: M. V. KIRK, 7/1/1952

SOC. K-213

Area: Ono Quad., Shasta Co., NW. Sacramento Valley

Loc.: 500 feet W. of SE. corner on S. line of sec. 5, T.29N., R.6W.; north bank of Roaring River, about 2800 feet downstream from loc. K-212 at east end of large cut bank at a point about halfway from a sandstone dike to the end of outcrop. This is the last good outcrop before the Tertiary.

Fossils: Pachydesmoceras cf. pachydiscoide Matsumoto, Inoceramus sp. (cf. I. hobetsensis Nagao \& Matsumoto)

Age: Turonian

Coll.: M. V. KIRK, 7/1/1952

SOC. K-220

Area: Millville Quad. (Redding area), Shasta Co., NE. Sacramento Valley

Loc.: SE. $1 / 4$ of SW. $1 / 4$, sec. 4, T.32N., R.2W.; boulders in creek bed about 200 feet upstream from E-W trending fence just upstream from road, which intersects Swede Creek at a point about 2 miles from Oak Run road (Wilkinson school)

Str. position: No record; presumably Member IV

Fossil: Baculites schencki Matsumoto

Age: Coniacian

Coll.: M. V. KIRK, 6/7/1952 
SOC. $\mathrm{K}-221$

Area: Millville Quad. (Redding area), Shasta Co., NE. Sacramento Valley

Loc.: No record of sec., T. \& R.; "in cut of Swede Creek just downstream from fence of loc. K-220 at a point about 300 feet upstream from road near lone poplar trees

Str. position: Member IV of Popenoe, but doubtful

Fossil: Subprionocyclus neptuni (GEINITZ)*

Age: Upper Turonian

Coll.: M. V. KIRK, 7/17/1952

SOC. K-224

Area: Millville Quad. (Redding area), Shasta Co., NE. Sacramento Valley

Loc.: From next bank downstream from loc. K-223, about 20 feet downstream from fence, Swede Creek

Str. position: Member IV of PoPENOE, but doubtful

Fossil: Romaniceras cf. deverioide (DE GROSSOUVRE)

Age: Turonian

Coll.: M. V. KIRK, 7/18/1952

SOC. $\mathrm{K}-225$

Area: Millville Quad. (Redding area), Shasta Co., NE. Sacramento Valley

Loc.: No record of sec., T. \& R.; Swede Creek, from banks in next curve of stream downstream from K-224; about 150 feet south of fence

Str. position: Member IV of POPENOE, but doubtful

Fossils: Romaniceras deverioide (DE GROSSOUVRE)*

Age: Turonian

Coll.: M. V. KIRK, 7/18/1952

SOC. K-226

Area: Millville Quad. (Redding area), Shasta Co., NE. Sacramento Valley

Loc.: No record of sec., T. \& R.; Swede Creek, about 100 yards downstream from loc. $\mathrm{K}-225$ in creek bottom

Str. position: PoPENOE's Member IV, but doubtful

Fossils: Subprionocyclus cf. neptuni (GeINITZ), Romaniceras sp. (deformed, immature)

Age: Turonian

Coll.: M. V. KIRK, 7/18/1952

SOC. K-227

Area: Millville Quad. (Redding area), Shasta Co., NE. Sacramento Valley

Loc.: No record of sec., T. \& R.; Swede Creek, about 400 feet downstream from loc. 226 on east bank of Swede Creek

Str. position: POPENOE's Member IV, but doubtful

Fossil: Coilopoceras (?) sp. or Hoplitoides sp. (a crushed specimen, showing sutures)

Age: Turonian or Coniacian

Coll.: M. V. KIRK

SOC. K-228

Area: Millville Quad. (Redding area), Shasta Co., NE. Sacramento Valley

Loc.: No record of sec., T. \& R.; Clover Creek, about 1.5 miles east of Millville at the end of district road north of cut off from Whitmore road in south bank of Clover Creek, about 250 feet \pm downstream from dam

Str. position: Member IV of POPENOE

Fossil: Damesites cf. sugata (ForBes)

Age: Lower Senonian

Coll.: M. V. KIRK, 7/18/1952 
SOC. K-229 [\% CIT. 1249]

Area: Millville Quad. (Redding area), Shasta Co., NE. Sacramento Valley

Loc.: NE. $1 / 4$ of SE. $1 / 4$ of sec. 6, T.31N., R.1W.; in sandstone about $3 / 4$ mile up Hooten Gulch (a branch of South Cow Creek), from PG \& E Power house, about 300 yards downstream from north branch of Hooten Gulch

Str. position: Member V (upper part)

Fossils: Pseudoschloenbachia aff. P. boulei (BASSE) *, Baculites kirki Matsumoto*

Age: Upper Santonian or Lower Campanian

Coll.: M. V. KIRK, 9/18/1952

SOC. K-230A [ $\div$ CIT. 1250 , or close to that]

Area: Millville Quad. (Redding area), Shasta Co., NE. Sacramento Valley

Loc.: Sec. 5, T.31N., R.1W.; Hooten Gulch, branch of South Cow Creek, near its mouth, about $1 / 4$ mile up north branch from loc. 230 (which is about 50 feet upstream from mouth of north branch)

Str. position: Member V (upper part)

Fossil: Pseudoschloenbachia aff. boulei (BASSE) *

Age: Upper Santonian or Lower Campanian

Coll.: M. V. KIRK, $7 / 18 / 1952$

SOC. K-232 $[\div \mathrm{K}-44]$

Area: Millville Quad. (Redding area), Shasta Co., NE. Sacramento Valley

Loc.: Near boundary line of sec. 9 and 16, T.32N., R.3W.; east bank of Little Cow Creek, about 1/4 mile below WILLIAMs ranch and dam

Str. position: Member III (middle part)

Fossil: Subprionocyclus normalis (ANDERSON)

Age: Upper Turonian

Coll.: M. V. KIRK, 7/10/1952

SOC. K-234

Area: Yreka Quad., Siskiyou Co., N. California

Loc.: NW. $1 / 4$ of SW. $1 / 4$, sec. 33, T.47N., R.6W.; Klamath River, about 150 feet stratigraphically above the base of the Cretaceous in this area: on north projection of cliff at mouth of canyon just opposite foot bridge over river, about 50 feet from the top of cliff

Str. position: Member I of PECK et al.

Fossil: Subprionocyclus sp.

Age: Upper Turonian

Coll.: M. V. KIRK, 7/22/1952

SOC. K-235

Area: Yreka Quad., Siskiyou Co., N. California

Loc.: Near SW. corner sec. 28, T.47N., R.6W.; sandstone ridge just west of Hornbrook on north side of old highway 99 to east of ridge and north of Camp Lowe

Str. position: Probably Member V (upper) of PECK et al.

Fossils: Anapachydiscus deccanensis (SToLICzKA), Pachydiscus sp. (compressed, smoothish form, but weakly ornamented on the inner whorl), Metaplacenticeras pacificum (SMITH)

Age: Upper Campanian

Coll.: M. V. KIRK

SOC. K-237

Area: Rumsey Quad., Colusa Co., SW. Sacramento Valley

Loc.: NE. 1/4, sec. 7, T.13N., R.3W.; in small creek north of Sand Creek; collection 
in bed of creek from about the same horizon as loc. K-75 downstream

Str. position: Forbes formation (basal part)

Fossils: Patagiosites arbucklensis (ANDERSON), Baculites inornatus MEEK (small specimens)

Age: Campanian

Coll.: M. V. KIRK, 8/4/1952

SOC. K-238

Area: Rumsey Quad., Colusa Co., W. Sacramento Valley

Loc.: NE. 1/4, sec. 7, T.13N., R.3W.; south bank of Sand Creek, just below lone Oak tree on south side of road upstream from DobBins ranch about opposite loc. 73

Str. position: Forbes formation (basal part)

Fossil: Patagiosites arbucklensis (ANDERSON)

Age: Campanian

Coll.: M. V. KIRK, 8/4/1952

SOC. K-239

Area: Rumsey Quad., Yolo Co., W. Sacramento Valley

Loc.: NE. $1 / 4$ of SE. $1 / 1$ of sec. 22 , T.12N., R.3W.; in limestone concretions weathering out on hill just south of Lee Bow Well

Str. position: No record, presumably basal Forbes formation

Fossil: Cf. Patagiosites arbucklensis (ANDERson)

Agi:: Campanian (?)

Coll.: M. V. KIRK

SOC. K-240

Area: Rumsey Quad., Colusa Co., W. Sacramento Valley

Loc.: SW. $1 / 4$ of sec. 34, T.13N., R.3W.; from shale banks in Salt Creek below Blue Ridge Petrol. Well, just downstream from Springs and upstream from south heading tributary to Salt Creek

Str. position: Forbes formation (basal part)

Fossil: Patagiosites arbucklensis (ANDERson) (inner whorls)

Age: Campanian

Coll.: M. V. KIRK, $8 / 5 / 1952$

SOC. $\mathrm{K}-241$

Area: Capay Quad., Yolo Co., W. Sacramento Valley

Loc.: SW. $1 / 4$ of SW. $1 / 4$, sec. 2, T.8N., R.2W.; about $1 / 4$ mile west of Chapman's upper ranch on south bank of Enos Creek, in second of three recent gullies

Str. position: No formational name recorded

Fossils: Neophylloceras ramosum (MEEK), Desmophyllites diphylloides (FoRBes), Metaplacenticeras sp., Gaudryceras denmanense WhITEAVES

Age: Upper Campanian

Coll.: No record

SOC. K-244A

Area: Lodoga Quad., Colusa Co., W. Sacramento Valley

Loc.: Sec. 33, T.18N., R.4W.; south side of 3rd gully (next gully south of loc. 70), west slope of Logan Ridge in PETERSon ranch

Str. position: "Antelope shale"

Fossil: Beudanticeras [Brewericeras ?] cf. haydeni (GABB)

Age: Albian

Coll.: M. V. KIRK, 8/11/1952 
SoC. K-244B

Area: Lodoga Quad., Colusa Co., W. Sacramento Valley

Loc.: Sec. 33, T.18N., R.4W.; W. side Logan Ridge

Str. position: "Antelope shale", about 300 feet stratigraphically above loc. 244 A, about 35 feet below first sandstone

Fossils: Mortoniceras (Durnovarites) cf. quadratus (SPATH), Neophlycticeras (?) sp., Stomohamites sp.

Age: Upper Albian

Coll.: M. V. KIRK, 8/11/1952

UC. 2135

Area: Corona Quad. $(1: 125000)$, Orange Co., Santa Ana Mts., S. California

Loc.: $1 / 4$ mile N.15 ${ }^{\circ}$ E. of B.M. 1271; in small gully on right side of Santiago Canyon (see PACKARD, 1922, p. 415)

Str. position: No record, except an explanation by PACKARD (1916, p. 145)

Fossil: Baculites cf. inornatus MeEK

Age: Upper Campanian

Coll.: E. M. BUTTERWORTH (loc. 25)

UC. 2142

Area: Corona Quad. (1:125000), Orange Co., Santa Ana Mts., S. California

Loc.: 2.25 miles NNW. of B.M. 1271; left bank of Silverado Canyon in shale undercut by stream; about 200 feet $\mathrm{SE}$. of road

Str. position: "Lower portion of lower shale", that probably means lower part of Holz shale member

Fossils: Subprionocyclus cf. normalis (ANDERSON) (several specimens)

Age: Upper Turonian, probably near the top of Turonian

Coll.: E. L. PACKARd (loc. 637)

Remarks: See PACKARD, 1922, p. 415

UC. 2151

Area: Corona Quad. (1:125000), Orange Co., Santa Ana Mts., S. California

Loc.: $1 / 2$ mile N. of B.M. 1271 on ridge S.E. of canyon with a road, elevation 1600 feet. Specimens may have come from a piece of float

Str. position: "Middle Chico" (see PACKard, 1916, p. 145)

Fossil: Baculites cf. inornatus MEEK

Age: Upper Campanian

Coll.: E. L. PACKARD (loc. 632)

UC. 2166

Area: Corona Quad. (1:125000), Orange Co., Santa Ana Mts., S. California

Loc.: 3.75 miles S. $78^{\circ}$ E. from B.M. 610 ; first canyon N. of bee house on the right bank of Black Star Canyon; about 1000 feet from the road; elevation 1100 feet (see PACKARD, 1922, p. 416)

Str. position: "Middle Chico" (see PACKard, 1916, p. 145)

Fossil: Anapachydiscus californicus (YABE)*

Age: Probably Campanian

Coll.: E. L. PACKARD (loc. 630)

Remarks: This locality was referred by YABE and SHImizu, 1921, p. 58 (16)

UC. 2195

Area: Santiago Peak Quad., Orange Co., Santa Ana Mts., S. California

Loc.: "Float 200 yards N. of reservoir in Harding Canyon; under "a" in Harding 
Str. position: No record (calcareous sandstone)

Fossil: Subprionocyclus sp. juvenile [resembling immature of S. neptuni (GeINITZ)]

Age: Upper Turonian

Coll.: N. Cornwall (\# 328)

UC. 2208

Area: Sucia Island, San Juan Co., Washington

Loc.: Marine cliffs of the small island lying at the SW. corner of the group

Str. position: No record of formational name; probably somewhere in Nanaimo group Fossils: Canadoceras newberryanum (MEEK), Pachydiscus buckhami USHER

Age: Campanian

Coll.: E. L. PACKard (loc. 682)

UC. 2699

Area: Paradise Quad., Butte Co., E. Sacramento Valley

Loc.: No precise record, except "type Chico", Chico Creek

Str. position: Chico formation

Fossil: Canadoceras yokoyamai (JiMBo)

Age: Campanian

Coll.: No record

UC. 2701

Area: Paradise Quad., Butte Co., E. Sacramento Valley

Loc.: No precise record; "Butte Creek, loc. 2" in the Record Book and "Chico Creek" on the label

Str. position: No record, somewhere in the Chico formation

Fossil: Canadoceras yokoyamai (JIMBo) [=C. fraternum (GABB) in ANDERSON, 1958, pl. 50, fig. 1]

Age: Campanian

Coll.: No record

UC. A-169

Area: S.W. Oregon

Loc.: No precise record, but " 49 Mines, Oregon"

Str. position: No precise record

Fossil: Subprionocyclus sp. juvenile

Age: Upper Turonian

Coll.: No record

UC. A-170

Area: S. W. Oregon

Loc.: No precise record; "Tenn. Sмiтh ranch, 1.5 miles SW. of Phoenix"

Str. position: No record (matrix is silty, calcareous, and micaceous sandstone)

Fossil: Collignoniceras woollgari (MANTELL) *

Age: Turonian (middle to upper part suggested)

Coll.: No record

UC. A-173

Area: Shasta Valley, Siskiyou Co.

Loc.: No precise record; "RICHARDSON's ranch"

Str. position: No record

Fossil: Kossmaticeras aff. K. japonicum Matsumoto

Age: Lower Senonian suggested

Coll.: No record 
UC. A-407

Area: Baja California, Mexico

Loc.: 2 miles E. of Santa Catarina, at the beach

Str. position: No record, presumably Rosario formation

Fossil: Pachydiscus (Neodesmoceras) catarinae (ANDERSON and HANNA)

Age: Lower Maestrichtian (?) or close to the boundary of Campanian-Maestrichtian

Coll.: SANTILlan \& BARRERA

UC. A-963

Area: Chico Quad. (1:125000), Butte Co., E. Sacramento Valley

Loc.: No indication of sec., T. \& R.; Pentz ranch, on north bank of Dry Creek, $300-$ 400 yards west of bridge which is approximately 1.5 miles south of Pentz

Str.position: "Chico"

Fossil: Baculites chicoensis TrASK

Age: Campanian (rather lower part)

Coll.: C. W. Merriam \& F. E. Turner, 11/19/1931

UC. A-2957

Area: Pacheco Pass Quad., Merced Co., W. San Joaquin Valley

Loc.: Center of NE. 1/4, sec. 12, T.9S., R.7E.; Quinto Creek

Str. position: No record; according to T. MATSumoro's field observation the greenish grey shale of this kind at the recorded locality is situated below the fourth conglomerate (from bottom) of the Quinto Creek section

Fossils: Collignoniceras sp. juvenile, cf. woollgari (MANTELL)

Age: Turonian (probably middle part)

Coll.: Allan BenNison, 1937 (summer) (\# 278)

UC. A-3005

Area: Pacheco Pass Quad., Merced Co., W. San Joaquin Valley

Loc.: SW. corner SE. 1/4, sec. 1, T.9S., R.7E.; Quinto Creek

Str. position: No record; in greenish grey sandstone, presumably somewhat above the bed represented by UC. A-2957

Fossil: Subprionocyclus sp.

Age: Upper Turonian

Coll.: Allan Bennison, Oct., 1937 (\#292)

UC. A-3057

Area: Volta Quad. (7.5 minute), Merced Co., W. San Joaquin Valley

Loc.: NE. $1 / 4$, SE. $1 / 4$, sec. 26 , T.10S., R.9E.

Str. position: Garzas sandstone of BENNISON

Fossil: Baculites columna MoRToN

Age: Maestrichtian

Coll.: A. BenNison (\#309)

UC. $A-3100$

Area: Baja California, Mexico

Loc.: Santa Catarina Landing; about 4 miles up canyon from landing, and about 100 feet above bottom of canyon

Str. position: Rosario formation

Fossil: Pachydiscus (Neodesmoceras) princeps (ANDERSON), holotype

Age: Lower Maestrichtian or Upper Campanian

Coll.: Arthur BRIDGe, summer of 1938

UC. A-3158

Area: Pacheco Pass Quad., Stanislaus Co., W. San Joaquin Valley 
Loc.: Near center of N. 1/2, sec. 19, T.8S., R.8E.; in shale outcrop on gully, south of Garzas Creek

Str. position: "Moreno" according to A. BENNison; upper part of Panoche group according to M. B. PAYNE's map (1951, pl. 1)

Fossils: Natural cast of the specimen in CAS. (holotype of "Turrilites excelsus ANDERSON"=Nostoceras splendidum (SHUMARD)

Age: Uppermost Campanian or Lowest Maestrichtian

Coll.: Allan BenNison

UC. A-3378

Area: Carbona Quad., San Joaquin Co., W. San Joaquin Valley

Loc.: 0.16 mile E. and 0.25 mile S. of NW. corner of sec. 34, T.4S., R.5E.; Hospital Creek

Str. position: "Horsetown"

Fossils: Leconteites cf. lecontei (ANDERSON) [mislabelled as Oregoniceras sp.], Syncyclonema sp.

Age: Albian

Coll.: Allan Bennison, summer 1940 (\# 484)

UC. A-3404

Area: Corona Quad. (1:125000), Orange Co., Santa Ana Mts., S. California

Loc.: Near San Juan Capistrano; in boulder of float in Lucas Canyon, a branch of San Juan Canyon

Str. position: No record

Fossil: Baculites cf. inornatus MEEK

Age: Campanian

Coll:: Nomland, Gestek, \& Carlson, Sept. 1916

UC. A-3823

Area: Carquinez Quad., Contra Costa Co., Bay area

Loc.: "1 mile southeast of town of Crockett, in water tunnel, 120 feet from portal, probably 60 feet below surface, elevation 250 feet

Str. position: No formational name, but with "Horsetown" in the record book; imbedded in yellow clay

Fossil: Mantelliceras (?) lecontei (ANDERSON), holotype

Age: Lower Cenomanian is suggested

Coll.: W. F. Boardmann, 1899

UC. A-3826

Area: Ortigalita Peak Quad., Fresno Co., W. San Joaquin Valley

Loc.: Near SW. corner, sec. 5, T.13S., R.11E.; N. side of ravine 1.2 miles upstream from junction with south fork of Wildeat Canyon, which is 2.5 miles N. of Little Panoche Creek

Str. position: Limestone concretion about 200 feet below the uppermost concretionary sand in the Cretaceous of the area [upper part of Panoche group in M. B. PAYNE's map $(1951, \mathrm{pl} .1)]$

Fossil: Glyptoxoceras indicum (FORBES)* (several well preserved specimens)

Age: Upper Campanian or Lower Maestrichtian

Coll.: A. Bennison (\#202)

UC. A-3827

Area: Ortigalita Peak Quad., Fresno Co., W. San Joaquin Valley

Loc.: Near boundary line of sec. 7 and 8, T.13S., R.11E.; shale exposure in sharp bend of stream $1 / 2$ mile NW. of buildings in center of W. $1 / 2$, sec. 8 
Str. position: No record of formational name; 500 feet stratigraphically below massive brown concretionary sandstone [upper part of Panoche group in M. B. PAYNE's map (1951, pl. 1)]

Fossil: Anapachydiscus (?) sp. [a large outer whorl, comparable to A. californicum. ( $\mathrm{YABE})]$

Age: Campanian (probably upper part)

Coll.: A. BENNISON (\#203)

UC. A-4470

Area: Rumsey Quad., Colusa Co., W. Sacramento Valley

Loc.: E. portion of NE. $1 / 4$ of sec. 7, T.13N., R.3W.; outcrop on both sides of narrow NE-SW trending ridge, immediately W. of B.M. 584 near W. edge of sec. 8, on DoBbins ranch

Str. position: Limestone concretions in Upper Cretaceous shale, cropping out as a window in the Pliocene. The shale is referred by KIRBY to the basal part of Forbes formation

Fossils: Patagiosites arbucklensis (ANDERSON) (in limy concretions); Baculites inornatus MEEK (in calcareous silty sandstone, which has the same UC. A-4470 number)

Age: Campanian

Coll.: Theo Crook (Geol. Dept.)

UC. A-4530

Area: Sucia Island, San Juan Co., Washington

Loc.: Strait of Juan de Fuca to Georgia Strait

Str. position: The top 100 feet of the section; from A-4528 to the north corner of the tip of the southern margin of Fossil Bay

Fossil: Canadoceras cf. newberryanum (MEEK)

Age: Campanian

Coll.: J. W. Durham, 7/28/1948 (434)

UC. A-4655

Area: Paradise Quad., Butte Co., E. Sacramento Valley

Loc.: No record of sec., T. \& R.; along north bank of Chico Creek about 2.5 miles down dirt road which cuts off to north from highway 32 (out of Chico) at "Tenmile house". This is the first easily accessible place along the stream coming upstream.

Str. position: Chico formation (s.s.)

Fossil: Baculites chicoensis Trask

Age: Campanian (probably lower part)

Coll.: Paleo. 103 Class

UC. A-4684

Area: Volta Quad. (7.5 ser.), Merced Co., W. San Joaquin Valley

Loc.: Middle of E. side of SW. $1 / 4$ of sec. 26 , T.10S., R.9E.; in a poor outcrop near the top of a hill in a hard sandstone weathering to a friable sandstone

Str. position: Garzas sandstone; base of the member by Allan BENNISON

Fossils: Baculites columna Morton*, Baculites (?) aff. B. teres (ForBes) *, pelecypods $\&$ gastropods

Age: Maestrichtian

Coll.: Paleo. 103 Class, 1948; entered by M. V. KIRK, 2/17/1949

UC. A-4852

Area: Lodoga Quad., Glenn Co., W. Sacramento Valley 
Loc.: Center of W. half of sec. 8, T.18N., R.4W.; on north slope of Hill 629, about half way between hilltop and Hunters Creek

Str. position: No record; within the so-called Antelope shale

Fossil: Calycoceras boulei Collignon*

Age: Cenomanian (middle to upper part)

Coll.: I. Valov, 1948

UC. A-4864

Area: Fruto Quad., Glenn Co., W. Sacramento Valley

Loc.: South of center of sec. 32 , T.20N., R.5W.; in stream cut of Clark Valley

Str. position: No record; a shale unit below the equivalent of Venado sandstone, according to CHUBER's interpretation

Fossil: Calycoceras ef. orientale Matsumoto, SAito, \& Fukada*

Age: Cenomanian (middle part)

Coll:: I. Valov, 1948

UC. A-4866

Area: Fruto Quad., Glenn Co., W. Sacramento Valley

Loc.: NE. $1 / 4$ of NE. $1 / 4$, sec. 17 , T.20N., R.5W.; on top of a small hill, about $3 / 4$ mile northeast of Fruto

Str. position: Venado sandstone equivalent (?)

Fossil: Tetragonites glabrus (JIMBO)

Age: Turonian (?)

Coll.: I. Valov (?)

UC. A-4890

Area: Reef Ridge Quad. (7.5 ser.), Kings Co., SW. San Joaquin Valley

Loc.: SW. $1 / 4$ of SE. $1 / 4$ of sec. 27, T.23S., R. 16E.; on small creek coming into Avenal Creek from the SW.

Str. position: "About 100 feet stratigraphically below the base of the McLure, Panoche formation"

Fossil: Baculites rex ANDERSon

Age: Maestrichtian (probably lower part at this loc.)

Coll.: Bud OGLE, Geol. 102B Class, April 1949; entered by M. V. KIRK, 6/29/1949

UC. A-4959

Area: Simmler Quad., Kern Co., SW. San Joaquin Valley

Loc.: No indication of sec., T. \& R.; Media Agua Creek

Str. position: "Ammonites and mollusks collected from float concretions in the bed Media Agua Creek beginning at Grid line 139000 southward to large canyon northwest of Ross ranch"

Fossil: Baculites rex ANDERSON*

Age: Maestrichtian

Coll.: Paleo. 137 Class, 9/25/1949

UC. A-4976

Area: Mt. Boardman Quad., Stanislaus Co., W. San Joaquin Valley

Loc.: 1200 feet SE. along Orestimba Creek from BM. 659, S.W. of Wilcox Ridge between Grid Coordinates 1610 and 1615 and 970 and 175 on south side of Creek Str. position: No precise record, except "Panoche formation"

Fossils: Hyphantoceras sp. and other mollusks

Age: Somewhere in Turonian-Santonian

Coll.: W. Yerington for Robert N. HACKer, Sept. 1949 
UC. A-4986

Area: Point Arena Quad., Mendocino Co.

Loc.: In talus slopes at the south end of Anchor Bay beach; about 25 feet S. of the end of the sandy beach

Str. position: Gualala formation; limy shale and fine sandstone

Fossil: Didymoceras cf. hornbyense (Whiteaves)

Age: Upper Campanian

Coll.: M. V. KIRK, 6/12/1949

UC. A-4987

Area: Lodoga Quad., Colusa Co., W. Sacramento Valley

Loc.: "PETERSON ranch", about 4.5 miles north of Sites, about two thirds of the way up the west side of Logan Ridge, in the first gully south of the pass

Str. position: Limy concretion from the shale about 25 feet below the base of Venado sandstone formation

Fossil: Pseudohelicoceras petersoni (ANDERSON)

Age: Upper Albian

Coll.: M. V. KIRK, summer 1949

UC. A-5179

Area: Rumsey Quad., Yolo Co., SW. Sacramento Valley

Loc.: No record of sec., T. \& R.; west side Capay valley in position about west of Guinda

Str. position: "Limestone concretion in shale just below Capay Eocene and just above first Cretaceous sandstone"

Fossil: Baculites schencki Matsumoto* (a variety close to B. yokoyamai Tokunaga \& Shimizu)

Age: Coniacian (?)

Coll.: Theo Crook, Dept. Geol. UC.; entered by H. T. HorLyn, 3/10/1950

UC. A-6293

Area: Point Arena Quad., Mendocino Co., W. Coast

Loc.: N. end of Anchor Bay; found in talus slope about 100 feet E. of first beach area, E. of conglomerate (A-4985) making N. point of bay

Str. position: Gualala formation

Fossil: Diplomoceras (?) sp.

Age: Upper Campanian or Maestrichtian

Coll.: M. V. KIRK, 5/3/1950

UC. A-6458

Area: Siskiyou Mountain

Loc.: No record

Str. position: No record

Fossil: Sciponoceras baculoide (MANTELL)

Age: Cenomanian

Coll.: No record

UC. A-6588

Area: Oroville Quad., Butte Co., E. Sacramento Valley

Loc.: "Pences ranch" (no further record)

Str. position: Chico formation (s.s.)

Fossils: Canadoceras cf. newberryanum MEEK, Baculites chicoensis TraSK

Age: Campanian

Coll.: No record 
UC. A-6589

Area: Sacramento Quad., Placer Co., E. Sacramento Valley

Loc.: No record of sec., T. \& R.; "TRACH ranch, Rock Corral, Placer Co."

Str. position: No record

Fossil: Baculites cf. occidentalis MEEK

Age: Upper Campanian

Coll.: “G.B."; entered by E. C. Allison, 10/12/1950

UC. A-6598

Area: Covelo Quad., Mendocino Co., W. Coast

Loc.: Near SW. corner of NE. $1 / 4$ of NW. 1/1 of sec. 36, T.22N., R.13W.; Covelo-Dos Rios road, W. of Kelly Creek

Str. position: See Univ. Calif. Publ. Bull. Dept. Geol. Sci., vol. 25, No. 2

Fossil: Pseudophyllites cf. indra (ForBes) (close to the examples of Nanaimo group) (misidentified as Pachydiscus)

Age: Lower Maestrichtian (?) or Upper Campanian

Coll.: S. G. CLARK

UC. A-6606

Area: Ortigalita Peak Quad., Fresno-Merced Co., W. San Joaquin Valley

Loc.: SW. 1/4, NE. 1/4, sec. 12, T.11S., R.10E.; Glycymeris reef at Los Banos Creek, first bold outcrop near mouth of Los Banos Creek

Str. position: "Glycymeris reef in Panoche group"

Fossil: Very poorly preserved specimen Anapachydiscus (?) sp.

Age: Uncertain

Coll.: L. I. BRIGGS, 1948-49

UC. A-6621

Area: Ortigalita Peak Quad., Merced Co., W. San Joaquin Valley

Loc.: NW. 1/4, NE. 1/4, sec. 32, T.12S., R.10E.; east of Ortigalita Creek

Str. position: 16000 feet stratigraphically below the top of the Panoche group

Fossil: Baculites cf. yokoyamai TokUNAGA and SHImizu* [Read Baculites cf. $B$. yokoyamai for Baculites aff. B. yokoyamai in the explanation of Text-fig. 26 (p. 118) of Part I]

Age: Probably Coniacian

Coll.: L. I. BRIGGS

Remarks: This species was indicated as Baculites chicoensis ? by BrIGGS (1953, p. 32).

UC. A-7223

Area: Mt. Vaca (7.5 minute) Quad., Solano Co., W. Sacramento Valley

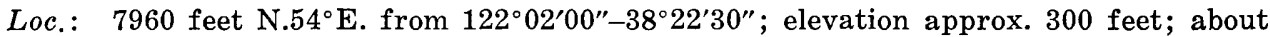
halfway up on exposed cliff on E. side of Ulatus Creek; $\mathrm{S} .33^{\circ} \mathrm{W}$. from powerline tower on E. edge of Vaca Valley floor

Str. position: No formational name; gray-blue shale

Fossils: Baculites cf. rex ANDERSon, small mollusks and foraminifera

Age: Maestrichtian or Upper Campanian

Coll.: Geol. 118, Summer 1951

UC. A-7234

Area: Capay Quad., Yolo Co., W. Sacramento Valley

Loc.: 4888 feet S. $47.4^{\circ} \mathrm{W}$. from B.M. 312 which is located by road about $1 / 4$ mile E. of ScotT ranch buildings. Elevation about 385 feet; 1267 feet E. and 898 feet S. of S.W. corner of sec. 35, T.9N., R.2W.

Str. position: No formational name; limestone which strikes across road about 200 
feet N. of "Gate No. 1" on ScotT ranch. It also outcrops on hillside S. of Pine Creek, where most of the ammonites were found; far above the Guinda sandstone.

Fossils: Phyllopachyceras forbesianum (D'ORBIGNy), Desmophyllites sp., Anapachydiscus [or Menuites] sp. juv., Baculites rex ANDERson, Baculites (?) aff. teres FORBES

Age: Lower Maestrichtian suggested

Coll.: Geol. 118, Summer 1951; Paleo. 117, Feb. 1958

UC. A-7237

Area: Mt. Vaca (7.5) Quad., Solano Co., W. Sacramento Valley

Loc.: 3792 feet N.43.4 ${ }^{\circ}$ W. of B.M. 328 which is located by Pleasants Valley Road slightly more than one mile N. of Gates Canyon turnoff; elevation approx. 550 feet; N.88.5 ${ }^{\circ}$ W. of Dunn Peak, on W. side of Vaca Valley

Str. position: No formational name; limestone below white platy shale at the top of Cretaceous section

Fossils: Cf. Metaplacenticeras pacificum (Sмітн)

Age: Upper Campanian

Coll.: Geol. 118, Summer 1951

UC. A-7305

Area: Morgan Valley Quad., Yolo Co., W. Sacramento Valley

Loc.: N. W. corner of S. W. $1 / 4$ of sec. 3, T.12N., R.4W.; just N. of first "E" in Cache Creek at elevation of approximately 570 feet

Str. position: Siltstone interbedded in massive "Vanada" [Venado] sandstone approximately 8 feet stratigraphically below conglomerate at locality A-7304. Material might possibly be reworked but this seems doubtful

Fossil: Tetragonites sp.

Age: Uncertain

Coll.: Geol. 118, Summer 1951

UC. A-7581

Area: Reef Ridge Quad., Kings Co., W. San Joaquin Valley

Loc.: Center of W. 1/2 of sec. 27, T.23S., R.16E.; on south-facing slope which terminates in small closed contour 1700 feet

Str. position: Limy concretions weathered from clay shale, 200 feet interval below contact with McClure shale

Fossils: Baculites cf. inornatus MEEK (many specimens are secondarily compressed), Neophylloceras ramosum (MEEK), Inoceramus sp.

Age: Campanian

Coll.: Paleo. 137, 1951

UC. A-9544

Area: Baja California, Mexico

Loc.: North of San Isidro; up the Arroyo Jvé (immediate north of Punta San Isidro) from bluff along east bank of stream about 200 yards upstream from old adobe hut

Str. position: No formational name recorded; tuffaceous sands with occasional fossiliferous layers

Fossil: Pachydiscus (Neodesmoceras) (?) sp. (large, weathered specimen)

Age: Lower Maestrichtian suggested

Coll.: Durham, Peck, \& Emerson, 6/21/1953

UC. A-9753

Area: Ortigalita Peak Quad., Fresno Co., W. San Joaquin Valley

Loc.: About 125 yards west from the north-south section line between sec. 7 and 8 
in NE. 1/4 of sec. 7, T. 13S., R.11E.; north bank of Wildcat Canyon

Str. position: "Pachydiscus silt"; the cut bank consists of about 60 feet of silty sands with occasional thin sandy beds. This locality falls in the relatively upper part, but not highest part, of Panoche group in M. B. PAYNE's map (1951, pl. 1).

Fossil: Anapachydiscus (?) cf. californicus (YABE)

Age: Upper Senonian (probably Upper Campanian)

Coll.: Paleo. 137, Oct. 1953.

UC. A-9754

Area: Ortigalita Peak Quad., Fresno Co, W. San Joaquin Valley

Loc.: Slightly E. of center of sec. 6, T.13S., R.11E.; north branch of Wildcat Canyon, about $2 / 3$ mile northwest of loc. A-9753. Shale and silt exposed on north bank at about the west edge of the "C" in County (of Fresno Co.). This is just east of the county line and in the same grey brown silty sands as loc. A-9753.

Str. position: "Pachydiscus silt"

Fossil: Anapachydiscus cf. californicus (Y $\mathrm{ABE}$ ) (foram. collected)

Age: Upper Senonian (probably Upper Campanian)

Coll.: Paleo. Class 137, Oct. 1953

UC. B-769

Area: Mt. Boardman Quad., Stanislaus Co., W. San Joaquin Valley

Loc.: Survey Coordinates or Grid 964490-1626500; road cut

Str. position: No formational name; shale in road cut "probably about same age as B-776. This unit of shale with interbedded sandstone occurs between the rocks of "Franciscan complex", with supposed fault contact

Fossil: Collignoniceras (?) sp. (very poorly preserved)

Age: Turonian is suggested, but not clear

Coll.: Marshall MADDock, 1952-54 (31-70-1F)

UC. B-776

Area: Mt. Boardman Quad., Stanislaus Co, W. San Joaquin Valley

Loc.: No precise record; "on crest of spur"

Str. position: "Broken fossils contained in gritty conglomerate, believed to have been deposited with conglomerate

Fossil: Peroniceras (?) sp.

Age: Coniacian is suggested, but not clear

Coll.: Marshall MadDock (31-51-4F), 1952-54

UC. B-2040

Area: . Capay Quad., Nappa-Solano Co., W. Sacramento Valley

Loc.: Near center of N. $1 / 2$, sec. 29 , T.8N., R.2W.; excavation of Monticello dam on Putah Creek, close to county boundary of Nappa-Solano-Yolo

Str. position: Greenish conglomerate in the lower part of the sandstone unit, forming the ridge of Vaca Mountains. This was referred to the Venado sandstone by KIRBY (1943).

Fossil: Romaniceras n. sp. (?) aff. R. inerme (DE GRossouvre)

Age: Turonian

Coll.s A. C. Hestmark

UC. B-2361

Area: Carbona Quad., San Joaquin Co., W. San Joaquin Valley

Loc.: N. 1642550, E.9624; Hospital Creek, slightly on north side of ridge

Str. position: From the bed below the conglomerate mapped as base of Upper Cretaceous on the 1250 feet contour (3116 NW. as measured on map). Fossils are in a argillaceous ss. member in silty sandstone 
Fossil: Beudanticeras huleni ANDERson

Age: Albian

Coll.: Gilbert \& Geol. Class, Apr. 1955

UC. B-2881

Area: Santa Clara Desert, Baja California "F-8081-1"

Loc.: No precise record; "Field note book has been lost and the locality is not mentioned in the pertinent report, according to memorandum of L. L. TABOR (Feb. 4, 1957), but it is reasonably certain that the ammonites were collected from the Upper Cretaceous terrain that borders Bahia Tourtugas (Cabo Tortolo)."

Str. position: "1725.3"

Fossil: Sharpeiceras sp. (transitional to Graysonites) [Sharpeiceras cf. indicum (Kossmat) according to Wright's letter to E. C. Allison, April 1, 1957]

Age: Lower Cenomanian

Coll.: R. P. Miller \& L. L. TABor, Richmond Pet. Co., May 1950

UC. B-4149

Area: Ortigalita Quad., Merced Co., W. San Joaquin Valley

Loc. NW. 1/4, SE. 1/4, sec. 33, T.11S., R.10E.; approximately 1.5 miles south of the mouth of Ortigalita Creek near Los Banos, on both north and south sides of the creek

Str. position: 5-15 feet thick, light brown, medium-grained ss. containing small lenses of chert pebbles and crab-bearing limy concretions 1 to 3 inches in diameter

Fossils: Pachydiscus cf. egertoni (ForBes)*, Anagaudryceras mikobokense CoLLIGNON*, Gaudryceras (Vertebrites) cf. kayei (FoRBEs), Glyptoxoceras subcompressum (Forbes) (abundant)

Age: Lower Maestrichtian or uppermost Campanian

Coll.: Paleo. 3 and Monterey Peninsula College Apr. 1957; Paleo. 137, Oct. 1957

UC. B-4163

Area: Panoche Quad. (1:125000), San Benito Co., W. San Joaquin Valley

Loc.: In the SW. $1 / 4$ of the township bounded by T. 15S., R.12E.; at Silver Creek, about $1 / 2$ mile $W$. of Panoche highway bridge over Silver; on north side of road about $1 / 4$ mile from road

Str. position: Tierra Loma shale of Moreno formation

Fossils: Eubaculites sp., cf. E. ootacodensis (Stoliczka), Diplomoceras (?) sp.

Age: Maestrichtian

Coll.: S. P. Welles, Aug. 1956

UC. No number

Area: SW. Oregon

Loc.: No precise record; "SмIтH ranch, 3 miles W. of Phoenix"

Str. position: No record

Fossil: Inoceramus incertus (JIMBo) (close to I. latus SowERBY) [=I. jacksonensis ANDERSoN, 1958, holotype]

Age: Turonian

Coll.: No record

UC. No number

Area: SW. Oregon

Loc.: No precise record; "FITCH ranch, 3 miles west of Phoenix, Oregon"

Str. position: No precise record

Fossil: Subprionocyclus branneri (ANDERSON)* (UC. 12105)

Age: Turonian

Coll.: E. PACKARD (?) (\#169-170) 
UCLA. 2415

Area: El Toro Quad., Orange Co., Santa Ana Mts.

Loc.: No record of sec., T. \& R.; sandstone on spur about 1 mile NE. of LAMBERT ranch, above creek in Bee Canyon

Str. position: Uncertain. This locality is an elevated fault block bounded on all sides by Miocene

Fossils: Anapachydiscus aff. A. arrialoorensis (SToLICZKA), Metaplacenticeras cf. pacificum (SMITH), Pseudophyllites sp., Baculites cf. rex. ANDERson, Eutrephoceras sp.

Age: Highest Campanian or lowest Maestrichtian (According to PoPENoE, the fauna suggests a horizon about equivalent to the Pleasants sandstone, but possibly a little younger.)

Coll.: L. E. Saul, June 1949

UCLA. 3368

Area: Millville Quad. (Redding area), Shasta Co., NE. Sacramento Valley

Loc.: Slightly south of N. line of sec. 12, T.31N., R.3W.; left bank of Clover Creek, about $1 / 4$ mile downstream from a small dam across the creek; 2.7 miles N.51 ${ }^{\circ} \mathrm{E}$. of B.M. 510 at intersection of Wiltmore road and State highway 44, in Millville

Str. position: Member IV

Fossils: Damesites damesi intermedius Matsumoto, Eupachydiscus aff. E. teshioensis (JiмBo) *

Age: Lower Senonian (Coniacian or Santonian)

Coll.: James Valentine, 1954

UCLA. 3369

Area: Millville Quad. (Redding area), Shasta Co., NE. Sacramento Valley

Loc.: NW. $1 / 4$ of SE. $1 / 4$ of sec. 6, T.31N., R.1W.; left bank of Hooten Gulch, about $1 / 8$ mile upstream from the power house, and $1 / 2$ mile upstream from the juncture of Hooten Gulch with South Cow Creek

Str. position: Member V (near top)

Fossils: Texasia (?) sp., Pseudoschloenbachia sp., Baculites sp. indet.

Age: Satonian (?)

Coll.: Victor Church \& W. P. Popenoe, July 1936

UCLA. 3370

Area: Palocedro Quad. (1:125000) (Redding area), Shasta Co., NE. Sacramento Valley

Loc.: Sandstones cropping out along Hooten Gulch about 2.6 miles upstream from the juncture of Hooten Gulch and South Cow Creek, and about 9.0 miles N.80 E. of center of Millville

Str. position: Upper part of Member V (close to the contact between V \& VI)

Fossil: Bostrychoceras aff. B. otsukai ( $\mathrm{YABE}) *$

Age: Santonian

Coll.: John FrICK, 1952

UCLA. 3371

Area: Millville Quad. (Redding area), Shasta Co., NE. Sacramento Valley

Loc.: About 1/4 mile N. of SE. corner of sec. 6, T.32N., R.3W.; 1.1 miles nearly due north of Bella Vista on left bank of Dry Creek

Str. position: Member II, about 50 feet stratigraphically above the base of Member II

Fossil: Tetragonites cf. glabrus (JIMBo)

Age: The species is long ranged through Turonian-Santonian in Japan, but in California occurs in Turonian

Coll.: R. W. Imlay \& W. P. Popenoe, 8/13/1955 
UCLA. 3372

Area: Millville Quad. (Redding area), Shasta Co., NE. Sacramento Valley

Loc.: 2500 feet W. of NE. corner, sec. 20, T.32N., R.2W.; 1750 feet N.35 ${ }^{\circ}$. of the HuNT ranch house, Oak Run Valley

Str. position: Member IV

Fossils: Hauericeras sp. indet., Baculites sp. cf. B. schencki Matsumoto or B. boulei CollignoN

Age: Lower Senonian

Coll.: R. W. Imlay \& W. P. Popenoe, 8/14/1955

UCLA. 3373

Area: Millville Quad. (Redding area), Shasta Co., NE. Sacramento Valley

Loc.: 2750 feet $\mathrm{N} .58^{\circ} \mathrm{W}$. of SE. corner, sec. 17, T.32N., R.2W.; N. side of Oak Run Valley

Str. position: Member IV

Fossil: Texanites cf. kawasakii (KAWADA)*

Age: Lower Senonian (Upper Coniacian or Lower Santonian)

Coll.: R. W. Imlay \& W. P. Popenoe, 4/14/1955

UCLA. 3374

Area: Millville Quad. (Redding area), Shasta Co., NE. Sacramento Valley

Loc.: 4750 feet S.75 ${ }^{\circ}$ W. of NE. corner of sec. 20, T.32N., R.2W.; Oak Run Valley

Str. position: Member IV (weathered limonitic brown, calcareous nodule in mudstone)

Fossils: Baculites capensis WooDs, Inoceramus sp. (prism)

Age: Lower Senonian

Coll.: No record

UCLA. 3617

Area: Paradise Quad., Butte Co., E. Sacramento Valley

Loc.: Sec. 1, T.23N., R.2E.; approximately $1 / 2$ mile upstream from MICKEY's house on W. side of Chico Creek

Str. position: Chico formation (s.s.) (lower part, approximately 50 feet below the highest prominent conglomerate)

Fossil: Baculites schencki Matsumoto*

Age: Lower Senonian

Coll.: R. B. SAUL, 8/14/1955

UCLA. 3619

Area: Paradise Quad., Butte Co., E. Sacramento Valley

Loc.: Sec. 12, T.23N., R.2E.; Chico Creek, first ravine to south of bridge below MICKEY's house on $\mathrm{E}$. side of Chico Creek and approximately 1/6 mile upstream from Chico Creek county road

Str. position: Chico formation (s.s.)

Fossil: Baculites sp. juvenile (cf. B. yokoyamai Tokunaga \& ShImIzU; could be young smooth shell of $B$. boulei or B. capensis)

Age: Lower Senonian

Coll.: L. E. \& R. B. SAUL, 8/11/1952

UCLA. 3623

Area: Paradise Quad., Butte Co., E. Sacramento Valley

Loc.: Sec. 12, T.23N., R.2E.; Chico Creek, on east bank of Chico Creek west of triangular meadow nearly opposite mouth of deep ravine and about 1.25 miles $\mathrm{S}$. of MickeY's house

Str. position: Chico formation (s.s.) (relatively lower part) 
Fossils: Mesopuzosia cf. densicostata Matsumoto, Hauericeras sp. fragment, Baculites sp. indet. (possibly B. yokoyamai Tokunaga \& SHIMIZU), Bostrychoceras aff. $B$. otsukai (Y $\mathbf{A B E})$

Age: Santonian (?)

Coll.: L. E. \& R. B. SAUL, 8/16/1952

UCLA. 3627

Area: Paradise Quad., Butte Co., E. Sacramento Valley

Loc.: Approx. 30 feet S. of sec. 12, in sec. 13, T.23N., R.2E.; east bank of Chico Creek: Outcrop forms west edge of square meadow with fenced oak trees and spring: (SS-15-52)

Str. position: Chico formation (s.s.) (lower-middle part)

Fossils: Hauericeras sp., Bostrychoceras aff. otsukai (YABE), Baculites capensis Woods* (abundant)

Age: Santonian

Coll.: $\quad$ L. E. \& R. B. SAUL, 8/17/1952

UCLA. 3633

Area: Paradise Quad., Butte Co., E. Sacramento Valley

Loc.: Sec. 13, T.23N., R.2E.; east side of an untended road which leaves Humboldt road approx. $1 / 3$ mile south of "14-mile house" site and joins Chico Creek county road just north of northern $\mathrm{HB}$ gate; Loc. is on a ridge approx. $1 / 8$ mile up from county road, elev. 960 feet: (SS-1-52)

Str. position: Chico formation (s.s.) (relatively lower part)

Fossils: Hauericeras (Gardeniceras) angustum YABE, Gaudryceras cf. denmanense Whiteaves, Polyptychoceras (?) sp. cf. P. obstrictum (Jiмво), Baculites cf. capensis WooDs

Age: Santonian

Coll.: $\quad$ L. E. \& R. B. SAuL, $8 / 10 / 1952$

UCLA. 3636

Area: Paradise Quad., Butte Co., E. Sacramento Valley

Loc.: About 350 feet E. and 2000 feet S. of NW. corner, sec. 13, T.23N., R.2E.; east bank of Chico Creek, west from $\mathrm{HB}$ house and approximately 425 feet $\mathrm{S}$. of twin meadows

Str. position: Chico formation (s.s.)

Fossils: Canadoceras mysticum Mатsumoto*, Baculites sp.

Age: Campanian

Coll.: L. E. \& R. B. SAUL

UCLA. 3637

Area: Paradise Quad., Butte Co., E. Sacramento Valley

Loc.: Just barely inside E. line of sec. 14, T.23N.; east bank of Chico Creek, approx. $1 / 2$ mile $\mathrm{S}$. of southern $\mathrm{HB}$ gate and west of sharp bends in Chico Creek county road: (SS-17-52)

Str. position: Chico formation

Fossils: Canadoceras yokoyamai (Јімво) *, Canadoceras mysticum MATSuмото*, Submortoniceras chicoense (TRASK), Ryugasella ryugasensis WRIGHT \& MATSUMOTO, Pseudoxybeloceras lineatum (GABB)*, Baculites chicoensis TrAsK

Age: Campanian

Coll.: L. E. \& R. B. SAUL, 8/18/1952

UCLA. 3642

Area: Paradise Quad., Butte Co., E. Sacramento Valley 
Loc.: Sec. 26, T.23N., R.2E.; west bank of Chico Creek, approximately N.27 ${ }^{\circ} \mathrm{W}$. of BM. 1770; west of big westward projection of east lava cap: (SS-21-52)

Str. position: Chico formation (s.s.) (upper part)

Fossils: Neophylloceras cf. ramosum (MEEK), Pachydiscus sp. juvenile (cf. P. neevesi Whiteaves), Canadoceras sp., Submortoniceras chicoense (TRASK), Gaudryceras sp. juvenile (cf. G. denmanense WHITEAVES), Glyptoxoceras (?) sp., Baculites chicoensis TRASK

Age: Campanian

Coll.: L. E. \& R. B. SAUL

UCLA. 3647

Area: Paradise Quad., Butte Co., E. Sacramento Valley

Loc.: Sec. 35, T.23N., R.2E.; east side of Chico Creek up ravine which is 1.7 miles from "10-mile house" by Chico Creek county road; leached fossils in sandstone approx. 150 feet up-stream from county road and near a large block of basalt

Str. position: Chico formation

Fossils: Submortoniceras chicoense (TRASK), Pachydiscus buckhami USHER, Glyptoxoceras (?) sp., Baculites chicoensis Trask (abundant)

Age: Campanian

Coll.: L. E \& R. B. SAUL, 9/1/1953

UCLA. 3648

Area: Paradise Quad., Butte Co., E. Sacramento Valley

Loc.: Sec. 35, T.23N., R.2E.; "Fossil Bluff": sandstone bluff exposed on west side of Chico Creek, about $1 / 4$ mile above Salt Springs and approximately 200 feet above stream bed

Str. position: Chico formation (s.s.) (This is the stratigraphically highest ammonite locality in the Chico Creek.)

Fossils: Canadoceras (?) sp., Zelandites sp.* (resembling Z. kaiparaensis MARSHALL), Glyptoxoceras (?) sp., Baculites chicoensis TraSK

Age: Campanian

Coll.: L. E. \& R. B. SAUL, 8/21/1952

UCLA. 3781

Area: Santiago Peak Quad., Orange Co., Santa Ana Mts., S. California

Loc.: 800 feet E. and 1600 feet S. of NW. corner, sec. 16, T.5S., R. 7W.; along forest service road near crest of ridge between Silverado and Williams Canyons: (P2-34)

Str. position: Baker Canyon member; "lowest sandstone" in the faulted block

Fossil: Subprionocyclus sp. indet [cf. S. normalis (ANDERSON)]

Age: Upper Turonian

UCLA. 3782

Area: Millville Quad. (Redding area), Shasta Co., NE. Sacramento Valley

Loc.: E. of middle of $1 / 2$ E., sec. 17, T.32N., R.2W.; about $3 / 4$ mile NW. of Hathaway

Bros ranch house, N. side of Oak Run Valley: (P27-36)

Str. position: Member IV (dark gray shale)

Fossil: Eupachydiscus aff. E. teshioensis (Jімво)

Age: Senonian

Coll.: W. P. Popenoe, 6/30/1936

UCLA. 3783

Area: Millville Quad. (Redding area), Shasta Co., NE. Sacramento Valley

Loc.: Near the middle of E. line of NW. $1 / 4$, sec. 32, T.32N., R.2W.; north side Clover Creek: (P50-36) 
Str. position: Member IV

Fossil: Eupachydiscus aff. E, teshioensis (JiMBo)

Age: Senonian

Coll.: W. P. Popenoe

UCLA. 3784

Area: Millville Quad. (Redding area), Shasta Co., NE. Sacramento Valley

Loc.: $\quad 0.4$ mile S. $42^{\circ} \mathrm{W}$. of the NE. corner of sec. 7, T.32N., R.1W.; in dark, calcareous concretion in soft gray shale, on hill slope 100 yards east of Clover Creek and 100 yards north of small iron-roofed shack

Str. position: Member V (?) (possibly Member IV)

Fossil: Baculites capensis WooDs

Age: Lower Senonian

Coll.: W. P. Popenoe \& Victor Church, 7/31/1936

UCLA. 3785

Area: Millville Quad. (Redding area), Shasta Co., NE. Sacramento Valley

Loc.: Just south of the N. line of sec. $27, T .32 N$., R.2W.; where the line crosses the creek, in Clover Creek: (P61-36)

Str. position: Member VI

Fossil: Inoceramus orientalis ambiguus NAGAO \& MATSUMoto

Age: Upper Santonian

Coll.: W. P. POPENOE, 8/2/1936

UCLA. 3786

Area: Millville Quad. (Redding area), Shasta Co., NE. Sacramento Valley

Loc.: NW. $1 / 4$ of SE. $1 / 4$, sec. 34 , T.32N., R.2W.; a small tributary of north side of Old Cow Creek: "70"

Str. position: Member VI

Fossil: Inoceramus orientalis ambiguus NAGAo \& MATSUMoto (typical)

Age: Upper Santonian

Coll.: W. P. POPENOE

UCLA. 3787

Area: Millville Quad. (Redding area), Shasta Co., NE. Sacramento Valley

Loc.: About 2000 feet E. \& 500 feet N. of SW. corner, sec. 35, T.32N., R.2W.; dark grey siltstone, left bank of gully tributary to Old Cow Creek from east: (63SacR2-94)

Str. position: Member VI

Fossil: Inoceramus orientalis ambiguus NAGAo \& MATSUMoto

Age: Upper Santonian

Coll.: W. P. Popenoe, 8/21/1957

UCLA. 3788

Area: Millville Quad. (Redding area), Shasta Co., NE. Sacramento Valley

Loc.: Approximately center of NW. $1 / 4$, SE. $1 / 4$, sec. 17, T.32N., R.2W.; slightly east of due north from Hunt ranch house, in shale exposure in a gully north of road

Str. position: Member IV

Fossil: Eupachydiscus aff. E. teshioensis (JimBo) (crushed)

Age: Lower Senonian

Coll.: W. P. Popenoe, July 1936

UCLA. 3789

Area: Millville Quad. (Redding area), Shasta Co., NE. Sacramento Valley 
Loc.: 300 feet E. and 2000 feet S. of NW. corner, sec. 4, T.32N., R.2W.; Swede Creek (French Creek on map), about 500 feet N. of CIT. 1345 (P25-36) (Romaniceras locality) on west bank of Creek

Str. position: Member III (higher part according to PoPENoE, but doubtful; could be lower part, T. M.'s opinion)

Fossils: Hyphantoceras sp., Scaphites sp., Otoscaphites cf. puerculus (Jімво)

Age: Turonian (?)

Coll.: Dick SAUL, summer 1954

UCLA. 3790

Area: Millville Quad. (Redding area), Shasta Co., NE. Sacramento Valley

Loc.: From bluffs on south side of Hooten Gulch, about 1/8 (?) mile upstream east of the power house, eastern end of South Cow Creek

Str. position: Member V, upper part

Fossil: Pseudoschloenbachia aff. P. boulei (BASSE)*

Age: Upper Santonian (or Lower Campanian)

Coll.: W. P. Popenoe, 1936

UCLA. 3791

Area: Millville Quad. (Redding area), Shasta Co., NE. Sacramento Valley

Loc.: Approx. 1000 feet E. and 2000 feet N. of SW. corner, sec. 5. T.31N., R.1W.; about 3000 feet upstream from loc. UCLA. 3790, near loc. SOC. K-229, Hooten Gulch at 920 feet (float), South Cow Creek Valley

Str. position: Member V (upper part)

Fossil: Hyphantoceras venustum (YABE)

Age: Santonian

Coll.: W. P. Popenoe

UCLA. 3792

Area: San Antonio del Mar, Baja California, Mexico

Loc. and Str. position: JoHnson's ranch; concretionary beds below oyster reef and about 1 mile upstream from the arroyo mouth: (P3-48); about same (?) stratigraphic position as loc. UCLA. 3795

Fossils: Baculites aff. $B$. occidentalis MEEK (rather intermediate between typical $B$. occidentalis and Eubaculites ootacodensis) (see Part I, p. 155), associated with a rudistid

Age: Upper Campanian or Lower Maestrichtian

Coll.: W. P. Popenoe, Harold Stager, \& Gordon WeIr

UCLA. 3793

Area: Paradise Quad., Butte Co., E. Sacramento Valley

Loc.: "Fossiliferous concretions in a narrow gully in sandstone bluff downstream from Centerville bridge approx. 1000 yards and on east side of stream, Butte Creek: (SS-1-54)

Str. position: Chico formation (relatively upper part)

Fossil: Canadoceras newberryanum (MEEK)

Age: Campanian

Coll.: R. B. SAUL, $7 / 25 / 1954$

UCLA. 3794

Area: Millville Quad. (Redding area), Shasta Co., NE. Sacramento Valley

Loc.: NW. $1 / 14$ of SE. $1 / 4$ of sec. 5, T.31N., R.1W.; upper part of Hooten Gulch, 3/4 mile above the power house: (P63-36)

Str. position: Member V (near top) (?); "shales and interbedded sandstone below 
massive sandstone"

Fossils: Baculites sp. indet. (cf. B. bailyi WooDs), Inoceramus naumanni YokoYAMA,

Inoceramus cf. cordiformis SOWERBY

Age: Santonian

Coll.: W. P. Popenoe, 8/6/1936

UCLA. 3795

Area: San Antonio del Mar, Baja California, Mexico

Loc.: JoHnson's ranch, about 35 miles a little east of south of Santo Tomas; concretions in thin-bedded soft sandstone outcropping just north of the ranch building in a shallow gully, near old distillery site: (P2-48)

Str. position: Lower than UCLA. 3796

Fossil: Inoceramus cf. ezoensis YoKoYama

Age: Senonian

Coll.: W. P. Popenoe, Harold Stager, \& Gordon Weir

UCLA. 3796

Area: San Antonio del Mar, Baja California, Mexico

Loc.: JoHNSON's ranch; concretionary boulders at base of sea-cliff about 6500 feet N. of mouth of Arroyo San Antonio

Str. position: Probably highest Cretaceous beds of this area

Fossil: Inoceramus cf. shikotanensis NAGAo and MATSUMoto [ $=I$. pacificus ANDERSON and HANNA, non WooDs]

Age: Lower Maestrichtian

Coll.: W. P. Popenoe, Harold Stager, \& Gordon Weir

UCLA. 3956

Area: Los Angeles Co., Santa Monica Mts., S. California

Loc.: Quarry in Santa Ynez Canyon, 1.75 miles north of Pacific Coast highway (US. 101, Alternate)

Str. position: Sandstone in the fourth member

Fossils: Eupachydiscus n. sp. (?) aff. E. lamberti CoLLIGNoN

Age: Campanian

Coll.: W. P. Popenoe 


\section{Concluding Remarks}

\section{Classification}

The systematic descriptions in Parts I and II have dealt with almost all the important representatives of the Upper Cretaceous ammonoid faunas of California, although they do not completely cover the entire faunas. Several species, such as those belonging to Placenticeratidae and Scaphitidae, have been only briefly mentioned, simply because the period of my stay in California was too short for completing the full description.

Broadly speaking the ammonites at my disposal fall within the general scheme of classification recently compiled by ARKELL and WRIGHT (in MOORE [Editor], 1957). In other words they all belong to already established genera, and no new generic names are required for any of them, except for one doubtful case. This is Eucalycoceras (?) shastense (REAGAN), which may represent a new genus but for which I have not proposed a new name.

Although ANDERSON (1958) has recently established seven new genera, Neokotoceras, Joaquinites, Eocanadoceras (as a subgenus), Oregoniceras, Butticeras, Exicrioceras, and Neocyrtochilus, they fall in the synonymy respectively of Damesites, Pachydiscus, Jimboiceras, Subprionocyclus, Submortoniceras, Exiteloceras (?), and Polyptychoceras (?). The doubts about the synonymy of the last two genera are due to the incompleteness of ANDERSON's material. Graysonites (ADKINS MS.) Young (1958), a recently validated genus, is also confirmed in this paper from the Californian material.

At the specific level, I have established only two new species, Baculites schencki and Baculites kirki, and introduced one new name Acanthoceras whitei. Among a great number of new specific names which ANDERson (1902, 1931, 1958) proposed several are of value, subject to some necessary revision. Examples are Subprionocyclus branneri (ANDERSON), S. normalis (ANDERSON), Patagiosites arbucklensis (ANDERSON), Baculites rex ANDERSON, and B. lomaensis ANDERSON. Many others, however, prove to fall in the synonymy of already established species and others were based on material insufficient to allow adequate revision.

These remarks may give the impression that F. M. ANDERSON was a splitter and that I am a lumper. I am never in favor of too gross lumping, but have endeavoured to classify the ammonites in as natural and reasonable a way as possible, in faict to adopt a moderate course. In this respect I agree with KUMMEL $(1954$, p. 184) in the general statement that "in the past few years very few new genera have been established in spite of the fact that several large new faunas have been described" and that "possibly we are near the limit of the total number of ammonoid genera in the order of approximately 1800."

From the study of the ammonites from California and other areas of the West Coast, taxonomic improvement has been accomplished for certain genera or species groups. A concise summary of results is as follows: 
(1) Phylloceratidae.-Neophylloceras SHIMIZU, as redefined by WRIGHT and Matsumoto (1954), is distinguished from Hypophylloceras SALFELD by the much more finely incised and multipartite sutures. The type-species, N. ramosum (MEEK), is proved to range, as in Japan, from Turonian to Campanian. The Upper Albian-Cenomanian species, N. seresitense (PERVINQUIÈrE), has some intermediate features between Hypophylloceras and Neophylloceras, but can well be referred to the latter, as I have discussed in detail in another paper of some Alaskan ammonites (MATsumoto, 1959a). Hyporbulites BREISTROFFER has, thus, been synonymized with Neophylloceras, and Neophylloceras is certainly a direct derivative from Hypophylloceras.

(2) Desmoceratidae. - Examples of Desmoceras (s.s.), Desmoceras (Pseudouhligella), Desmophyllites, Damesites, Puzosia, Mesopuzosia, Jimboiceras, Pachydesmoceras, and Hauericeras from California have been described. They all belong to already established species. No particular amendment is needed to the generic definitions which I gave previously (MATsumoto, 1954a; 1954b; MATSUmoto and ОватA, 1955).

Although ANDERson (1958) assigned several species to Parapuzosia, they are not true Parapuzosia but should be regarded as examples of other genera, such as Mesopuzosia, Pachydesmoceras, Hulenites, and Patagiosites. Puzosia (Austiniceras) giganteum ANDERSON (1958) is possibly to be referred to Parapuzosia (Austiniceras)*, although the holotype is imperfectly preserved.

(3) Muniericeratidae. - Tragodesmoceras ashlandicum (ANDERSON), emended in this paper, has some peculiar features when it is compared with the type-species, T. clypealoide (LEONHARDT), and T. clypeale (SCHLÜTER). Whether Tragodesmoceras is intimately related to the members of Desmoceratinae or to Puzosiinae is questionable. More material from various parts of the world is needed to make clear the relationships of Tragodesmoceras with other genera.

(4) Pachydiscidae.-There are representatives of Eupachydiscus, Anapachydiscus, Pachydiscus (s.s.), Pachydiscus (Neodesmoceras), Canadoceras, and Patagiosites in California and other parts of the West Coast. Patagiosites is certainly derived from Canadoceras. The existence of Patagiosites in California and Japan is to be expected, because Canadoceras occurs commonly there. Anapachydiscus gave rise to Pachydiscus (s.s.) and P. (Neodesmoceras), because there are transitional species. In connection with the origin of Eupachydiscus it is emphasized that $E$. aff. teshioensis (JIMBO), from the Coniacian of California, resembles certain species of Lewesiceras.

(5) Kossmaticeratidae.-Brief remarks have been given in Part II about the representatives of Hulenites, Marshallites, Eogunnarites, Kossmaticeras, and Pseudokossmaticeras from California. No alteration is needed to the definitions of these genera which I gave previously (MATsumoto, 1955b).

* Through the study of the recent collections I have confirmed that Puzosia (?) ambigua Matsumoto, 1954 is a good example of Parapuzosia (Austiniceras) in the Japanese Upper Cenomanian. 
(6) Acanthoceratidae.-Examples of Graysonites, Mantelliceras, Calycoceras, Acanthoceras, Kanabiceras, Romaniceras, and Eucalycoceras (?) from California and Oregon have been described. The last one is represented by $E$. (?) shastense (REAGAN). It is a multituberculate Eucalycoceras, as "Romaniceras" indiduraense JONES is, and accordingly might require a new generic name.

From the available evidence I have confirmed the close affinity of Graysonites with Sharpeiceras and Mantelliceras. The intimate relationship between Kanabiceras and Euomphaloceras has also been confirmed. The group of Acanthoceras amphibolum, a horned group, should be included in Acanthoceras, because it cannot really be separated from the rhotomagense group.

(7) Vascoceratidae.-I agree with BARBER (1957) in the definition of Plesiovascoceras and in the assignment of Fagesia californica ANDERSON to Plesiovascoceras.

(8) Collignoniceratidae.-Representatives of Collignoniceras, Subprionocycloceras, Prionocycloceras, Peroniceras, Texanites, Submortoniceras, and Pseudoschloenbachia occur in California and Oregon.

The definition of Collignoniceras by WRIGHT (in MOORE [Editor], 1957) is confirmed by the American material. In connection with the description of a species from California and Oregon, C. woollgari (MANTELL), the type-species, has been reexamined with the results that Schloenbachia bakeri ANDERSON is regarded as probably identical with $C$. woollgari.

I have redefined Subprionocyclus, including Oregoniceras ANDERson as a synonym, with a discussion on the relationship between Subprionocyclus and Collignoniceras. S. branneri (ANDERSON) has somewhat intermediate features between the two genera. Through the study of specimens from California and Oregon, S. neptuni (GEINITZ), the type-species, has been redefined with the results that several of ANDERSON's species are synonymized with S. neptuni. Another species, $S$. normalis (ANDERSON), is regarded as intermediate between Subprionocyclus and Reesidites.

Submortoniceras shows great variability, as verified by American and other examples. In connection with this I have proposed to transfer Delawarella, as a subgenus, to Submortoniceras from Menabites. Many of ANDERson's species have proved to be synonymous with $S$. (Submortoniceras) chicoense (TraSK).

So far as the Californian material is concerned, there is no need of significant alteration to the definition of Prionocycloceras, Peroniceras, Texanites, and Pseudoschloenbachia.*

(9) Placenticeratidae.-Proplacenticeras sp. has recently been reported from the Upper Albian (?) of southeast Alaska (MATsumoto, 1959a), but no Californian examples of Proplacenticeras and Placenticeras are known. In the higher part, probably Upper Campanian, Metaplacenticeras occurs abundantly.

* There is, in addition, a probably new, Texasia like ammonite came from loc. UCLA. 3369, Member $\mathrm{V}$ of the Redding area (Coll. Victor Church \& W. P. Popenoe). It is, however, represented by insufficient material for description. 
This genus is gain variable, as is exemplified by $M$. pacificum (SMITH), typespecies, and related species. The subgenus Paraplacenticeras, which was established on a Japanese species, M. subtilistriatum (JIMBO), has been suppressed as a subjective synonym of Metaplacenticeras, because the distinction between the Japanese and Californian species are not more than specific.

(10) Tetragonitidae. - Representatives of Anagaudryceras, Gaudryceras (s.s.), G. (Vertebrites), Zelandites, Tetragonites, and Pseudophyllites are found in California and adjacent areas.

To make the definition clear I have given remarks on Anagaudryceras in my paper of Alaskan ammonites (MAтsumoto, 1959a, p. 73), listing Paragaudryceras in the synonymy of Anagaudryceras.

Vertebrites is better treated as a subgenus of Gaudryceras, because the distinction is not great and because it is intimately connected with Gaudryceras (s.s.) through such a species as G. tenuiliratum (YABE).

Similarly Saghalinites is a subgenus of Tetragonites. T. henleyensis ANDERsoN is apparently intermediate between Tetragonites (s.s.) and Saghalinites.

(11) Turrilitidae.-In California and Oregon there are examples of Pseudohelicoceras, Mariella (s.s.), M. (Plesioturrilites), Turrilites (s.s.), and $T$. (Euturrilites). The first genus is represented by a large species, $P$. petersoni (ANDERSON), which probably indicates Albian.

(12) Nostoceratidae.-There are representatives of Hyphantoceras, Bostrychoceras, Didymoceras, Nostoceras, Exiteloceras (?), Pseudoxybeloceras, and Solenoceras in California and other parts of the West Coast. I have proposed the removal of Pseudoxybeloceras from Diplomoceratidae to Nostoceratidae because of its intimate relationship with Neocrioceras.

(13) Diplomoceratidae.-In California there are good representatives of Glyptoxoceras and Ryugasella, but examples of Scalarites, Polyptychoceras, and Diplomoceras are fragmentary. The diagnostic characters of Glyptoxoceras are well shown by the Californian specimens of $G$. indicum (ForBes). I have explained the distinctions of Glyptoxoceras from Scalarites, Diplomoceras, and Polyptychoceras. The resemblance between Ryugasella and Lechites is an example of heterochronous homoeomorphy.

(14) Scaphitidae.-Several species of Scaphitidae occur in a limited stratigraphic section (Turonian and Coniacian) in California and Oregon. They belong to Scaphites and Otoscaphites. I have given only brief comments on ANDERSON's species.

(15) Baculitidae.-In California and related areas representatives of the baculitids are relatively numerous. I have arranged them in eighteen species of four genera, Lechites, Sciponoceras, Baculites, and Eubaculites. I regard the Baculitidae as a monophyletic family. The ultimate origin of the baculitids is probably in Hamites, as already mentioned by Spath (1941). The intimate relationships of Sciponoceras with the preceding Lechites on one hand and with the succeeding Baculites on the other have already been known (SPATH, 1941; WRIGHT in MOORE [Editor], 1957) and confirmed by the present study (Part I). 
Furthermore, through the study of the material from the West Coast, Eubaculites has proved to have descended directly from such a species as Baculites occidentalis MEEK.

The genus Baculites comprises a large number of species. In California and adjacent areas $I$ have recognized thirteen species, of which two are new. I hold that it is at present unwise to subdivide Baculites into subgenera or to separate from it other new genera, because the included species are intimately connected and because the morphological diversities are considerably complicated. As a general tendency the earlier species of Baculites have simpler sutures than the later, but there are some exceptions. Ribs, tubercles, and even a ventral keel appear already in some of the species of earlier ages (i.e. Coniacian and Santonian). Both the elliptical and egg-shaped cross sections are recognized in species of earlier and also later geological ages. The same applies to the degree of tapering. Regional differentiation may exist, but the species groups do not seem to show significant differences between the separate provinces. Many of the species from the West Coast are widespread, occurring also in other parts of the Indo-Pacific realm or in the Gulf Coast province. Some are closely related to the European or Western Interior provinces.

In summation Baculitidae is one of the most important groups of ammonoidea in the Upper Cretaceous. I hope the descriptions in Part I will serve as a step towards a further improvements of its natural classification.

\section{Distribution}

This article outlines a conclusion about the paleogeographic distribution of the Upper Cretaceous ammonites from California. Comparisons are attempted between California and other faunal provinces. The conclusion is approximate and preliminary, because the collecting procedures in California have been insufficient for analysing exactly the faunal constituents. Furthermore, there are still unexplored or less well investigated areas and I could not examine with the same degree of accuracy the ammonites from various parts of the world. In fact a conclusion from a survey of literature alone would not be the same as that from a study of the actual specimens. Nevertheless the present results can give approximately the characteristic features of the Upper Cretaceous ammonoid faunas of California.

(1) Cosmopolites.-If we examine the distribution of the Upper Cretaceous ammonites at generic level, it is to be noted that many genera show a world-wide distribution. Examples are Neophylloceras, Desmoceras, Desmophyllites, Puzosia, Hauericeras, Eupachydiscus, Anapachydiscus, Pachydiscus, Stoliczkaia*, Mantelliceras, Calycoceras, Acanthoceras, Romaniceras, Collignoniceras, Subprionocyclus, Peroniceras, Texanites, Submortoniceras, Mariella*, Turrilites, Scaphites, Sciponoceras, and Baculites.

Even at specific level there are several species which can be regarded as

\footnotetext{
* Stoliczkaia and Mariella occur also in the Upper Albian.
} 
nearly cosmopolitan. Examples among the described species from California are as follows, with indication of a geological age as known in Western Europe, a standard area:

Neophylloceras seresitense (PERvINQUIERE) [Upper Albian-Cenomanian]

Romaniceras deverioide (DE GRossouvRE) [Middle Turonian]

Collignoniceras woollgari (MANTELL) [Middle Turonian]

Subprionocyclus neptuni (GEINITZ) [Upper Turonian]

Turrilites costatus LAMARCK [Lower Cenomanian]

Turrilites acutus PASSY [Cenomanian]

Turrilites (Euturrilites) scheuchzerianus Bosc [Cenomanian]

Sciponoceras baculoide (MANTELL) [Cenomanian]

It is noted that they are Cenomanian and Turonian species. If we furthermore take into consideration the species whose representatives in separate regions are not quite identical but very closely allied (some being possibly of subspecific distinction), the number of world-wide elements will increase. Examples among the species from California (indicated on the left side) and the corresponding representatives in Europe (indicated on the right side) are as follows:

Calycoceras spinosum (Kossmat) : C. aff. spinosum [Middle Cenomanian]

Sciponoceras aff. bohemicum (FRITSCH) : S. bohemicum [Upper Turonian]

Hyphantoceras oshimai (YABE): H. reussianum (D'ORBIGNY) [ $" \prime]$ Pachydiscus egertoni (FORBES) : P. neubergicus (HAUER) [Lower Maestrichtian]

Baculites inornatus MEEK : B. vertebralis LAMARCK [Upper CampanianLower Maestrichtian]

Baculites aff. anceps LAMARCK: B. anceps [ " "

In addition to Cenomanian and Turonian species, some near the boundary of Campanian and Maestrichtian are included here.

Identity can also be considered probably between Subprionocyclus branneri (ANDERSON) and S. cristatum (BILlinghuRst) [from the Turonian of England] and between Peroniceras tehamense (GABB) and P. rousseauxi DE GrossouvrE [from the Coniacian of France]. This suggests that more examples of widespread species may be recognized in the future, although the evidence from various regions is at present insufficient.

There are some genera or species-groups which might be expected to be cosmopolitan but have not yet been discovered from California. Remarkable examples are Metoicoceras near the Cenomano-Turonian boundary, Barroisiceras in the Coniacian, Hoplitoplacenticeras in the Upper Campanian, and Sphenodiscus and Hoploscaphites in the Maestrichtian. This may be due either to incomplete collecting or to difference of major faunal province. Among the above Hoplitoplacenticeras occurs in Vancouver Islands but others are known neither in California nor in the related areas.

(2) Comparison with the Japanese faunas.--So far as the species at my disposal are concerned, those common to Japan and California (plus adjacent 
areas) constitute the highest percentage of the whole faunas. In the following list of species those with a mark $[\mathrm{J}>\mathrm{C}]$ are represented by a greater number of individuals in the Japanese province than in the Californian province, those with a mark $[\mathrm{J}<\mathrm{C}]$ occur more abundantly in California than in Japan, and those with a mark $[\mathrm{J}=\mathrm{C}]$ are regarded as occurring in the two provinces in nearly equal abundance. The stratigraphic range of the named species in the Japanese province is indicated in brackets with symbols:

$\mathrm{K} 3 \beta=$ Upper Miyakoan (Albian)

$\mathrm{K} 3 \gamma=$ Infragyliakian (lower Lower Cenomanian)

$\mathrm{K} 4 \alpha=$ Lower Gyliakian (main part of Cenomanian)

$\mathrm{K} 4 \beta=$ Upper Gyliakian (Turonian)

$\mathrm{K} 5 \alpha=$ Lower Urakawan (Coniacian)

$\mathrm{K} 5 \beta=$ Upper Urakawan (Santonian)

$\mathrm{K} 5 \mathrm{r}=$ Infrahetonaian (Lower Campanian)

$\mathrm{K} 6 \alpha=$ Lower Hetonaian (Middle and Upper Campanian)

$\mathrm{K} 6 \beta=$ Upper Hetonaian (Maestrichtian)

For the definition and international correlation of these Japanese stages the reader may refer to my previous papers (MAтsumoto, 1942-1943, 1954a, 1959b).

Neophylloceras seresitense (PERVINQUIÈRE) $[\mathrm{J}=\mathrm{C}][\mathrm{K} 3 \beta-\mathrm{K} 4 \alpha]$

N. ramosum (MEEK) $[\mathrm{J}=\mathrm{C}][\mathrm{K} 4 \beta-\mathrm{K} 6 \alpha, \mathrm{K} 6 \beta$ ? $]$

$N$. hetonaiense Matsumoto $[\mathrm{J}=\mathrm{C}][\mathrm{K} 6 \alpha-\mathrm{K} 6 \beta]$

Desmoceras kossmati Matsumoto [J $>\mathrm{C}]$ [K3r]

D. (Pseudouhligella) poronaicum $\mathrm{YABE}[\mathrm{J}>\mathrm{C}][\mathrm{K} 4 \alpha]$

D. (P.) japonicum YABE $[\mathrm{J}>\mathrm{C}][\mathrm{K} 4 \alpha]$

Desmophyllites diphylloides (FoRBES) $[\mathrm{J}=\mathrm{C}][\mathrm{K} 5 \gamma-\mathrm{K} 6 \alpha]$

Damesites damesi (JIMBO) $[\mathrm{J}>\mathrm{C}][\mathrm{K} 5 \alpha-\mathrm{K} 5 r]$

D. hetonaiensis Matsumoto* $[\mathrm{J}=\mathrm{C}][\mathrm{K} 6 \beta]$

Puzosia intermedia Kossmat $[\mathrm{J}=\mathrm{C}][\mathrm{K} 4 \beta]$

Mesopuzosia pacifica Matsumoto $[\mathrm{J}>\mathrm{C}][\mathrm{K} 4 \beta-\mathrm{K} 5 \alpha]$

M. indopacifica (Kossmat) $[\mathrm{J}=\mathrm{C}][\mathrm{K} 4 \beta-\mathrm{K} 5 \alpha]$

Jimboiceras planulatiforme (JIMBo) $[\mathrm{J}>\mathrm{C}][\mathrm{K} 4 \beta]$

Pachydesmoceras pachydiscoide MATSUмото [J $>\mathrm{C}][\mathrm{K} 4 \beta]$

Hauericeras (Gardeniceras) angustum $\mathrm{YABE}[\mathrm{J}>\mathrm{C}][\mathrm{K} 5 \beta$, also $\mathrm{K} 5 \gamma$ and ? $\mathrm{K} 5 \alpha]$

$H$. (G.) cf. rembda (ForBes) $[\mathrm{J}=\mathrm{C}][\mathrm{K} 6 \beta]$

Eupachydiscus haradai (JIMBO) [J>C] [upper K5 $\beta-\mathrm{K} 5 r]$

Anapachydiscus arrialoorensis (STOLICZKA) [J=C] [K5 $\beta$ ?-K6 $\alpha$ ?]

A. deccanensis (STOLICZKA)* $[\mathrm{J}>\mathrm{C}][\mathrm{K} 5 \beta]$

Pachydiscus (s.s.) cf. egertoni (FoRBES) $[\mathrm{J}=\mathrm{C}][\mathrm{K} 6 \beta]$

$P$. (s.s.) subcompressum Matsumoto $[\mathrm{J}>\mathrm{C}$ ] [upper $\mathrm{K} 6 \alpha-\mathrm{K} 6 \beta]$

Canadoceras yokoyamai (JIMBO) $[\mathrm{J}=\mathrm{C}][\mathrm{K} 6 \alpha]$

C. mysticum Matsumoto $[\mathrm{J}=\mathrm{C}][\mathrm{K} 6 \alpha]$

Marshallites n. sp. [J $>\mathrm{C}][\mathrm{K} 4 \alpha]$

Kossmaticeras aff. japonicum Matsumoto $[\mathrm{J}>\mathrm{C}][\mathrm{K} 5 \alpha-\mathrm{K} 5 \beta]$

Menuites ef. menu (FoRBES) $[\mathrm{J}=\mathrm{C}][\mathrm{K} 6 \beta, \mathrm{K} 6 \alpha$ ? $]$

Calycoceras spinosum (Kossmat) [J $>\mathrm{C}$ ] [middle $\mathrm{K} 4 \alpha$ ]

C. orientale Matsumoto, SAITo, and Fukada [J>C] [middle $\mathrm{K} 4 \alpha$ ]

C. stoliczkai Collignon $[\mathrm{J}=\mathrm{C}][\mathrm{K} 4 \alpha]$ 


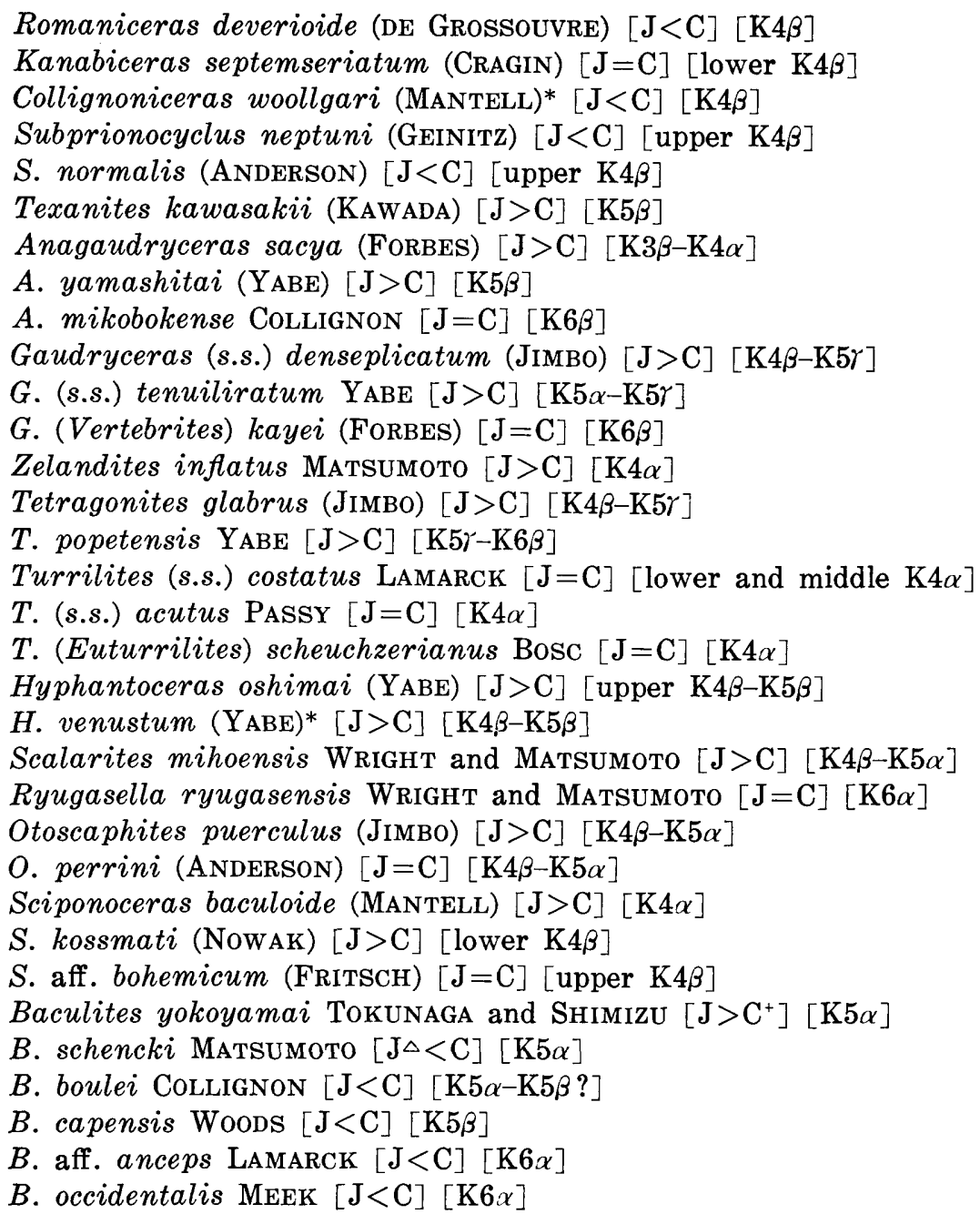

There are sixty-two species altogether. In the above list the species with a mark * may be represented by different subspecies in the two provinces. In addition there are about a dozen cases, as listed below, in which the corresponding representatives in the two provinces $([\mathrm{C}]$ and $[\mathrm{J}]$ ) are regarded as different but very closely allied.

Eupachydiscus aff. teshioensis (JIMBo) [C]: E. teshioensis [J] [K5 $]$

Pachydiscus (Neodesmoceras) catarinae (ANDERSON and HANNA) [C]: $P$. (N.) japonicus Matsumoto $[\mathrm{J}][\mathrm{K} 6 \beta]$

Canadoceras newberryanum (MeEK) [C]: C. kossmati Matsumoto [J] $[\mathrm{K} 6 \alpha]$

+ Read Baculites cf. yokoyamai for B. aff. B. yokoyamai in the explanation of Text-fig. 26 (page 118) in part I.

$\triangle$ Baculites schencki has quite recently been discovered in the zone of Inoceramus uwajimensis in Japan, although it is very rare. 
Marshallites voyanus (ANDERSON) [C]: M. olcostephanoides MATSUмото [J] [K4 $\alpha]$

Romaniceras aff. pseudodeverianum (JIMBO) [C]: R. pseudodeverianum (JimBo) $[\mathrm{J}][\mathrm{K} 4 \beta]$

Metaplacenticeras pacificum (SмIтH) [C]: M. subtilistriatum (JIMBo) [J] $[\mathrm{K} 6 \alpha]$

Zelandites sp. [C]: Z. kawanoi (Jімво) [J] [K5 $\beta-\mathrm{K} 6 \alpha]$

Bostrychoceras aff. otsukai (YABE) $[\mathrm{C}]:$ B. otsukai (YABE) $[\mathrm{J}][\mathrm{K} 5 \beta]$

Didymoceras hornbyense (WHITEAVES) [C]: D. awajiense (YABE) [J] $[\mathrm{K} 6 \alpha]$

Scaphites condoni ANDERSON [C]: S. planus YABE [J] [K4 $]$

S. gillisi ANDERSON [C]: S. pseudoaequalis YABE [J] [K4 $\beta-\mathrm{K} 5 \alpha]$

From the above lists the intimate connection between the faunas of California and Japan is evident in every age of the Late Cretaceous. There is of course some difference. Neopuzosia, Yokoyamaoceras, Reesidites, and Parajaubertella are common in the Japanese province, but no good representatives of them have been found in California; there are some examples of Tragodesmoceras, Plesiovascoceras, Pseudophyllites, and Eubaculites in California, but no examples of them have been confirmed to occur in Japan. This may be, however, due to insufficient collecting. The Japanese Cretaceous faunas contain such peculiar genera as Nipponites, Pravitoceras, Eomadrasites, and Mikasaites, which seem to be endemic according to our present knowledge. There is no known genus which is restricted to California or adjacent areas only.

The apparent difference may be due to ecological or sedimentary environment. Members of the Tetragonitidae, such as Tetragonites, Anagaudryceras, Gaudryceras, and Zelandites, and some of the Desmoceratidae, such as Desmoceras (Pseudouhligella), Damesites, and Mesopuzosia are persistent and occur abundantly in various stages of the Japanese Upper Cretaceous. They do occur in California but the occurrence is sporadic and restricted to particular beds. Polyptychoceras (of the Diplomoceratidae) is common in the Lower Senonian of Japan but is very rare in California. The Baculitidae are fairly common and occur at various levels in the Upper Cretaceous of California, being often predominant over other ammonites. In the Japanese Cretaceous they are not rare but never so abundant as the desmoceratids and tetragonitids. The Santonian in Japan is very prolific, while only a few species of ammonites have been collected from the presumably Santonian equivalent in California.

(3) Indo-Pacific elements.-A list of species indicated in the preceding paragraph as common to the Californian and Japanese provinces consists of the following elements :

(a) Cosmopolites, as mentioned in paragraph (1)

(b) Indo-Pacific elements, which are not only common to the northern Pacific provinces but also distributed over other parts of the vast Indo-Pacific realm

(c) Northern Pacific elements, which occur primarily in the northern Pacific region 
Some of the species which are temporarily included in group (c) may be removed to group (b) as our studies expand. Similarly some of the species of group (b) may be proved in the future to belong to group (a).

According to our present knowledge, Neophylloceras hetonaiense Matsumoto, Desmoceras kossmati MATsumoto, Desmophyllites diphylloides (ForBes), Puzosia intermedia Kossmat, Mesopuzosia indopacifica (Kossmat), Hauericeras (Gardeniceras) rembda (FORBES), Eupachydiscus haradai (JIMBO), Anapachydiscus arrialoorensis (STOLICZKA), A. deccanensis (STOLICZKA), Pachydiscus (s.s.) egertoni (FORBES), Menuites menu (FORBES), Calycoceras stoliczkai Collignon, Anagaudryceras mikobokense CoLLIGNON, Gaudryceras (s.s.) denseplicatum (Jімво), G. (Vertebrites) kayei (ForBes), Tetragonites glabrus (JIMBo), Sciponoceras kossmati (NowAK), Baculites yokoyamai ToKUNAGA and SHIMrZU [= ? B. besairiei CollignoN], B. boulei CollignoN, and B. capensis Woods, twenty species altogether, are the examples of Indo-Pacific elements among the listed species. Not a few of them extend further to the Mediterranean region.

In addition to the above species there are sixteen species from California which are identical with or very closely allied to species from southern India, Madagascar, southeast Africa, western Australia, New Zealand, etc., although their representatives in the Japanese province have not yet been confirmed. They are listed below, with indication of the geological age in Madagascar, southern India, western Australia or other areas.

Eupachydiscus sp. nov. (?) : E. lamberti CoLLIGNoN [Middle Campanian] Pachydiscus ootacodensis (STOLICZKA): itself [Maestrichtian or Upper Campanian]

$P$. (Neodesmoceras) catarinae (ANDERSON and HANNA) : $P$. (N.) mokotibense Collignon [Lower Maestrichtian]

Canadoceras sp. nov. (?): C. hoepeni Collignon [Campanian]

Kossmaticeras klamathone (ANDERson): K. pachystoma Kossmat

[Lower Senonian]

Calycoceras newboldi (Kossmat): itself [Cenomanian]

Acanthoceras whitei MATSUMOTo: itself [Cenomanian]

Submortoniceras chicoense (TRASK) : S. piveteaui Collignon, S. imlayi

Collignon, S. spathi Collignon, etc. [Lower or Middle Campanian]

Pseudoschloenbachia sp. nov. (?) : P. boulei (BASSE) [Lower Campanian]

Zelandites sp.: Z. kaiparaensis MARshall [Campanian]

Pseudophyllites indra (FORBES) : itself [Campanian and Maestrichtian]

Glyptoxoceras indicum (FORBES): itself [Upper Campanian or Lower

Maestrichtian]

G. subcompressum (FORBES): itself [ " $"$ " ]

Diplomoceras notabile (WHITEAVES) : itself; D. tenuisulcatum (FORBES)

[ " " $"$ ]

Baculites (?) aff. teres (FORBES): B. (?) teres (FoRBES) [ $" \prime \prime \prime]$

Eubaculites ootacodensis (STOLICZKA) : itself [ $" \prime \prime \prime$ ]

Even among the species belonging to the northern Pacific region (group c) 
there are several which have some affinity with other Indo-Pacific species. Hauericeras (Gardeniceras) angustum YABE, for instance, is allied to but well distinguished from $H$. (G.) gardeni (BAILY); Pachydiscus subcompressus Matsumoto resembles Pachydiscus compressus (SPATH).

As there are many insufficiently investigated areas in the Indo-Pacific realm, it is at present difficult to tell along what route a given species migrated and how it changed during the migration. Neophylloceras hetonaiense MATSUмото, for instance, has been reported as occurring in Japan, California, and Graham Land of Antarctica. The last area is very distant from the first two, but there are at present no available records of this species from the Pacific side of South America, New Zealand, New Caledonia, or New Guinea. Submortoniceras chicoense (TRASK), which occurs abundantly in the upper part of the Chico formation in the Chico area of California, is closely allied to certain species from the Lower or Middle Campanian of Madagascar. The two areas are much separated, but no allied species have been described from southern India, western and northern Australia, Japan, Alaska, or even from British Columbia. Japan and Sakhalin do have some representatives of Submortoniceras, but they are atypical, being allied to ancestral Protexanites or Texanites. Thus there is much to be done to trace exactly the relationships of the faunal elements among various provinces of the Indo-Pacific realm.

(4) Relationship with the faunas of the Gulf Coastal province.-The species common to California and the Gulf Coastal province are few and those common to California and the Wastern Interior province are very few. This is evidently due to the paleogeographic condition that a great barrier had arisen in consequence of the Nevadan movements. How far the barrier extended and how long it continued to play a role in separating the two major marine regions of North America are questions to be studied.

YouNG (1958) has recently described four species of Graysonites from the Lower Cenomanian of Texas. I have recognized one of them, G. wooldridgei Young, in the collection of M. V. KIRK from California and another, G. lozoi. Young, from Kyushu and Hokkaido in Japan. As I have discussed in the paleontologic description, Graysonites is intimately related to Sharpeiceras and a specimen from Baia California is allied to Graysonites wooldridgei on one hand and to "Sharpeiceras laticlavium var. mexicanum BösE" from northeastern Mexico on the other. This gives suggestions not only about the systematic position of Graysonites but also about the route of its migration. In view of the world-wide distribution of Stoliczkaia, Mantelliceras, and Sharpeiceras, I presume as a possibility that Graysonites might be distributed much more extensively than we know at present.

Another noteworthy species is Kanabiceras septemseriatum (CRAGIN). It occurs very commonly at the basal Turonian in Texas and extends up to the Western Interior province. Examples of the same species have been recognized in California and furthermore in Japan. According to WRIGHT (1957 in MOORE [Editor], p. L414; also personal communication, October 1959) it is widespread 
in England and probably elsewhere in Europe. Therefore this species may be better regarded as a world-wide species rather than an example of TexasCalifornian connection.

Romaniceras loboense ADKINs, from the Turonian of Texas, has proved to be identical with $R$. deverioide (DE GRossouvRE) which occurs in California, Japan, Madagascar, Syria, Algeria, and France. Collignoniceras woollgari (MANTELL) is another world-wide species of Middle Turonian. It occurs in California, Texas, and the Western Interior province too.

Another epoch of connection between the two regions may be early Maestrichtian or latest Campanian. Baculites columna MoRTON occurs in the Maestrichtian Prairie Bluff chalk of Alabama and the Corsicana marl (Navarro group) of Texas. I have recognized several examples of them in California. B. sp. of STEPHENSON (1941, p. 406, pl. 76, figs. 7, 8) from the Neylandville marl (Navarro group) of Texas is almost indistinguishable from B. lomaensis ANDERSON from the San Joaquin Valley and near La Jolla of California. B. claviformis STEPHENsoN from the Navarro group is closely allied to a bluntly costate variety of $B$. inornatus MEEK from the West Coast. Solenoceras mexicanum ANDERSON from Baia California and San Joaquin Valley is indistinguishable from $S$. reesidei STEPHENSON from the Navarro group. Turrilites excelsus ANDERSON from California is, in my opinion, identical with Nostoceras splendidum (SHUMARD) from the Nacatoch sand (Navarro group) of Texas.

Thus there seems to have been intermittent connection between the two regions. The question then arises of the route of such connection. In addition to Mexico, that I have suggested above, Arizona, New Mexico, and Trans-Pecos Texas should be investigated. They contain some interesting ammonites, but I do not think that the Cretaceous faunas of these areas have been fully explored.

(5) A summary of results.-From the above analysis I am led to a conclusion that the Upper Cretaceous faunal province of California and adjacent areas is most intimately connected with the Japanese province, considerably related to other parts of the Indo-Pacific provinces, probably intermittently influenced from the Gulf Coastal province, and presumably indirectly related to Europe and other far distant parts. Many ammonoid genera have a world-wide distribution and even at specific level cosmopolites are recognized more frequently in the Cretaceous ammonites than in the mollusca of the present sea. I expect that the students in other groups of Cretaceous faunas, such as foraminifera and inocerami, would come to a similar conclusion.

The reason for this fact is not clear but remains to be studied. Presumably the factors concerned would have been more than one. Ammonoidea led generally an active life that would have given them a good chance of extensive distribution. The late Cretaceous was a period of major marine transgression which would have resulted in relatively uniform and mild climate as well as free interregional communication. We know little about the marine conditions of the oceans in the Cretaceous Period or about the life history of ammonites. In this paper, however, I do not intend to go too far into the problem. 
(6) Local conditions.-The faunal analysis attempted above is on a broad scale, ignoring the ecological and sedimentary conditions which must have changed from place to place and from time to time.

I have mentioned in paragraph (2) the relative abundance of the Baculitidae and poor representation of the Tetragonitidae and Desmoceratidae in the Cretaceous sediments of California compared with those of Japan. This is probably to be explained from ecological and sedimentary conditions rather than from geographic distribution. Siltstones containing calcareous concretions predominate in the Upper Cretaceous of Hokkaido where the phylloceratids, desmoceratids, and tetragonitids occur commonly throughout the sequence. Fossils belonging to these groups do occur in the Californian sequence; they are indeed fairly common in the Lower Cretaceous Horsetown group, but their occurrence becomes discontinuous, sporadic, or even solitary in the Upper Cretaceous in which conglomerates and sandstones (greywackes) are frequently intercalated with the shales.

Baculitids occur more frequently than the tetragonitids and desmoceratids in the Upper Cretaceous of California, if not so continuously and abundantly as in the Montana group of the Western Interior province. They can be found from both the muddy and sandy rocks. In the latter case they may occur in abundance, being often arranged in subparallel orientation. This suggests the effect by transportation or movement by the water body. In view of the difference in apertural character I do not think the habitats of Sciponoceras and Baculites are identical. In fact Sciponoceras is less common in California than in Hokkaido, although I cannot satisfactorily explain the reason. Baculites rex ANDERSON is characterized by its large size; the largest example came from the Debris Dam sandstone, but the examples from the Moreno shale are all small. This may or may not be due to difference in habitats between mature and immature forms. Allison (personal communication) observed a similar feature in the case of Baculites inornatus (MEEK) from Baja California.

If we observe the occurrence of various groups of ammonites in more detail, we shall be able to read some records concerning local paleogeography and its historical change. For this purpose my observations are obviously insufficient and the evidence from various other sources is needed. I can give here only a few notes.

There is a considerable difference in the stratigraphic sequence, sedimentary facies, and thickness of the Cretaceous rocks between the east and west sides of the Great Valley of California. Generally speaking, the Upper Cretaceous rocks on the east side of the Sacramento Valley are of shallow sea environments, probably representing the marginal part of the sedimentary basin. As can be seen in the Chico and Redding areas, fossils occur fairly commonly throughout the sequence. They are often embedded in more or less calcareous sandstones in which pelecypods and gastropods are predominant over ammonites. Their preservation is generally good, probably because of a less intense tectonic deformation, the competency of the calcareous sandstone, and a smaller load of 
sediments. Ornate ammonites, such as Romaniceras deverioide (DE GRossoUVRE), Subprionocyclus neptuni (GEINITZ), S. normalis (ANDERSON), and Submortoniceras chicoense (TRASK), have been obtained fairly abundantly from this part of California.

On the west side of the Great Valley the Upper Cretaceous sediments are very thick, consisting of alternating beds, lentils, members, or formations of shales and sandstones, with local conglomerates. Megafossils are generally poor, occurring very sparsely or being limited to particular beds. Some of the ornate ammonites do occur, but are poorly preserved; others are rare or almost absent. Relatively well preserved ammonites have been found in limy concretions contained in particular, silty formations, such as the Forbes formation on the west side of the Sacramento Valley and the Ragged Valley formation ( $\|$ the so-called Pachydiscus silt) on the west side of the San Joaquin Valley. In other cases more or less fragmentary ammonites are scattered in particular parts of sandstones or conglomerates, associated with other shells, or highly crushed ammonites occur in a limited thickness of shales, or a solitary ammonite may be found at an isolated locality. Barren beds occupy much thicker parts of the sequence.

The Upper Cretaceous sequence in the Hornbrook and adjoining areas of northern California-southwestern Oregon and also in the Santa Ana Mountains and vicinities of southern California consists partly of prolific members of the sandy rocks and partly of poorly fossiliferous or almost barren thicker members. The prolific beds are characterized by rich molluscan shells in which ammonites occupy a smaller percentage. Metaplacenticeras pacificum (SMITH), Subprionocyclus neptuni (GEINITZ), S. normalis (ANDERSON), and certain other ornate ammonites occur in these beds too.

So far as the evidence of ammonites is concerned, there seems to be no significant difference in faunal province between northern and southern California. Even if the sedimentary basins may have been separated at certain epochs, they must have had free communication directly or indirectly by way of the open sea. In the Cenomanian the marine area extended to central Oregon, although the paleogeography is not known in detail. In the late Senonian the faunal connection was intimate between the sedimentary basins of California and Vancouver Islands (British Columbia). An apparent distinction that Hoplitoplacenticeras is absent in the former and Submortoniceras and Metaplacenticeras are absent in the latter is presumably due to some local ecological and sedimentary conditions, but might be due to incomplete collecting.

\section{Correlation}

(1) Basic foundation.-As I have shown in a historical review in the first chapter of this paper (Introduction in Part I) much has been done concerning the stratigraphy of the Upper Cretaceous in California. Detailed mapping, fine stratigraphic subdivision, collecting fossils from the measured sections, 
and zonation on the basis of a thorough paleontologic work are, however, indispensable for precise correlation. In these respects the present situation in California is far from complete. Be that as it may, I have endeavoured to go a step forward from the standpoint of ammonites.

As I have briefly summarized in the preceding paragraph, the stratigraphic occurrence of ammonites in the Upper Cretaceous of California is generally discontinuous and rather sporadic. There is no single standard section where the succession of Upper Cretaceous ammonites in California is completely recorded. The Cretaceous areas northeast of Redding and Chico on the east side of the Sacramento Valley give us relatively continuous records of ammonites, but the sequence is unfortunately incomplete, ranging over only a portion of the Upper Cretaceous. More complete sequence is exposed on the west side of the Great Valley, such as in the Panoche Hills and vicinities and the Rumsey Hills and adjacent areas, but ammonites occur at irregular intervals. It is hoped that northern California-southwestern Oregon are fairly suitable for our purpose, but their data are still incomplete.

Under these circumstances I have to summarize the succession of ammonites from various local records. As the local successions are more or less complementary to one another, a compilation is possible. I have described the stratigraphic data of each area, listing species of ammonites of my identification, in the chapter Notes on Stratigraphy. Species of Inoceramus have also been listed, because they are often associated with ammonites and because they are as useful as ammonites for regional as well as local correlation.

As I have mentioned in the preceding article (with the subtitle of Distribution), many species are common to California and Japan or at least very closely allied between the two provinces. In Japan a workable stage and zone classification has been established on the basis of ammonites and inocerami and the Japanese stages and zones are correlated with those of the international scale (see Matsumoto, 1959b). Thus the recently established Japanese scheme is a good foundation for the age determination of the ammonite-bearing beds in California. Certain species in California are identical with or closely allied to those in Madagascar, southern India, Texas, and Europe. They are likewise useful for world-wide correlation. Of course some species may have different stratigraphic ranges in California and in other region. This claims careful consideration of the assemblage and succession of species, as well as of effects of local ecological and sedimentary conditions.

(2) Suggested guide species.-Zonation on the basis of ammonites has not yet been accomplished in the Upper Cretaceous of California, because the necessary field work such as detailed mapping, measuring sections, and zonal collecting have been insufficient. From the available records, however, I can point out about thirty species of ammonites which seem to be practically useful for the age determination of strata. I suggest that they would become zonal indices, if the zonation be established.

The suggested guide species consist of two groups. One is a series of 
ornate ammonites most of which have a wide geographic distribution and a short stratigraphic range. They are useful for world-wide correlation, although a few of them are known only in California and are comparable to allied species in other provinces. They are as follows:

Graysonites wooldridgei Young [Lower Cenomanian]

Mantelliceras spp. [Lower Cenomanian]

Calycoceras orientale Matsumoto, SAIto, \& Fukada-

C. newboldi (Kossmat) [Middle Cenomanian]

Calycoceras boulei COLLIGNON-

C. stoliczkai Collignon [Middle or Upper Cenomanian]

Kanabiceras septemseriatum (CRAGIN) [Basal Turonian]

Plesiovascoceras californicum (ANDERSON) [Lower Turonian]

Collignoniceras woollgari (MANTELL) [Middle Turonian]

Romaniceras deverioide (DE GROSsoUvRE) [Middle Turonian]

Subprionocyclus neptuni (GEINITZ) [Upper Turonian]

Subprionocyclus normalis (ANDERSON) [Upper Turonian]

Peroniceras tehamense (GABB) [probably Coniacian]

Prionocycloceras californicum (ANDERSON) [probably Coniacian]

Texanites kawasakii (KAWADA) [Upper Coniacian-Lower Santonian ?]

Pseudoschloenbachia aff. boulei (BASSE) [Upper Santonian-possibly ranging up to Lower Campanian ?]

Submortoniceras chicoense (TRASK) [Lower Campanian-possibly ranging up to a part of Middle Campanian ?]

Metaplacenticeras pacificum (SмITH) [probably Upper Campanian]

Good indicators of the Maestrichtian such as Sphenodiscus lenticularis (OWEN), Hoploscaphites constrictus (SoWERBY), and Discoscaphites conradi (MORToN) or their allies have not yet been found in California. Hoplitoplacenticeras vancouverense (MEEK) of the Upper Campanian, Submortoniceras (Delawarella) delawarense (MORTON) of the Middle Campanian, Texanites texanus (RöMER) of the Lower Santonian, Protexanites bourgeoisi (DE GRossouVRE) and Barroisiceras spp. of the Coniacian, Utaturiceras vicinale (STOLICZKA) of the uppermost Cenomanian, Calycoceras naviculare (MANTELL) of the Upper Cenomanian, and Mantelliceras martimpreyi (CoQUAND) of the basal Cenomanian are also to be searched for.

The relative stratigraphic order of the above species is indicated in a chart (Plate 1). When it is clearly shown in the hitherto investigated Californian sequence, a boundary of successive species is drawn with a full line; when it is presumed from the indirect evidence, a boundary is drawn with a broken line.

The other group of suggested guide species is the Baculitidae. Species of the Baculitidae occur fairly commonly in California and related areas. Therefore they should be good zonal indices, if their stratigraphic occurrence in various sections is known more precisely and more frequently than at present. From the available records the succession of the baculitids in California may be summarized as follws (see PI. 1). 
(i) The age of Sciponoceras [Cenomanian and Turonian]

(a) S. baculoide (MANTELL) [Cenomanian]

(b) S. kossmati (NowAK) [primarily Lower Turonian, possibly Upper Cenomanian-Middle Turonian]

(c) S. aff. bohemicum (FRITSCH) [Upper Turonian]

(ii) The early age of Baculites [Coniacian and Santonian]

Species of Baculites which are characterized by a small size and a simple suture occur here. They are represented by $B$. yokoyamai Tokunaga \& Shimizu, B. schencki Matsumoto, B. boulei Collignon, $B$. capensis Woods, and $B$. kirki Matsumoto. Their ranges considerably overlap, but their relative order of appearance seems to shift in such a way as indicated in a chart (Pl. 1). At least two-fold subdivision on the basis of the following assemblage of species may be allowed.

(a) B. yokoyamai-B. schencki [Coniacian]

(b) B. kirki-B. capensis [Santonian]

$B$. cf. bailyi Woons may be accompanied by the latter.

(iii) The Middle age of Baculites [Campanian]

Species of Baculites characterized by a moderate size and suture of moderate complexity occur here. They are represented by $B$. chicoensis TRASK, B. inornatus MEEK, B. aff. anceps LAMARCK, and B. occidentalis MEEK. This age can be divided into two parts with the named species respectively.

(a) B. chicoensis [Lower Campanian]

(b) B. inornatus [Middle and Upper Campanian]

The latter part may be still more subdivisible, because $B$. aff. anceps and $B$. occidentalis seem to be restricted to its upper part. This need, however, further examination. $B$. aff. anceps and $B$. occidentalis are scarcely associated. They seem to have dissimilar niches, although they may be contemporary, but they might be slightly heterochronous.

(iv) The late age of Baculites [Maestrichtian]

B. rex ANDERson, which is typically large and has a very complicated suture, is characteristic of this age. Certain peculiar baculitids with reducing sutures and a small size may occur in this age, but they seem to have shorter ranges than $B$. rex. Their specific names are:

Baculites lomaensis ANDERSON

B. columna MORTON

B. (?) aff. teres ForBes

Eubaculites ootacodensis (STOLICZKA)

Locally they seem to be of use for further subdivision, but generally this is not yet certain.

The geological age indicated above in square brackets is determined from various kinds of evidence. Some of the named species have a world-wide distribution (see preceding article), in which case the geological age in terms of 
the international scale can be readily determined. Others are widespread in the Indo-Pacific realm, in which case the stratigraphic occurrence of the named species in Japan, Madagascar, or in southern India gives an approximate age on international scale. B. columna MoRToN is known, outside California, in the Prairie Bluff chalk of Alabama and Corsicana marl (Navarro group) of Texas, both of which are Maestrichtian. The stratigraphic positions of the species in California are of course taken into consideration, which are summarized in the other chart (Pl. 2). The assemblage of associated species is also considered. So far as is known, Baculites chicoensis TRAsK is endemic to California, but from its stratigraphic position above the beds with $B$. capensis and from the associated species, Submortoniceras chicoense (TRAsk), Canadoceras yokoyamai (ЈIMво), etc., the beds with $B$. chicoensis are regarded as the lower part of Campanian.

The prolific part of Baculites lomaensis ANDERSON and B. rex ANDERSON is certainly near the boundary line of Campanian and Maestrichtian from its stratigraphic position and the associated species, such as Damesites hetonaiensis fresnoensis (ANDERsoN), Hauericeras cf. rembda (FoRBES), Pachydiscus egertoni (FORBES), Pachydiscus (Neodesmoceras) cf. catarinae (ANDERSON and HANNA), Anagaudryceras mikobokense CoLLIGNON, Gaudryceras (Vertebrites) kayei (FORBES), etc. Whether this is Lower Maestrichtian or uppermost Campanian cannot be accurately determined, because these species are mostly Indo-Pacific elements and because the boundary problem is not firmly settled even in Western Europe.

In the Western Interior province CoBBAN (1951, 1958) has recently established an admirably fine zonation of the Upper Cretaceous. The Montana group is biostratigraphically subdivided on the basis of Baculites species. Because the faunal province is entirely separated, I do not think that the fine zones of the Western Interior province extend to California, but a parallel or corresponding relationship may be expected. CoBBAN's Western Interior scale is obviously much finer than the Californian scale presented in this paper. This may be due to the difference in the rate of evolution between the interior shallow sea province and the open and vast Indo-Pacific oceanic region. It is recalled, however, that CoBBAN and REESIDE (1952) once showed broader zones in the same Montana group than CoBBAN's (1958) recent ones. This amendment has come from refined stratigraphic and paleontologic work. For instance Baculites compressus SAY in a broad sense by COBBAN and REESIDE (1952) has now proved to be subdivided into five distinct species which occur successively at different levels. Baculites rex ANDERSON, which is similar to and probably parallel with $B$. compressus SAY, might be likewise subdivided in the future. Of course the two corresponding species may not be exactly contemporary, if they are not much separated in geological age.

The age of Sciponoceras could be more finely subdivided than the present scheme. WRIGHT (personal communication by a letter, Sept. 13, 1958) has informed me that the so-called $S$. baculoide (MANTELL) could be subdivided into 
at least two species of Lower and Upper Cenomanian respectively, but the Californian material at my disposal is not sufficient for realizing his idea.

I present in the same chart (Pl. 1) the succession of Inoceramus species which are associated with the ornate ammonites and baculitids. Many of them are identical with the species from Japan and Sakhalin, where the zonal succession of inocerami is well established (see Matsumoto, 1959b). Some others, such as Inoceramus crippsi MANTELL, I. labiatus SCHLOTHEIM, and I. cordiformis SowERBY, are world-wide. I. subundatus MEEK is very closely allied to $I$. balticus Вӧнм, a world-wide Campanian species.

(3) Associated ammonites.-In the right column of the same chart (Pl. 1) I indicate selected species of the associated ammonites. Some of them, such as Turrilites costatus LAMARCK [lower half of the Cenomanian], Didymoceras hornbyense (WHITEAVES) [Campanian, probably its upper half], and Patagiosites arbucklensis (ANDERSON) [Middle Campanian], have relatively short stratigraphic ranges, while most of others have long ranges, covering the whole of or more than one stage. Owing perhaps to the ecological and sedimentary conditions as well as to insufficient collecting their occurrence in California is limited to particular beds. The known stratigraphic position of the species occurring in California is approximately indicated in the chart by a symbol of black small circle. When the position is doubtful the black circle is not indicated. The true geological range of the species, which can be read from the Japanese and other sequences, is indicated by a long line in the chart.

Even if persistent species alone are given, the assemblage of several species can indicate a definite geological age. This has been well exemplified in the Japanese Cretaceous and will be workable also in the Californian Cretaceous. Of course the geological range of the species is not necessarily quite identical between the two provinces. Anapachydiscus deccanensis (STOLICZKA), for instance, is common in the Japanese Santonian, being represented by a subspecies A. deccanensis yezoensis Matsumoto, but in California, as in southern India and Madagascar, it occurs in the probably Campanian equivalent. Eupachydiscus haradai (Јıмво) characterizes the Upper Santonian and the Lower Campanian of Japan and Sakhalin, but probably ranges from the Lower to Upper Campanian on the West Coast, although it includes subspecies of slightly different ages. Eupachydiscus teshioensis (JІмво) occurs in the Lower and Upper Santonian in Japan, but a closely allied form, $E$. aff. teshioensis was obtained from probably Coniacian Member IV of the Redding area in California. The above examples are a few exceptions. In many cases the stratigraphic occurrence of ammonites in California is generally in harmony with that in Japan.

(4) A summary of international correlation.-From all the above mentioned guide species and associated ammonites we can tell approximately the geological age in terms of the international scale. My conclusion is indicated in a chart (Pl. 1). Because the biostratigraphic data are insufficient, it is unwise to propose provincial stage names, such as the Garzas, Quinto, Moreno, Los Gatos, Joaquin, Butte, Yolo, Bella Vista, Gaines stages of F. M. ANDERson (1943). This scheme 
is rather misleading in that it is not based on sound biostratigraphic ground and in that it gives confusion of nomenclature and definition between time-rock and lithologic units. ANDERson's (1958) other generalized scheme, Pacheco, Lower Asuncion, and Upper Asuncion groups, for the Upper Cretaceous of California similarly gives confusion and is unnecessary, although these names can be used in the original sense of TALIAFERRO (1943). I should recommend use of the international stages as far as possible, unless definite and workable provincial stages can be established. For interregional as well as local correlation an attempt at zonal classification is more important than a hasty proposal of a provincial scheme.

In the present state of knowledge the reference to an international stage is often approximate. We need more evidence to determine clearly the exact boundary of, for instance, the Albian and the Cenomanian in the Californian sequence. The bed with Mortoniceras (Durnovarites) sp. is referable to upper Upper Albian and the bed with Graysonites wooldridgei Young is best assigned to lower Lower Cenomanian. The known localities of the two species in California are isolated (being actually not on a continuously exposed sequence). If YounG's (1958) zonation of the Lower Cenomanian in Texas is warrantable, the bed with $G$. wooldridgei in California does not indicate the basal Cenomanian. We should search for a guide species of the basal Cenomanian below the bed with G. wooldridgei and above the bed with Mortoniceras (Durnovarites) sp., and thus the Albian-Cenomanian boundary would be definitely recognized.

This is an example of a question to be settled in the future. Similarly the exact boundaries of other stages in the Californian sections may be more or less ambiguous, although we may be able to tell their approximate positions. The Campanian-Maestrichtian boundary is more questionable than others, as I have already pointed out (p. 176, 178). The Coniacian-Santonian boundary is questionable too, because of the lack of good guide species in this part of the Californian sequence and because of a doubt about the definition of the Coniacian in the type area of France.

The Cretaceous-Tertiary boundary may be another problem in California as in many other parts of the world. The evidence of ammonites alone does not carry the discussion very far. A concrete example has been given in page 44 [Notes on Stratigraphy-(6) Panoche Hills].

(5) A tentative summary of local correlation.-A chart on Plate 2 summarizes a tentative correlation of the Upper Cretaceous rocks among various local areas in California. The chart concisely indicates the stratigraphy of each area, using symbols to show the main rock constituents of formations or members, and the known stratigraphic positions of representative ammonite localities with black circles. A black circle corresponds to one or more of the guide species and or associated species of the other chart (Plate 1). Relatively well known formational names are indicated. When the formational subdivision is not well established, as in the San Francisco Bay area, only a place name is shown, meaning that a bed with ammonite is known in or near the named place. 
There is much local change in rock-facies within a given area. This is greatly abbreviated in the illustration, but in many cases the local variation is not so well investigated as to be adequately expressed in the figure. For the details of the stratigraphy of each area the reader may refer to the descriptions in the chapter Notes on Stratigraphy, in which discussions about correlation are also given. The number indicated in a large circle corresponds to that in the index map of Introduction (Fig. 1 in Part I) and also to that at the heading of each article in Notes on Stratigraphy.

Ammonites indeed give a workable control for the age determination of formations or members, but they have not been always evaluated for local correlation, because they were found rather sporadically in the Upper Cretaceous of California and because ammonite zonation has not yet been accomplished. In this respect my conclusion is tentative and may be better called a suggestion for local correlation from the standpoint of ammonites. For a reasonable conclusion of correlation we need evidence from various sources. I have taken into consideration to some extent the associated Inoceramus. For this group, however, another paper may be required.

From the view point of molluscan fauna PoPENoE $(1942,1943)$ and then PeCK, Imlay, and Popenoe (1956) attempted faunal division of the Upper Cretaceous in California and gave remarks on correlation between the representative sections. Their results do not greatly contradict mine, but are rather helpful for leading a better conclusion. To take one instance, PopenoE's (1943) conclusion that the upper half of the section at Chico Creek is younger than any of the beds exposed in the Redding area and his suggestion that the lower half of the Chico section may correspond in age to parts of Members IV to VI in the Redding area seem to be confirmed from the evidence of ammonites. There is of course some alteration from the previous to the present results, as the reader may understand from a comparison of the correlation charts. I would not repeat here discussions, which have been given at several points in Notes on Stratigraphy.

Microfossils are certainly useful for correlating Upper Cretaceous beds in California, as was exemplified by GoudKofF (1945). His data, however, hardly tie with mine, except for the type Moreno formation. The correlation between zones of foraminifera and those of ammonites is certainly an important subject. At Professor Schenck's suggestion, Martin, Payne and I attempted this in the Panoche Hills, and the results seem to be promising (personal communication from MARTIN). KÜPPER's (1956) age determination of a part of the "Antelope shale" in Glenn and Colusa counties from the study of pelagic foraminifera is again in harmony with a conclusion from ammonites. In this paper, however, I do not refer much to the results of correlation by micropaleontologists, except in a few reliable cases. I hope that the results of the present study will be of some aid for micropaleontologists too. 


\section{Acknowledgements}

This paper, serially published in Parts I, II, and III, embodies the results of research work during my visit in 1957-58 to the United States under the auspices of the Conference Board of the Associated Research Councils. Financial supports were partly given by Leland Stanford Junior University from the Shell Funds for Fundamental Research and also from the ANDERson Funds through Professor Hubert G. Schenck, by the University of California, and by Kansas University. Without the aids of these grants this study could not have been accomplished.

Thanks are due to Professor Charles F. PARK Jr., Dean of the School of Mineral Sciences, Stanford University, Professor J. Wyatt DuRHAM, Chairman of the Department of Paleontology, University of California (Berkeley), Professor R. A. Stirton, Director of the Museum of Paleontology in the same university, Professor John C. CROWELL, Chairman of the Department of Geology, University of California (Los Angeles), Dr. Robert C. MILLER, Director of the California Academy of Sciences, Professor Raymond C. Moore, Kansas University, Dr. Frank C. FolEY, Director of the State Geological Survey, Kansas, and Dr. G. Arthur CoOPER, Head Curator of the Department of Geology, Smithsonian Institution, United States National Museum, who have rendered me available facilities to work in these institutions; to Dr. W. A. CobBan, Geologic Division, Paleontology and Stratigraphy Branch, United States Geological Survey (Denver), Dr. Horace G. RICKARDS, Associate Curator, Academy of Natural Sciences, Philadelphia, Dr. H. B. Whittington, Curator of Invertebrate Paleontology, Museum of Comparative Zoölogy, Harvard University, Dr. John T. Lonsdale, Director, Bureau of Economic Geology, University of Texas, Dean Claude ALBRITTon, Southern Methodist University, Professor Leo HENDRICKs, Texas Christian University, Mr. M. V. KirK, Paleontology Laboratory, Shell Oil Company (Seattle), Dr. V. Standish Mallory, Department of Geology, University of Washington, Mr. Mackenzie GoRDoN, Jr., Paleontology and Stratigraphy Branch, United States Geological Survey (Menlo Park), and Mr. George F. Sternberg, Curator of the Fort Hays Kansas State College Museum, who generously put at my disposal facilities to work during my shorter visits to these institutions.

I am deeply indebted to Professor Hubert G. Schenck, who took trouble in supervising my work at Stanford and has constantly encouraged me in completing the study, Mr. C. W. WRIGHT, who has given me valuable suggestions from his comprehensive knowledge of Cretaceous ammonites and critically read the first draft of this paper, the late Dr. John B. REEside, Jr., Dr. Ralwph W. Imlay, Dr. William A. CobBan, Dr. David L. JoNes, and Dr. Keith Young who have shown me their precious collections, supplied me with plaster casts for comparative study, and gave me frequent opportunities for fruitful discussions. Dr. CoBBAN and Dr. JoNEs furthermore took me out in the Cretaceous outcrops which I wanted to examine.

Outstanding contributions have been made by Dr. W. Parkison PoPEnoE, 
Mr. Mahlon V. KIRK, Mrs. L. E. Saul, Professor Siemon W. Muller, Dr. Earl L. PACKard, and Mr. Edwin C. Allison, who put at my disposal almost all of their valuable collections of Cretaceous ammonites and Inoceramus and gave me a great deal of necessary information; by Mr. Max B. PAYNE, Stewart CHUBER and again by Dr. W. P. POPENOE, who freely supplied me with up-to-date knowledge of local stratigraphy in California through field work with me and through personal correspondence; by Dr. Leo G. HeRTLEIN of the California Academy of Sciences, Miss A. Myra KeEN of Stanford University, Mr. Joseph H. PECK, Jr., of the University of California (Berkeley), and Mr. Takeo SusukI of the University of California (Los Angeles), who helped me in assembling the scattered material and replying to my countless inquiries about the locality records, and providing me with many plaster casts; and by many other persons whose names are indicated as collectors of ammonites in the list of localities and also in the list of material for the paleontologic descriptions. I sincerely acknowledge all of the above contributions and the present paper should be an evaluation of them.

I appreciate also the kindness of the following who have helped in various ways: Professor Kiyoshi Asano, Dr. Henri Besairie, Professor Roland BrinKmann, Dr. David L. Clark, Mr. Charles W. Cline, General Maurice Collignon, Mr. J. P. Conlin, Dr. A. W. Crompton, Dr. Joseph J. Graham, Dr. G. Dallas Hanna, Dr. Otto HaAs, Dr. M. K. Howarth, Mr. Daniel Jarvis, Dr. Jurij A. Jeletzky, Professor Teiichi Kobayashi, Professor Lewis B. Kellum, Dr. Bernhard Kummel, Mr. J. H. McMaster, Mr. A. W. Merianos, Dr. Lewis Martin, Dr. Halsey W. Miller, Dr. Michael A. MurPhy, Mr. Ikuwo Obata, Professor Ben M. Page, Mr. Peter U. Rodda, Mr. F. A. Shilling, Mr. Parke D. Snavely, Jr., Dr. Jacques SoRnay, Dr. Alexander Stoyanow, Professor Toru Tomita, Professor Ryuzo Toriyama, Mr. John T. Twining, Professor Emeritus Hisakatsu YaBe, and Mr. Saburo Yoshida.

The photographs have been taken at Stanford University by Mr. Alexander Tinonravov $\nmid$, at the University of California (Berkeley) by David H. Massie, at the University of California (Los Angeles) by Takeo Susuki, at the California Academy of Sciences by Charles E. Crompton, at the United States National Museum by Nelson SHUPE, and at Kyushu University by Ikuwo OBATA. Assistance has been rendered by Miss Mitsuye IshikAwA in drawing maps and charts, by Mrs. Mary Anne CoYLE and Miss Chizuko OKAMURA in typewriting manuscripts, by Mr. Yoshihisa OHTA in preparing the index of genera and species, and by Messrs. Ikuwo OBATA and Hakuyu OKADA in proof-reading.

Particular thanks are due to the Ministry of Education of the Japanese Government and the President of Kyushu University for providing funds necessary for the publication of this paper which otherwise would have been impossible.

Finally I appreciate the contribution by Dr. W. P. Popenoe who has taken joint authorship with me for Notes on Stratigraphy of the Redding area and the Santa Ana Mountains. 


\section{Works Cited}

Adkins, W. S., 1928. Handbook of Texas Cretaceous fossils. Univ. Texas Bull., 2838, 303 p., 37 pls., index.

1931. Some Upper Cretaceous ammonites in western Texas. Univ. Texas Bull., 3101, 35-72, pls. 2-5.

1933. The Mesozoic systems in Texas. Univ. Texas Bull., 3232, Part 2, 239-518.

Anderson, F. M., 1902. Cretaceous deposits of the Pacific Coast. Proc. Calif. Acad. Sci., [3], 2, (1), 1-154, pls. 1-12.

- 1931. The genus Fagesia in the Upper Cretaceous of the Pacific Coast. Jour. Paleont., 5, 121-126, pls. 15-17.

, 1938. Lower Cretaceous deposits in California and Oregon. Geol. Soc. Amer., Special Papers, 16, 339 p., 84 pls.

1943. Synopsis of later Mesozoic in California. Calif. Div. Mines, Bull., 118, $183-196$.

1958. Upper Cretaceous of the Pacific Coast. Geol. Soc. Amer., Memoir 71, 378 p., 75 pls.

Anderson, F. M., and Hanna, G. D., 1935. Cretaceous geology of Lower California. Proc. Calif. Acad. Sci., [4], 23, (1), 1-34, pls. 1-11.

Andzrson, Robert and PACK, R. W., 1915. Geology and oil resources of the west border of the San Joaquin Valley north of Coalinga, California. U. S. Geol. Surv. Bull., 603, 1-220.

BaILy, W. H., 1855. Description of some Cretaceous fossils from South Africa; collected by Capt. GARDEN, of the 45th Regiment. Quart. Jour. Geol. Soc. London, 11, 454-465, pls. 11-13.

BARBER, W., 1957. Lower Turonian ammonites from north-eastern Nigeria. Geol. Surv. Nigeria, Bull., 26, 84 p., 34 pls., 3 maps.

BASSE, Éliane, 1931. Monographie paléontologique du Crétacé de la province de Maintirano, Madagascar. Serv. d. Mines, Gouvr. Gen. Madagascar et Dep., 86 p., $13 \mathrm{pls}$.

- 1937. Les céphalopodes crétacés des massifs cotiers Syriens. Haut-Commissaritat de la république française en Syrie et au Liban. Service des Travaux Publics [Sect. d'Études Géologiques], Notes et Mémoires, 2, 165-200, pls. 8-11.

BaYLe, E., 1878. Fossiles principaux des terrains. Explic. Carte géol. France, 4, (1), Atlas, $158 \mathrm{pls}$.

Besairie, Henri, 1936. Recherches géologiques à Madagascar. Première Suite, la géologie du Nord-Ouest. Mem. Acad. Malgache, 21, Texte, 259 p., 3 tables, 1 map; Planches, 24 pls.

Besairie, Henri and Collignon, Maurice, 1956. Le systeme crétacé à Madagascar. Trav. Bureau géol., Madagascar, 77, 66 p.

Billinghurst, S. A., 1927. On some new Ammonoidea from the Chalk Rock. Geol. Mag., 44, 511-518, pl. 16.

BINkhoRst, J. T., 1861. Monographie des gastropodes et des céphalopodes de la craie supérieure du Limbourg. Gastrop. 83 p.; Céph. 44 p., pls. 1-9, Bruxelles.

BlAKE, W. P., 1858. Report of a geological reconnaissance in California: made in connection with the expedition to survey routes in California, to connect with the surveys of routes for railroad from the Mississippi River to the Pacific Ocean, under the command of Lieut. R. S. Williamson, Corps Top. Eng. in 1853.370 p., plates, \& maps.

Bosc, J. A., 1801. Histoire naturelle des Coquilles, etc. 1-5 [1759-1828], Paris.

Boule, M., Lemoine, P. and Thévenin, A., 1906-7. Paléontologie de Madagascar, 
III-Céphalopodes crétacés des environs de Diègo-Suarez. Ann. Paléont., 1, 173-192 [1-20], pls. 14-20 [1-7] (1906) ; 2, 1-56 [21-76], pls. 1-8 [8-15] (1907).

Böнм, J., 1891. Die Kreidebildungen des Fürbergs u. Salzbergs bei Siesdorf in OberBayern. Palaeontographica, 38, 1-106, pls. 1-5.

1927. Beitrag zur Kenntnis der Senonfauna der Bithynischen Halbinsel. Palaeontographica, 69, 187-222, pls. 11-18.

BösE, Emil, 1927 [1928?]. Cretaceous ammonites from Texas and northern Mexico. Univ. Texas Bull., 2748, 143-312, pls. 1-18.

Breistroffer, Maurice, 1936. Les subdivisions du Vraconien dans le Sud-Est de la France. Bull. Soc. géol. France, [5], 6, (1-3), 63-68.

- 1947. Sur les zones d'ammonites dans l'Albian de France et d'Angletere. Trav. Lab. géol., Fac. Sci., Univ. Grenoble, 1946-47, 62, 17-104.

BRIGGS, L. I., Jr., 1953. Geology of the Ortigalita Peak Quadrangle, California. State of Calif., Div. Mines, Bull., 167, 61 p., 4 pls.

BRINkmANN, Roland, 1935. Die Ammoniten der Gosau und der Flysch in den nördlichen Ostalpen. Mitteil. Geol. Staatsinst. Hamburg, 15, 1-14.

Brongniart, A., 1822. In CUVIER and BrongnIART: Description géologique des enirons de Paris. New ed., viii +428 p., 16 pls., 2 maps, Paris.

CASEY, Raymond, 1954. New genera and subgenera of Lower Cretaceous ammonites. Jour. Washington Acad. Sci., 44, 106-115.

Choffat, P., 1898. Recueil d'études paléontol. sur la faune crétacique du Portugal, 1, [2], 41-86, pls. céph. 3-22, Lisbonne.

Clark, S. G., 1940. Geology of the Covelo district, Mendocino County, California. Univ. Calif. Publ., Bull. Dept. Geol. Sci., 25, (2), 119-142.

CobBan, W. A., 1951a. Scaphitoid cephalopods of the Colorado group. U. S. Geol. Surv. Prof. Paper, 239, 42 p., 21 pls.

1951b. New species of Baculites from the Upper Cretaceous of Montana and South Dakota. Jour. Paleont., 25, (6), 817-821, pl. 118.

, 1951c. Colorado shale of central and northwestern Montana and equivalent rocks of Black Hills. Bull. Amer. Assoc. Petrol. Geol., 35, 2170-2198.

1952. A new Upper Cretaceous ammonite genus from Wyoming and Utah. Jour. Paleont., 26, 758-760, pl. 110.

1958a. Two new species of Baculites from the Western Interior Region. Jour. Paleont., 32, (4), 660-665, pls. 90-91.

, 1958b. Late Cretaceous fossil zones of the Powder River Basin, Wyoming and Montana. Wyoming Geol. Assoc. Guidebook, 13th annual field conf.1958, 114-119.

Cobban, W. A. and Reeside, J. B., Jr., 1952. Correlation of the Cretaceous formations of the Western Interior of the United States. Bull. Geol. Soc. Amer., 63, 1011-1044, 1 pl.

Cobban, W. A., Rohrer, W. L., and Erdmann, C. E., 1956. Discovery of the Carlile (Turonian) ammonite Collignoniceras woollgari in northwestern Montana. Jour. Paleont., 30, (5), 1269-1272.

Collignon, Maurice, 1928-29. Les céphalopodes du Cénomanien pyriteux de DiègoSuarez.-Paléont. Madagascar 15. Ann. Paléont., 17, 137-162, pls. 6-19; Ibid. 18, 1-55, pls. 1-7.

1931. Faunes sénoniennes du Nord et de l'Ouest de Madagascar. Ann. géol. Serv. Mines, Madagascar, 1, 1-64, pls. 1-9.

1932. Fossiles du Crétacé supérieur du Ménabe.-Paléontologie de Madagascar, 17. Ann. Paléont., 21, 35-87, pls. 4-12 [1-9].

1936. Fossiles du Turonien supérieur d'Antanitiloky. In Besarrie, Henri: Recherches géologique à Madagascar, Première Suite, La géologie du NordOuest. Mem. l'Acad. Malgache, 21, 200-202, pls. 21. 
1937. Ammonites Cénomaniennes du Sud-ouest de Madagascar. Ann géol. Serv. Mines, Madagascar, 8, 31-72, pls. 1-11.

, 1938. Ammonites Campaniennes et Maëstrichtiennes de l'Ouest et du Sud de Madagascar. Ann. géol. Serv. Mines, Madagascar, 9, 55-115, pls. 1-9.

1939. Fossiles Cénomaniens et Turoniens du Menabe de Madagascar. Ann. géol. Serv. Mines, Madagascar, 10, 1-49, pls. 1-11.

1948a, b. Ammonites néocrétacées du Menabe (Madagascar). I-Les Texanitidae. Ann. géol. Serv. Mines, 13, 49-107 [1-62], pls. 7-20 [1-14]; 14, 7-60 [63-116], pls. 15-32 [15-32], 99-101 [118-120].

1949. Le Crétacé supérieur d'Antonibe. Couches de passage du Crétacé au Tertiaire. Ann. géol. Serv. Mines, Madagascar, 19, 75-148, pls. 13-20 [1-8]. 1955a. Ammonites néocrétacées du Menabe (Madagascar), II.-Les Pachydiscidae. Ann. géol. Serv. Mines, Madagascar, 21, 1-98, pls. 1-28. [Travaux Bureau géol. Madagascar, 41, 114 p., 33 pls., 1952].

1955b. Ammonites néocrétacées du Menabe (Madagascar), III.-Les Kossmaticeratidae. Ann. géol. Serv. Mines, Madagascar, 22, 1-54, pls.1-12. [Travaux Bureau géol. Madagascar, 62, 59 p., 12 pls., 1954].

1956. Ammonites néocrétacées du Menabe (Madagascar), IV.-Les Phylloceratidae; V.-Les Gaudryceratidae; VI.-Les Tetragonitidae. Ann. géol. Serv. Mines, Madagascar, 23, 1-107, pls. 1-11.

Conrad, T. A., 1850-60. Description of new species of Cretaceous and Eocene fossils of Mississippi and Alabama. Jour. Acad. Nat. Sci., Philadelphia, [2], 4, 275-297.

__ , 1865. Observations on certain Eocene fossils described as Cretaceous by Mr. W. M. GABB. Amer. Jour. Conch., 1, 362-365.

1866. Further observations on Mr. GABB's Paleontology of California. Amer. Jour. Conch., 2, 97-100.

CRAGIN, F. W., 1893. A contribution to the invertebrate palaeontology of the Texas Cretaceous. Geol. Surv. Texas, 4th Annual Report [1892], 139-294, pls. 24-46.

CrICK, G. C., 1896. On the aperture of a baculite from the Lower Chalk of Chardstock, Somerset. Proc. Malac. Soc., 2, (2), 77-80.

, 1907. Cretaceous fossils of Natal, 3, Third and Final Report of the Geol. Surv. Natal and Zululand, 161-250, pls. 10-15.

Defrance, M. J. L., 1830. Dictionaire des Sciences naturelles. Conchyliologie, 20, 1-572.

DEKAY, J. E., 1827. Report on several fossil multilocular shells from the State of Delaware. New York Lyceum Nat. Hist. Annals, 2.

Donovan, D. T., 1954. Synoptic supplement to T. Wright's monograph on the Lias ammonites of the British Islands (1878-86). Palaeontogr. Soc. (1953), $54 \mathrm{p}$.

Douvillé, Henri, 1904. Mollusque fossiles. In J. de Morgan: Mission scientif. en Perse. 3, (4), 237-244, 255, Paris.

1912. Evolution et classification des Cératites de la Craie. Bull. Soc. géol. France, [3], 18, (1911), 285-320.

Dujardin, F., 1837. Mémoire sur les couches du sol en Touraine et description des coquilles de la craie et des falaises. Mém. Soc. géol. France, [1], 2, 211-315.

Durham, J. W. and Allison, E. C., 1956. Pacific Coast Cretaceous from Vancouver Island to Baja California. Rúsumé, XX Intern. Geol. Congr., Mexico, 331.

Elias, M. K., 1933. Cephalopods of the Pierre formation of Wallace County, Kansas and adjacent area. Bull. Univ. Kansas, 34, (5), 289-363.

Forbes, Edward, 1846. Report on the Cretaceous fossil invertebrate from southern India, collected by Mr. KAYE and Mr. Cunliffe. Trans. Geol. Soc. London, [2], 7 (1845), 97-174, pls. 7-19.

Fritsch, Anton, 1872. In Fritsch, A. and SchloenbaCh, U.: Cephalopoden der böh- 
mischen Kreideformation, 52 p., 16 pls., Prague.

GABB, W. M., 1864, 1869. Geological Survey of California. Palaeontology, 1, xx+ 243 p., 32 pls., with Preface by J. D. Whitney; Ibid., 2, xiv+299 p., 36 pls.

GARDNER, J. A., 1916. In ClARK, W. B. [Editor] : Maryland Geological Survey, Upper Cretaceous deposits of Maryland, 1022 p., 90 pls., Johns Hopkins Univ. (see Systematic Paleontology, Mollusca)

Geinitz, H. B., 1849. Das Quadersandstein oder Kreidegebirge in Deutschland. 293 p., 12 pls., Freiburg.

, 1872-76. Das Elbthalgebirge in Sachsen. Palaeontographica, 20, I Theil, (8), 277-319, pls. 61-67; II Theil, (5), 161-199, pls. 29-36.

GounkofF, P. P., 1945. Stratigraphic relation of Upper Cretaceous in Great Valley, California. Bull. Amer. Assoc. Petr. Geol., 29, 956-1006.

Greco, B., 1915. Fauna cretacea dell' Egitto. Paleont. Italica, 21, 189-231, pls. 17-22.

GrIEPENKERL, O., 1889. Die Versteinerungen der senonen Kreide von Königslutter im Herzogthum Braunschweig. Palaeont. Abh., 4, (5), 305-419 [1-116], pls. 34-45 [1-12].

Grossouvre, Albert de, 1889. Sur le terrain crétacé dans le Sud-Ouest de basin de Paris. Bull. Soc. géol. France, [3], 17, (1888-89), 475-525, pls. 11-12.

1894, 1901. Recherches sur la Craie supérieure. II. Paléontologie. Les ammonites de la Craie supérieure. Mém. Carte géol. dét. France (1894 [1893]), 264 p., 39 pls.; II. Stratigraphie générale. Ibid. (1901), (1), 1-558, (2), 560-1013.

, 1908. Description des ammonitides du Crétacé supérieur du Limbourg Belge et Hollandais et du Hainaut. Mém. Musée d'Hist. Nat. Belgique, 4, 1-39, pls. $1-11$.

HAAS, Otto, 1946. Intraspecific variation in, and ontogeny of Prionotropis woollgari and Prionocyclus wyomingensis. Bull. Amer. Mus. Nat. Hist., 86, (4), $147-$ 224, pls. 11-24.

Hall, E. B. and Ambrose, A. W., 1916. Descriptions of new species from the Cretaceous and Tertiary of the Tesla, Pleasanton, San Jose, and Mt. Hamilton Quadrangles, California. Nautilus, 30, (6), 68-71; (7), 77-82.

HALL, James and MEEK, F. B., 1856. Descriptions of new species of fossils from the Cretaceous formations of Nebraska, with observations upon Baculites ovatus and $B$. compressus, and the progressive development of the septa in Baculites, Ammonites, and Scaphites. Mem. Amer. Acad. Arts. Sci., [N.S.], 5, 379-411.

Hanna, G. D., 1924. Rectifications of nomenclature. Proc. Calif. Acad. Sci., [4], 13, (10), 151-186.

Hanna, G. D. and Hertlein, L. G., 1943. Characteristic fossils of California. In Jenkins, O. P. [Editor]; Geologic formations and economic development of the oil and gas fields of California, Chap. 6, Paleontology and stratigraphy. State of Calif. Div. Mines, Bull., 118, 165-182.

Hanna, M. A., 1926. Geology of the La Jolla Quadrangle, California. Univ. Calif. Publ., Bull. Dept. Geol. Sci., 16, (7), 187-246, pls. 17-23, 1 map.

HAUER, F. von, 1858. Über die Cephalopoden der Gosauschichten. Beitr. z. Palaeontogr. Österr., 1, (1), 7-14, pls. 1-3.

- 1866. Neue Cephalopoden aus den Gosaugebilden der Alpen. Sitzgsber. Akad. Wiss. Wien, 53, 300-308, pls. 1-2.

HAYASAKA, Ichiro and FUKADA, Atsuo, 1951. On the ontogeny of Barroisiceras minimum YABE from the Upper Ammonite bed in Hokkaido. Jour. Fac. Sci., Hokkaido Univ., [4], 7, 324-330, pls. 1-2.

Hertlein, L. G., 1956. Cretaceous ammonite of Franciscan group, Marin County, California. Bull. Amer. Ass. Petrol. Geol., 40 (8), 1985-2002, 1 pl.

Hertuein, L. G. and Grant, U. S., 1944. The geology and paleontology of the marine 
Pliocene of San Diego, California. Mem. San Diego Soc. Nat. Hist., 2, (1), geol., 37-38.

Hoepen, E. C. N. van, 1920. Description of some Cretaceous ammonites from Pondoland. Ann. Transvaal Museum, 7, (2), 142-147, pls. 24-26.

- 1921. Cretaceous cephalopoda from Pondoland. Ibid., 8, (1), 1-48, pls. 1-11.

HowArTH, M. K., 1958. Upper Jurassic and Cretaceous ammonites faunas of Alexander Land and Graham Land. Falkland Islands Dependencies Survey, Sci. Rep., 21, 16 p., 5 pls.

Huey, A. S., 1948. Geology of the Tesla Quadrangle, California. Calif. State Div. Mines, Bull., 140, 75 p.

Hyat, Alpheus, 1894. Phylogeny of an acquired characteristic. Amer. Philos. Soc. Proc., 32, 349-647, pls. 1-14.

- 1900. Cephalopoda. In ZitTel-Eastman, Textbook of Palaeontology, 1st English ed., 1, 502-604, London.

-._. 1903. Pseudoceratites of the Cretaceous. Edited by T. W. STANToN. Monogr. U. S. Geol. Surv., 44, 351 p., 47 pls.

ImLAY, R. W., 1957. New genera of Early Cretaceous ammonites from California and Oregon. Jour. Wash. Acad. Sci., 47, (8), 275-277.

IMLAY, R. W. and ReESIDE, J. B. Jr., 1954. Correlation of the Cretaceous formations of Greenland and Alaska. Bull. Geol. Soc. Amer., 65, 223-246.

JАCOB, Charles, 1907. Etudes paléontologiques et stratigraphiques sur la partie moyenne des terrains crétacés dans les Alpes françaises. Trav. Lab. géol. Univ. Grenoble, 8, (2), 280-590, pls. 1-6.

1908. Etudes sur quelques ammonites du Crétacé moyen. Mém. Soc. géol. France, Paléont., 15, Mém. 38 (1907), 64 p., 9 pls.

JAHN, J., 1895. Einige Beiträge zur Kenntnis der böhmischen Kreideformation. Jahrb. Geol. Reichsanst., 45, 125-218.

Jiмво, Kotora, 1894. Beiträge zur Kenntniss der Fauna der Kreideformation von Hokkaido. Geol. Palaeont. Abhandl., N. F., 2 [6], (3), 149-194 [1-48], pls. 17-25 [1-9].

Jones, T. S., 1938. Geology of Sierra de la Pena and paleontology of the Indiana formation, Coahuila, Mexico. Bull. Geol. Soc. Amer., 48, 69-150, pls. 1-13.

Jukes-Browne, A. J., 1896. Critical remarks on some of the fossils, in JukES-Browne, A. J. \& HILL, W., 1896: A delimitation of the Cenomanian, being a comparison of the corresponding beds in S. W. England and W. France. Quart. Jour. Geol. Soc. London, 52, 99-178 (especially 142-158), pl. 5.

KaWADA, Michio, 1929. On some new species of ammonites from the Naibuchi district, South Saghalien. Jour. Geol. Soc. Tokyo [Japan], 36, 1-6 (English pages), pl. 14.

Kilian, W. \& Reboul, P., 1909. Des céphalopodes néocrétacés des iles Xeymour et Snow Hill. Wiss. Erg. Swedische Südpolare-Expedition, 1901-3, 3, (6), 1-75, pls. 1-20.

KIRBY, J. M., 1943a. Upper Cretaceous stratigraphy of the west side of Sacramento Valley, south of Willows, Glenn County, California. Bull. Amer. Assoc. Petrol. Geol., 27, (3), 279-305.

KIRBY, J. M., 1943b. In Jenkins, O. P. [Editor]: Geologic formations and economic development of the oil and gas field of California, Chap. 12, Rumsey Hills area (601-606), Sites region (606-608). State of Calif. Div. Mines, Bull., 118, 601-608.

Kitchin, F. L., 1922. Notes on Heteroceras woodsi sp. nov., Appendix I in SherLock, R. L. and NoBle, A. H., Geology of the Country around Beaconsfield. Mem. Geol. Surv., iv $+59 \mathrm{p}$.

Kossmat, Frantz, 1895; 1897; 1898. Untersuchungen über die Südindische Kreide- 
formation, I, II, III. Beitr. Paläont. Geol. Österr.-Ungarns u.d. Orients, 9, 97-203 [1-107], pls. 15-25 [1-11] (1895); 11, 1-46 [108-153], pls. 1-8 [12-19] (1897) ; 11, 89-152 [154-217], pls. 14-19 [20-25] (1898).

KUMMEL, Bernhard, 1954. Status of invertebrate paleontology, 1953, 5, Mollusca: Cephalopoda. Bull. Museum Comparative Zoology, Harvard, 112, (3), 181-192.

KüPPER, Klaus, 1956. Upper Cretaceous pelagic foraminifera from the "Antelope shale", Glenn and Colusa Counties, California. Contr. Cushman Found. Foram. Res., 7, 40-47, pl. 8.

Lamarck, J. B. P. A. de M. de, 1799. Prodrome d'une nouvelle classification des coquilles. Mém. Soc. Hist. Nat., 63-91, Paris.

, 1801. System des animaux sans vertèbres, etc., viii +432 p., Paris.

- 1822. Histoire naturelle des animaux sans vertèbres, etc., 1-7, Paris.

Lasswitz, Rudolf, 1904. Die Kreide-Ammoniten von Texas. Geol. Palaeont. Abhandl., N.F., 6 [10], (4), 223-259, pls. 1-8.

Liebus, Adalbert, 1902. Über einige Fossilien aus der Karpathischen Kreide. Beitr. Paläont. Geol. Oesterr.-Ungarns u.d. Orients, 14, 113-130, pl. 6.

LEONHARDT, R., 1897. Die Fauna der Kreideformation in Oberschlesien. Palaeontographica, 44, 11-70, pIs. 3-6.

Manteld, G., 1822. Fossils of the South Downs, 320 p., 43 pls., London.

MARShALL, P., 1926. The Upper Cretaceous ammonites of New Zealand. Trans. N. Z. Inst., 56, 129-210, pls. 19-47.

Matsumoto, Tatsuro, 1936. Preliminary notes on the so-called Parapachydiscus egertoni (FoRBEs) from Japan. Japan. Jour. Geol. Geogr., 13, (3-4), 259-267, pls. 30-31.

, 1938a. Preliminary notes on some of the more important fossils among the Gosyonoura fauna (Appendix to "The Geology of Gosyonoura Island, Amakusa"). Jour. Geol. Soc. Japan, 45, 13-24, pls. 1-2.

, 1938b. A biostratigraphic study on the Cretaceous deposits of the Naibuchi Valley, South Karahuto. Proc. Imp. Acad. Japan, 14, 190-194.

1938c. Zelandites, a genus of Cretaceous ammonite. Japan. Jour. Geol. Geogr., 15, 137-148, pl.14.

, 1941. A study of the interspecific relations-with special reference to the life period of fossil species. Jour. Geol. Soc. Japan, 48, 17-37 (in Japanese). 1942a. A note on the Japanese Cretaceous ammonites belonging to the subfamily Desmoceratinae. Proc. Imp. Acad. Japan, 18, 24-29.

, 1942b. A note on the Japanese ammonites belonging to the Gaudryceratidae. Ibid., 18, 666-670.

, 1942c. A note on the Japanese ammonoid species belonging to the Tetragonitidae. Ibid., 18, 671-673.

, 1942d. A short note on the Japanese Cretaceous Phylloceratidae. Ibid., 18, 674-676.

1942-43. Fundamentals in the Cretaceous stratigraphy of Japan. Part I. Mem. Fac. Sci., Kyushu Imp. Univ., [D], 1, 129-210, pls. 5-20 (1942) ; Part II \& III. Ibid., 2, 97-237 (1943).

, 1947. A note on the Japanese Pachydiscinae. Rep. Dept., Geol., Fac. Sci., Kyushu Univ., 2, (1), 34-46 (in Japanese).

, 1953. The ontogeny of Metaplacenticeras subtilistriatum (Jімво). Japan. Jour. Geol. Geogr., 23, 139-150, pl. 13.

1954a. Selected Cretaceous leading ammonites in Hokkaido and Saghalien. Appendix in Matsumoto, T. [Editor], 1954. The Cretaceous System in the Japanese Islands, 243-313, pls. 17-36 [1-20].

, 1954b. Family Puzosiidae from Hokkaido and Saghalien. Mem. Fac. Sci., Kyushu Univ. [D], 5, (2), 69-118, pls. 9-23. 
1955a. Evolution of Peroniceratidae. Trans. Proc. Palaeont. Soc. Japan, [N. S.] $18,37-44$.

1955b. Family Kossmaticeratidae from Hokkaido and Saghalien. Japan. Jour. Geol. Geogr., 26, (1-2), 115-164, pls. 8-10.

, 1955c. The bituberculate Pachydiscids from Hokkaido and Saghalien. Mem. Fac. Sci., Kyushu Univ., [D], 5, (3), 153-184, pls. 31-37.

, 1956. Further notes on the Kossmaticeratids from Hokkaido. Japan. Jour. Geol. Geogr., 27, 173-187, pls. 14-16.

1957. A Turonian Damesites from Hokkaido, Japan. Trans. Proc. Palaeont. Soc. Japan, [N. S.], 27, 86-88, pl. 15 .

1959a. Cretaceous ammonites from the Upper Chitina Valley, Alaska. Mem. Fac. Sci., Kyushu Univ., [D], 8, (3), 49-90, pls. 12-29.

, 1959b. Zonation of the Upper Cretaceous in Japan. Mem. Fac. Sci., Kyushu Univ., [D], 9, (2), 55-93, pls. 6-11.

[Editor] (Cretaceous Research Committee) 1954. The Cretaceous System in the Japanese Islands, xiv +324 p., $36 \mathrm{pls}$., Japan Soc. Prom. Sci. Res., Tokyo (for 1953).

Matsumoto, Tatsuro and Miller, H. W., 1958. Cretaceous ammonites from the Spillway excavation of Cedar Bluff dam, Trego County, Kansas. Jour. Paleont., 32, (2), 351-356, pls. 44-45.

Matsumoto, Tatsuro and Obata, Ikuwo, 1955. Some Upper Cretaceous Desmoceratids from Hokkaido and Saghalien. Mem. Fac. Sci., Kyushu Univ., [D], 5, (3), 119-151, pls. 24-30.

Matsumoto, Tatsuro and SaIto, Rinji, 1954. A nearly smooth Pachydiscid from Hokkaido, Japan. Japan. Jour. Geol. Geogr., 24, 87-92, pls. 9-11.

Matsumoto, Tatsuro, Saito, Rinji and Fukada, Atsuo, 1957. Some Acanthoceratids from Hokkaido. Mem. Fac. Sci., Kyushu Univ., [D], 6, (1), 1-45, pls. 1-18.

MEEK, F. B., 1857. Descriptions of new organic remains from the Cretaceous rocks of Vancouver Island. Trans. Albany Inst., 4, (1858-64), 37-49.

1862. Descriptions of new Cretaceous fossils collected by the Northwestern Boundary Commission, on Vancouver and Sucia Islands. Acad. Nat. Sci., Philadelphia, Proc., 13, (1861), 316.

- 1876a. Descriptions and illustrations of fossils from Vancouver and Sucia Islands and other northwestern localities. Bull. U. S. Geol. Geogr., Surv. Terr., 2, (4), 351-374, pls. 2-6.

MeEk, F. B., 1876b. in Meek, F. B. \& HAYden, F. V., 1876. A report on the invertebrate Cretaceous and Tertiary fossils of the Upper Missouri Country. U.S. Geol. Surv. Territ., 9, $8+\mathrm{xix}+629$ p., $45 \mathrm{pls}$.

Michelin, H., 1838. Note sur une argile dépendant du Gault, observée au Gaty, près Gérodôt. Mém. Soc. géol. France, 1, (3), 97-103.

Moffit, F. M., 1938. Geology of the Chitina Valley and adjacent area, Alaska. Bull. U. S. Geol. Surv., 894, 137 p., 16 pls.

Morton, S. G., 1834. Synopsis of the organic remains of the Cretaceous group of the United States, 88 p., 19 pls., Philadelphia.

MooRe, R. C. [Editor] 1957. Treatise on Invertebrate Paleontology, Part L, Mollusca, Cephalopoda, Ammonoidea, L1-L490, Geol. Soc. Amer. \& Univ. Kansas Press.

Moreman, W. L., 1927. Fossil zones of the Eagle Ford of north Texas. Jour. Paleont., 1, 89-101, pls. 13-16.

- 1942. Paleontology of the Eagle Ford group of north and central Texas. Ibid., 16, 192-220, pls. 31-34.

Morrow, A. L., 1935. Cephalopods from the Upper Cretaceous of Kansas. Jour. Paleont., 9, 463-473, pls. 49-53.

Muller, S. W. and Schenck, H. G., 1943. Standard of the Cretaceous System. Amer. 
Ass. Petrol. Geol., 27, (3), 262-278.

MuRPhy, M. A., 1956. Lower Cretaceous stratigraphic units of northern California. Amer. Assoc. Petr. Geol., 40, (9), 2098-2119.

Mutvei, Harry, 1956. A preliminary report on the structure of the siphonal tube and on the precipitation of lime in the shells of fossil Nautiloids. Arkiv Min. Geol., Stockholm, 2, (8), 179-190.

- 1957. On the relations of the principal muscles to the shells in Nautilus and some fossil nautiloids. Ibid., 2, (10), 219-254, 20 pls.

Neumayr, M., 1875. Die Ammoniten der Kreide und die Systematik der Ammonitiden. Zeitschr. deutsch. Geol. Gesell., 27, 854-892.

NeWBERRY, J. S., 1856. Report upon the geology of the route. U. S. War Dept.: Reports on explorations and surveys, to ascertain the most practicable and economic route for a railroad from the Mississippi River to the Pacific Ocean, 6, pt. 2, (1), 1-68.

Nomland, J. O. and Schenck, H. G., 1932. Cretaceous beds at Slate's Hot Springs, California. Univ. Calif. Publ., Bull. Dept. Geol. Sci., 21, (4), 34-49.

NowaK, Jan, 1908-13. Untersuchungen über die Cephalopoden der oberen Kreide in Polen. I. Bull. Acad. Sci. Cracovie, [B], 1908, 327-353, pl. 14; II. Ibid., 1911, 547-589, pls. 32-33; III. Ibid., 1913, 335-415, pls. 40-45.

Orbigny, Alcide d', 1840-42. Paléontologie française. Terrains crétacés 1, Céphalopodes, 662 p., 148 pls. [1-120 (1840) ; 121-430 (1841) ; 431-662 (1842)], Paris.

- 1848. In Dumont-d'Urville: Voyage au Pol Sud et dans l'Oceanie meridionale (Voyage de l'Astrolabe). Géol., pls. 1-6 (Paléont.).

PACKARD, E. L., 1916. Faunal studies in the Cretaceous of the Santa Ana Mountains of southern California. Univ. Calif. Publ., Bull. Dept. Geol. Sci., 9, (12), 137-159, 1 map.

, 1922. New species from the Cretaceous of the Santa Ana Mountains, California. Ibid., 13, (10), 413-462, pls. 24-38.

1956. An Engonoceras from central Oregon. Jour. Paleont., 30, (2), 398-402.

Page, B. M., Marks, J. G., and WALker, G. W., 1951. Stratigraphy and structure of mountains northeast of Santa Barbara, California. Bull. Amer. Ass. Petrol. Geol., 35, (8), 1727-1780.

PASSY, A., 1832. Description géologique de la Seine-Inférieure, 371 p., 20 pls., Rouen. Paulcke, W., 1907. Die Cephalopoden der Obere Kreide Südpatagoniens. Ber. Naturf. Gess. Freiburg i. B., 15, 167-248 [1-82], pls. 10-19 [1-10].

Payne, M. B., 1951. Type Moreno formation and overlying Eocene strata on the west side of the San Joaquin Valley, Fresno and Merced Counties, California. State of Calif., Div. Mines, Special Report, 9, 29 p., 5 pls.

Peck, D. L., Imlay, R. W. and Popenoe, W. P., 1956. Upper Cretaceous rocks of southwestern Oregon and northern California. Bull. Amer. Assoc. Petrol. Geol., 40, (8), 1968-84.

Peron, Alphonse, 1896-97. Les ammonites du crétacé supérieur de l'Algérie. Mém. Soc. géol. France, Paléont., Mém. 17, 88 p., 18 pls. [6 (1896), 1-24, pls. 1-6; 7 (1897), 25-88, pls. 7-18].

Pervinquik̀re, L., 1907. Études de paléontologie tunisienne. 1 Céphalopodes des Terrains sécondaires. Carte géol. Tunise, 428 p., 27 pls. 1910. Sur quelques ammonites du crétacé algerien. Mém. Soc. géol. France, Paléont., 17, Mém. 42, 86 p., 7 pls.

Pickard, Leo, 1929. On Upper Cretaceous (chiefly Maestrichtian) Ammonoidea from Palestine. Ann. Mag. Nat. Hist., [10], 3, 433-456, pls. 9-10.

Pictet, F. J., 1847-53. In PICtet, F. J. and Roux, W. 1847-53. Description des mollusques fossiles qui se trouvent dans les Grès Verts des environs de Genève. Mém. Soc. phys. hist. nat. Genève, 11, (2) (1847), 257-412; 12 
(1849), 157-287; 13, (1) (1853), 73-173, 489-558, pls. 1-51.

Pictet, F. J. and CAmpiche, G., 1858-64. Description des fossiles du terrain crétacé des environs de Ste.-Croix, pts.1-2. Matériaux Paléont. Suisse, [2] (185860), 1-380, pls. 1-43 (pt. 1) ; [3] (1860-64), 381-752, pls. 44-98 (pt. 2), Genève.

Popenoe, W. P., 1937. Upper Cretaceous mollusea from southern California. Jour. Paleont., 11, (5), 379-402, pls. 45-49.

- 1942. Upper Cretaceous formations and faunas of southern California. Bull. Amer. Ass. Petrol. Geol., 26, (2), 162-187.

1943a. Cretaceous formations of the northern Santa Ana Mountains. State Calif., Div. Mines Bull., 118, (3), 364-366.

1943b. Cretaceous: east side Sacramento Valley, Shasta and Butte Counties, California. Bull. Amer. Ass. Petr. Geol., 27, (3), 306-312.

1954. Mesozoic formations and faunas, southern California and northern Baja California. State Calif., Div. Mines, Bull. 170, 15-21.

1957. The Cretaceous gastropod genus Biplica. Its evolution and biostratigraphic significance. Univ. Calif. Pub. Geol. Sci., 30, (6), 425-454, pls. 50-51, 1 chart.

Reagan, A. B., 1924. Cretacic mollusca of Pacific Slope. Pan-Amer. Geol., 41, 179189 , pls. $18-21$.

Redtenbacher, A., 1873. Die Cephalopoden fauna der Gosauschichten in den nördöstlichen Alpen. Abhandl. Geol. Reichsanst., 5, 91-140, pls. 22-30.

ReEside, J. B., Jr., 1923. A new fauna from the Colorado group of southern Montana. U. S. Geol. Surv. Prof. Paper 132-B, 25-46, pls. 11-21.

1927a. Cephalopods from the lower part of the Cody shale of Oregon Basin, Wyoming. Ibid. 150-A, 1-19, pls. 1-7.

1927b. The Scaphites, an Upper Cretaceous ammonite group. Ibid. 150-B 21-36, pls. 9-11.

- 1927c. The cephalopods of the Eagle sandstone and related formations in the Western Interior of the United States. Ibid. 151, 87 p., 45 pls.

Reeside, J. B., Jr. and Weymouth, A. A., 1931. Mollusks from the Aspen shale (Cretaceous) of southwestern Wyoming. Proc. Smithson. Inst. U. S. Nat. Mus., 78, Art. 17, (2860), 1-24, pls. 1-4.

Roman, Fredéric and Mazeran, Pierre, 1913. Monographie paléontologique de la faune du Turonien du Bassin d'Uchaux et de ses dependences. Arch. Musée hist. nat. Lyon, 12, 1-137, pls. 1-11.

Römer [RoEmer], F. A., 1840-41. Die Versteinerungen des Norddeutschen Kreidegebirges. Pt. 1, 1840, 1-48, pls. 1-7; Pt. 2, 1841, 49-145, pls. 8-16, Hannover.

- 1852. Die Kreidebildungen von Texas und ihre organischen Einschlüsse \&c., 100 pp., 11 pls. Bonn.

SaIto, Rinji and Matsumoto, Tatsuro, 1956. A new species of Damesites from the Cenomanian of Hokkaido, Japan. Trans. Proc. Palaeont. Soc. Japan, N. S., 22, 191-194.

SALFELD, H., 1919. Über die Ausgestaltung der Lobenlinie bei Jura- und Kreideammonoideen. Nach. K. Ges. Wiss. Göttingen, Math. Phys. Kl., 3, 449-467.

SAY, Th. G., 1821. Observations on some species of zoophytes, shells, etc., principally fossil. Amer. Jour. Sci., [1], 2, 34-45.

Schenck, H. G. and KeEn, A. Myra, 1940. California fossils for the field geologist, Stanford Univ.

Schenck, H. G. and Muller, S. W., 1941. Stratigraphic terminology. Bull. Geol. Soc. Amer., 52, (9), 1419-26.

Schlocker, J., Bonilla, M. G., and Imlay, R. W., 1954. Ammonite indicates Cretaceous age for part of Franciscan group in San Francisco Bay area, California. Bull. Amer. Assoc. Petrol. Geol., 38, (11), 2372-81, pl.1. 
SCHLÜTER, Clement, 1867. Beitrag zur Kenntnis der jüngsten Ammoneen Norddeutschlands, 36 p., 6 pls., Bonn.

1871-76. Die Cephalopoden der oberen deutschen Kreide. Palaeontographica, 21, 24 (21, 1-24, pls. 1-8, 1871; 25-120, pls. 9-35, 1872; 24, 121-264, pls. 36-55, 1876).

Seunes, J., 1890-91. Contribution à l'étude des céphalopodes du crétacé supérieur de la France. I. Ammonites du calcaire à Baculites du Cotentin. Mém. Soc. Géol. France, Paléontol. [1, (1), 1-7 (1890) ; 2, (3), 9-22 (1891)].

SharPe, Daniel, 1853-57. Description of the fossil remains of mollusca found in the Chalk of England. 1. Cephalopoda. Palaeontogr. Soc. (1853-57), 68 p., 27 pls. [1-26, pls. $1-10,1853$; 27-36, pls. 11-16, 1855; 37-68, pls. 17-27, 1857; Index, $1909]$.

Shimizu, Saburo, 1932. On a new type of Senonian ammonites, Pseudobarroisiceras nagaoi Shimizu, gen. et sp. nov. from Teshio province, Hokkaido. Japan. Jour. Geol. Geogr., 10, 1-4, pl. 1.

- 1934. Ammonites. In Shimizu, Saburo and Obata, Tadahiro: Cephalopoda. Iwanami's series of Geol. \& Palaeont., 137 p., Tokyo (in Japanese).

- 1935a. The Upper Cretaceous ammonites so-called Hamites in Japan. Proc. Imp. Acad. Japan, 17, 271-273.

, 1935b. The Upper Cretaceous cephalopods of Japan, Part I. Jour. Shanghai Sci. Inst. [II], 2, 159-226.

Shumard, B. F., 1854. Paleontology. Description of the species of Carboniferous and Cretaceous fossils collected. In R. B. MARCY: Exploration of the Red River of Louisiana in the year 1852, Wash.

-_. 1861. Description of new Cretaceous fossils from Texas. Trans. Acad. Sci. St. Louis, 1, 590-610.

Sмiтн, J. P., 1898. Development of Lytoceras and Phylloceras. Proc. Calif. Acad. Sci., [3], 1, (4), 129-160, pls. 16-20.

, 1899. The larval stages of Schloenbachia. Jour. Morph., 16, 237-268.

, 1900. The development and phylogeny of Placenticeras. Proc. Calif. Acad. Sci., [3], 1, (7), 180-240.

, 1901. The larval coil of Baculites. Amer. Naturalist, 35, 45.

, 1905. The development of Scaphites. Jour. Geol., 13, 635-654.

Sowerby, J., 1812-23. The Mineral Conchology of Great Britain. 1-4 (pars), pls. 1383 , London.

Sowerby, J. de C., 1823-46. The Mineral Conchology of Great Britain. 4 (pars)-7, pls. 384-648, London.

Spath, L. F., 1921a. On the Upper Cretaceous Ammonoidea from Pondoland. Ann. Durban Museum, 3, 39-57, pls. 6-7.

1921b. On Cretaceous Cephalopoda from Zululand. Ann. South African Museum, 12, (7), 217-321, pls. 19-26.

1922. On the Senonian ammonite fauna of Pondoland. Trans. Roy. Soc. South Africa, 10, (3), 113-147, pls. 5-9.

1923. On the ammonite horizons of the Gault and contiguous deposits. Summ. Progr. Geol. Surv. (1922), 139-149.

, 1923. A monograph of the Ammonoidea of the Gault, vol.1, pt. 1. Palaeontogr. Soc. (1921), 1-72, pls. 1-4.

, 1925a. Senonian Ammonoidea from Jamaica. Geol. Mag., 62, 28-32, pl. 1. , 1925b. On Upper Albian ammonites from Portuguese East Africa, with an Appendix on Upper Cretaceous ammonites from Maputoland. Ann. Transvaal Museum, 11, (3), 179-200, pls. 28-37.

1926. On new ammonites from the English Chalk. Geol. Mag., 63, 77-83. , 1927-33. Revision of the Jurassic cephalopod fauna of Kachh. Mem. Geol. 
Surv. India, Palaeont. Indica, [N.S.], 9, mem. 2, pts. 1-6, 945 p., 130 pls.

1929. Corrections of cephalopod nomenclature. Naturalist, 871, 269-271.

1932. A monograph of the Ammonoidea of the Gault, vol. 2, pt.9. Palaeontogr. Soc. (1930), 379-410, pls. 37-42.

1937. A monograph of the Ammonoidea of the Gault, vol. 2, pt.12. Ibid. (1936), 397-540, pls. 57-58.

, 1940. On Upper Cretaceous (Maestrichtian) Ammonoidea from Western Australia. Jour. Roy. Soc. W. Australia, 26, 41-57, pls. 1-2.

- 1953. The Upper Cretaceous cephalopod fauna of Graham Land. Falkland Isl. Dep. Surv., Sci. Rep., 3, 60 p., 13 pls.

Stanton, T. W., 1893. The fauna of the Shasta- and Chico-formations Bull. Geol. Soc. Amer., 4, 245-256.

- , 1894a. The Colorado formation and its evertebrate fauna. Bull. U. S. Geol. Surv., 106. 288 p., includ. 45 pls., (1893).

- 1894b. The Shasta-Chico series. Bull. Geol. Soc. Amer., 5, 435-464.

- 1896a. Contribution to the Cretaceous paleontology of the Pacific Coast. The fauna of the Knoxville beds. Bull. U. S. Geol. Surv., 133 (1895), 1-132, pls. 1-10.

- 1896b. The faunal relations of the Eocene and Upper Cretaceous on the Pacific Coast. U. S. Geol. Surv. 17th Annual Report, Pt. 1, 1011-1048, 5 pls.

SteinmanN, G., 1895. Die Cephalopoden der Quiriquina Schichten. In SteinmanN, G., DeEcke, W., u. MöRICKE, W.: Das Alter und die Fauna der QuiriquinaSchichten in Chile. Beitr. zur Geol. u. Palaeontol. v. Südamerika, III. Neues Jahrb. f. Min. Beil. Bd., 10, 64-94, pls. 4-6.

STEPHENSON, L. W., 1941. The larger invertebrate fossils of the Navarro group of Texas. Univ. Texas, Bull. 4101, 438 p., 95 pls.

1953. Larger invertebrate fossils of the Woodbine formation (Cenomanian) of Texas, with Decapod crustaceans from the Woodbine formation of Texas by H. B. Stenzel. U.S. Geol. Surv. Prof. Paper 242 (1952), 226 p., 59 pls.

Stewart, R. B., 1927. GabB's California fossil type Gastropods. Acad. Nat. Sci. Philadelphia, Proc. 78 (1926), 287-447, pls. 20-32.

- 1930. GABB's California Cretaceous and Tertiary type Lamellibranchs. Acad. Nat. Sci. Philadelphia, Special Pub., 3, 314 p., 17 pls.

StoliczKa, Ferdinand, 1863-66. Ammonitidae, with revision of the Nautilidae, etc. In Blanford, M. F. \& Stoliczka, F., 1861-1866. The fossil cephalopoda of the Cretaceous rocks of southern India. Mem. Geol. Surv. India, Palaeont. Indica, [3], 216 p., 95 pls. [41-56, pls. 26-31, 1863; 57-106, pls. 32-54, 1864; 107-154, pls. $55-80$, pl. $66 \mathrm{a}, 1865 ; 155-216$, pls. $81-94,1866]$.

TAFF, J. A., 1935. Geology of Mount Diablo and vicinity. Bull. Geol. Soc. Amer., 46, 1079-1100.

TAFF, J. A., Hanna, G. D., \& Cross, C. M., 1940. Type locality of the Cretaceous Chico formation. Bull. Geol. Soc. Amer., 51, 1311-1327.

TALIAferRo, N. L., 1943. Geologic history and structure of the central coast range of California. State Calif. Div. Mines Bull. 118, 119-162, 2 pls.

, 1944. Cretaceous and Paleocene of Santa Lucia Range, California. Bull. Amer. Assoc. Petrol. Geol., 28, (4), 449-521.

Tokunaga, Shigeyasu and Shimizu, Saburo, 1929. The Cretaceous formation of Futaba in Iwaki and its fossils. Jour. Fac. Sci., Imp. Univ. Tokyo, [2], 1,(6), 181-212, pls. 26-27.

TraSk, J. B., 1856. Description of a new species of ammonite and baculite from the Tertiary rocks of Chico Creek, California. Proc. Calif. Acad. Nat. Sci., 1, $52-93$, pl. 1.

UhLIG, V., 1907. Die Cephalopodenfauna der Wernsdorfer Schichten. Denkschr. $K$. 
Akad. Wiss., Wien, Math.-Nat. Kl., 46, 127-290, pls. 1-32.

UsHer, J. L., 1952. Ammonite faunas of the Upper Cretaceous rocks of Vancouver Island, British Columbia. Geol. Surv. Canada, Bull. 21, 182 p., 31 pls.

Venzo, Sergio, 1936. Cefalopodi del Cretaceo medio-superiore dello Zululand. Pal. Italica, 36, 59-133, pls. 5-12.

WARING, C. A., 1917. Stratigraphic and faunal relations of the Martinez to the Chico and Tejon of southern California. Proc. Calif. Acad. Sci., [4], 1, 41-124, pls. 7-16.

WeAver, C. E., 1949. Coast ranges north of San Francisco Bay. Geol. Soc. Amer., Memoir 35, 242 p., 8 maps.

Whedkind, R., 1916. Zur Systematik der Ammonoidea. Centralbl. Min. Geol. u. Paläont. 17, 529-538.

Weller, Stuart, 1907. A report of the Cretaceous paleontology of New Jersey based upon the stratigraphic studies of George N. KNAPP. Geol. Surv. New Jersey, Paleont. ser., 4, 1106 p., 91 pls.

White, C. A., 1883. Contributions to invertebrate paleontology. No. 2. Cretaceous fossils of the western states and territories. U. S. Geol. Geogr. Surv. Terr. Ann. Rep. 12, (1), 5-39, pls. 11-18.

1885a. Notes on the Mesozoic and Cenozoic paleontology of California. Bull. U. S. Geol. Surv., 15, 7-33.

, 1885b. On new Cretaceous fossils from California. Ibid., 22, 353-373, pls. 1-5. 1889. On invertebrate fossils from the Pacific coast. Ibid., 51, 1-70, pls. 1-14.

Whiteaves, J. F., 1876. On some invertebrates from the coal-bearing rocks of the Queen Charlotte Islands. Geol. Surv. Canada, Mesozoic Fossils, 1, (1), 1-92, pls. 1-10.

1879. On the fossils of the Cretaceous rocks of Vancouver and adjacent islands in the Strait of Georgia. Ibid., 1, (2), 93-190, pls. 11-20.

, 1884. On the fossils of the coal-bearing deposits of the Queen Charlotte Islands collected by Dr. G. M. DAwson in 1878. Ibid., 1, (3), 191-262, pls. 21-32.

, 1900. On some additional or imperfectly understood fossils from the Cretaceous rocks of Queen Charlotte Islands, with a revised list of the species from these rocks. Ibid., 1, (4), 263-307, pls. 33-39.

, 1903. On some additional fossils from the Vancouver Cretaceous, with a revised list of species therefrom. Ibid., 1, (5), 309-409, pls. 40-51.

1895. On some fossils from the Nanaimo group of the Vancouver Cretaceous. Trans. Roy. Soc. Canada, [2], 1, (4), 119-133.

Whitney, J. D., 1865. Report of progress and synopsis of the field work, from 1860 to 1864. Geol. Survey Calif., Geol., 1, xxvii+498 p., 8 pls.

Woods, Henri, 1896. The mollusca of the Chalk Rock, Part I. Quart. Jour. Geol. Soc. London, 52, 69-98, pls. 2-4.

1906. The Cretaceous fauna of Pondoland. Ann. S. African Museum, 4, (7), (12), 275-350, pls. 33-44.

Wright, C. W., 1952. A classification of the Cretaceous ammonites. Jour. Paleont., 26, (2), 213-222.

1953. Notes on Cretaceous ammonites.-I. Scaphitidae. Ann. Mag. Nat. Hist., [12], 6, 473-376.

, 1955. Notes on Cretaceous ammonites.-II. The phylogeny of the Desmocerataceae and the Hoplitaceae. Ibid., [12], 8, 561-573.

1957. Proposed use of the plenary powers to suppress the generic name "Kotoceras" YABE, 1927, for the purpose of validating the names "Kotoceras" Kobayashi, 1934 (Class Cephalopoda, Order Nautiloidea) and "Damesites" Matsumoto, 1942 (Class Cephalopoda, Order Ammonoidea). Bull. Zool. Nomencl., 13, (7), 225-227. 
- 1957. In Moore, R. C. [Editor]: Treatise on Invertebrate Paleontology, Part L, Mollusca, Cephalopoda, Ammonoidea, L1-L490, Geol. Soc. Amer. \& Univ. Kansas Press.

Wright, C. W. and Matsumoto, Tatsuro, 1954. Some doubtful Cretaceous ammonite genera from Japan and Saghalien. Mem. Fac. Sci., Kyushu Univ., [D], 4, (2), 107-134, pls. 7-8.

Wright, C. W. and Wright, E. V., 1951. A survey of the fossil Cephalopoda of the Chalk of Great Britain. Primarily a nomenclatorial revision of Daniel SHARPE's "Description of the fossil remains of mollusca found in the Chalk of England, Part I. Cephalopoda" (1853-1857). Paloeontogr. Soc. (1950), 40 p.

YABE, Hisakatsu, 1901-2. Note on three Upper Cretaceous ammonites from Japan, outside of Hokkaido. Jour. Geol. Soc. Tokyo, 8 (1901), 1-4 (Engl. p.); 9 (1902), 5-10 (Engl. p.), pl. 10.

— , 1903-4. Cretaceous Cephalopoda from Hokkaido. Part I. Jour. Coll. Sci., Imp. Univ. Tokyo, 18, (2), 1-55, pls. 1-7 (1903) ; Part II. Ibid., 20 (2), 1-45, pls. 1-6 (1904).

- 1910. Die Scaphiten aus der Oberkreide von Hokkaido. Beitr. Paläont. Geol. Österr.-Ungarns u.d. Orients, 23, 159-174, pl. 15.

1927. Cretaceous stratigraphy of the Japanese Islands. Sci. Rep. Tohoku Imp. Univ., [2], 11, 27-100, pls. 3-9.

YABE, Hisakatsu and SHimizu, Saburo, 1921. Notes on some Cretaceous ammonites from Japan and California. Ibid., [2], 5, 53-59, pls. 8-9.

YABE, Hisakatsu and Shimizu, Saburo, 1925. Japanese Cretaceous ammonites belonging to Prionotropidae, I. Ibid., [2], 7, (4), 125-138, [1-4], pls. 30-33.

YABE, Hisakatsu and Shimizu, Saburo, 1926. A study on the genus "Parapachydiscus" Hyatт. Proc. Imp. Acad. Japan, 2, 171-173.

Young, Keith, 1957. Cretaceous ammonites from eastern Apache County, Arizona. Jour. Paleont., 31, (6), 1167-1174, pls. 149-150.

- 1958. Graysonites, a Cretaceous ammonite in Texas. Ibid., 32, (1), 171-182, pls. 27-29.

Yoкоуама, Matajiro, 1890. Versteinerung aus der japanische Kreide. Palaeontographica, 36, 159-202, pls. 18-25.

ZitTel, K. A., 1884. Handbuch der Palaeontologie. 1, Abt. 1, Lief. 3, Cephalopoda, 329-522. Munich and Leipzig.

1895. Grundzüge der Palaeontologie, (Palaeozoologie). viii +972 p., Munich and Leipzig.

Addenda:

Durham, J. W. and KIrk, M. V., 1950. Age of the Coralliochama beds of the Pacific Coast (abstract). Bull. Geol. Soc. Amer., 61, (12), 1537.

Stewart, Ralph, 1946. Geology of Reef Ridge, Coalinga district, California. U.S. Geol. Surv. Prof. Paper 205-c, 81-115, pls 11-17, map. 


\section{Index of Genera and Species}

The following index includes names of species and genera described or discussed in Part I (indicated as I/ in the index) and Part II (II/) of this paper. Plates are indicated by boldface type followed by a number of a figure (as 25, 2=Pl. 25, fig. 2).

Acanthoceras, II/81

Acanthoceras sp., II/84; 25, 2

acutus, Turrilites, II/156

ainuanus, Damesites, II/12

alamedense, Lytoceras, II/145

amphibolum, Acanthoceras, II/86

Anagaudryceras, II/138

Anapachydiscus, II/38

Anapuzosia, II/21

Anazelandites, II $/ 148$

anceps, Baculites, I/129, 130

anceps, Baculites aff., I/130;34, 3; 35,

$1 ; 142$

anceps var. leopoliensis, Baculites, I/134

angusteumbilicatum, Submortoniceras,

II $/ 131$

angustum, Hauericeras (Gardenieras), II $/ 24 ; 4,4$

arbucklensis, Patagiosites, II/60; 16, 1 ;

17, 1, 2

arenaica, Puzosia (Parapuzosia), II/62

arrialoorensis, Anapachydiscus, II/38

ashlandicum, Tragodesmoceras, II/26; 5,

1

asper, Baculites, I/124

asperiformis, Baculites, I/124

asperoanceps, Baculites, I/121

aureum, Lytoceras (Gaudryceras), II/ 139, 141

auspicium, Calycoceras (Metacalycoce-

ras), II $/ 80,108$

Austiniceras, II/28

Australiella, II/125

averill, Tragodesmoceras, II/29

awajiense, Didymoceras, II/157

Baculites, I/100, 111

baculoide, Sciponoceras, I/104, 31, 1; 107

bailyi, Baculites, I/135, 149

bakeri, Schloenbachia, II/107

Barroisiceras, II/121

barryae, Desmoceras (Pseudouhligella), II $/ 7$

bassi, Tragodesmoceras, II/28

beantalyense, Lewesiceras, II/32

beantalyensis, Tetragonites, II/152

Bererella, II/125 bergeri, Mariella, II/156

besairiei, Baculites, I/117; 120, 124, 163

bidwelli, Parapachydiscus, II/42, 51

birkhauseri, Lytoceras (Gaudryceras), II $/ 146,147$

bizeti, Acanthoceras, II/89

bohemicum, Sciponoceras, I/110

bohemicum, Sciponoceras aff., 1/109; 30, 2, $3 ; 31,4$

Bostrychoceras, II/158

boulei, Baculites, I/118; 32, 7; 33, 4-7; 124

boulei, Calycoceras, II/75; 20, 1

boulei, Pseudoschloembachia, II/134

boulei, Pseudoschloenbachia aff., II/133;

35, $3 ; 36,2$

brannani, Pseudoschloenbachia, II/134

branneri, Subprionocyclus, II/109

brevicosta, Baculites, I/117, 121, 128

buckhami, Pachydiscus, II/47; 10, 1; 11,

1,$2 ; 17,3$

budaense, Mantelliceras, II/71

buttense, Bostrychoceras, II/158

buttense, Butticeras, II/132

buttense, Schloenbachia, II/131

Butticeras, II/132

Calycoceras, II/72, 94

californicum, Metaplacenticeras, II/135

californicum, Plesiovascoceras, II/102;

36, 1

californicus, Anapachydiscus, II/39

californicum, Prionocycloceras, II/122

Canadoceras, II/52

cantianum, Mantelliceras, II/71

capensis, Baculites, I/121; 33, 1-3; 45,

$1-4 ; 149$

catarinae, Parapachydiscus, II/155*

catarinae, Pachydiscus (Neodesmoceras),

II $/ 40,41$

celeste, Canadoceras, II $/ 54$

ceratopse, Hyphantoceras, II/158

chicoense, Submortoniceras, II/126; 32,

1; 33, 1; 34, 1-3; 35, 1, 2

chicoensis, Baculites, I/145; 36, 2; 37, 1; 154

Cirroceras, II/157 
claviformis, Baculites, I/159

clypeale, Tragodesmoceras, II/28

clypeloide, Tragodesmoceras, II $/ 27$

coalingense, Lytoceras (Gaudryceras),

II $139,141,146,147$

coalingensis, Parapachydiscus, II/42, 44

colligatus, Pachydiscus, II/38, 41

Collignoniceras, II/104, 109

columna, Baculites, I/161 30, 1; 34, 4; 43, $4 ; 165$

colusaense, Pachydesmoceras, II/22

communis, Lechites, II/170

compressum, Patagiosites, II/60, 63

compressus, Baculites, I/139, 141

condoni, Scaphites, II/171

condoni var. appressus, Scaphites, II/171

cornigerum, Acanthoceras, II/86

crenulatum, Prionocycloceras, II/122

cristatus, Prionotropis, II/111

cumminsi, Romaniceras, II/91

cumshewaensis, Marshallites, II/64

Cyrtochilus, I/103

damesi, Damesites, II/12

damesi intermedius, Damesites, II/12

Damesites, II/11

dawsoni, Desmoceras (Pseudouhligella), II/6, 11

declive, Bostrychoceras, II/159

Delawarella, II/125

delawarense, Submortoniceras (Delawarella), II/126

denmanense, Gaudryceras (s.s.) cf., II/

144; 37, 2

delvallense, Lytoceras (Gaudryceras), II $/ 143$

denseplicatum denseplicatum, Gaudryceras, II/143

denseplicatum, Gaudryceras (s.s.), II/ 142

denseplicatum intermedium, Gaudryceras, II/143

densicostata, Mesopuzosia cf., II/18

dentonense, Eucalycoceras, II/97

Desmoceras, II/6

Desmophyllites, II/8

deverioide, Romaniceras, II/87; 25, 1;

26,$1 ; 28,1 ; 29,4$

deverioides var. inermis, Ammonites, II/ 89

diabloense, Calycoceras (Eucalycoceras), II $/ 74$

diabloensis, Parapachydiscus, II/45

Didymoceras, II/157 diphylloides, Desmophyllites, II/9; 3, 3

Diplomoceras, II/165

dissimilis, Baculites, I/131

dobbinsi, Nowakites, II/62

egertoni, Pachydiscus, II/43

egertoni, Pachydiscus (s.s.) cf., II/42

ellipticus, Scalarites, II/166

elkhornensis, Pachydiscus, II/48, 49

elongatum, Bostrychoceras, II/159

embergeri, Tetragonites, II/152

Eocanadoceras, II/21

Eogunnarites, II/64

Epigaudryceras, II/141

Epigoniceras, II/149

Euasteroceras, II/83

Eubaculites, I/100, 154, 165

Eucalycoceras, II/94

Euhomaloceras, I/100

Euomphaloceras, II/101

Eupachydiscus, II/30

evolutum, Acanthoceras, II/86

excelsus, Turrilites, II/157

Exicrioceras, II/157

Exiteloceras, II/157, 162

fairbanksi, Baculites, I/111, 135, 162

fascicostatus, Anapachydiscus, II/40

fascicostatus, Joaquinites, II/46, 47

florencae, Sharpeiceras, II/71

fraternus, Ammonites, II/54

frazierense, Kotôceras, II/12, 13

fuchsi, Baculites, I/134

gabbi, Parapachydiscus, II/50

gabbi, Parapachydiscus aff., II/48

ganesa, Ammonites, II/45

Gardeniceras, II/24

gardeni, Hauericeras (Gardeniceras), II $/ 25$

gaudini, Lechites, I/101, 162

gaudini, Lechites aff., I/101;30, 4

gaudini var. raricostatus, Lechites, I/102

Gaudryceras, II/141, 142

georgianum, Canadoceras, II/54

gillisi, Scaphites, II/171

rlabrus problematicus, Tetragonites, II/

151

glabrus, Tetragonites, II/149; 39, 2, 3

Glyptoxoceras, II/165, 166

gorrilli, Puzosia (Holcodiscoides), II/62

gothicum, Eucalycoceras, II/94

gracile, Sciponoceras, I/106, 107

grandis, Baculites, I/141, 159

graysonensis, Ammonites, II/106

Graysonites, II/65 
gregoriensis, Baculites, I/141

hannai, Puzosia (Eocanadoceras), II/21

haradai, Eupachydiscus, II/33

haradai haradai, Eupachydiscus, II/34

haradai usheri, Eupachydiscus, II/34

Hauericeras, II/24

hearni, Puzosia (Parapuzosia), II/20

Hemigaudryceras, II/141

henleyense, Lytoceras (Tetragonites), II $/ 149,153$

henleyensis, Anapachydiscus, II/39

Heteroceras, II/167

hetonaiense, Neophylloceras, II/5; 3, 1

hetonaiensis, Damesites, II/12, 15

hetonaiensis fresnoensis, Damesites, II/

14,15

hetonaiensis hetonaiensis, Damesites, II/ 15

hippocrepis, Scaphites, II/172

hitchinensis, Subprionocyclus, II/117

- hochstetteri, Baculites, I/134, 141

hoepeni, Canadoceras, II/53

hoepeni, Canadoceras aff., II/63

Hoepenites, II/63

hornbyense, Didymoceras, II/157

Hulenites, II/64

hyatti, Collignoniceras, II/106

Hyphantoceras, II/158, 162

Hyporbulites, II/1

Hypogaudryceras, II/148

imlayi, Submortoniceras, II/131

incurvatus, Euhomaloceras, I/125

indianense, Eucalycoceras, II/98

indicum, Bostrychoceras, II/159

indicum, Glyptoxoceras, II/167;41, 2-6

indicum, Sharpeiceras, II/69

indiduraense, Romaniceras, II/98

indopacifica, Mesopuzosia, II/18, 19

indra, Pseudophyllites cf., II/154

inermis, Scaphites, II/172

inflatus, Zelandites cf., II/148

inornatus, Baculites, I/155; 38, 1; 43, 5; 165

intermedia, Puzosia, II/16

intermedia intermedia, Puzosia, II/16, 17

intermedia kossmati, Puzosia, II/16, 17

intermedia orientalis, Puzosia, II/16;4, 1

isculensis, Eupachydiscus, II/33

jacksonense, Lytoceras (Tetragonites),

II $/ 150,151$

jacquoti, Pachydiscus, II/42, 44

japonicum, Bostrychoceras, II/159

japonicum, Desmoceras (Pseudouhligel- la), II $/ 6$

japonicum, Kossmaticeras aff., II/64

jillsoni, Oregoniceras, II/117

jimboi, Hulenites, II/64

Jimboiceras, II/20

Joaquinites, II/41

kaiparaensis, Zelandites, II/148

Kanabiceras, II/98

kawanoi, Zelandites, II/148

kawasakii, Texanites cf., II/124; 28, 2

kayei, Gaudryceras (Vertebrites), II/146

kernense, Lytoceras (Tetragonites), II/

152, 153

kirki, Baculites, I/143; 43, 1-3

klamathensis, Fagesia, II/35

klamathensis, Scaphites, II/172

klamathonae, Puzosia (Parapuzosia), II/18

klamathonis, Nowakites, II/64

knighteni, Schloenbachia, II/113, 116

koluturensis, Anapachydiscus, II/39

kossmati, Canadoceras, II/55, 58

kossmati, Desmoceras, II/7; 2, 2

kossmati, Sciponoceras, I/106; 31, 2, 3; 149

Kossmatia, II $/ 86$

Kossmaticeras, II/64

Kotoceras, II/12

lambertense, Neophylloceras, II/4, 5

lamberti, Eupachydiscus, II/31

lamberti, Eupachydiscus aff., II/30

largesulcatum, Glyptoxoceras (?), II/169

laticarinatus, Damesites, II/12

laticlavium, Sharpeiceras, II/69

laticlavium var. mexicanum, Sharpeiceras, II/69

latidorsatum, Desmoceras, II/8

Latidorsella, II/6

laqueum, Hyphantoceras, II/158

Lechites, I/99, 101; II/170

levyi, Eupachydiscus, II/30

lineatum, Ancyloceras, II/161

lineatum, Pseudoxybeloceras, II/162;40, $1 ; 41,1$

loboense, Romaniceras, II/89

lomaensis, Baculites, I/126; 34, 1, 2

lonsdalei, Euomphaloceras, II/102

Lunatodorsella, II/6

Maccarthyites, II/64

major, Cyrtochilus, I/106

Mantelliceras, II/66, 71, 72

Mariella (s.s.), II/156

Mariella (Plesioturrilites) sp., II/156 
Marshallites, II/ 64

Menabites, II/125

Mesopachydiscus, II $/ 30$

Mesopuzosia, II/17, 28

Metaplacenticeras, II/135

mexicanum, Collignoniceras (Selwynoceras), II/106

mexicanum, Solenoceras, II/158

mickeyi, Hauericeras, II/24, 25

mihoensis, Scalarites, II/170

mihoensis, Scalarites cf., II/165; 37, 3

Mikasaites, II/64

mikobokense, Anagaudryceras, II/139;

38, 1

miliaris, Mariella, II/156

minimus, Reesidites, II/121

mite, Gaudryceras, II/141

moultoni, Plesiovascoceras II/104

moreti, Lechites, I/102

multicostatum, Canadoceras, II/57

multisulcatum, Canadoceras, II/58

mysticum, Canadoceras, II/59;15, 2, 3; 62

nagaoi, Pseudobarroisiceras, II/135

naviculare, Calycoceras, II/78, 81

neevesi, Pachydiscus, II $/ 51$

Neocardioceras, II/101

Neocrioceras, II/162

Neodesmoceras, II/41

Neogaudryceras, II/141

Neokotôceras, II/15

Neopachydiscus, II $/ 63$

Neophylloceras, II/1

Neopulchellia, II/69

neputuni, Subprionocyclus, II/111, 112;

29, 2, 3; 30, 1, 2; 121

neubergicus, Pachydiscus, II/43

newberryanum, Canadoceras, II/53; 14,

$2 ; 58$

newboldi, Calycoceras, II/78

normalis, Subprionocyclus, II/118; 29, 1;

31, 1-5

notabile, Diplomoceras, II/165

Nowakites, II/57

obrieni, Calycoceras, II/81

obstrictum, Polyptychoceras, II/165, 170

obtectum, Forbesiceras cf., II/156

occidentalis, Baculites, I/150; 35, 2, 3;

36,$1 ; 41,1,2 ; 159,170$

olcostephanoides, Marshallites, II/64

onoense, Hypophylloceras, II/4

ootacodensis, Eubaculites, I/166;43, 6;

44, 1-3 ootacodensis, Pachydiscus, II/41, 51 oregonense, Mantelliceras, II/79

oregonensis, Pachydiscus, II/26, 28

oregonensis, Schloenbachia, II/109, 121

oregonensis, Turrilites, II/156

Oregoniceras, II/108

orestimbense, Didymoceras, II/158

orientale, Calycoceras cf., II/73; 19, 1

oshimai, Hyphantoceras, II/158

Otoscaphites, II/172

otsukai, Bostrychoceras, II/161

otsukai, Bostrychoceras aff., II/160; 40, 2

otsukai var. multicostata, Bostrychoceras, II/161

Oxybeloceras, II/162

pachecoense, Phylloceras, II/2, 3

pachecoensis, Parapachydiscus, II/48

pachecoensis, Turrilites, II/156

Pachydesmoceras, II/22

pachydiscoide, Pachydesmoceras, II/22

Pachydiscus, II/41

pachystoma, Kossmaticeras, II/65

pacifica, Mesopuzosia, II/18; 6, 2

pacificum, Metaplacenticeras, II/135

palestinensis, Baculites, I/160

panochensis, Parapachydiscus, II/51

Parapachydiscus, II/41

Patagiosites, II/60

patagiosus, Patagiosites, II/63

peninsularis, Anapachydiscus, II/38

pentagonum, Eucalycoceras, II/97

pentzanum, Mortoniceras (Submortoniceras ), II/129

pepperense, Acanthoceras, II/86

peregrinus, Pseudophyllites, II/155

perplicatus, Pachydiscus, II/35

perrini, Otoscaphites, II/172

petersoni, Pseudohelicoceras, II/156

petrolense, Pseudoxybeloceras, II/162

phoenixense, Eucalycoceras, II/94

phoenixense, Oregoniceras, II/121

pittensis, Scaphites, II/171

piveteaui, Submortoniceras, II/130

Placenticeras, II/135

planulatiforme, Jimboiceras cf., II/21

planus, Scaphites, II/171

Plesiovascoceras, II $/ 102$

politissimum, Anagaudryceras, II/139, 141

polyplocum, Bostrychoceras, II/159

Polyptychoceras, II/165

popetensis, Tetragonites, II/151, 152 
poronaicum, Desmoceras (Pseudouhligella), II $/ 7$

Prionocyclus, II/109

Prionotropis, II/104

Protexanites, II/125

pseudoaequalis, Scaphites, II/171

Pseudobaculites, I/100

pseudodeverianum, Romaniceras aff., II/

92; 27, 1

Pseudogaudryceras, II/141

pseudogaultinum, Polyptychoceras, II/38, 165

Pseudohelicoceras, II/156

Pseudopuzosia, II/63

Pseudophyllites, II/154

Pseudoschloenbachia, II/132

Pseudouhligella, II/6, 28

Pseudoxybeloceras, II/157, 161

puerculus, Otoscaphites, II/172

punicum, Bostrychoceras, II/159

Puzosia, II/16

quadrinodosum, Pseudoxybeloceras, II/ 162,163

quintoense, Peroniceras, II/123

ramosum, Neophylloceras, II/1; 1, 1; 2 , $2 ; 8,1$

randalli, Mortoniceras (Submortonice. ras), II $/ 129$

raricostatus, Lechites, I/162

rectus, Baculites, I/149

reesidei, Hulenites, II/ 64

reesidei, Solenoceras, II/158

Reesidites, II/109, 121

reussianum, Hyphantoceras, II/158

rex, Baculites, I/136; 31, 5; 34, 5; 39, $1-3 ; 40,1$

rhotomagense, Acanthoceras, II/82, 83

richardsoni, Kotôceras, II/12, 13

roguensis, Scaphites, II/171

Romaniceras, II/86

rosewoodensis, Pachydiscus, II/22

rousseauxi, Peroniceras, II/123

rugatum, Glyptoxoceras, II/169

rumseyensis, Nowakites, II/62

Ryugasella, II/169

ryugasensis, Ryugasella, II/169; 37, 4

sacya, Anagaudryceras, II/138

Saghalinites, II/142, 149

sanctaemonicae, Metaplacenticeras, II/ 135

sanushibense, Neocrioceras (?), II/162, 164

Scalarites, II/165
Scaphites, II/171

schencki, Baculites, I/113; 32, 1-6; 124

scheuchzerianus, Turrilites (Euturrilites) cf., II/156

Schlüteria, II/8

Sciponoceras, I/99, 103

selwynianus, Desmophyllites, II/9

semicostatus, Damesites, II/12, 15

septemseriatum, Kanabiceras, II/99; 24,

1

seresitense, Neophylloceras, II/1

serpiens, Bostrychoceras, II/159

Sharpeiceras, II/66

shastense, Eucalycoceras (?), II/94; 23, $1 ; 24,2,3$

shastense, Peroniceras, II/123

shastensis, Fagesia, II/103

sherborni, Acanthoceras, II/86

simplex, Eubaculites (?), 1/145

simplex, Pachydiscus II/63

siskiyouensis, Anapachydiscus (?), II/39

siskiyouensis, Desmophyllites, II/10

siskiyouensis, Schloenbachia, II/113

Solenoceras, II/157, 158, 162

spathi, Submortoniceras, II/131

spinigerum, Neocrioceras, II/164

spinosum, Calycoceras cf., II/72; 21, 2

splendidum, Nostoceras, II/158

stanislausense, Lyelliceras, II/99

stanislausensis, Parapachydiscus, II/42

stantoni, Plesiovascoceras, II/104

stoliczkai, Calycoceras, II/77, 78; 21, 1 striatum, Gaudryceras, II/142

studleyi, Butticeras, II/132

stylus, Cyrtochilus, I/106

subcompressum, Glyptoxoceras, II/169

subcompressus, Pachydiscus (s.s.) cf., II $/ 46$

subcompressus obsoletus, Pachydiscus, $\mathrm{II} / 46$

subcompressus subcompressus, Pachydiscus, II/46

Submantelliceras, II/71

Submortoniceras, II/125

Subprionocyclus, II/108

subtililobatus, Anapachydiscus, II/51

subtilistriatum, Metaplacenticeras, II/ 135

subtricarinatum, Peroniceras, II/123

suciaensis, Pachydiscus, II/36, 44

sugata, Damesites, II/12

taffi, Oxybeloceras, II/164

tchihatcheffi, Pseudokossmaticeras cf., 
II $/ 65$

tehamense, Peroniceras, II/123

templetoni, Schloenbachia, II/130

tenuiliratum, Gaudryceras, II/138, 141, 143,145

tenuisulcatum, Diplomoceras, II/165*, 168

teres, Baculites, I/163

teres, Baculites (?) aff., I/163; 45, 5, 6 teshioensis, Eupachydiscus, II/31

teshioensis, Eupachydiscus sp. aff., II/31, 6, 1

teshioensis, Prionotropis, II/107

Tetragonites, II/149

Tetragonites (s.s.), II/142, 149

Texanites, II/124

thomi, Plesiovascoceras, II/104

tongoboryense, Lewesiceras, II/32

Tragodesmoceras, II/25

Tragodesmoceroides, II/28

transitionale, Hauericeras, II/25

turneri, Ammonites, II/83

uchauxiense, Romaniceras, II/93

umbulazi, Pseudoschloenbachia, II/134

umtafunensis, Parapachydiscus, II/63

undatus, Baculites, I/159

vaculae, Phylloceras, II/2, 3

vagina, Eubaculites, I/129, 170

vancouverense, Hoplitoplacenticeras, II/

137

vancouverense, Ptychoceras, II/38, 165 varagurense, Gaudryceras, II/144

Varunaites, II/148

venustum, Hyphantoceras, II/158

vertebralis, Baculites, I/111, 159, 165

vertebralis var. syriacus, Baculites, $\mathrm{I} / 160$

Vertebrites, II/141, 142, 145

voyanum, Kossmaticeras (Madrasites), II $/ 64$

voyi, Desmoceras (Desmoceras), II/6

waringi, Puzosia (Parapuzosia), II/64

warreni, Scaphites, II/171

whitei, Acanthoceras, II/82; 22, 1; 39, 1

willgreeni, Eupachydiscus, II/62

woodsi, Bostrychoceras, II/159

woodsi, Submortoniceras, II/125

wooldridgei, Graysonites, II/66; 18, 1

woollgari, Collignoniceras, II/105, 111, 117

wyomingensis, Prionocyclus, II/117

yamashitai, Anagaudryceras, II/138; 37,

1

yokoyamai, Anagaudryceras, II/139, 140

yokoyamai, Baculites, I/116, 124, 163

yokoyamai, Canadoceras, II/56; 12, 1;

$13,1,2 ; 14,1 ; 15,1$

Yokoyamaoceras, II/65

yoloensis, Desmophyllites, II/10

Yubariceras, II/86, 97

Zelandites, II/148

Zelandites sp., II/148

\section{Index of Formational Names}

described or mentioned in Notes on Stratigraphy

Antelope shale, III/31, 35, 36

Baker Canyon member, III/64

Benito sandstone, III $/ 42$

Brown Mountain sandstone, III/59

Carnerado conglomerate, III/42

Chico formation, III/13

Chignik formation, III/33

Ciervo shale, III $/ 42$

Corsicana marl, III/44

Debris Dam sandstone, III/69

Dosados sand and shale (member), III/ 44

Dos Palos shale (member), III/44
Forbes shale (formation), III/32, 33, 39

Funks shale (formation), III/31, 32, 34, 39

Franciscan group, III/70

Garzas sand (member), III/50, 53

Gualala group, III/73

Guinda sandstone (formation), III/ 31 , 33,34

Holz shale (member), III/65

Hornbrook formation, III/2

Horsetown group, III/30

Joaquin Ridge formation, III/60

Ladd formation, III/64

* Read Parapachydiscus catarinae for Pachydiscus catarinae on line 29, p. 155 of Part II. Read D. tenuisulcatum for D. tenuisulcatus on line 13, p. 165 of Part II. 
Llanada sandstone, III/42

Marca shale (member), III/44

Marlife formation, III/42

Matanuska formation, III/33

Moreno (shale) formation, III/44, 59, 61

Mustang shale (member), III/50, 52

Ono formation, III/26

Ortigalita sandstone, III/42

Pachydiscus silt, III/58

Panoche group, III/41

Papanatas conglomerate, III/41

Pleasants sandstone, III/66

Prairie Bluff chalk, III/44

Quinto silt (member), III/50, 52

Ragged Valley shale, III/58, 60

Redding formation, III/4
Redil formation, III/41

Rosario formation, III/69, 74

Schulz conglomerate, III/ 66

Sites sandstone (formation), III/31, 32, 34,39

Tierra Loma shale (member), III/44

Trabuco formation, III/64

Uhalde formation, III/43

Valudayur beds, III/46

Venado sandstone (formation), III/31, 37

Volta sand (member), III/50

Waltham shale, III/56

Wisenor formation, III/45

Williams formation, III/66

Yolo shale (formation), III/31, 34, 39

\title{
Index of Geographic Names
}

\author{
mentioned in Notes on Stratigraphy
}

Alcalde Hills, III/57

Alcatraz island, III/70

Antioch, III $/ 71$ (footnote)

Arroyo del Valle, III/71

Basin Hollow Creek, III/9

Battle Creek, III/20

Bear Creek, III/1

Benicia, III $/ 73$

Berkeley Hills, III/70

Bird Rock, III/70

Black Mountain, III/61

Briones Creek, III/73

Buckeye Creek, III/33

Butte Creek, III/19

Byron, III/73

Cedar Canyon, III/63

Chico Creek, III/13-19

Clover Creek, III/9

Coalinga, III/55

Coalinga Hot Springs Canyon, III/56

Coastal Region, III/73-74

Cottonwood Creek, III/22

Cottonwood Creek, Middle Fork, III/27

Cottonwood Creek, North Fork, III/22

Covelo, III/74

Crow Creek, III/54

Curry Creek [Canada], III/70

Curry Mountain, III/56

Dark Hollow, III/2

Dayton Canyon, III/68
Dry Creek (Shasta County), III/6

Dry Creek (Tehama County), III/27

El Toro, III/66

Enos Canyon, III/39

FITch ranch, III/2

Forty-nine Mine, III/2

Fruto, III/34

Garzas Creek, III/50

Folsom, III/21

Golden Gate, III/70

Gualala, III/73

Henley, III/2

Hornbrook, III/2

Hornbrook-Yreka area, III/1-3

Horsetown, III/29

Hospital Canyon [Creek], III $/ 53$

Huling [Hulen] Creek, III/22

Ingram Creek, III/54

Joaquin Rocks, III/59

Juniper Ridge, III/56

La Jolla, III/ 69

Little Chico Creek, III/19

Little Cow Creek, III/4

Little Salado Creek, III/54, 55

Lodoga, III/34

Logan Ridge, III/34

Logan Ridge-Sites area, III/34-37

Long Canyon, III/56

Los Banos Creek, III/49

Los Gatos Creek, III/57-59 
Martinez, III/73

Marysville Buttes, III/21

Mill Creek, III/20

Milton, III $/ 21$

Montague, III $/ 3$

Mt. Boardman, III $/ 54$

Mt. Diablo, III/70, 73

New Idria, III/55, 61

Nigger Heaven, III/33

Oak Run, III /9

Old Cow Creek, III/9

Ono, III $/ 22$

Ono area, III/22-31

Orestimba-Carbona area, III/53-55

Orestimba Creek, III/53

Ortigalita Creek, III/46

Ortigalita Peak area, III/45-50

Pacheco Pass, III/50

Pacheco Pass area, III/50-53

Panoche Hills, III/40-45

Pape Place, III/20

Parsons Canyon, III/57

Pentz, III/20

Peterson ranch, III/34

Pleasants Valley, III/40

Phoenix (Oregon), III/2

Point Loma, III/69

Pt. Conception, III/69

Puerto Creek, III/53

Putah Creek, III/37

Quinto Creek, III/50

Redding, III/3, 29

Redding area, III/3-12

Redmont cut, III/71

Reef Ridge, III/62

RICHARDSON ranch, III/3

Roaring River, III/26

Rock Corral, III/21

Rocky Gulch, III/2

Rumsey Hills-Cache Creek area, III/32-
34

Sacramento Valley east side, III/12-22

northeast side, III/3-12

northwest side, III/22-31

west side, III/31-40

Salt Creek (Colusa County), III/33

Salt Creek (Merced County), III/49

San Francisco Bay area, III/69-73

San Joaquin Valley west side, III/40-63

San Luis Gonzaga, III/51

Sand Creek, III/33

Santa Ana Mountains, III/63-67

Santa Monica Mountains, III/67

Santa Ynez Mountains, III/69

ScotT ranch, III/40

Simi Hills, III/68

Shale Hills, III/63

Sites, III $/ 35$

Slate Hot Springs, III/74

SMITH ranch, III $/ 2$

South Cow Creek, III/10

Stanford, III/73

Stony Creek, III/36

Sutter Buttes, III/21

Swede Creek, III/7

Temblor Range, III/63

Tesla, III/71

Texas Flat, III/21

Texas Springs, III/30

Topanga Canyon, III/67

Trach ranch, III/21

Tracy, III/55

Volta, III $/ 49$

Walthan Creek, III/55-57

Wheeler Gorge, III/69

Wilcox Ridge, III/53

Wildcat Canyon, III/46

Willow Creek, III/36 


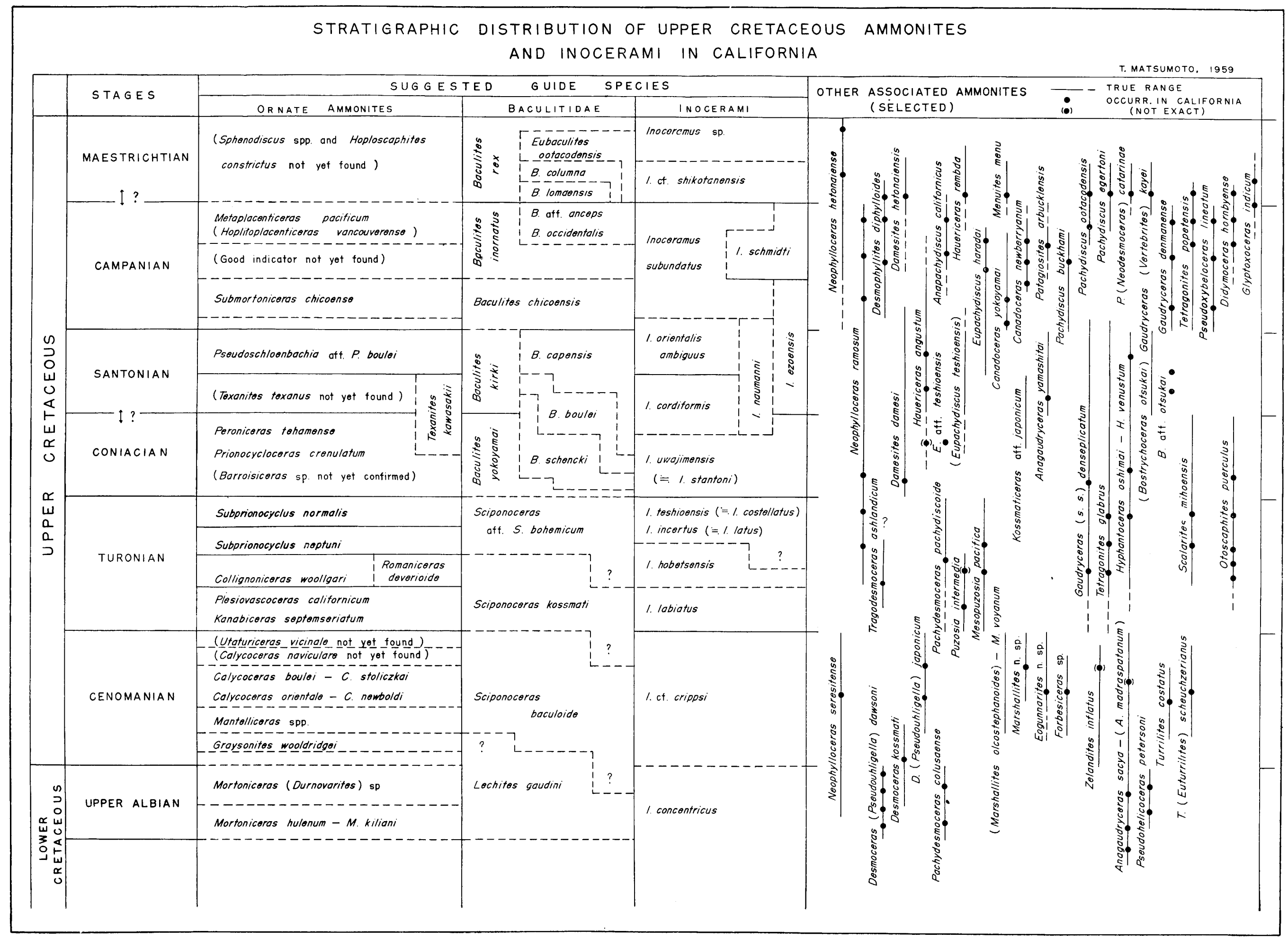

See p. $175-180$ for further details. 


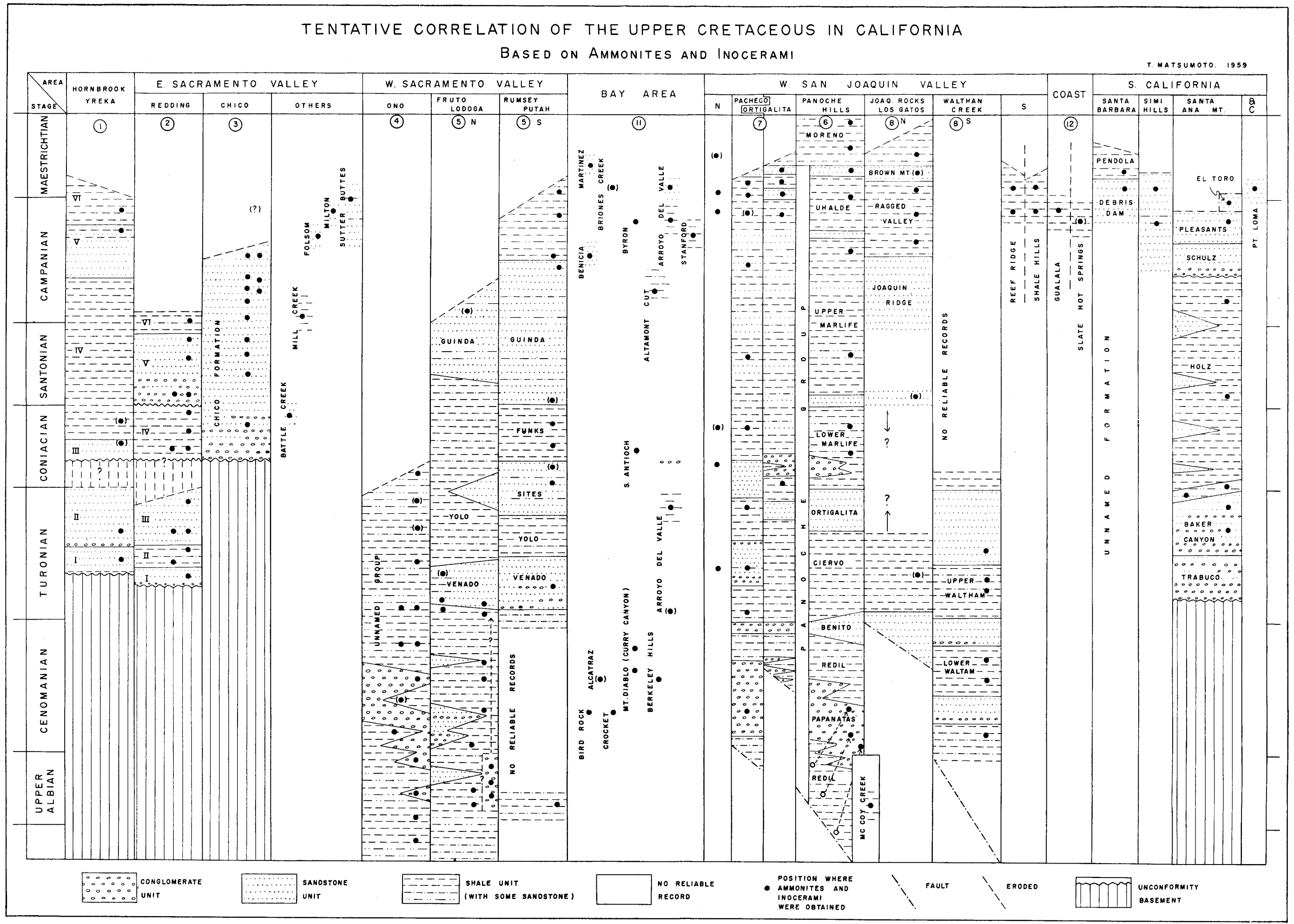

See p. 180-181 and p. 1-74 [Notes on Stratigraphy] for further details. (Read Lower WALTHAM for Lower WaLtam [in the 7 th right column], (9) and (10) for blank below SANTA ANa Mt. [2 nd right column] and Simi Hills \& SANTA BARBARA [3 rd and 4 th right columns].) 